VILNIAUS GEDIMINO TECHNIKOS UNIVERSITETAS

Andrius KATKEVIČIUS

\title{
SPIRALINIŲ IR MEANDRINIŲ LĖTINIMO SISTEMŲ DAŽNINIŲ SAVYBIŲ TYRIMAS
}

DAKTARO DISERTACIJA

TECHNOLOGIJOS MOKSLAI,

ELEKTROS IR ELEKTRONIKOS INŽINERIJA (01T)

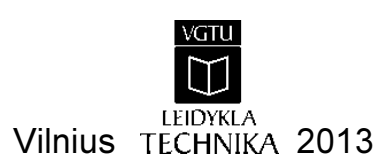


Disertacija rengta 2009-2013 metais Vilniaus Gedimino technikos universitete.

\section{Mokslinis vadovas}

prof. habil. dr. Stanislovas ŠTARAS (Vilniaus Gedimino technikos universitetas, technologijos mokslai, elektros ir elektronikos inžinerija - 01T, 2009-2011).

prof. habil. dr. Romanas MARTAVIČIUS (Vilniaus Gedimino technikos universitetas, technologijos mokslai, elektros ir elektronikos inžinerija - 01T, 2011-2013).

VGTU leidyklos TECHNIKA 2130-M mokslo literatūros knyga http://leidykla.vgtu.lt

ISBN 978-609-457-493-1

(C) VGTU leidykla TECHNIKA, 2013

(C) Andrius Katkevičius, 2013

andrius.katkevicius@vgtu.lt 
VILNIUS GEDIMINAS TECHNICAL UNIVERSITY

Andrius KATKEVIČIUS

\section{INVESTIGATION OF FREQUENCY PROPERTIES OF HELICAL AND MEANDER SLOW-WAVE SYSTEMS}

DOCTORAL DISSERTATION

TECHNOLOGICAL SCIENCES,

ELECTRICAL AND ELECTRONIC ENGINEERING (01T)

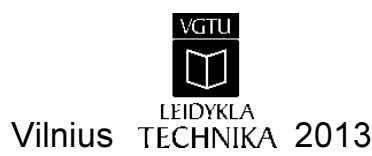


Doctoral dissertation was prepared at Vilnius Gediminas Technical University in 2009-2013.

\section{Scientific Supervisor}

Prof Dr Habil Stanislovas ŠTARAS (Vilnius Gediminas Technical University, Technological Sciences, Electrical and Electronic Engineering-01T, 2009-2011).

Prof Dr Habil Romanas MARTAVIČIUS (Vilnius Gediminas Technical University, Technological Sciences, Electrical and Electronic Engineering 01T, 2011-2013). 


\section{Reziumè}

Disertacijoje sprendžiama spiralinių ir meandrinių lètinimo sistemų su periodiniais netolygumais modeliavimo metodų tobulinimo ir jų tobulesnių konstrukcijų paieškos problema. Pagrindiniai tyrimo objektai - nevienalytès periodinès lètinimo sistemos ir ju modeliai bei analizès metodai. Darbo tikslas yra tobulinti sudetingas turinčias periodinių netolygumų spiralines ir meandrines lètinimo sistemas ir ištirti jų analizès metodus, siekiant atskleisti nevienalyčių lètinimo sistemų savybes ir jų automatizuoto projektavimo galimybes.

Darbe sprendžiami uždaviniai: periodinių netolygumu įtakos nevienalyčių lètinimo sistemų savybèms tyrimas; spiralinių, meandrinių ir hibridinių lètinimo sistemų, turinčiu periodinių netolygumų, savybių tyrimas; lètinimo sistemų automatizuotos analizès ir projektavimo algoritmų kūrimas, taikant dirbtinių neuronų tinklus.

Disertaciją sudaro įvadas, keturi skyriai, bendrosios išvados, naudotos literatūros ir autoriaus publikacijų disertacijos tema sąrašai ir 2 priedai.

Ivadiniame skyriuje formuluojama tiriamoji problema, aptariamas darbo aktualumas, aprašomas tyrimų objektas, formuluojamas darbo tikslas bei uždaviniai, aprašoma tyrimu metodika, darbo mokslinis naujumas, rezultatų praktiné reikšmè, ginamieji teiginiai. İvado pabaigoje pristatomi pranešimai konferencijose disertacijos tema bei pateikiama disertacijos struktūra.

Pirmajame skyriuje pateikiama literatūros analizè, aptariamos lètinimo sistemų taikymo sritys. Analizuojama lètinimo sistemų periodinių netolygumų problema. Aptariamas autoriaus indèlis i nagrinèjamos problemos sprendimą. Skyriaus pabaigoje formuluojamos išvados ir tikslinami disertacijos uždaviniai.

Antrajame skyriuje parinktos ilgosios linijos iejjimo varžos bei perdavimo koeficiento dažninių charakteristikų skaičiavimo metodikos, aptartos sudarytos programos ir pateikti tyrimo rezultatai, atskleidžiantys nevienalytiškumo įtaką lètinimo sistemų savybèms.

Trečiajame skyriuje tiriamos turinčios periodinių netolygumų spiralinès, meandrinès ir hibridinès lètinimo sistemos. Parenkamos sistemos įejjimo varžos, lètinimo koeficiento ir užtvarinès juostos pločio skaičiavimo metodikos bei pateikiami jų tyrimo rezultatai.

Ketvirtajame skyriuje parodomos galimybès automatizuotam lètinimo sistemų projektavimui taikyti dirbtinių neuronų tinklus bei pateikiami lètinimo sistemų tyrimo, taikant dirbtinių neuronų tinklus, rezultatai.

Disertacijos tema paskelbti 9 moksliniai straipsniai, iš kurių šeši recenzuojamuose mokslo žurnaluose. Keturi iš jų mokslo žurnaluose, įtrauktuose ị Thomson Reuters Web of Science duomenų bazę. Disertacijos tema perskaityta vienuolika pranešimų mokslinėse konferencijose. 


\section{Abstract}

There are investigated issues of modeling techniques improvement and investigation of improved design of helical and meander slow-wave systems with periodical inhomogeneities in the dissertation. Objects of research - models of slow-wave systems with periodical inhomogeneities and their methods of investigation. Aim of the work - improvement of sophisticated helical and meander slow-wave systems with periodical inhomogeneities and investigation of their methods of analysis, in order to reveal general characteristics of inhomogeneous slow-wave systems and capabilities of using computer-aided design.

The dissertation approaches major tasks such as: influence of periodical inhomogeneities to characteristics of slow-wave systems; investigation of properties of helical, meander and hybrid slow-wave systems with periodical inhomogeneities; creation of automated algorithms of analysis and design of slow-wave systems using artificial neural networks.

The thesis consists of four parts including introduction, 4 chapters, conclusions, references and 2 annexes.

The introduction reveals investigated problem, importance of the thesis and object of research. It also describes the purpose and tasks of the dissertation, research methodology, scientific novelty, the practical significance of results examined in the thesis and defended statements. The introduction ends in presenting the author's publications on the subject of the defended dissertation, offering the material of made presentations in conferences and defining the structure of the dissertation.

Chapter 1 revises used literature. At the end of the chapter conclusions are drawn and the tasks for the dissertation are reconsidered.

Chapter 2 describes the methodology for calculation of input impedance and transfer coefficient characteristics of the transmission line and investigation of their methods of analysis.

Chapters 3 investigates helical, meander and hybrid slow-wave systems with periodical inhomogeneities. Methodologies for calculation input impedance, retardation factor and the stop-band width are selected.

In the chapters 4 are discussed the findings of research and are proven possibilities to use artificial neural networks in automated computer-added design of slow-wave systems.

9 articles focusing on the subject of the discussed dissertation are published: six articles in reviewed scientific journals, four of them in Thomson Reuters Web of Science register, tree articles - in conference proceedings. 11 presentations on the subject have been given in conferences on national and international level. 


\section{Žymèjimai}

\section{Simboliai}

a - koeficientas, matmuo;

$b$ - koeficientas, matmuo;

C - talpa, kontūras;

c - koeficientas, matmuo;

$\mathrm{c}_{0} \quad$ šviesos greitis;

E - elektrinio lauko stiprumas (stipris), šaltinio elektrovara;

$f \quad$ - dažnis;

$f_{\mathrm{c}} \quad$-užtvarinès juostos centrinis dažnis;

$g$ - funkcija;

$h$ - impulsinè charakteristika, matmuo, poslinkis;

I - srovès stipris;

$i \quad-$ momentinis srovès stipris, eilès numeris;

$j \quad$ - eilès numeris;

j - menamasis vienetas;

$K$ - perdavimo funkcija;

$K(\omega)$ - dažninè amplitudès charakteristika; 
$k-$ bangos skaičius, eilès numeris;

$k_{\mathrm{L}}-$ lètinimo koeficientas;

$L \quad$ - žingsnis, kontūras;

$L_{\mathrm{H}} \quad$ induktyvumas;

$L_{\mathrm{S}} \quad$ - lètinimo sistemos ilgis;

$l_{i} \quad-i$-osios srities ilgis;

$l_{\mathrm{p}} \quad$ - linijos nevienalyčio periodo ilgis;

$m$ - eilès numeris;

$N$ - sveikasis skaičius;

$n$ - eilès numeris;

$p \quad$ - atspindžio koeficientas;

$R \quad$ - aktyvioji varža;

$S$ - plotas, matmuo;

$s \quad$ - signalas, matmuo;

$T$ - periodas;

$T(t)$ - pereinamoji charakteristika;

$t$ - laikas;

$t_{\mathrm{v}} \quad$ - vèlinimo trukme;

$U$ - potencialu skirtumas, itampa;

$u$ - momentinè įtampa;

$v_{\mathrm{f}} \quad$ - fazinis greitis;

$w$ - matmuo;

$x$ - koordinate;

$Y$ - laidumas;

$y$ - koordinate;

$Z-$ varža;

$Z_{\mathrm{B}}$ - banginè varža;

$Z_{\mathrm{IN}}-$ ìjjimo varža;

$Z_{\mathrm{a}} \quad$ - apkrovos varža;

$z$ - koordinate;

$\alpha \quad$ koeficientas, daugiklis, slopinimo koeficientas;

$\beta$ - fazès koeficientas;

$\Delta \quad$ - pokytis, žingsnis;

$\Delta F$ - praleidžiamujų dažnių juostos plotis; 
$\varepsilon_{\mathrm{r}} \quad$-santykinė dielektrinè skvarba;

$\varepsilon_{0} \quad$ - elektrinè konstanta;

$\lambda$ - bangos ilgis;

$\mu_{\mathrm{r}} \quad$ - santykinė magnetinè skvarba;

$\mu_{0}$ - magnetinè konstanta;

$\tau \quad$ - laiko pastovioji;

$\theta \quad$ - fazès skirtumo kampas;

$\omega \quad$ - kampinis dažnis;

$\boldsymbol{Y}$ - normuotujų laidžių sklaidos matrica;

$\boldsymbol{Z}$ - normuotujų varžų sklaidos matrica;

$\boldsymbol{B}-\beta$ parametrų sklaidos matrica;

$\boldsymbol{H}-h$ parametrų sklaidos matrica.

\section{Santrumpos}

LS - lètinimo sistema;

SLS - spiralinè lètinimo sistema;

MLS - meandrinè lètinimo sistema;

HLS - hibridinè lètinimo sistema;

BBEVS - bėgančios bangos elektroninių vamzdžiu sistemos;

KKGS - kietojo kūno galios stiprintuvas;

FDM - baigtinių skirtumų metodas;

FEM - baigtinių elementu metodas;

FDTD - baigtinių skirtumų laiko srities metodas;

MoM - momentų metodas;

DNT - dirbtiniu neuronų tinklas;

PIP - programinès ịrangos paketas. 



\section{Turinys}

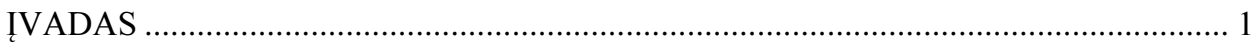

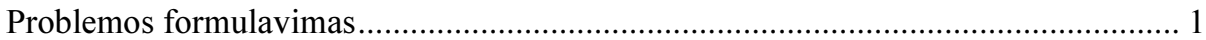

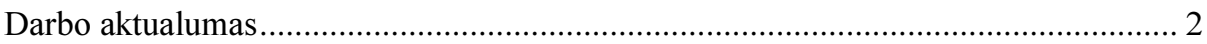

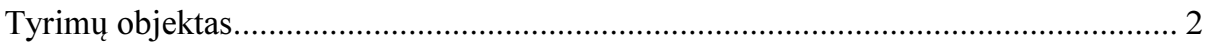

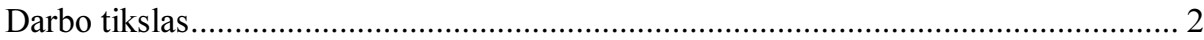

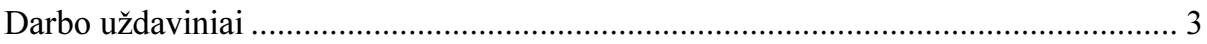

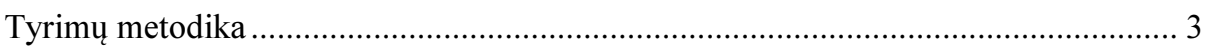

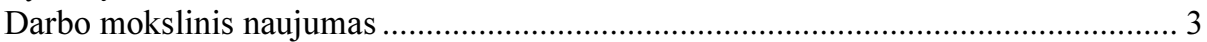

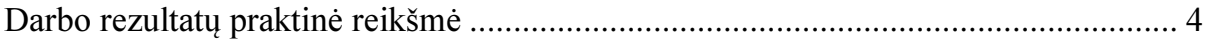

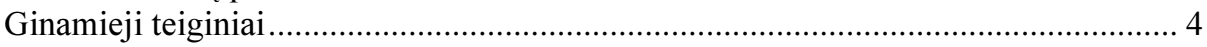

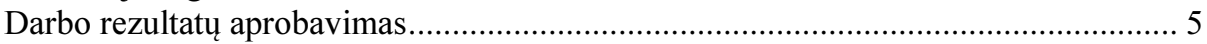

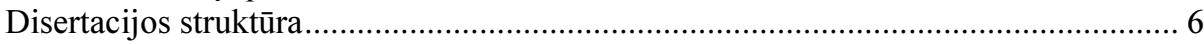

1. NEVIENALYČIŲ LĖTINIMO SISTEMŲ IR JŲ ANALIZĖS METODŲ

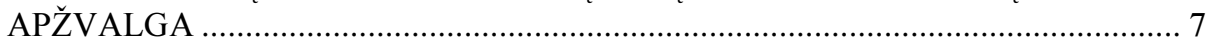

1.1. Nevienalyčių lètinimo sistemų modeliai ir tyrimas .............................................. 7

1.2. Nevienalyčių lètinimo sistemų taikymo sritys.................................................... 10

1.2.1. Spiralinès konstrukcijos lètinimo sistemų taikymo sritys............................. 10

1.2.2. Meandrinès konstrukcijos lètinimo sistemų taikymo sritys ........................... 13

1.3. Nevienalyčiu lètinimo sistemų tyrimams taikomi metodai .................................. 19

1.4. Nevienalyčių lètinimo sistemų problemos ...................................................... 22

1.5. Nevienalyčių lètinimo sistemų tyrimas taikant dirbtinių neuronų tinklus ............ 23 


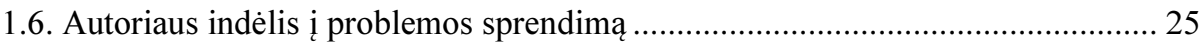

1.7. Pirmojo skyriaus išvados ir disertacijos uždavinių formulavimas........................ 26

2. NEVIENALYČIŲ PERIODINIŲ SISTEMŲ SAVYBIŲ TYRIMAS ......................... 27

2.1. Sistemų dažninių savybių tyrimas ilgujų linijų metodu....................................... 27

2.1.1. İejimo varžos skaičiavimo algoritmas ...................................................... 28

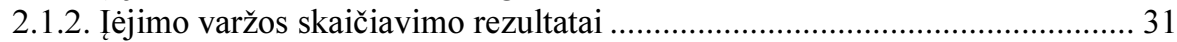

2.2. Sistemų dažninių savybių tyrimas matricų metodu ............................................. 35

2.2.1. Skaičiavimų algoritmas matricų metodu ................................................... 35

2.2.2. Skaičiavimų rezultatai matricų metodu ....................................................... 38

2.3. Periodinių netolygumų itaka pereinamajai charakteristikai................................ 44

2.3.1. Pereinamosios charakteristikos ir impulsinių signalų formos tyrimai .......... 44

2.3.2. Pereinamosios charakteristikos ir impulsinių signalų skaičiavimo

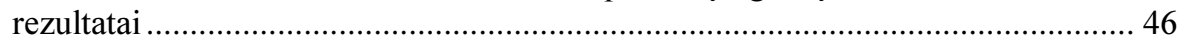

2.4. Sistemų tyrimas taikant specializuotą programinę įrangą ................................... 48

2.4.1. Nevienalyčių periodinių sistemų tyrimo modeliai......................................... 48

2.4.2. Nevienalyčių periodinių sistemų modeliavimo rezultatai............................... 50

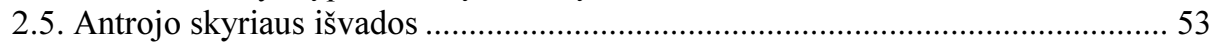

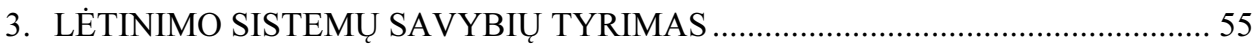

3.1. Spiralinès konstrukcijos lètinimo sistemos modelis ir savybių analizė ................ 56

3.1.1. Spiralinès konstrukcijos lètinimo sistemos modelis ..................................... 56

3.1.2. Spiralinès konstrukcijos lètinimo sistemos savybių analizè ........................... 62

3.2. Meandrinès konstrukcijos lètinimo sistemos modelis ir savybių analizė ............ 67

3.2.1. Meandrinès konstrukcijos lètinimo sistemos modelis ................................... 67

3.2.2. Meandrinès konstrukcijos lètinimo sistemos savybių analizè ....................... 69

3.3. Hibridinès konstrukcijos lètinimo sistemos modelis ir savybių analizè .............. 74

3.3.1. Hibridinès konstrukcijos lètinimo sistemos modelis ..................................... 74

3.3.2. Hibridinès konstrukcijos lètinimo sistemos savybių analizè ......................... 76

3.4. Lètinimo sistemų tyrimas taikant specializuotą programinę įrangą ..................... 77

3.4.1. Nevienalyčių lètinimo sistemų tyrimo modeliai .............................................. 77

3.4.2. Nevienalyčių lètinimo sistemų tyrimo rezultatai .......................................... 81

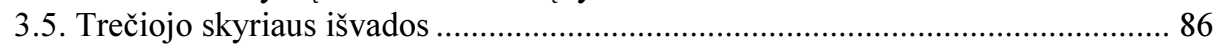

4. LĖTINIMO SISTEMŲ TYRIMAS TAIKANT DIRBTINIŲ NEURONŲ

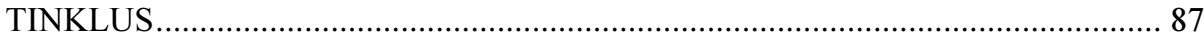

4.1. Prognozès algoritmai taikant dirbtinių neuronų tinklus..................................... 87

4.1.1. Dirbtinių neuronų tinklų taikymo galimybių analizė..................................... 88

4.1.2. Analizès ir projektavimo algoritmai taikant dirbtinių neuronų tinklus......... 91

4.2. Prognozès rezultatai taikant dirbtinių neuronų tinklus ........................................ 95

4.2.1. Analizès rezultatai taikant dirbtinių neuronų tinklus .................................... 95

4.2.2. Projektavimo rezultatai taikant dirbtinių neuronų tinklus ............................ 100

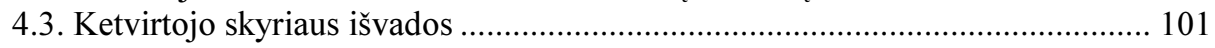

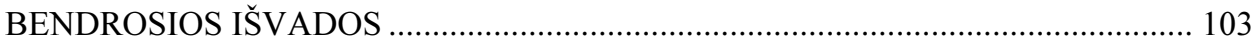




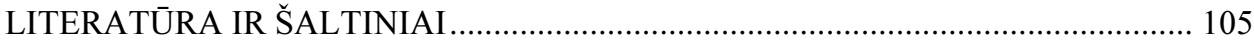

AUTORIAUS PUBLIKACIJŲ DISERTACIJOS TEMA SĄRAŠAS …....................... 115

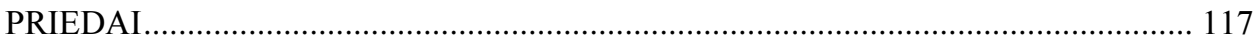

A priedas. Eksperimentinès sistemos struktūrinè schema ........................................ 117

B priedas. Meandrinès lètinimo sistemos eksperimento rezultatai ............................ 118 



\section{Contents}

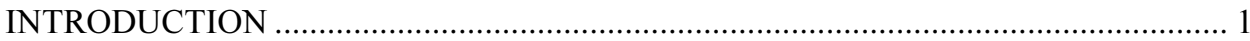

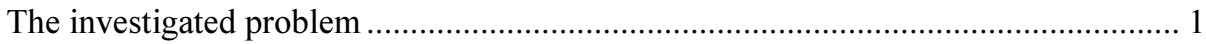

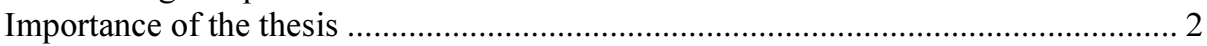

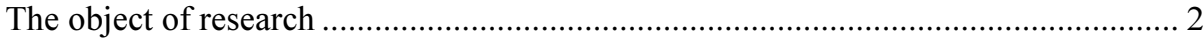

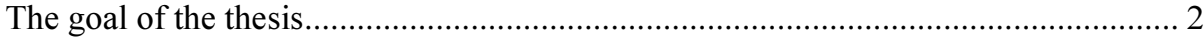

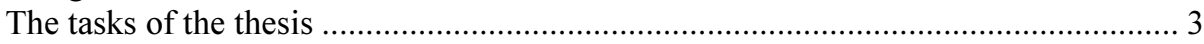

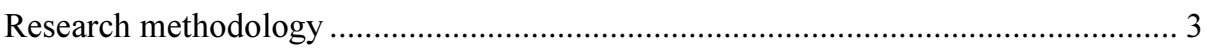

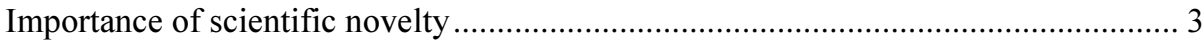

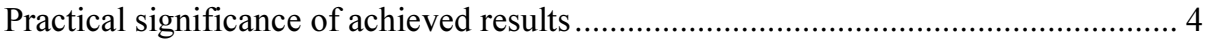

The defended propositions ...................................................................................... 4

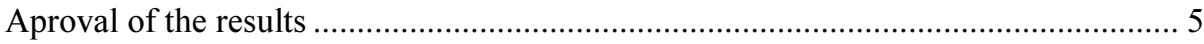

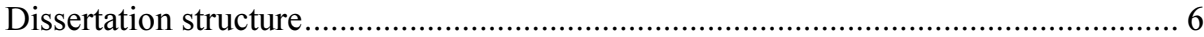

1. REVIEW OF INHOMOGENEOUS SLOW-WAVE SYSTEMS AND THEIR

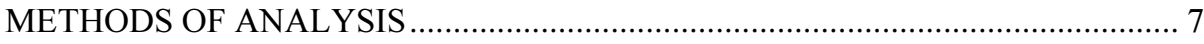

1.1. Models and analysis of inhomogeneous slow-wave systems ............................... 7

1.2. Scope of applications of inhomogeneous slow-wave systems ............................ 10

1.2.1. Application areas of helical slow-wave systems ........................................ 10

1.2.2. Application areas of meander slow-wave systems ...................................... 13

1.3. Methods applying to investigations of inhomogeneous slow-wave systems....... 19

1.4. Applications problems of inhomogeneous slow-wave systems .......................... 22 
1.5. Investigation of inhomogeneous slow-wave systems using artificial neural networks

1.6. Author's contribution to the solution of the problem.......................................... 25

1.7. Conclusions of the chapter 1 and formulation of thesis tasks.............................. 26

2. INVESTIGATION OF PROPERTIES OF INHOMOGENEOUS PERIODICAL SYSTEMS

2.1. The investigation of system frequency characteristics using transmission lines method 27

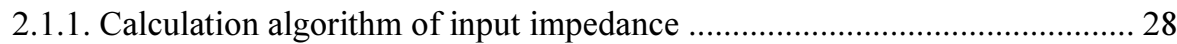

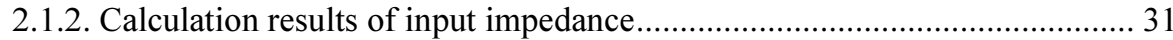

2.2. The investigation of system frequency characteristics using matrix method ...... 35

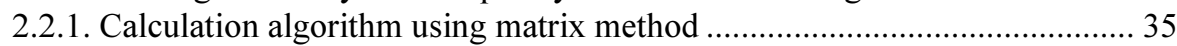

2.2.2. Results of calculations using matrix method .................................................. 38

2.3. Influence of periodical inhomogeneities on transient responses ......................... 44

2.3.1. Investigations of transient responses and pulse waveforms .......................... 44

2.3.2. Calculation results of transient responses and the pulse signals ................... 46

2.4. Systems investigation using specialized software packages.............................. 48

2.4.1. Investigation methods of inhomogeneous periodical systems ...................... 48

2.4.2. Results of modeling of inhomogeneous periodical systems ......................... 50

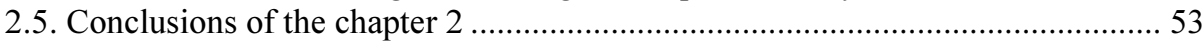

3. INVESTIGATION OF PROPERTIES OF SLOW-WAVE SYSTEMS ……..............55

3.1. Model and the analysis of properties of helical slow-wave system ..................... 56

3.1.1. The model of helical slow-wave system.................................................... 56

3.1.2. Analysis of properties of helical slow-wave system..................................... 62

3.2. Model and the analysis of properties of meander slow-wave system................. 67

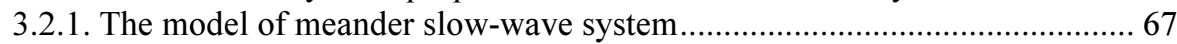

3.2.2. Analysis of properties of meander slow-wave system.................................... 69

3.3. Model and the analysis of properties of hybrid slow-wave system ..................... 74

3.3.1. The model of hybrid slow-wave system .................................................... 74

3.3.2. Analysis of properties of hybrid slow-wave system ................................... 76

3.4. Investigation of slow-wave systems using specialized software packages.......... 77

3.4.1. Investigation models of inhomogeneous slow wave systems ........................ 77

3.4.2. Investigation results of inhomogeneous slow wave systems ......................... 81

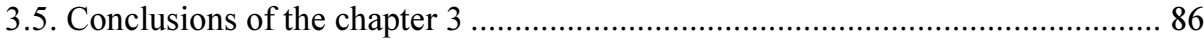

4. INVESTIGATION AND DESIGN OF THE SLOW-WAVE SYSTEMS USING

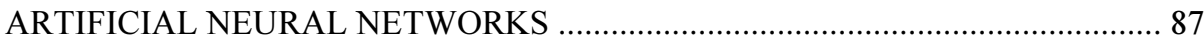

4.1. Prediction algorithms using artificial neural networks ...................................... 87

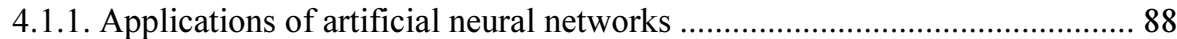

4.1.2. Analysis and synthesis algorithms using artificial neural networks .............91

4.2. Prediction results using artificial neural networks............................................ 95

4.2.1. Analysis results using artificial neural networks ....................................... 95

4.2.2. Synthesis results using artificial neural networks ..................................... 100 
4.3. Conclusions of the chapter 4

GENERAL CONCLUSIONS

REFERENCES 105

LIST OF THE AUTHOR'S SCIENTIFIC PUBLICATIONS RELATED TO THE

APPENDIXES

Appendix A. Structural diagram of experimental system 117

Appendix B. Results of the experiment of meander slow-wave system. 118 



\section{Ivadas}

\section{Problemos formulavimas}

Dèl susidarančių spiralinėse ir meandrinèse lètinimo sistemų konstrukcijose periodinių netolygumų jos igauna nepageidaujamas užtvarinių filtrų savybes, dèl ko mažèja viso elektrodinaminio ịtaiso praleidžiamuju dažnių juostos plotis. Siekiant pagerinti elektrinių ịtaisu dažnines savybes reikia ieškoti tobulesnių spiralinių ir meandrinių lètinimo sistemų konstrukcijų, leisiančių praplèsti praleidžiamųjų dažnių juostą ir sumažinti dažninių charakteristikų kitimus.

Spiralinių ir meandrinių lètinimo sistemų analizei dažniausiai taikomi analitiniai ir skaitiniai iteraciniai analizès metodai, leidžiantys apskaičiuoti jų elektrinius parametrus ir charakteristikas. Šie metodai reikalauja didelių skaičiavimo resursų, sudètingų matematinių modelių sudarymo bei negali kaupti projektuotojo patirties. Ieškant naujų lètinimo sistemų konstrukcijų, reikia tobulinti lètinimo sistemų modeliavimo metodus.

Disertacijoje sprendžiama spiralinių ir meandrinių lètinimo sistemų su periodiniais netolygumais modeliavimo metodų tobulinimo ir jų tobulesnių konstrukcijų paieškos problema. 


\section{Darbo aktualumas}

Spiralinès ir meandrinès konstrukcijos lètinimo sistemos plačiai naudojamos šiuolaikinèse elektroninėse sistemose ir ịtaisuose: antenose, filtruose, šakotuvuose, monolitiniuose integriniuose grandynuose, didelio duomenų perdavimo greičio skaitmeniniuose itaisuose ir pan.

$\mathrm{XX}$ a. viduryje letinimo sistemos buvo projektuojamos taikant eksperimentinius ir analitinius metodus. Vystantis kompiuterinei technikai ir išryškejjus analitinių metodų apribojimams dèl sudètingo matematinio modelio aprašymo plačiau pradèti taikyti skaitiniai metodai. Taikant skaitinius metodus skaičiavimai analizuojant praktikoje taikomus įtaisus gali trukti daug valandu net naudojant pajègias darbo stotis. Nuo XX a. dešimto dešimtmečio vidurio taikomos technologijos, leidžiančios išlygiagretinti skaičiavimus tarp asmeninių kompiuterių arba grafinių bei specialios paskirties mikroprocesorių. Pastaraisiais metais dirbtinių neuronų tinklų metodai buvo pripažinta kaip naudinga alternatyva tradiciniams mikrobangų modeliavimo metodams.

Spiralinès ir meandrinès lètinimo sistemų konstrukcijos dèl periodiškai kintančių vienalyčių sričių ir nuo jų susidarančių atspindžių igauna nepageidaujamas užtvarinių filtru savybes. Dèl šios priežasties didèja lètinimo koeficiento dažninių charakteristikų dispersija ir siaurejja lètinimo sistemos ir viso ịtaiso darbo dažnių sritis. Todèl tikslinga ieškoti naujų lètinimo sistemų konstrukcijų, leisiančių praplèsti darbo dažnių sriti bei sumažinti lètinimo koeficiento dispersiją.

Taigi aktualu ieškoti naujų automatizuoto lètinimo sistemų tyrimo metodų, taikant dirbtinių neuronų tinklus, leisiančių surasti lètinimo sistemų parametrus, išvengiant sudètingų lètinimo sistemų matematinių modelių sudarymo, pagreitinti skaičiavimus, išvengiant papildomos brangios įrangos naudojimo, ir išsaugoti sukauptas lètinimo sistemų projektavimo žinias.

\section{Tyrimų objektas}

Darbo tyrimų objektas - nevienalytès periodinès lètinimo sistemos ir jų modeliai bei analizès ir sintezès metodai.

\section{Darbo tikslas}

Darbo tikslas yra tobulinti sudètingas turinčias periodinių netolygumų elektrodinamines spiralines ir meandrines lètinimo sistemas bei ištirti jų analizès metodus, siekiant atskleisti nevienalyčių lètinimo sistemų ypatumus ir jų automatizuoto projektavimo galimybes. 


\section{Darbo uždaviniai}

Darbo tikslui pasiekti darbe reikia spręsti šiuos uždavinius:

1. Ištirti periodinių netolygumų įtaką nevienalyčių lètinimo sistemų savybèms.

2. Ištirti spiralinių, meandrinių ir hibridinių lètinimo sistemų, turinčių periodinių netolygumų, savybes.

3. Taikant dirbtinių neuronų tinklus sudaryti turinčių periodinių netolygumų lètinimo sistemų automatizuotos analizès ir projektavimo algoritmus.

4. Imitacinių skaičiavimų būdu patikrinti siūlomų metodų veiksmingumą.

\section{Tyrimų metodika}

Darbe taikomi elektrodinaminio uždavinio sprendimo metodai, pritaikyti lètinimo sistemų analizei - tai ilgụų linijų, matricinis, daugialaidžių linijų ir skaitinis metodai, dirbtinių neuronų tinklų teorija. Lètinimo sistemų kompiuteriniai modeliai ir sukurtieji algoritmai igyvendinti, taikant programų paketą Matlab ${ }^{\circledR}$ bei specialios paskirties programų paketus CST Microwave Studio ${ }^{\circledR}$ ir Sonnet ${ }^{\circledR}$.

\section{Darbo mokslinis naujumas}

Rengiant disertaciją buvo gauti šie elektros ir elektronikos inžinerijos mokslui nauji rezultatai:

1. Sukurti nauji ilgosios linijos su periodiniais netolygumais modeliai bei metodai nevienalyčių plačiajuosčių periodinių sistemų užtvarinėms savybèms tirti bei gauti jų tyrimo rezultatai.

2. Taikant daugialaidžių linijų metodą sukurti algoritmai, leidę ištirti lètinimo sistemos parametrų įtaką užtvarinès juostos pločiui, kurių rezultatai panaudoti spiralinių lètinimo sistemų projektavimui.

3. Sukurti meandrinès, spiralinès bei hibridinès spiralè-meandras-spiralè sistemų matematiniai modeliai ir išvestos dispersinès lygtys, leidusios atskleisti lètinimo sistemų periodinio nevienalytiškumo ir skersinio asimetriškumo įtaką sistemų dažninèms savybèms. 
4. Taikant dirbtinių neuronų tinklus sukurta nevienalyčių elektrodinaminių lètinimo sistemų dažninių charakteristikų skaičiavimo metodika, leidžianti nustatyti dažnines charakteristikas neišvedant sistemų dispersinių lygčių ir sudaryti dirbtinių neuronų tinklais paremti lètinimo sistemų automatizuoto projektavimo algoritmai.

\section{Darbo rezultatụ praktinè reikšmė}

Sudaryti elektrodinaminių lètinimo sistemų tyrimo metodai ir iteraciniai skaičiavimo algoritmai, leidžiantys projektuoti lettinimo sistemas, įvertinant sistemose esančius periodinius netolygumus, ir atskleisti naujausių konstrukcijų lètinimo sistemu ypatumus. Sudaryti dirbtinių neuronų tinklais paremti lètinimo sistemų dažninių charakteristikų skaičiavimo algoritmai, leidžiantys atsisakyti sudètingų analitinių metodų ir paspartinti analizès ir sintezès procesus. Naudojant programinị paketą Matlab ${ }^{\circledR}$ sudaryta programinè įranga, leidžianti projektuoti lètinimo sistemas.

\section{Ginamieji teiginiai}

1. Dèl periodinių netolygumų lètinimo sistemos įgauna užtvarinių filtrų savybes, to priežastimi yra atsiradęs fazių skirtumo kampas tarp gretimų laidininkų itampų ar srovių, siekiantis iki $\pi / 2$ arba $\pi$ radianų.

2. Turinčiu periodinių netolygumų lètinimo sistemų lètinimo koeficiento dažninės charakteristikos dispersiją pavyksta sumažinti ir išvengti užtvarinès juostos, mažinant banginių varžų kitimo santykị išilgai laidininko iki 1,3 ir didinant vienalyčių sričių ilgių santykị iki 1,5 bei mažinant nevienalytiškumo periodą, t. y. didinant nevienalyčių periodų skaičiu išilgai laidininko vijos.

3. Padidinti meandrinių lètinimo sistemų lètinimo koeficientą ir iejjimo varžą ir garantuoti didesnį sistemos jautrumą galima papildant sistemą spiraliniu laidininku - naudojant hibridinę spiralè-meandras-spiralè sistemą.

4. Dirbtinių neuronų tinklais paremti algoritmai leidžia taikyti automatizuotus nevienalyčių lètinimo sistemų projektavimo ir analizès metodus, neišvedant sistemų dispersinių lygčių. 


\section{Darbo rezultatų aprobavimas}

Disertacijos tema atspausdinti 9 moksliniai straipsniai, iš kurių 6 straipsniai paskelbti recenzuojamuose mokslo žurnaluose.

Disertacijos tema perskaityta 11 pranešimų mokslinėse konferencijose Lietuvoje ir užsienyje:

- Katkevičius, A. 2009. Linijų su periodiniai netolygumais dažninių charakteristikų tyrimas. Dvyliktoji respublikiné Lietuvos jaunujų mokslininkų konferencija „Mokslas - Lietuvos ateitis“. Vilnius, 2009 m. kovo $20 \mathrm{~d}$.

- Katkevičius, A., Štaras, S. 2009. Simulation of Structures Containing Periodical Inhomogeneities. XIX International Conference on Electromagnetic Disturbances „EMD2009“. Balstogé, Lenkija, 2009 m. rugsèjo $23-25 \mathrm{~d}$.

- Katkevičius, A. 2010. Linijos su nuostoliais bei periodiniais netolygumais savybių tyrimas. Tryliktoji respublikinè Lietuvos jaunujų mokslininku konferencija „Mokslas - Lietuvos ateitis“. Vilnius, 2010 m. kovo $19 \mathrm{~d}$.

- Katkevičius, A., Štaras, S. 2010. Properties of Helical Structures Containing Periodical Inhomogeneities. Keturioliktoji tarptautinè konferencija „Elektronika 2010“. Vilnius, $2010 \mathrm{~m}$. gegužès 18-20 d.

- Katkevičius, A., Štaras, S. 2010. Analysis of Helical Systems Containing Periodical Inhomogeneities. Aštuonioliktoji tarptautinė mikrobangų, radarų ir bevielių ryšių konferencija „MIKON-2010“. Vilnius, 2010 m. birželio $14-16 \mathrm{~d}$.

- Katkevičius, A. 2011. Dirbtinių neuronų tinklų taikymas lètinimo sistemų savybėms tirti. Keturioliktoji respublikinè Lietuvos jaunujų mokslininkų konferencija „Mokslas - Lietuvos ateitis“. Vilnius, $2011 \mathrm{~m}$. kovo $18 \mathrm{~d}$.

- Katkevičius, A., Štaras, S. 2011. Analysis of Rejection Properties of Meander Systems. Penkioliktoji tarptautine konferencija „Elektronika 2011 “. Vilnius, 2011 m. gegužès 17-19 d.

- Katkevičius, A. 2011. Calculation of Characteristics of Microwaves Devices Using Artificial Neuron Networks. Tarptautinis seminaras „Microwave and Light-Wave Systems“. Vilnius, $2011 \mathrm{~m}$. gruodžio $2 \mathrm{~d}$.

- Katkevičius, A. 2012. Lètinimo sistemų savybių tyrimas įvertinant nuostolius laidininkuose. Penkioliktoji respublikine Lietuvos jaunujų mokslininkų konferencija „Mokslas - Lietuvos ateitis“. Vilnius, $2012 \mathrm{~m}$. kovo $16 \mathrm{~d}$.

- Katkevičius, A., Martavičius, R. 2012. Automated synthesis method for inhomogeneous delay systems using artificial neural networks. XXII In- 
ternational Conference on Electromagnetic Disturbances „EMD2012“. Vilnius, $2012 \mathrm{~m}$. rugsèjo 20-21 d.

- Katkevičius, A. 2012. Delay systems modeling using artificial neural networks. Tarptautinis seminaras ,Modern Microwave Devices and Systems“. Minskas, Baltarusija, $2012 \mathrm{~m}$. lapkričio $18 \mathrm{~d}$.

\section{Disertacijos struktūra}

Disertaciją sudaro įvadas, keturi skyriai, kitų autorių ir autoriaus literatūros sąrašai, rezultatų apibendrinimas, bendrosios išvados ir 2 priedai.

Darbo apimtis yra 116 puslapiu, neskaitant priedu, tekste panaudotos 73 numeruotos formulès, 60 paveikslų ir 3 lentelès. Rašant darbą buvo panaudoti 128 literatūros šaltiniai. 


\section{1}

\section{Nevienalyčių lètinimo sistemų ir jų analizès metodų apžvalga}

Skyriuje analizuojamos lètinimo sistemų (LS) konstrukcijos, lètinimo sistemų taikymo sritys, analizès metodai bei analizei taikytina specializuota programinè įranga. Aptariama lètinimo sistemų tyrimo problema bei suformuluojami disertacijos darbo tikslas ir uždaviniai.

\subsection{Nevienalyčių lėtinimo sistemų modeliai ir tyrimas}

Elektroniniuose itaisuose ir sistemose plačiai taikomi tiesiniai paskirstytuju parametrų įrenginiai, kuriuose elektromagnetinès bangos fazès sklidimo greitis $v_{\mathrm{f}}$ yra plačiame dažnių ruože daug mažesnis už šviesos greitį vakuume $c_{0}$. Šie įrenginiai vadinami plačiajuostemis elektrodinaminèmis lètinimo sistemomis (Штарас et al. 1993).

Lètinimo sistemu paskirtis sulètinti sistema sklindantį signalą - sumažinti jo sklidimo greiti. Plačiajuostès vienalytès lètinimo sistemos, kaip ilgosios linijos, gali būti apibūdinamos dažninèmis ir laiko charakteristikomis. Svarbiausios LS savybes apibūdinančios dažninès charakteristikos - lètinimo koeficiento ir banginès varžos arba įèjimo varžos priklausomybès nuo dažnio. 
Lètinimo koeficientas rodo, kiek kartų elektromagnetinès bangos fazès sklidimo greitis mažesnis už šviesos greitị vakuume. Jis išreiškiamas formule:

$$
k_{\mathrm{L}}=\frac{\mathrm{c}_{0}}{v_{\mathrm{f}}}=\mathrm{c}_{0} \sqrt{L_{1} C_{1}}
$$

čia $L_{1}$ ir $C_{1}$ - sistemos ilginis induktyvumas ir ilginè talpa, $v_{\mathrm{f}}$ - fazinis greitis.

Banginè varža išreiškiama formule:

$$
Z_{\mathrm{B}}=\sqrt{\frac{L_{1}}{C_{1}}} .
$$

Daugeliu atvejų nevienalytès lètinimo sistemos priklausančią nuo koordinatès iejjimo varžą galima apskaičiuoti taikant formulę:

$$
Z_{\mathrm{IN}}=\frac{U(x)}{\underline{I}(x)},
$$

čia $\underline{U}(x)$ ir $\underline{I}(x)$ yra įtampos ir srovès kompleksinès amplitudès sistemos pjūvyje, kurio koordinate $x$.

Sprendžiant lètinimo įtaisų taikymo klausimus, greta aptartų charakteristikų naudojamos ir kitos charakteristikos, kurios priklauso nuo įtaisu paskirties. Vèlinimo linijų atveju svarbiausios charakteristikos - tai vèlinimo trukmés dažniné charakteristika, dažninè amplitudès charakteristika, dažninė fazès charakteristika ir pereinamoji arba impulsinè charakteristikos. Pereinamoji arba impulsinè charakteristikos vaizdžiai parodo perduodamų per LS impulsų formos iškraipymus, tačiau nepaaiškina jų priežasties. Iškraipymų priežasties nustatymui naudojamos dažninès LS charakteristikos.

Jei žinomas lètinimo koeficientas, vèlinimo trukmę $t_{\mathrm{v}}$ galima apskaičiuoti taikant formulę:

$$
t_{\mathrm{v}}=\frac{L_{\mathrm{S}}}{\mathrm{c}_{0}} k_{\mathrm{L}}
$$

čia $L_{\mathrm{S}}-$ lètinimo sistemos ilgis.

Pagal savo paskirtị ir struktūrą šiuo metu išskiriama spiralinès, meandrinès ir mikrojuostelinès lètinimo sistemos (Štaras et al. 2010). Spiralinèmis lètinimo sistemomis vadinami elektromagnetinių bangų perdavimui skirti ịtaisai, kuriuose yra bent vienas spiralinis laidininkas. Meandrinèmis lètinimo sistemomis vadiname tokią elektromagnetinių bangų perdavimo sistemą, kurioje bent vienas laidininkas turi meandro (zigzago) formą. Skirtingai nuo spiralinio laidininko meandrinis laidininkas paprastai būna plokščias. Meandrinèse lètinimo sistemo- 
se gali būti vienas arba du ištisiniai ekranai. Erdvę tarp meandrinio laidininko ir ekranų užpildo vienalytis arba sluoksniuotas magnetodielektrikas. Kai meandrinis laidininkas suformuojamas ant vienos dielektriko pagrindo pusès standartine plèvelinių integrinių schemų gamybos technologija, o kita pagrindo pusè ištisai metalizuojama, lètinimo sistema vadinama mikrojuosteline meandrine (Martavičius 1996).

Pirmosios spiralinès ir meandrinès LS buvo pradètos aptarinèti spaudoje XX a. penktajame ir šeštajame dešimtmečiuose (Kallmann 1946; Pierce 1950; Sensiper 1951). Tai buvo paprasčiausios stačiakampio skerspjūvio spiralinès ir zigzagu forma sulankstytos meandrinès linijos. Vèliau pradètos tyrinèti sudètingesnių konstrukcijų lètinimo sistemos (Тараненко, Трохименко 1965). LS pradètos taikyti bėgančiosios bangos vamzdžių ir kreipimo sistemose (Niklas, Wimpffel 1985).

Didejjant LS poreikiui buvo kuriami įvairūs lètinimo sistemų tyrimo metodai. Visų pirma lètinimo sistemoms buvo taikyti elektrodinaminis, ekvivalentinių schemų bei daugialaidžių linijų analitiniai metodai (Kirvaitis 1994). Šie metodai yra sudetingi - kiekvieną kartą pakeitus sistemos konstrukciją ir norint apskaičiuoti lètinimo koeficiento, iejjimo varžos ir kitas LS dažnines charakteristikas, reikia sudarinèti sudètingą sistemą apibrezžiantị matematinị modelị ir išvedinèti sistemos dispersinę lygti.

XX a. devintajame dešimtmetyje ženkliai padidèjus skaičiavimo technikos resursams, sudètingos konstrukcijos elektrodinaminių sistemų analizei vis dažniau pradèta taikyti skaitiniai metodai (Urbanavičius et al. 2009). Literatūros šaltinių analitinė apžvalga rodo, kad ịvairiems elektromagnetizmo uždaviniams spręsti dažniausiai taikomi skaitiniai baigtinių elementų, baigtinių skirtumų ir integralinių lygčių metodai (Sadiku 2009).

Nagrinèjant sudètingų lètinimo sistemų dažnines amplitudès ir fazès charakteristikas tikslinga linijas skaidyti ị daug smulkesnes sistemas ir taikyti matricinius metodus. Vienas iš galimų variantu yra $\boldsymbol{A B C D}$ matricų metodas (Zhou et al. 2008). Galimi ir kiti matriciniai metodai: $\boldsymbol{Z}$ - normuotų varžų; $\boldsymbol{Y}$ - normuotų laidžių; $\boldsymbol{B}-\beta$ parametrų; $\boldsymbol{H}-h$ parametrų, sklaidos matricos (Soluch 2012; Ye et al. 2010).

Lietuvoje elektrodinaminès lètinimo sistemos pradètos tyrinèti XX a. septintojo dešimtmečio viduryje tuometiniame Kauno politechnikos instituto Vilniaus filiale, kuris vèliau tapo Vilniaus Gedimino Technikos Universitetu. Prof. Z. Vainorio vadovaujama mokslininkų grupé sukūrè vieningą lètinimo-kreipimo sistemu analizès teoriją, ištyrè ir palygino daugelio šių sistemų charakteristikas ir savybes (Вайнорис et al. 1986). Prie elektrodinaminių lètinimo sistemų tyrimo ir jų taikymo elektroniniuose įtaisuose problemos sprendimo daug prisidejo prof., S. Štaras, R. Martavičius, R. Kirvaitis, J. Skudutis, V. Urbanavičius, docentai A. Gurskas, A. Jurjevas, V. Daškevičius, R. Pamarnacki ir kiti. Taikant 
elektrodinaminị ir daugialaidžių linijų metodus buvo tirtos spiralinès ir meandrinès lètinimo sistemos, kurių poreikis sparčiai augo. Lètinimo sistemų teoriniai ir eksperimentiniai tyrimai, jų gamybos ir taikymo problemos apibendrintos monografijose (Štaras et al. 2012), planarinių lètinimo sistemų modeliavimo teorija, meandrinių lètinimo sistemų savybès (Martavičius 1994), o meandrinių vèlinimo linijų analizè ir projektavimas disertacijoje (Urbanavičius 1995).

Nežiūrint to, kad plačiajuostès elektrodinaminès lètinimo sistemos tirtos daugelyje darbų, dar yra daug neišspręstų klausimų: sudètingo skerspjūvio nesimetrinių ir simetrinių spiralinių ir meandrinių sistemų savybių tyrimas, periodinių netolygumu ịtakos sistemų savybėms tyrimas, daugkartinių atspindžių įtakos tyrimas, lètinimo sistemų modeliavimo algoritmų tobulinimas.

\subsection{Nevienalyčių lėtinimo sistemų taikymo sritys}

Spiralinės ir meandrinès konstrukcijos LS plačiai naudojamos signalų vèlinimo sistemose, nanosekundinių ir subnanosekundinių video impulsų ir kitų plataus spektro signalu stebejimui ir registravimui skirtuose itaisuose (Cormack et al. 1993; Zhu et al. 2007), superaukšto dažnio virpesių generatoriuose, stiprintuvuose (Booske et al. 2011; Srivastava et al. 2008). Taip pat jos naudojamos antenose (Nassar, Weller 2011; Gong et al. 2011; Liu et al. 2012), filtruose (Hsu, Tu 2012; Wang et al. 2010; Cui et al. 2011), šakotuvuose (Chiang et al. 2010; Ymeci et al. 2011; Imeci et al. 2011), monolitiniuose integriniuose grandynuose (Chang W. S, Chang C. Y. 2012; Maloratsky 2009; Maloratsky 2011) ir pan.

Siame poskyryje aptariamos LS taikymo sritys ir LS taikymo pavyzdžiai.

\subsubsection{Spiralinès konstrukcijos lètinimo sistemų taikymo sritys}

Spiralinès lètinimo sistemos (SLS) šiuo metu plačiai taikomos bėgančiosios bangos elektroninių vamzdžių sistemose (BBEVS), kurios plačiai taikomos komercineje ir karineje elektronikoje mikrobangu stiprinimui ir generavimui. BBEVS buvo kuriamos ryšių sistemoms, bet rado savo pritaikymą radarų sistemose, matavimų prietaisuose, elektroninių ginklų gamyboje.

Daugelị metų vakuuminès BBEVS buvo vienintelis didelès galios mikrobangų stiprintuvų ir generatorių šaltinis. Pasirodžius didelès galios kietojo kūno itaisams, tokiems kaip $L D M O S$ lauko tranzistoriu integriniai grandynai (IG), dirbantiems iki 1,5 GHz dažniuose, GaN PHEMT IG, dirbantiems 1-18 GHz dažnių ruože, ir GaAs ar InP IG, kurių darbo dažnių ruožas siekia $94 \mathrm{GHz}$, atsirado galimybè gaminti naujos sandaros kietojo kūno galios stiprintuvus (KKGS).

KKGS tam tikrais konkrečiais mikrobangu perdavimo įtaisų atvejais siūlo pigesnį alternatyvų variantą, lyginant su BBEVS, tačiau kietojo kūno galios stip- 
rintuvų galia yra mažesnè ir jie veikia siauresniame dažnių ruože. Griežtejjant reikalavimams - didesnis efektyvumas, mažesnè šiluminè sklaida, didesnis patikimumas, ilgas tarnavimo laikas, didelis radiacinis atsparumas - BBEVS išlaikè savo rinkos pozicijas.

Visame pasaulyje BBEVS gamina nedaug gamintojų. Pagrindiniai iš jų yra $C P I, L-3$ ir Teledyne iš JAV, e2v, Thales ir TMD iš Europos, NEC iš Japonijos ir keli gamintojai Kinijoje ir Indijoje (Coaker, Challis 2008).

Remiantis gamintojų ir mokslinių šaltinių rekomendacijomis galima teigti, kad priklausomai nuo sprendžiamo uždavinio privalumų ir trūkumų turi tiek BBEVS, tiek ir KKGS. Yra daug veiksnių, lemiančių tinkamą sistemos pasirinkimą. 1.1 lentelèje pateikta BBEVS ir KKGS pasirinkimo konkrečiai užduočiai kriterijų palyginimo matrica, sudaryta Teledyne įmonés mokslininkų.

1.1 lentelè. BBEVS ir KKGS kriterijų palyginimo matrica (Teledyne 2009)

Table 1.1. Criteria comparison matrix of TWTAs and SSPAs systems (Teledyne 2009)

\begin{tabular}{|c|c|c|c|}
\hline Režimas & Parametras & BBEVS & KKGS \\
\hline \multirow{4}{*}{$\begin{array}{l}\text { Didele galia } \\
>500 \mathrm{~W} \text { ir } 1 \mathrm{GHz}(\mathrm{NS}) \\
>50 \mathrm{~W} \text { ir } 30 \mathrm{GHz} \text { (NS) } \\
>1 \mathrm{KW} \text { ir } 1 \mathrm{GHz} \text { (IS) } \\
>100 \mathrm{~W} \text { ir } 30 \mathrm{GHz} \text { (IS) }\end{array}$} & $\begin{array}{l}\text { Siaura juosta } \\
<20 \% \text { juostos pločio }\end{array}$ & Geras & Priimtinas \\
\hline & $\begin{array}{l}\text { Plati juosta } \\
>50 \% \text { juostos pločio }\end{array}$ & Geras & Blogas \\
\hline & Dydis & Geras & Priimtinas \\
\hline & Efektyvumas & Geras & Blogas \\
\hline \multirow{4}{*}{$\begin{array}{l}\text { Maža galia } \\
<50 \mathrm{~W} \text { ir } 1 \mathrm{GHz}(\mathrm{NS}) \\
<5 \mathrm{~W} \text { ir } 30 \mathrm{GHz}(\mathrm{NS}) \\
<100 \mathrm{~W} \text { ir } 1 \mathrm{GHz}(\mathrm{IS}) \\
<10 \mathrm{~W} \text { ir } 30 \mathrm{GHz} \text { (IS) }\end{array}$} & $\begin{array}{l}\text { Siaura juosta } \\
<20 \% \text { juostos pločio }\end{array}$ & Blogas & Geresnis \\
\hline & $\begin{array}{l}\text { Plati juosta } \\
>50 \% \text { juostos pločio }\end{array}$ & Priimtinas & Geresnis \\
\hline & Dydis & Priimtinas & Geresnis \\
\hline & Efektyvumas & Priimtinas & Geresnis \\
\hline $\begin{array}{l}\text { Darbo temperatūra } \\
>75^{\circ} \mathrm{C} \text { aplinkoje }\end{array}$ & & Geras & Priimtinas \\
\hline
\end{tabular}

NS - nuolatinio stiprinimo, IS - impulsinio stiprinimo.

Remiantis 1.1 lentele matyti, kad BBEVS sistemų galios ir dažnio parametrai yra glaudžiai susiję. Remiantis galios ir dažnio vertemis Teledyne mokslininkai nubrěžè ribas, kada geriau taikyti BBEVS. Pavyzdžiui radarų sistemose taikoma BBEVS dažnių sritis nuo 1 iki $18 \mathrm{GHz}$, kai maksimalios galios verte siekia $12 \mathrm{~kW}$, o vidutinè galia daugiau nei $700 \mathrm{~W}$. Stiprintuvuose taikomi impul- 
siniai bėgančiosios bangos elektroniniai vamzdžiai 1-44 GHz dažniuose, kai vidutinè sistemos galia siekia $750 \mathrm{~W}$.

Spiraliniai bėgančios bangos vamzdžiai taikomi karo pramonèje (Xavier, Motta 2009). Vienas iš BBEVS pritaikymo pavyzdžių yra elektromagnetinè patranka (Sharma et al. 2009). Karo pramonei gaminamos BBEVS, naudojamos didelès iki $500 \mathrm{~W}$ siekiančiuose stiprintuvuose, dirbančiuose $26,5-40 \mathrm{GHz}$ dažnių srityje (NEC 2013, L-3 2013).

Aviacijos elektronikoje reikalingi mažų matmenų ir svorio mikrobangų stiprintuvai. Pastaraisiais dešimtmečiais aviacijos sistemoms sukurtos BBEVS dirba 4,5-18 GHz dažnių ruože esant $100 \mathrm{~W}$ ir didesnei galiai pastoviosios fazès ir amplitudès režime. BBEVS išbandytos $(-55-150){ }^{\circ} \mathrm{C}$ temperatūrų ruože iki 20 tūkstančių metrų aukštyje, veikiant $500 \mathrm{G}$ jègai i masès vienetą. Mini BBEVS minimalūs matmenys siekia 15,24 ×2,54 ×2,54 mm (e2v 2013). Tokios sistemos tinka fazinių gardelių ir sintezuotosios apertūros radarams (CPI 2013).

Kosmose taikomų BBEVS tarnavimo trukmè išaugo iki šešių milijonų valandų su 50 procentų efektyvumu. Kosmose taikomų BBEVS pagrindiniai privalumai yra ilgaamžiškumas (tarnavimo trukmé didesnè nei 20 metų), didelis patikimumas, mažas energijos suvartojimas, didelis efektyvumas ir atsparumas perkrovoms (Thales 2013).

BBEVS ypač plačiai taikomos THz dažnių diapazono virpesių stiprintuvuose ir generatoriuose (Duan et al. 2008; Kory et al. 2009; Krozer, Zhurbenko 2010; TMD 2013).

Nors BBEVS plačiai taikomos, yra dar daug neišspręstų ir tobulintinų klausimų. Tai parodo gausa straipsnių, susijusių su BBEVS tobulinimu (e2v 2008). Darbe (Marchewka et al. 2010) aptariama mini BBEVS, kurios galia siekia daugiau nei $125 \mathrm{~W}$, dirbant 26-32 GHz darbo dažnių diapazone. Daugelyje darbų nuodugniai tyrinejjama išorinių veiksnių itaka BBEVS darbo kokybei (Boyle et al. 2012). Plačiai tyrinèjama BBEVS spiralinio laidininko struktūra ir dèl jos susidarančiu periodinių netolygumų įtaka dažninėms charakteristikoms (Alaria et al. 2010; Štaras, Burokas 2006).

Aptarti spiralinių lètinimo sistemų paskirti BBEVS lengviausia nagrinejjant BBEVS veikimą, kai nuolatinès srovès maitinimo šaltinio energija yra transformuojama i aukštojo dažnio virpesių energiją. Mikrobangų ruožo bėgančiosios bangos itaisuose tai pasiekiama stiprinamai bangai sąveikaujant su judančių elektronu pluošteliu (1.1 pav.). Ši sąveika rezultatyvi, jeigu elektromagnetinès bangos fazinis greitis artimas elektronu greičiui, bet šiek tiek už ji mažesnis. Todèl bègančiosios bangos įtaisuose esminis ir būtinas elementas yra lètinimo sistema (Vainoris 2004).

BBEVS dažniausiai taikomas spiralinis lètinimo sistemos laidininkas, pasižymintis geromis dispersinèmis savybèmis ir plačia darbo dažnių juosta. SLS darbinès charakteristikos gali būti valdomos keičiant laidininko formą, siekiant 
pagerinti tiek siaurajuosčio, tiek ir plačiajuosčio ryšio veikimą, optimizuojant srovę, galią ir efektyvumą. Dispersinès charakteristikos gali būti kontroliuojamos priklausomai nuo spiralinio laidininko formos (Štaras et al. 2006), ekranu (Štaras 2005; Daškevičius et al. 2008.), laikiklių (Burokas 2004) ir jiems taikomų medžiagų.

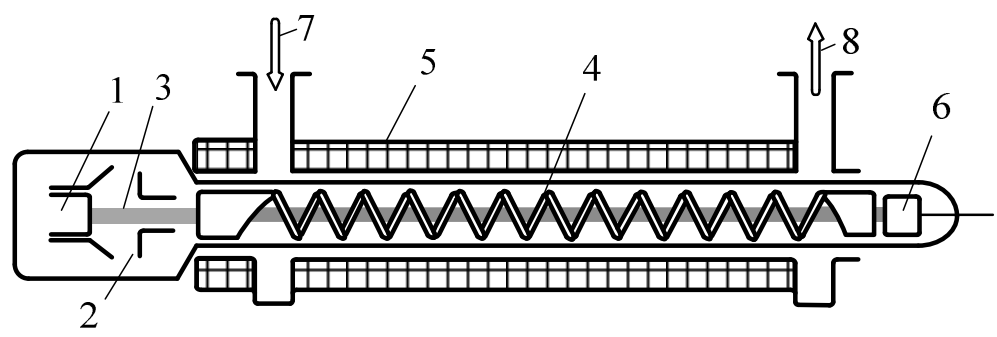

1.1 pav. Mikrobanginių virpesių bėgančiosios bangos stiprintuvas (Vainoris 2004):

1 - elektronų patranka; 2 - greitinantis elektrodas; 3 - elektronų pluoštelis;

4 - spiralinè lètinimo sistema; 5 - elektronų fokusavimo selenoidas; 6 - kolektorius;

7 ir 8 - ièjimo ir išèjimo bangolaidžiai

Fig. 1.1. Microwave traveling wave tube (Vainoris 2004): 1 - electron gun;

2 - accelerating electrode; 3 - electron beam; 4 - helical delay system; 5 - electron focusing selenoid; 6 - collector; 7 and $8-\mathrm{RF}$ input and output

Spiralinès konstrukcijos lètinimo sistemos taip pat taikomos antenų ir filtrų gamyboje. Spiralinès konstrukcijos laidininko filtrai naudojami ultra aukštujų dažnių mobiliuosiuose įrenginiuose, kur ịprasti sutelktujjų elementų filtrai yra per daug nuostolingi (Yu, Dokas 2004). Darbe (Radway, Filipovic 2012) pristatoma $0,35-2,6 \mathrm{GHz}$ dažnių ruože veikianti spiralinè antena.

\subsubsection{Meandrinès konstrukcijos lètinimo sistemų taikymo sritys}

Šiuo metu meandrinès lètinimo sistemos yra plačiausiai taikomos projektuojant antenas. Antenos dydis efektyviai sumažinamas antenos dipoliui panaudojant meandro formos laidininką, todèl tokios antenos yra paplitusios mobiliuosiuose įrenginiuose. Taip nepakeičiant antenos dažninių charakteristikų efektyviai sumažinamas antenos dydis. Antenos dydis sumažeja proporcingai meandro vijų skaičiui (Singh et al. 2008). Darbe (Pham et al. 2004) aprašoma antena, veikianti dviejuose 900/1800 MHz dažnio ruožuose, skirta mobiliojo ryšio sistemoms. Jos meandras (1.2 pav.) skirtas pasiekti $900 \mathrm{MHz}$ rezonansini dažnį. Projektuojant meandrą tarp gretimų laidininkų naudojami skirtingi atstumai. Antenos matmenys yra $14 \times 17 \mathrm{~mm}$. 


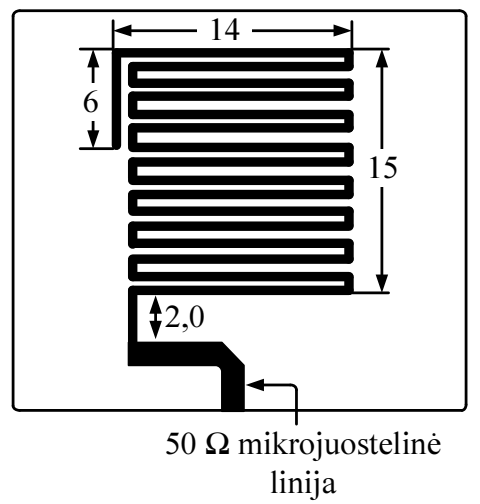

1.2 pav. Žemojo profilio antenos, veikiančios dviejuose ruožuose, eskizas ir matmenys (Pham et al. 2004)

Fig. 1.2. The geometry and dimensions of low profile meander line antenna for dual-band operation (Pham et al. 2004)

Šiuo metu antenų gamyboje tyrinejjamos ivvairios meandrinio laidininko konstrukcijos. (Aziz et al. 2012) tyrinejjama bevielio lokalaus tinklo antena, dirbanti $2,4 \mathrm{GHz}$ dažnyje, sudarytą iš dviejų meandro laidininkų. Lyginant su antena, turinčia paprastą vieno meandro laidininką, dviejų meandro laidininkų konstrukcijos grịžtamieji nuostoliai yra didesni ir lygūs $-24,54 \mathrm{~dB}$, bet pasiekta siauresnè pageidaujama darbo dažnių juosta nuo $2,417 \mathrm{GHz}$ iki 2,472 GHz.

Identifikavimo radijo bangomis RFID sistemose taikomos ultra aukštujų dažnių meandrinės antenos. Vienas iš ultra aukštujų dažnių antenų reikalavimų yra nedideli gabaritai, kurie pasiekiami naudojant meandro formos dipolị. Meandrinis dipolis taipogi leidžia teisingai nustatyti antenos darbo dažnių sritị ir antenos kryptingumą. Sumažinus antenos dydị sunku anteną suderinti su didelę talpą turinčiu integriniu grandynu. Esant sumažintam antenos dydžiui triju papildomų apkrovos juostelių naudojimas, kurios induktyviai surištos su meandro formos antenos dipoliu, leidžia tiksliau kontroliuoti iejjimo varžos vertes. Tokiu būdu antena tiksliau suderinama su didelę talpą turinčiu likusiu ultra aukštų dažnių IG (Toccafondi, Braconi 2006).

Fazuotos anteninès gardelès ir iš jų sudarytos radarų sistemos pasižymi mažais matmenimis. Be to, jų kryptingumo diagrama reguliuojama elektroniniu būdu, todèl išvengiant didelio mechaninio inertiškumo tokio tipo antenos ar radarai gali greitai pakeisti savo kryptingumo diagramą ir pereiti prie kito erdvès taško stebejjimo. Yra išskiriami du būdai tokio tipo antenų kryptingumo diagramai valdyti. Pirmuoju atveju taikomi fazès keitikliai, koreguojantys kiekvieno antenos elemento fazę. Šis būdas jautrus dažnio pokyčiui. Antruoju būdu antenos kryptingumo diagrama valdoma realiame laike užvèlinant atskirų antenos 
elementų signalus. Signalų vèlinimui taikomos ịvairaus tipo lètinimo sistemos, tarp jų ir meandrinès konstrukcijos vèlinimo linijos (Longbrake 2012).

Mažinant antenų matmenis mažejja ir meandrinès konstrukcijos lètinimo sistemos, dèl ko mažèja atstumas tarp gretimų meandro laidininkų ir didejja gretimų meandro laidininku įtaka vienas kitam, nes gretimuose meandro laidininkuose srovè teka priešingomis kryptimis. Siekiant išvengti gretimų meandro laidininkų įtakos vienas kitam, siūlomas hibridinès spiralè-meandras konstrukcijos lètinimo sistemos modelis (Yoon et al. 2005). Meandrinè struktūra yra klojama iš abiejų pagrindo plokštelès pusių taip sudarydama spiralinę struktūrą. Dèl tokios struktūros srovè gretimuose laidininkuose vienoje pagrindo pusèje visados tekès ta pačia kryptimi ir bus išvengta gretimų laidininkų itakos (1.3 pav.).

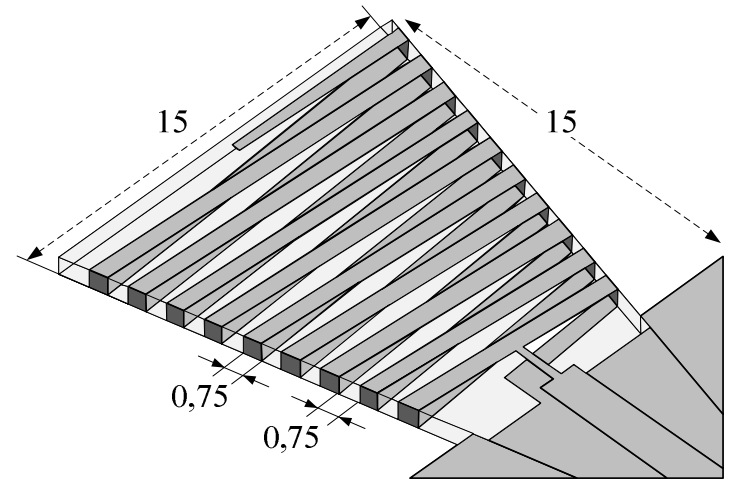

1.3 pav. Spirale suvyniotos meandrinès antenos eskizas (Yoon et al. 2005)

Fig. 1.3. The sketch of the geometry of spirally wrapped meander antenna (Yoon et al. 2005)

Kitą grupę itaisų, kuriuose plačiai taikomos meandrinès lètinimo sistemos, sudaro filtrai. Siekiant sumažinti dviejų modų juostinio filtro matmenis, (Gorur, Karpuz 2007) darbe siūloma naudoti meandro formos rezonatorių. Toks filtras naudojamas palydoviniame ir mobiliajame ryšiuose. Dar efektyviau filtro matmenys sumažinti, naudojant ketvirtosios eilès meandrinès struktūros juostinį filtrą. Vieta sutaupyta panaudojus meandrinị kilpos formos rezonatorių (1.4 pav.). Eksperimentiniai rezultatai patvirtino, kad sukurtas dviejuose dažnių režimuose dirbantis juostinis filtras turi platesnę užtvarinę juostą ir geresnį selektyvumą (Sun et al. 2012).

Meandro formos laidininkai taip pat naudojami projektuojant užtvarinius filtrus su plačia užtvarine juosta. (Wang et al. 2010) darbe aptariamas filtras, kuris pasižymi didesniu nei $15 \mathrm{~dB}$ slopinimu dažnių ruože nuo $1,8 \mathrm{iki} 8,8 \mathrm{GHz}$, o jo matmenys yra $13,2 \times 13,2 \mathrm{~mm}$. Šiuo atveju meandras naudojamas perdavimo linijos ilgiui padidinti. 


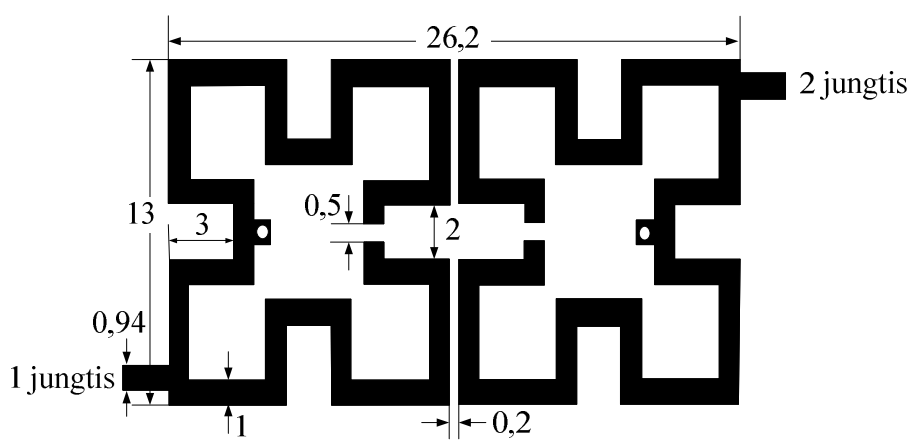

1.4 pav. 4-osios eilès juostinio filtro struktūra ir matmenys (Sun et al. 2012)

Fig. 1.4. Layout with dimensions of the 4 th-order band pass filter (Sun et al. 2012)

Panašus filtras projektuojamas (Ge et al. 2010) darbe. Šis filtras turi itin plačią užtvaros juostą ir pasižymi didesniu nei $17 \mathrm{~dB}$ slopinimu dažnių juostoje nuo 2 iki 14,6 GHz. Filtro matmenys $-11 \times 19 \mathrm{~mm}$.

Meandro formos linijos taip pat naudojamos projektuojant šakotuvus (Wei et al. 2012) ir fazès keitiklius (Bulja, Mirshekar-Syahkal 2010). Šakotuvą, pavaizduotą 1.5 paveiksle sudaro dvi meandrinès linijos, išdèstytos skirtinguose sluoksniuose. Tokie įtaisai gali būti taikomi monolitiniuose mikrobangų integriniuose grandynuose.

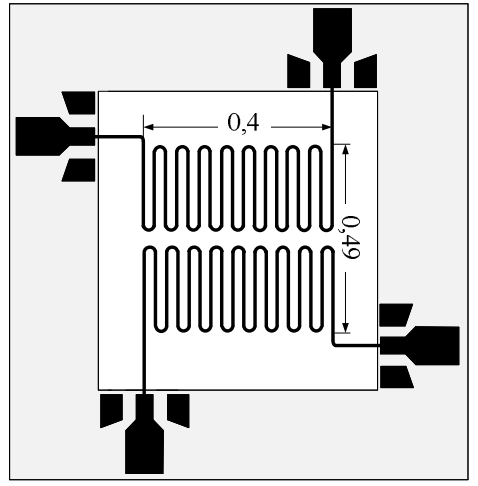

1.5 pav. Kelių sluoksnių meandrų hibridinis šakotuvas (Jung Gil Yang et al. 2006) Fig. 1.5. Hybrid coupler using multi-layer microstrip lines (Jung Gil Yang et al. 2006)

Kita planarinių meandrinių lètinimo sistemų taikymo sritis yra monolitiniai integriniai grandynai (Maloratsky 2011). Integriniuose grandynuose iškylanti problema iliustruojama 1.6 paveiksle. Problema atsiranda, norint persiųsti signalus 1,2 ir 3 takeliais iš vieno mikro grandyno ị kitą su tiksliai tokiu pačiu uždel- 
simu. Esant skirtingiems takelių ilgiams trečiuoju takeliu sklindantis signalas turi nueiti ilgesni kelią ir bus uždelstas daugiau (1.6. pav. a). Ši problema išsprendžiama taikant meandrines lètinimo sistemas (1.6. pav. b), išvengiant integrinio grandyno matmenų padidejimo (Powers, Cruz 2000).

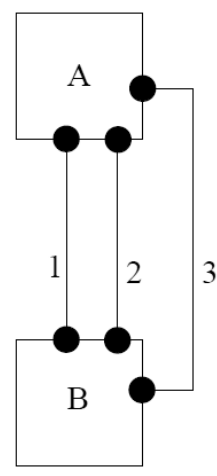

(a)

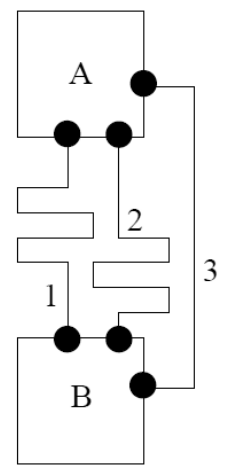

(b)

1.6 pav. Skirtingo takelių ilgio (a) ir vienodo takelių ilgio (b) integrinių grandynu takelių konfigūracijos (Powers et al. 2000)

Fig. 1.6. Unequal wire lengths (a) and equal wire lengths of wire configuration of integrated circuits (Powers et al. 2000)

Meandrinių lètinimo sistemų taikymo integriniuose grandynuose pavyzdžiai: takeliai tarp procesoriaus ir atmintinès, takelių medis tarp taktinio dažnio generatoriaus ir jo valdomų grandinių.

Praeityje meandrinès lètinimo sistemos buvo naudojamas su prielaida, kad papildomas laido ilgis nekeičia linijos savybių ir neatsiranda parazitinių reiškinių. Mažejant integrinių grandynų matmenims, kartu mažèjant atstumams tarp gretimų meandro takelių bei augant darbiniams dažniams ị parazitinius reiškinius būtina atsižvelgti. Darbe (Kabiri et al. 2010) lyginami meandrinès struktūros laidininko ir tokio paties ilgio tiesaus laidininko vèlinimo laiko ir banginès varžos matavimų rezultatai.

Taikant meandrines lètinimo struktūras integrinių grandynų technologijoms ypač svarbu teisingai suderinti pagrindo plokštelès storio $h$ mažinimą su laidininko pločio $w$ mažinimu, siekiant išlaikyti pastovią banginę varžą $Z_{\mathrm{B}}(1.7$ pav.). Meandrinès lètinimo sistemos banginè varža visų pirma nustatoma remiantis laidininko pločio $w$ ir pagrindo padèklo storio $h$ santykiu. Mažinant abu šiuos dydžius įmanoma minimizuoti integrinio grandyno matmenis, bet tuomet sudètingèja gamybos procesas ir didèja sistemos varžiniai nuostoliai (Darwish, Ezzeddine 2009). 


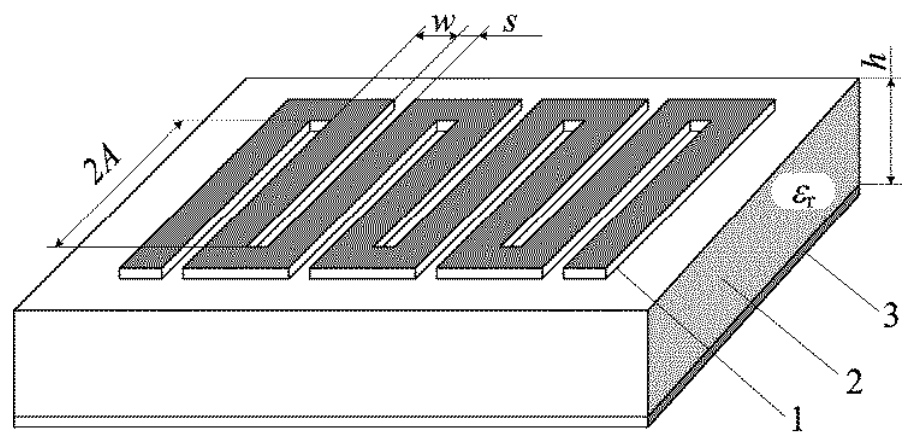

1.7 pav. Meandrinès lètinimo sistemos vaizdas (Urbanavičius et al. 2000):

1 -meandro formos laidininkas; 2 - dielektriko pagrindas; 3 - ištisinis ekranas

Fig. 1.7. The design of the microstrip slow-wave system (Urbanavičius et al. 2009):

1 - meander shape conductor; 2 - dielectric substrate; 3 - solid shield

Gretimų meandrinès lètinimo sistemos laidininkų priešingų krypčių srovès sumažina bendrą sistemos induktyvumą. Teigiama, kad abipusio ryšio efektas yra mažas, kai atstumas tarp gretimų meandrinès lètinimo sistemos laidininkų yra bent tris kartus didesnis nei laidininko plotis (Kirvaitis 1994). Siekiant optimalaus suderinimo tarp šaltinio ir apkrovos meandro laidininkas turi būti specifinès formos (Metlevskis, Urbanavičius 2011). Darbe (Fakharzadeh et al. 2008) siūloma meandrinè konstrukcija su nugludintais kampais, tokiu atveju pasiekiant $8 \mathrm{~dB}$ mažesnius atspindžius.

Darbe (Gurskas et al. 2010) teigiama, kad tobulinant meandrinio laidininko kraštines sritis galima žymiai padidinti vélinimo trukmę ir padidinti skaičiavimų tikslumą. Darbe (Metlevskis, Martavičius 2012) nagrinèjama skirtingose sistemos vietose ižzemintų papildomų ekranų ịtaka meandrinių lètinimo sistemų dažninèms vèlinimo trukmès ir iejjimo varžos charakteristikoms.

Dabartinis bevielio ryšio technologijų vystymasis skatina perspektyvų metodą kurti daugiasluoksnius mikrobangu grandynus, laminuojant kelis mikrobangu grandinių sluoksnius vieną ant kito. Šis metodas ženkliai sumažina įrenginio matmenis. Toks lusto miniatiūrizavimas didina varžinius nuostolius. Siekiant išvengti varžinių nuostolių, siūloma naudoti $50 \Omega 1 \mathrm{~mm}$ ilgio meandrinę lètinimo sistemą (Darwish et al. 2009).

Apibendrinant galima teigti, kad yra daug spiralinių ir meandrinių lètinimo sistemu taikymo sričių. Kuriant naujas sistemas neišvengiamai spiralines ir meandrines lètinimo sistemas tenka tobulinti, nes esami lètinimo sistemų modeliai nebeužtikrina aukštų keliamų reikalavimų. Spiralinių ir meandrinių lètinimo sistemu taikymo problemos ir jų analizès metodai aptariami sekančiuose skyreliuose. 


\subsection{Nevienalyčių lètinimo sistemų tyrimams taikomi metodai}

Pasaulio mokslininkai daug nuveikè kurdami ir taikydami mikrobangu įtaisams modeliuoti skirtus metodus (Gurskas 1995; Bhobe et al. 2001; Shugurov, Nickelson 2005; Clayton 2008). Kadangi net paprasčiausios elektrodinaminès sistemos atveju tikslus matematinis Maksvelo lygčių sprendimas neįmanomas, nes neįmanoma ịvertinti konkrečių kraštinių sąlygų ir atskirti Maksvelo lygčių kintamujų, todèl naudojami artutiniai metodai, geriau ar prasčiau įvertinantys realius fizikinius procesus nagrinejjamose sistemose.

Iš pradžių lètinimo sistemų tyrimams taikyti analitiniai tyrimo metodai. Analitiniai metodai smulkiau skirstyti ị elektrodinaminius, ekvivalentinių schemų bei daugialaidžių linijų. Analitiniai metodai remiasi apytikslemis skaičiavimo formulèmis. Šiu metodu privalumas yra didelè skaičiavimo sparta, o trūkumai - mažas skaičiavimo tikslumas ir nedidelis lankstumas.

Populiariausias buvo elektrodinaminis metodas, kuri taikant dažniausiai nagrinètos nesudètingo skerspjūvio spiralinès sistemos (Kirvaitis 1994). Skaičiuojant vèlinimo linijų parametrus elektrodinaminiu metodu sprendžiamos Maksvelo lygtys. Sprendžiant šias lygtis kartu su kraštinėmis sąlygomis laidžiuose paviršiuose galima nustatyti lètinimo sistemos elektromagnetinio lauko dedamuju pasiskirstymą jos skerspjūvio plokštumoje, linijos ilgio vieneto parametrus ir įejjimo varžos išraišką, linijos dispersinę lygti. Svarbus šio metodo privalumas yra galimybe gauti paprastas orientaciniams inžineriniams skaičiavimams tinkančias formules, kurias taikant galima apskaičiuoti lètinimo koeficientą ir banginę varžą.

Ekvivalentinių schemų analizès metodas pagrịstas nagrinèjamos lètinimo sistemos ekvivalentinès schemos iš pakopomis sujungtų keturpolių ir daugiapolių sudarymu. Kiekvienas daugiapolis sudarytas iš tarpusavyje sujungtų sutelktųjų talpu ir induktyvumų parametrų, o taip pat ilgujų linijų atkarpų (Gorbunova, Kuznetsov 2011). Sudarytoji ekvivalentine schema analizuojama taikant filtru arba ilguju linijų teoriją. Darbe (Štaras et al. 2010) teigiama, kad meandrinès vèlinimo linijos pateikimas ekvivalentine schema supaprastina analizę ir daro ją vaizdžią bei leidžia išsiaiškinti linijų savybes, sunkiai analizuojamas kitais metodais, tačiau taikant šị metodą neįmanoma nustatyti elektrinio lauko struktūros vèlinimo linijoje. Be to, jis galioja tik tam tikrame, ribotame dažnių ruože. Pasikeitus dažniui gali pakisti ir vèlinimo linijos elektrinio lauko struktūra. Tuomet tektų keisti ekvivalentinès schemos parametrus arba net iš esmès visą schemą. Sudètingiausia naudojant ekvivalentinių schemų metodą yra tiksliai nustatyti ryšį tarp nagrinejjamos lètinimo sistemos konstrukcijos bei matmenų ir ekvivalentinès schemos parametrų. Ekvivalentinès schemos elementų parametrai nustatomi taikant lauko teoriją arba eksperimentiškai. 
Daugialaidžiu linijų metodas plačiausiai taikomas modeliuojant vèlinimo ir kitas periodines sistemas (Zyuryukin 2006). Daugialaidè linija - tai sistema, sudaryta iš lygiagrečių vienas kitam laidininkų, kurių geometriniai matmenys ir konstrukcija turi sutapti su modeliuojamos vèlinimo linijos skerspjūvio matmenimis ir konstrukcija. Kiekvienas daugialaidès linijos laidininkas iš abiejų jo galų apkraunamas varžomis, užtikrinančiomis ịtampų ir srovių vienodumą modelyje ir modeliuojamoje vèlinimo linijoje. Varžų parinkimas vadinamas kraštinių sąlygų sudarymu. Taikant daugialaidžių linijų metodą lètinimo sistemų analizei reikia žinoti daugialaidžių linijų, kuriomis tos sistemos modeliuojamos, bangines varžas arba banginius laidžius. Banginių varžų ir banginių laidžių skaičiavimo metodai skirstomi i dvi grupes. Pirmają grupę sudaro analitiniai ekvivalentiniu talpų ir konforminių pakeitimų metodai. Antrają grupę sudaro baigtinių elementų, baigtinių skirtumų, momentų bei kiti metodai, pagrịsti skaitiniais Laplaso lygties sprendimo būdais. Jei didelis skaičiavimo tikslumas nebūtinas, banginès varžos skaičiuojamos konforminių pakeitimų ar dalinių talpų metodais. Kitais atvejais taikomas baigtinių skirtumų metodas.

Meandrinių sistemų analizei dažniau taikytas daugialaidžių linijų metodas (Burokas, Štaras 2008). Daugialaidžių linijų metodas taip pat plačiai taikytas ištęsto stačiakampio spiralinių lètinimo sistemų analizei (Štaras et al. 2012). Lètinimo sistemos modeliuotos daugialaide linija, kurios lygiagrečios laidininkų atkarpos yra statmenos modeliuojamos sistemos ašiai, o skerspjūvio matmenys ir konstrukcija sutampa su nagrinèta sistema. Daugialaidès linijos laidininku galai sujungiami taip, kad būtų modeliuojama meandrinè ar spiralinè lètinimo sistema. Daugialaidžių linijų metodas leidžia ịvertinti laidininko konfigūraciją ir matmenis. Skaičiuojant nagrinejjamos sistemos letinimo koeficientą ir banginę varžą, reikia rasti modeliuojančios daugialaidès linijos banginius laidžius ar bangines varžas. Jiems skaičiuoti buvo taikomi dalinių talpų ir konforminių pakeitimų banginių laidumų skaičiavimo metodai (Štaras et al. 2010).

Taikant skaitinių metodų grupę, lyginant su analitiniais metodais, galima gauti daug tikslesnius rezultatus, analizuoti ivairių matmenų ir nestandartinès geometrijos sistemas (Glover et al. 2005; Štaras 2008). Skaitiniai metodai pagrịsti skaitiniais Maksvelo, elektrostatikoje - Puasono ir Laplaso, lygčių sprendimo būdais. Maksvelo lygtys gali būti užrašytos diferencialine ir integraline formomis (Vainoris 2004), todèl yra išskiriamos dvi skaitinių metodų grupès.

Pirmosios grupès metodais sprendžiamos diferencialinès lygtys su dalinèmis išvestinèmis - taikomi baigtinių skirtumų (Garg 2008), baigtinių elementų, baigtinių skirtumų laiko srities metodai (Bhobe 2001). Antrosios grupès - integraliniu lygčių - metodai taikomi integralinèms lygtims spręsti. Vienas svarbiausių antrosios grupès metodų - momentų metodas (Mikučionis, Urbanavičius 2010). Skaitinių metodų trūkumas lyginant su analitiniais metodais - reikalauja didesnių kompiuterinių resursų ir skaičiavimai trunka ilgiau (Štaras 2008). 
Baigtinių skirtumų metodas pagrįstas Laplaso lygties užrašymu skirtumine forma ir jos sprendimu skaitiniu metodu (Sadiku 2009). Linijos skerspjūvis yra suskaidomas tinkleliu ir viso skerspjūvio begalinis taškų skaičius pakeičiamas tinklelio mazgų baigtiniu skaičiumi. Pasirinkus pradinius ir nekintančius linijos laidžiujų dalių potencialus ir atliekant iteracinį skaičiavimą randamas potencialo pasiskirstymas nagrinejjamame skerspjūvyje. Remiantis potencialo pasiskirstymu randami kiti sistemos parametrai. Skaičiavimo baigtinių skirtumų metodu tikslumas didejja didinant tinklelio mazgų skaičių, tačiau didejjant mazgų skaičiui gaunami didesni duomenų masyvai, reikia daugiau skaičiavimo įrangos atminties ir išauga skaičiavimo trukmè (Meerschaert et al. 2006; Krukonis 2009).

Taikant baigtinių elementų metodą skaičiuojamoji sritis suskaidoma ị elementus, kuriuose lauką apibūdinančio diferencialinio dydžio kitimo dèsnis keičiamas dažniausiai nesudètinga interpoliacine funkcija. Taikant baigtinių elementų metodą labai svarbi skaičiuojamosios srities suskaidymo i elementus procedūra. Lyginant baigtinių skirtumų ir baigtinių elementų metodus teigiama (Bhobe 2001; Štaras 2008), kad antrasis yra universalesnis, tačiau, priešingai negu baigtinių skirtumų metodas, reikalauja didesnių kompiuterinių resursų: reikia daugiau darbo paruošiant pradinius duomenis ir programas.

Aptartiems skaitiniams metodams būdinga tai, kad diferencialinės lygtys ir išvestinès pakeičiamos funkcijų skirtumais. Kitai elektromagnetinių uždavinių sprendimo metodų grupei būdinga tai, kad sprendžiamos integralinès lygtys ir skaitinis integravimas igyvendinamas taikant sumavimą. Šie metodai vadinami integralinių lygčių metodais. Prie šių metodų priskiriamas momentų metodas (Metlevskis, Urbanavičius 2010). Norint rasti linijos ilginę talpą ir banginę varžą momentų metodu, reikia rasti ryši tarp laidininke sukaupto krūvio ir jo potencialo. Šis ryšys randamas remiantis Gauso dèsniu.

Daugelis uždavinių, susijusių su elektromagnetinio lauko analize, yra sprendžiami baigtinių skirtumų laiko srityje metodu (Krukonis 2010; Krukonis, Urbanavičius 2011; Watanabe 2009).

Šiuo metu rinkoje yra daug specializuotų leidžiančių modeliuoti mikrobangų įtaisus programinės ịrangos paketų (PİP). Visų pirma kiekvienas iš mikrobangų įtaisų analizès PIP turi turèti šiuos įrankius (Hoefer 2003): ịtaiso struktūros braižymas, medžiagų savybių bei kraštinių sąlygų parinkimas, tinklelio sudarymas, analizès uždavinio sprendimas, rezultatų pateikimo bei atvaizdavimo.

Šiuo metu labiausiai paplitę elektromagnetinių uždavinių sprendimui skirti PĮP yra: AVR Microwave Office ${ }^{\circledR}$, CST Microwave Studio ${ }^{\circledR}$ (CST 2013), Sonnet $^{\circledR}$, QWED $^{\circledR}$, MAFIA $^{\circledR}$, SPICE $^{\circledR}$. Svarbiausias visus programinius paketus charakterizuojantis požymis yra naudojamas skaičiavimo metodas. Pavyzdžiui programų pakete Sonnet ${ }^{\circledR}$ naudojamas momentų metodas (Sonnet 2013). CST Microwave Studio ${ }^{\circledR} 2010$ taikomas baigtinių integralinių transformacijų arba 
baigtiniu skirtumų laiko srities metodai. MAFIA (angl. Solution of MAxwell's equations by the Finite-Integration-Algorithm) naudoja baigtiniu integraliniu algoritmu metodą. Sekančiuose skyriuose atlikdami imitacinius skaičiavimus rezultatus lyginsime su specializuotais Sonnet ${ }^{\circledR}$ ir CST Microwave Studio ${ }^{\circledR}$ programinès įrangos paketais gautais rezultatais.

\subsection{Nevienalyčių lètinimo sistemụ problemos}

Dauguma periodinių lètinimo sistemų yra nevienalytès. Periodinį nevienalytiškumą lemiančios priežastys gali būti įvairios: dielektrinių laikiklių naudojimas, spiralinès ar meandrinès sistemos elektrodo laido išlankstymas, kintančio pločio spiralès vijos ir kitos (Štaras et al. 2010).

Vienas iš svarbių lètinimo sistemu periodinius netolygumus lemiančių elementų yra lètinimo elektrodų dielektriniai laikikliai. Darbe (Burokas, Štaras 2004) taikant daugialaidžių linijų metodą bei atsižvelgiant, kad dielektrinių laikiklių matmenys nedideli, dèl jų atsirandantys talpinio pobūdžio netolygumai modeliuoti sutelktomis talpomis: dèl dielektrinių laikiklių gali padidèti talpos tarp gretimų vijų bei vijų ir ekranų.

Darbe (Daškevičius et al. 2007) teigiama, kad realios meandrinès sistemos yra nevienalytės struktūros. Šiame straipsnyje be dielektrinių laikiklių kaip periodinių netolygumų priežastis dar minima meandrinès sistemos elektrodo laido išlankstymas. Tuomet periodiškai kinta laidininko kryptis ir elektrinio lauko spinduliavimas (Mikučionis, Urbanavičius 2011). Šie netolygumai vadinami periodiniais nesimetriniais išilginès meandro ašies atžvilgiu netolygumais. Darbe (Daškevičius, Skudutis 2007) periodiški nesimetriniai netolygumai tirti daugialaidžių linijų metodu su talpomis, kurios prijungtos prie vienos vingio elektrodo pusès.

Darbe (Burokas, Štaras 2005) teigiama, kad norint sumažinti dispersiją ir banginès varžos priklausomybę nuo dažnio, reikia spiralinių ir meandrinių bègančiosios bangos kreipimo sistemų konstrukcijose padidinti ekranuojančiųjų sieneliu aukščius, kad šios sienelès jungtų apatinị ir viršutinį ekranus. Tuomet bus išvengta ryšio tarp vijų ir rezonansinių reiškinių trumpai sujungtose ilgosios linijos atkarpose. Tačiau tokių kreipimo sistemų ekranuojančiose sienelèse turi būti angos elektronų pluoštui. Teigiama, kad dèl šių angų atsiranda periodiniai signalinio trakto netolygumai ir lovelinés sistemos tampa nevienalytemis.

Nagrinejjant dvipradę spiralinę kreipimo sistemą buvo pastebèta, kad dèl vijos pločio kitimo sistema tampa nevienalyte. Darbe (Štaras, Burokas 2003) aptikta, kad dèl periodinių netolygumų spiralinè sistema ịgyja užtvarinio filtro savybes, kai dažnis aukštas ir fazès kampas $\theta$ tarp gretimų spiralès vijų įtampų 
arba srovių tampa artimas $\pi$. Panašūs rezultatai gaunami naudojant ir meandrines sistemas (Daškevičius, Skudutis 2007).

Visuose nagrinètuose darbuose pabrež̌iama, kad neigiamas periodinio nevienalytiškumo poveikis yra užtvarinès juostos formavimasis (Burokas, Štaras 2008). Nevienalytiškumo problema aktuali ir daugelio kitų periodinių sistemų atveju.

Kadangi periodinio nevienalytiškumo ịtaka virpesių perdavimui aktuali ir nepakankamai ištirta, ją būtina nagrinèti išsamiau - sudaryti apibendrintus nevienalyčių periodinių sistemų modelius ir ištirti nevienalyčių plačiajuosčių periodinių sistemų užtvarines savybes, atsižvelgiant, kad lètinimo sistemų modeliavimo rezultatus taip pat ịtakoja ir pasirinktas analizès metodas.

\subsection{Nevienalyčių lètinimo sistemų tyrimas taikant dirbtinių neuronų tinklus}

Sparčiai vystantis technologijoms mokslininkai vis dažniau susiduria su problemomis spręsdami sudètingus mikrobanginių ịtaisų modeliavimo, imitavimo ir optimizavimo uždavinius. Tradiciniai analitiniai ir skaitiniai metodai turi savo trūkumų. Analitiniai metodai reikalauja sudètingo matematinio modelio sudarymo, kiekvieną kartą modifikavus tiriamą lètinimo sistemą. Skaitiniai metodai reikalauja didelių kompiuterinių resursų. Pastebima, kad tradiciniai modeliai korektiškai skaičiuoja jau išvystytų struktūrų charakteristikų vertes, bet susiduriama su problemomis, kai bandoma analizuoti naujas struktūras. Vystantis technologijoms ir mikrobangų įtaisams atsirado poreikis ne tik naujų modelių, bet taip pat ir kompiuterinio modeliavimo algoritmų, kurie leistų paspartinti ir supaprastinti imitacinių skaičiavimų procesą.

XX a. devintajame dešimtmetyje, išaugus skaičiavimo technikos resursams, sudètingos konstrukcijos elektrodinaminių sistemų analizei vis dažniau pradèti taikyti skaitiniai metodai (Gurskas 1995; Urbanavičius et al. 2009; Sadiku 2009). Modeliuojant LS skaitiniais metodais analizė gali trukti labai ilgai - nuo dešimčių minučių iki dešimčių valandų (Ergul et al. 2011). Tačiau skaitinių metodų taikymas leidžia ịvertinti daugiau faktorių nei analitiniais metodais grịsti modeliai, pavyzdžiui, paviršinį ir galų efektus laidininkuose, nuostolius dielektrikuose ir elektrodų laikikliuose bei leidžia gauti pakankamai tikslius rezultatus (Pomarnacki, Urbanavičius 2009). Darbe (Pomarnacki et al. 2012) siūloma LS analizei taikyti daugialaidžių linijų ir skaitinių metodų derinius, taikant technologijos, leidžiančias paskirstyti uždavinius tarp asmeninių kompiuterių arba naudoti grafinius ar specialios paskirties mikroprocesorius (Nvidia 2012), leidžiančius išlygiagretinti skaičiavimus. 
Kitas būdas, leidžiantis paspartinti LS modeliavimo procesą, nenaudojant papildomos brangios įrangos, yra kompiuterizuoto projektavimo metodų, grịstų dirbtinių neuronų tinklais (DNT), taikymas. DNT metodai yra daug greitesni nei tradiciniai analitiniai ir skaitiniai metodai (Kabir et al. 2010) ir leidžia surasti ryšius tarp tiriamos sistemos parametrų net tuomet, kai sistemos matematinis modelis nèra aiškus (Ninomiya et al. 2008). Tai ypač aktualu projektuojant naujas sistemas. Be to, DNT metodai leidžia kiekvieno tyrimo metu išsaugoti tyrejo sukauptą patirti. Ši savybė ypač svarbi pakartotinai vykdant modelio analizę, parenkant vis kitus pradinius parametrus ar sprendžiant sintezès uždavinius.

Pirmieji matematiniai DNT modeliai mokslinejje spaudoje aptarti XX a. penktajame dešimtmetyje po to, kai neuro fiziologo Warren McCulloch ir matematiko Walter Pitts buvo įrodyta, kad naudojant dirbtini neuroną su slenkstinemis aktyvavimo funkcijomis galima sukurti ịrenginį, vykdantị bet kokią loginę funkciją. DNT pradèti plačiai naudoti tik nuo devintojo dešimtmečio vidurio, išradus greitus ir galingus neuronu tinklu mokymo mechanizmus. Šiuo metu DNT naudojami tokiose žmogaus veiklos srityse kaip signalų analizė, triukšmo eliminavimas, duomenų klasifikavimas, sistemų modeliavimas ir identifikavimas, prognozè bei kontrolè (Kabir et al. 2010).

DNT - tai dirbtinio intelekto sistemos, sukurtos imituoti žmogaus smegenu biologinès nervų sistemos veiklą: mokymąsi, mąstymą, informacijos saugojimą, atgaminimą ir atpažinimą (Navakauskas 2000). Neuronų tinklų teorinis pagrindas yra paremtas universalia priartejimo teorija, kuri teigia, kad neuronu tinklas su bent vienu paslèptuoju sluoksniu gali aproksimuoti bet kokią netiesinę netrūkią daugiamatę funkciją bet kokiu norimu tikslumu (Kabir et al. 2008). Dirbtinių neuronų tinklai taikomi tiesinio ir netiesinio įvertinimo, klasifikacijos, grupavimo uždaviniams spręsti. Priklausomai nuo sprendžiamos užduoties neuronų tinklai gali būti taikomi analizès (Tomar et al. 2010; Singh et al. 2011) ir sintezès (Bellil et al. 2006; Kabir et al. 2008) uždaviniams spręsti. Sprendžiant sintezès uždavinị svarbu išvengti unikalių sprendinių pasikartojimo problemos.

Dèl šių priežasčiu DNT naudojimo sritis labai plati: kalbos apdorojimas, vaizdų apdorojimas, signalu apdorojimas, finansų bei ekonomikos modeliavimas, objektų atpažinimas. Vis dažniau DNT taikomi ir mikrobangų itaisų modeliavimo srityje: bangolaidžių komponentai (Plonis et al. 2010); filtrai (Yahia et al. 2010; Michalski 2010); antenų modeliai (Malathi et al. 2009); netiesinių įtaisų modeliai (Schreurs et al. 2002); netiesinių mikrobangų grandynų optimizavimas (Rizzoli et al. 2004) ir t. t.

Visi išvardinti DNT privalumai yra aktualūs modeliuojant spiralines ir meandrines lètinimo sistemas. Taikant analitinius iteracinius daugialaidžių linijų metodus ir skaičiuojant lètinimo sistemos lètinimo koeficiento ir iejjimo varžos dažninès charakteristikas susiduriama su teisingų sprendinių atrankos problema. Teisingų sprendinių atrankos problema atsiranda dẻl nevienareikšmių sprendi- 
nių, kadangi ị lètinimo sistemų dispersinių lygčių išraiškas patenka trigonometrinès funkcijos. Tokiu atveju teisingu sprendiniu galima palaikyti ne nulinės, o minus pirmosios erdvinès harmonikos vèlinimą periodinèje lètinimo sistemoje (Štaras et al. 2012). Ši problema šiuo metu sprendžiama taikant iteracinius priartejjimo metodus. Iteraciniai metodai yra lèti ir reikalauja pastovaus tyrejo įsikišimo. Tokio tipo problemos įvardijamos kaip klasifikavimo uždaviniai ir gali būti sprendžiamos taikant DNT (Plonis et al. 2010).

Sprendžiant klasifikavimo uždavinius ieškoma sąsajų tarp įvesties ir išvesties parametrų rinkinių. Daugelyje mikrobangu ịtaisus analizuojančių darbų neuronų tinklai taikomi juodosios děžès pagrindu. Naudotojai dažniausiai turi žinoti, kaip surinkti ir parengti duomenis ir kaip interpretuoti gautus rezultatus, nenagrinejjant sistemos matematinio modelio.

DNT tampa ypač aktualūs, kalbant apie automatizuotą plačiajuosčių lètinimo ịtaisu projektavimą (Štaras et al. 2010). Vykdant automatizuotą lètinimo itaisų projektavimą projektuotojo ịsikišimas būna minimalus. Tokiu atveju tinka mokymo be mokytojo DNT (Bui et al. 2009).

Apibendrinant galima teigti, kad iteracinius analitinius ir skaitinius metodus galima pakeisti dirbtinių neuronų tinklų metodais. DNT atitikimas etaloniniams analitiniams ir skaitiniams iteraciniams metodams priklauso nuo teisingo neuronų tinklo konkrečiam uždaviniui parinkimo, teisingos neuronų tinklo struktūros parinkimo, teisingo mokymo algoritmo parinkimo. Mokymo metu tikslesni mokymo algoritmai reikalauja daugiau laiko apmokymams, bet garantuoja geresnius rezultatus, todèl ne vienas autorius akcentuoja, kad labai tikslius mokymo algoritmus reiktų naudoti tuomet, kai apmokytas neuronų tinklas bus daug kartų panaudotas, siekiant atpirkti mokymo sąnaudas.

\subsection{Autoriaus indèlis ị problemos sprendimą}

Spiralines ir meandrines LS tyre profesoriai habil. dr. S. Štaras, R. Kirvaitis, R. Martavičius, J. Skudutis, profesorius V. Urbanavičius, docentai dr. A. Gurskas, V. Daškevičius ir kiti. Lètinimo sistemos Lietuvoje intensyviai tiriamos nuo XX a., septintojo dešimtmečio. S. Štaras tyrè spiralinès ir meandrinès konstrukcijos lètinimo ir kreipimo sistemas. R. Martavičius nagrinëjo plačiajuostes planarines LS. V. Urbanavičius tyrè mikrojuostelines vèlinimo linijas, taikydamas skaitinius metodus. A. Gurskas meandrinių sistemų tyrimus atliko, taikydamas sklaidos matricų metodus. J. Skudutis ir V. Daškevičius tirdami spiralinès ir meandrinès konstrukcijos lètinimo sistemas taikè universaliają programinę ịrangą. R. Kirvaitis tyrè elektrodinaminių vèlinimo linijų savybes.

Aukščiau minèti tyrejai pastebejo, kad tam tikrais atvejais LS vyksta rezonansai. Disertacijos autorius tirs spiralinių ir meandrinių konstrukcijų LS rezo- 
nansinius reiškinius, lemiančius užtvarinès juostos formavimąsi, ir pritaikys dirbtinių neuronų tinklus LS automatizuotai analizei ir projektavimui.

\subsection{Pirmojo skyriaus išvados ir disertacijos uždavinių formulavimas}

Atlikus analitinę literatūros apžvalgą galima teigti, kad:

1. Spiralinès ir meandrinès konstrukcijos lètinimo sistemos dažnai taikomos įvairios paskirties mikrobangu įtaisuose.

2. Dauguma periodinių lètinimo sistemų yra nevienalytès. Periodinių nevienalytiškumų priežastys gali būti įvairios: dielektrinių laikiklių įtaka, spiralinio arba meandrinio laidininko konstrukcija ir kitos.

3. Dèl periodinių netolygumų lètinimo sistemos pasižymi rezonansiniais reiškiniais, kuriuos itakojantys veiksniai nèra detaliai ištirti ir nèra sukurta išsami šių reiškinių tyrimo metodika.

4. Taikant dirbtinių neuronų tinklų metodus galima sumažinti lètinimo sistemų tyrimams reikalingus kompiuterinius ir laiko išteklius. Iki šiol nèra sukurta lètinimo sistemų analizès ir sintezès metodų, grịstų dirbtinių neuronų tinklų taikymu.

Tikslinga tirti sudètingų turinčių periodinių netolygumų spiralinių ir meandrinių lètinimo sistemų savybes ir jų analizès metodus, siekiant patobulinti turinčias periodinių netolygumų létinimo sistemas ir jų automatizuoto projektavimo metodus, taikant dirbtinių neuronų tinklus. Šiam tikslui pasiekti turi būti išspręsti uždaviniai:

1. Ištirti periodinių netolygumų įtaką nevienalyčių periodinių lètinimo sistemų savybèms.

2. Ištirti spiralinių, meandrinių ir hibridinių lètinimo sistemų, turinčių periodinių netolygumų, savybes.

3. Sudaryti lètinimo sistemų, turinčių periodinių netolygumų, automatizuotos analizès ir projektavimo algoritmus, taikant dirbtinių neuronų tinklus.

4. Imitacinių skaičiavimų būdu patikrinti siūlomų metodų veiksmingumą. 


\section{2}

\section{Nevienalyčių periodinių sistemų savybių tyrimas}

Šiame skyriuje tiriamos nevienalyčių plačiajuosčių periodinių sistemų užtvarinès savybès ir jas lemiantys reiškiniai. Nevienalyčių periodinių sistemų savybių tyrimui taikomas baigtinio ilgio ilgosios linijos modelis. Ilgosios linijos modelis analizuojamas ilgujų linijų bei matriciniu metodais. Gauti rezultatai lyginami su specializuotu programų paketu CST Microwave Studio ${ }^{\mathbb{R}}$ skaitiniais metodais gautais rezultatais.

Skyriaus tematika paskelbti du autoriaus straipsniai (Katkevičius, Štaras 2009; Katkevičius 2010).

\subsection{Sistemų dažninių savybių tyrimas ilgụjų linijų metodu}

Darbe (Štaras et al. 2012) nagrinètos nevienalyčių periodinių plačiajuosčių lètinimo sistemų savybès. Pastebėta, kad jų charakteristikos skiriasi nuo vienalyčių lètinimo sistemų charakteristikų - dèl nevienalytiškumo kinta lètinimo koeficiento ir iejjimo varžos charakteristikos ir lètinimo sistema įgyja užtvarinio filtro savybių. 
Siekdami giliau atskleisti reiškinius, lemiančius užtvarines savybes ir šių savybių priklausomybę nuo periodinių netolygumų, šiame poskyryje ištirsime baigtinio ilgio ilgosios linijos, turinčios periodinių netolygumų, iejjimo varžos priklausomybę nuo dažnio ilgụjų linijų metodu.

\subsection{1. lëjimo varžos skaičiavimo algoritmas}

Signalų trakto, kuriame ijungta linija su periodiniais netolygumais, schema pavaizduota 2.1 paveiksle. Linija prijungta prie virpesių šaltinio, kurio elektrovara $\underline{E}$ ir vidaus varža $\underline{Z}_{i}$. Linija turi $n$ periodų. Periodas sudarytas iš dviejų vienalyčių atkarpų, kurių ilgiai $-l_{1}$ ir $l_{2}$, o banginès varžos $-\underline{Z}_{\mathrm{B} 1}$ ir $\underline{Z}_{\mathrm{B} 2}$. Gale linija apkrauta apkrova, kurios varža $\underline{Z}_{\mathrm{a}}$.

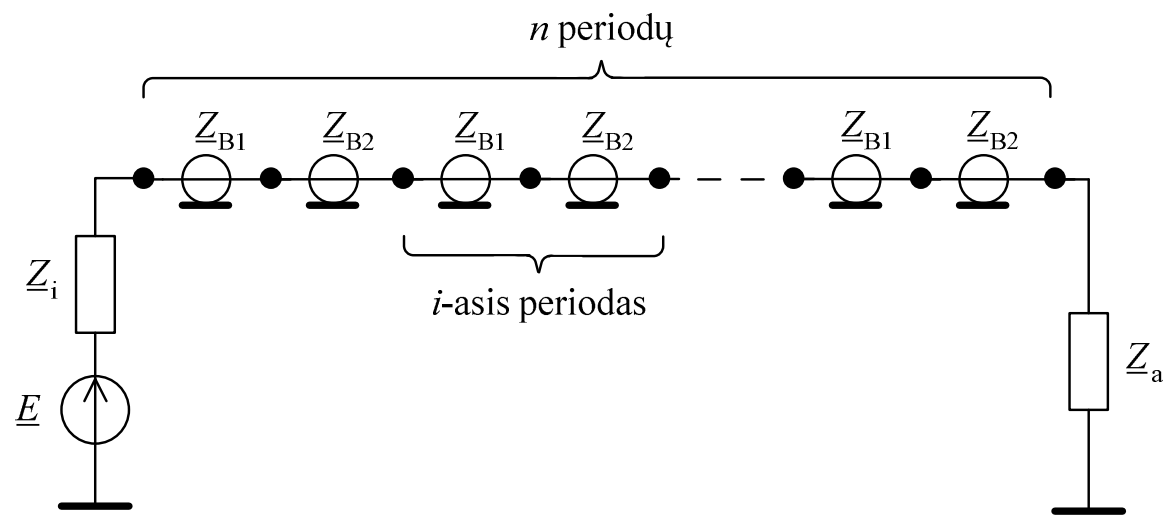

2.1 pav. Signalu trakto su linija, turinčia periodinių netolygumų, schema

Fig. 2.1. The scheme of the signal tract with the line having periodical inhomogeneities

Aptarsime linijos įejimo varžos dažninių charakteristikų skaičiavimą ilgujų liniju metodu. Analizuodami skaičiavimo rezultatus atskleisime linijos charakteristikų priklausomybes nuo periodų skaičiaus ir periodą sudarančių vienalyčių atkarpų parametrų.

Atspindžio koeficientu vadinamas atsispindejjusiosios ir krintančiosios bangų kompleksinių amplitudžių santykis linijos galuose arba nevienalyčių sričių ribose. Atspindžio koeficientas kiekybiškai įvertina linijos suderinimą su apkrova ir yra apskaičiuojamas pagal įtampą arba pagal srovę. Atspindžio koeficientas išreiškiamas formule:

$$
\underline{P}_{\mathrm{g}}=\left|\underline{P}_{\mathrm{g}}\right| \cdot \mathrm{e}^{\mathrm{j} / \mathrm{g}}=\frac{\underline{U}_{\mathrm{g}}-\underline{I}_{\mathrm{g}} \underline{Z}_{\mathrm{B}}}{\underline{U}_{\mathrm{g}}+\underline{I}_{\mathrm{g}} \underline{Z}_{\mathrm{B}}}=\frac{\underline{Z}_{\mathrm{a}}-\underline{Z}_{\mathrm{B}}}{\underline{Z}_{\mathrm{a}}+\underline{Z}_{\mathrm{B}}},
$$


čia $\underline{U}_{\mathrm{g}}$ - itampa linijos gale; $\underline{I}_{\mathrm{g}}$ - srovè linijos gale; $\underline{Z}_{\mathrm{B}}$ - linijos banginè varža; $\underline{Z}_{\mathrm{a}}$ - linijos apkrovos varža; $\left|\underline{P}_{\mathrm{g}}\right|$ - atspindžio koeficiento modulis; $\Psi_{\mathrm{g}}$ - fazès skirtumo tarp atspindètosios ir krintančiosios bangų kampas.

Priklausomai nuo $\left|\underline{P}_{\mathrm{g}}\right|$ dydžio ilgojoje linijoje galimi bègančiosios bangos ir interferencijos režimai. Pastarasis dar dalijamas i visiško ir dalinio atspindžio režimus. Nagrinejjamas modelis bus suderinamas esant mišriųjų bangų režimui, t. y. kai apkrova tik iš dalies absorbuoja krintančiosios bangos energiją ir yra nelygi linijos banginei varžai $\left(\underline{Z}_{\mathrm{a}} \neq \underline{Z}_{\mathrm{B}}\right)$.

Ilgosios linijos ièjimo varža $\underline{Z}_{\mathrm{IN}}(y)$ vadinamas itampos ir srovès kompleksinių amplitudžių santykis nagrinèjamame jos skerspjūvyje $y$.

$$
\underline{Z}_{\mathrm{IN}}(y)=\frac{\underline{U}(y)}{\underline{I}(y)}=\underline{Z}_{\mathrm{B}} \frac{1+\underline{P}(y)}{1-\underline{P}(y)},
$$

čia $\underline{U}(y)$ - ìtampa linijos skerspjūvyje $y ; \underline{I}(y)$ - srovė linijos skerspjūvyje $y$; $\underline{P}(y)$ - atspindžio koeficientas linijos pjūvyje $y ; \underline{Z}_{\mathrm{B}}-$ linijos banginè varža.

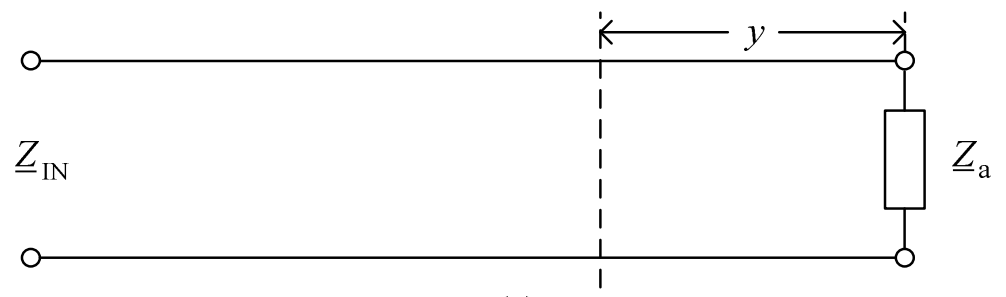

(a)

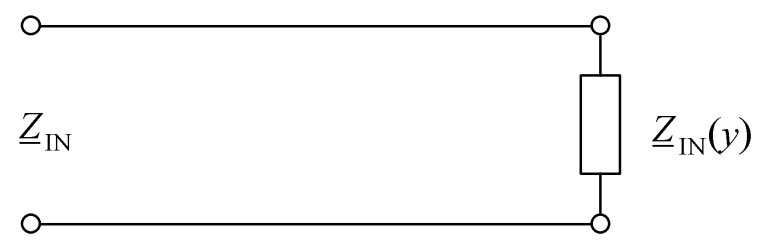

(b)

2.2 pav. $y$ ilgio linijos atkarpos pakeitimas jos iẹjimo varža (Vainoris 2004): (a) ilgojoje linijoje pažymèta $y$ ilgio atkarpa; (b) $y$ ilgio atkarpa pakeista jos įejjimo varža

Fig. 2.2. Replacement of $y$ length section of the line with its input impedance (Vainoris 2004): (a) transmission line with marked $y$ length section; (b) $y$ length of the line replaced with it's input impedance

Tai reiškia, kad generatoriaus darbo režimo apskaičiavimui visą liniją galima pakeisti dvipoliu, kurio kompleksinè varža lygi linijos ièjimo varžai (2.2 pav. a). Linijos iejjimo varžą galima apskaičiuoti ir bet kuriame linijos 
skerspjūvyje, $y$ ilgio linijos atkarpą su apkrova $\underline{Z}_{\mathrm{a}}$ pakeitus sutelktaja varža $\underline{Z}_{\text {IN }}(y)$ (2.2 pav. b). Po tokio pakeitimo darbo režimas sutrumpintoje linijoje išliks nepakitęs. Taip pat nepasikeis generatoriaus darbo režimas.

Ilgosios linijos įejjimo varža išreiškiama formule (Vainoris 2004):

$$
\underline{Z}_{\mathrm{IN}}(y)=\underline{Z}_{\mathrm{B}} \frac{\underline{Z}_{a}+\mathrm{j} \cdot \underline{Z}_{\mathrm{B}} \cdot \tan (\beta y)}{\underline{Z}_{\mathrm{B}}+\mathrm{j} \cdot \underline{Z}_{a} \cdot \tan (\beta y)},
$$

čia $\underline{Z}_{\mathrm{a}}$ - apkrovos varža; $\underline{Z}_{\mathrm{B}}$ - linijos vienalytès atkarpos banginè varža; $y$ - koordinatè, atskaitoma nuo linijos galo, prie kurio prijungta apkrova; $\beta$-nagrinejjamos atkarpos fazès koeficientas.

Kai liniją sudaro $n$ periodu ir periodas sudarytas iš dviejų vienalyčiu atkarpu (2.1 pav.), iejjimo varžą galime rasti taikant 2.3 paveiksle pateiktą skaičiavimo algoritmą.

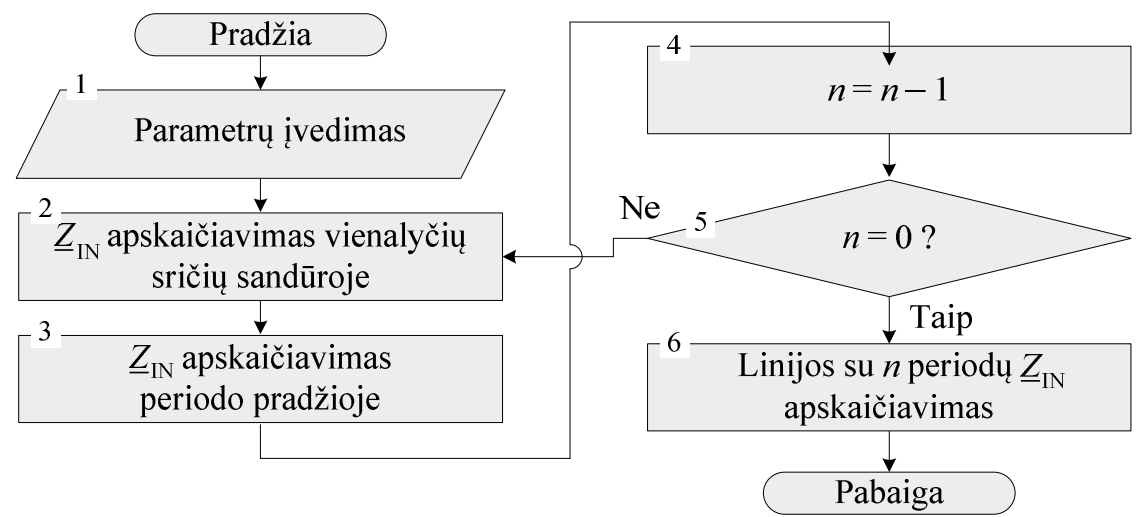

2.3 pav. $n$ periodų linijos ịejimo varžos skaičiavimo algoritmas

Fig. 2.3. The calculation algorithm of the input impedance of $n$ periods line

Skaičiavimai (2.3 pav.) pradedami ịvedant linijos parametrus: periodo ilgi, vienalyčių atkarpų ilgius, elektromagnetinès bangos sklidimo greičius atkarpose, atkarpų banginių ir apkrovos varžų vertes bei periodų skaičių linijoje (1 blokas). Toliau pradedamas iejjimo varžos skaičiavimo ciklas. İejimo varža skaičiuojama dviejuose linijos periodo taškuose: vienalyčių sričių sandūroje (2 blokas) ir vèliau - linijos periodo pradžioje (3 blokas). İejimo varžos skaičiavimai nuosekliai vykdomi kiekviename linijos periode, kol pasiekiama linijos pradžia (4-5 blokai). Tuomet pirmojo linijos periodo iejjimo varža prilyginama linijos iejjimo varžai (6 blokas). 


\subsection{2. lejjimo varžos skaičiavimo rezultatai}

Linijos su periodiniais netolygumais skaičiavimo rezultatai, gauti taikant ilguju linijų tyrimo metodiką, pateikti $2.4-2.7$ paveiksluose. Siekiant vaizdumo 2.4 paveikslo grafikuose pateiktos iejjimo varžos charakteristikos, kai linija sudaryta iš 1,2 ir 4 periodų, o vienalyčių sričių banginių varžų santykis bei vienalyčiu sričių ilgių santykis nekinta. 2.5 paveiksle pateiktos iejjimo varžos charakteristikos, kai periodų skaičius yra pastovus ir lygus 4, vienalyčių sričių ilgių santykis nekinta, o kinta vienalyčių sričių banginių varžų santykis, kuris lygus 1; 1,$3 ; 1,5$. Tiriant dažninių charakteristikų priklausomybę nuo sistemos periodo banginiu varžų santykio banginè varža $Z_{\mathrm{B} 1}$ kito $40-50 \Omega$, о $Z_{\mathrm{B} 2}$ kito $50-60 \Omega$ ribose. 2.6 paveiksle pateiktos iejjimo varžos charakteristikos, kai kinta vienalyčių sričių ilgių santykis $1 ; 4 ; 19$, o periodų skaičius lygus 4 ir banginès varžos lygios $Z_{\mathrm{B} 1}=40 \Omega$ bei $Z_{\mathrm{B} 2}=60 \Omega$.

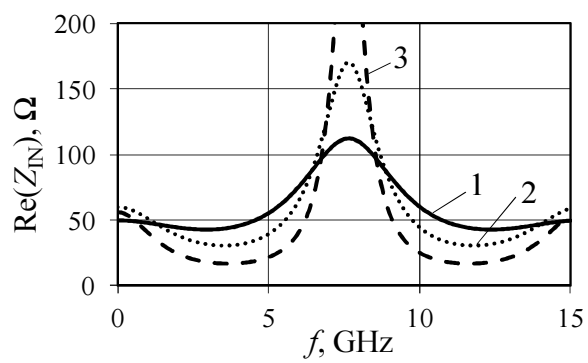

(a)

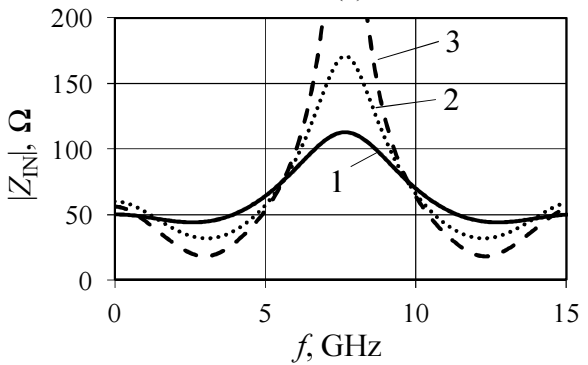

(c)

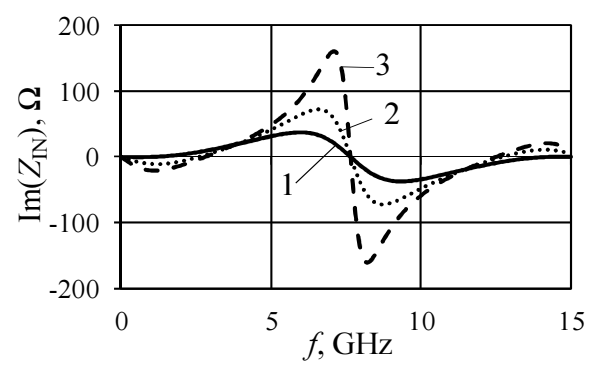

(b)

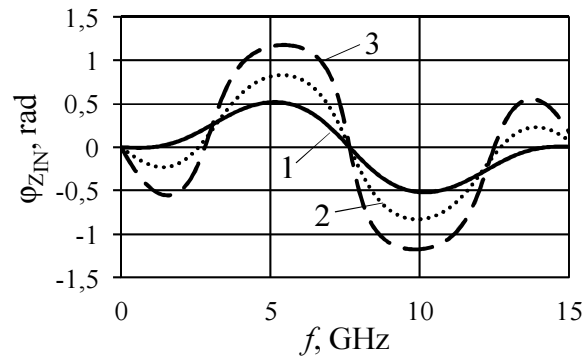

(d)

2.4 pav. Ilgosios linijos įėjimo varžos realiosios (a), menamosios (b) dedamujų, modulio (c) ir fazès (d) dažninės charakteristikos, kai $Z_{\mathrm{B} 1}=40 \Omega, Z_{\mathrm{B} 2}=60 \Omega$,

$$
l_{1}=l_{2}=10 \mathrm{~mm} \text { ir: } 1-n=1 ; 2-n=2 ; 3-n=4 \text { periodai }
$$

Fig. 2.4. Active (a), reactive (b), module (c) and argument (d) of imput impedance versus frequency of the transmission line at $Z_{\mathrm{B} 1}=40 \Omega, Z_{\mathrm{B} 2}=60 \Omega, l_{1}=l_{2}=10 \mathrm{~mm}$ and: $1-n=1 ; 2-n=2 ; 3-n=4$ periods 
Linijos periodo ilgis visų tyrimų metu buvo pastovus ir lygus $0,02 \mathrm{~m}$. Buvo priimta, kad elektromagnetinès bangos sklidimo greičiai linijos atkarpose lygūs šviesos greičiui, o virpesių šaltinio ir apkrovos varžos $-50 \Omega$.

Iš 2.4 paveikslo matyti, kad bendruoju atveju linijos iejjimo varža yra kompleksinè. Jos realioji, menamoji dalys ir modulis priklauso nuo dažnio. Modulis tampa maksimalus, kai elektromagnetinès bangos ilgis yra dvigubai didesnis nei linijos periodo ilgis $l_{\mathrm{p}}$, t. y., kai atitinka sąlygą $l_{\mathrm{p}}=\lambda / 2$. Tada ties dažniu $f=v / \lambda=v / 2 l_{\mathrm{p}}$ (čia $v$ - elektromagnetinès bangos sklidimo greitis linijoje) įejjimo varža yra grynai aktyvioji. Padidinus periodų skaičių nuo 1 iki 4 iejjimo varžos modulio maksimalios vertes išaugo tris kartus, nuo $112 \Omega$ iki $332 \Omega$.

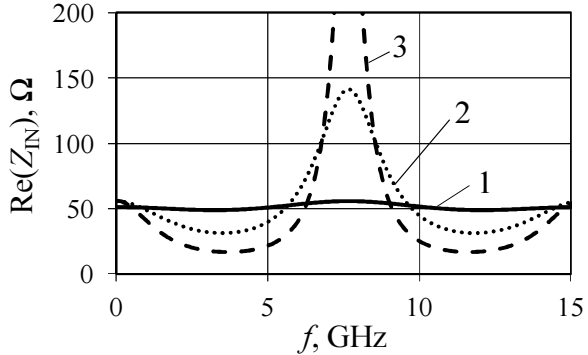

(a)

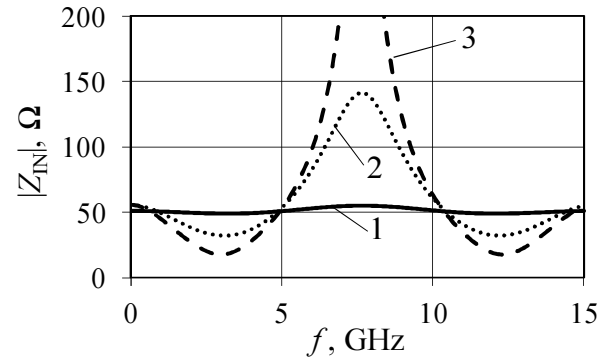

(c)

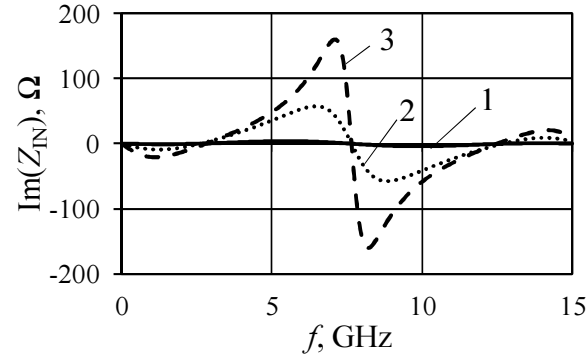

(b)

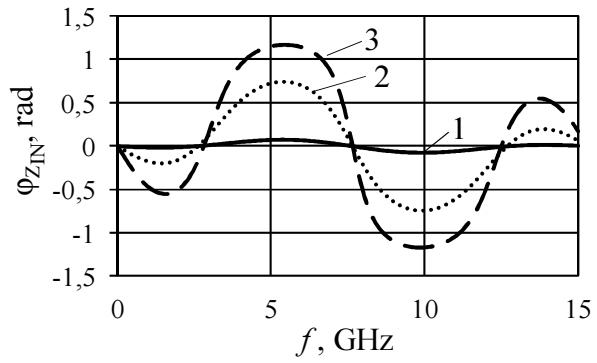

(d)

2.5 pav. Ilgosios linijos ịjimo varžos realiosios (a), menamosios (b) dedamujjų, modulio (c) ir fazès (d) dažninès charakteristikos, kai $l_{1}=l_{2}=10 \mathrm{~mm}, n=4$, $\left(Z_{\mathrm{B} 1}+Z_{\mathrm{B} 2}\right) / 2=50 \Omega$ ir: $1-Z_{\mathrm{B} 1} / Z_{\mathrm{B} 2}=1 ; 2-Z_{\mathrm{B} 1} / Z_{\mathrm{B} 2}=1,3 ; 3-Z_{\mathrm{B} 1} / Z_{\mathrm{B} 2}=1,5$

Fig. 2.5. Active (a), reactive (b), module (c) and argument (d) of imput impedance versus frequency of the transmission line at $l_{1}=l_{2}=10 \mathrm{~mm}, n=4,\left(Z_{\mathrm{B} 1}+Z_{\mathrm{B} 2}\right) / 2=50 \Omega$ and then: $1-Z_{\mathrm{B} 1} / Z_{\mathrm{B} 2}=1 ; 2-Z_{\mathrm{B} 1} / Z_{\mathrm{B} 2}=1.3 ; 3-Z_{\mathrm{B} 1} / Z_{\mathrm{B} 2}=1.5$

Iš 2.5 paveikslo rezultatų matyti, kad, nors tyrème $\underline{Z}_{\text {IN }}$ priklausomybę nuo vienalyčių sričiu banginių varžų santykio, gauti rezultatai panašūs i gautuosius 2.4 paveiksle. Bendruoju atveju linijos iejejimo varža yra kompleksinè. Modulis tampa ekstremalus, kai elektromagnetinès bangos ilgis tampa dvigubai didesnis 
nei linijos periodo ilgis. Ties dažniu $f=v / 2 l_{\mathrm{p}}$ ièjimo varža yra grynai aktyvioji. Be to įejjimo varžos $\underline{Z}_{\mathrm{IN}}$ kitimas didesnis, kai didesnis linijos vienalyčių sričių banginių varžų santykis. Didinant linijos vienalyčių sričių banginių varžų santykị nuo 1 iki 1,5 iejjimo varžos modulio maksimumai išaugo beveik 7 kartus nuo $55,5 \Omega$ iki $380 \Omega$.

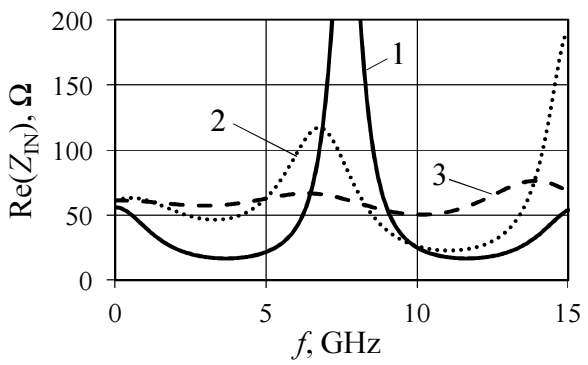

(a)

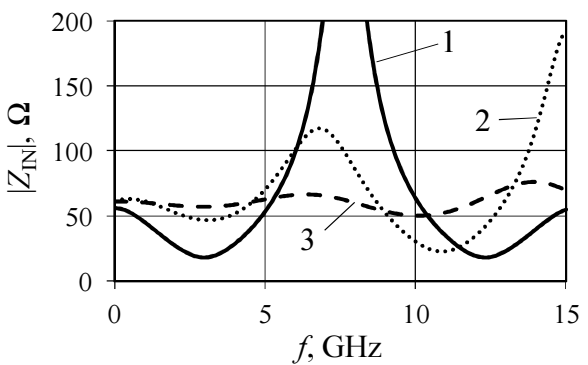

(c)

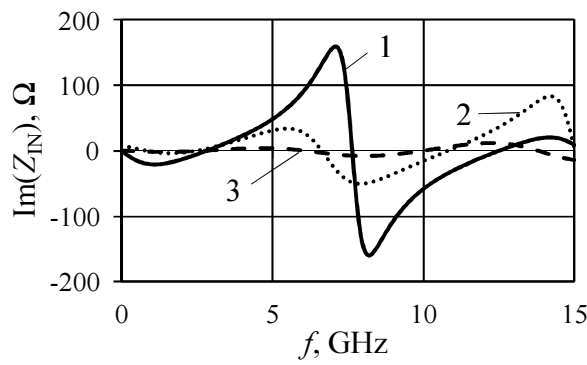

(b)

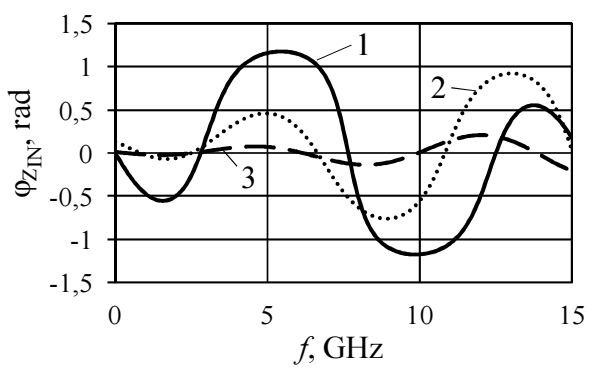

(d)

2.6 pav. Ilgosios linijos ièjimo varžos realiosios (a), menamosios (b) dedamujų, modulio (c) ir fazès (d) dažninès charakteristikos, kai $Z_{\mathrm{B} 1}=40 \Omega, Z_{\mathrm{B} 2}=60 \Omega, n=4$ ir kai : $1-l_{1} / l_{2}=1 ; 2-l_{1} / l_{2}=4 ; 3-l_{1} / l_{2}=19$

Fig. 2.6. Active (a), reactive (b), module (c) and argument (d) of imput impedance versus frequency of the transmission line at $Z_{\mathrm{B} 1}=40 \Omega, Z_{\mathrm{B} 2}=60 \Omega, n=4$, and then:

$$
1-l_{1} / l_{2}=1 ; 2-l_{1} / l_{2}=4 ; 3-l_{1} / l_{2}=19
$$

Iš 2.6 paveikslo matyti, kad linijos įejjimo varža yra kompleksinè ir modulis tampa maksimalus, kai elektromagnetinès bangos ilgis tampa dvigubai didesnis nei linijos periodo ilgis. İejimo varžos kitimas didejja, kai vienalyčių atkarpų ilgių santykis artejja prie vieneto. Beje kai $l_{1} \neq l_{2}$, dèl periodinių netolygumų iejjimo varžos modulio maksimumai atsiranda ir ties kartotiniais $m f_{\mathrm{c}}$ dažniais (kai periode telpa sveikasis pusbangių skaičius $m$ ). Mažèjant linijos vienalyčių sričių ilgių santykiui nuo 19 iki 1, t. y. vienalyčių sričių ilgių santykiui artejjant prie vieneto, ịejjimo varžos modulio maksimumai ties centriniu dažniu išauga 8 kartus nuo $47 \Omega$ iki $380 \Omega$. 
2.4-2.6 paveikslų rezultatai gauti esant kintančiam linijos ilgiui ir pastoviam periodo ilgiui. 2.7 paveiksle pateikti rezultatai, kai linijos ilgis yra pastovus, o periodo ilgis kinta. Skaičiavimai vykdyti pasirinkus 1, 2 ir 4 periodus, kai vienalyčių sričių banginès varžos buvo pastovios ir lygios $Z_{\mathrm{B} 1}=40 \Omega$ bei $Z_{\mathrm{B} 2}=60 \Omega$, o vienalyčių sričių ilgių santykis nekito $l_{1}=l_{2}$.

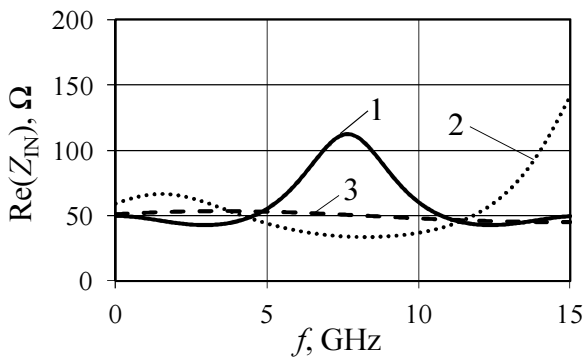

(a)

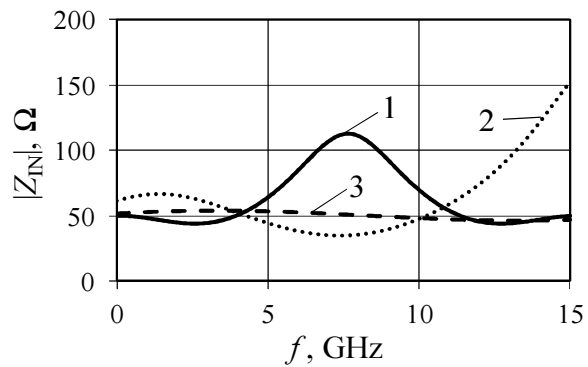

(c)

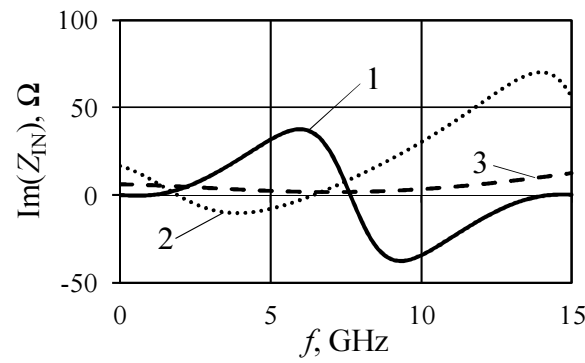

(b)

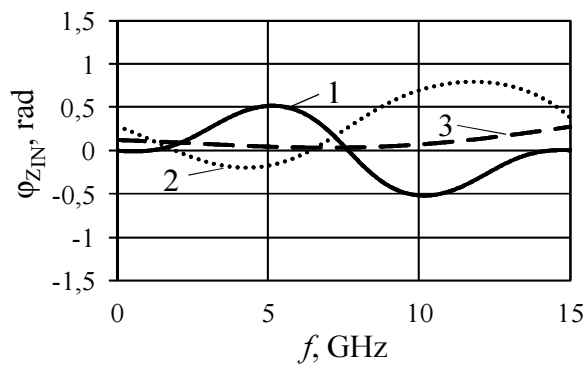

(d)

2.7 pav. Ilgosios linijos iejjimo varžos realiosios (a), menamosios (b) dedamujų, modulio (c) ir fazès (d) dažninès charakteristikos, kai $Z_{\mathrm{B} 1}=40 \Omega, Z_{\mathrm{B} 2}=60 \Omega, l_{1}=l_{2}$ ir kinta periodo ilgis bei kai: $1-n=1 ; 2-n=2 ; 3-n=4$ periodai

Fig. 2.7. Active (a), reactive (b), module (c) and argument (d) of imput impedance versus frequency of the transmission line at $Z_{\mathrm{B} 1}=40 \Omega, Z_{\mathrm{B} 2}=60 \Omega, l_{1}=l_{2}$ and varies the length of the period and then: $1-n=1 ; 2-n=2 ; 3-n=4$ periods

Iš gautų rezultatų matyti, kad kiekvieną kartą dvigubai didinant periodų skaičių, gauname ketvirtis buvusios iejjimo varžos charakteristikos, t. y. iejjimo varžos dažninès charakteristikos periodas dideja (2.7 pav.). Detalesni tyrimai su kintančiu periodų ilgiu atliekami nebuvo.

Taigi, didejant linijos periodiniams netolygumams - didejjant vienalyčių sričių banginių varžų santykiui, vienalyčių sričių ilgių santykiui artëjant prie vieneto ir didejant nevienalyčių periodų skaičiui - ilgoji linija dèl atspindžių nuo vienalyčių sričių ir jų sukeltų rezonansinių reiškinių igauna užtvarinio filtro sa- 
vybes, ko pasekoje ties užtvarine juosta didejja iejjimo varžos $\underline{Z}_{\mathrm{IN}}$ maksimalios vertès.

\subsection{Sistemų dažninių savybių tyrimas matricų metodu}

Šiame poskyryje nagrinėsime linijų su periodiniais netolygumais dažnines amplitudès bei fazès charakteristikas.

Minètų charakteristikų skaičiavimui galima taikyti ịvairius metodus (Gorbunova et al. 2011; Watanabe 2009). Nagrinejant linijas, sudarytas iš daugelio atkarpu, geriausiai tinka matriciniai metodai (Soluch 2012; Ye et al. 2010).

\subsubsection{Skaičiavimų algoritmas matricų metodu}

Matriciniai skaičiavimai naudojami tuomet, kai mikrobangų grandinėms projektuoti bei analizuoti elektrodinamikos matematinis aparatas yra pernelyg sudètingas. Mikrobangų grandinėms bandoma taikyti elektrinių grandinių teorijos metodus, sukurtus žemesniujų dažnių grandinèms. Bendroje grandinių teorijoje bet kokia grandinès dalis ar jos įtaisas vaizduojami ekvivalentiniu poriniu daugiapoliu. Pasyviniame tiesiniame daugiapolyje elektriniai virpesiai aprašomi tiesinèmis diferencialinèmis lygtimis su pastoviais koeficientais, o stacionarieji procesai - algebrinèmis Kirchhofo lygčių sistemomis kompleksinèms amplitudèms. Pastarujjų lygčių sprendimui ir grandinių analizei bei sintezei ir yra taikomas matricu metodas.

Mikrobangų grandinių matricų teorijoje pagrindinis analizès objektas dažniausiai būna keturpolis (2.8 pav.). Keturpolis - tai elektrinis itaisas su dviem gnybtų poromis, kuriose išmatuotos arba apskaičiuotos srovès ir įtampos lemia jo išorines elektrines charakteristikas, t. y. jo įejimų elektrinių parametrų sąryšius su išèjimais.

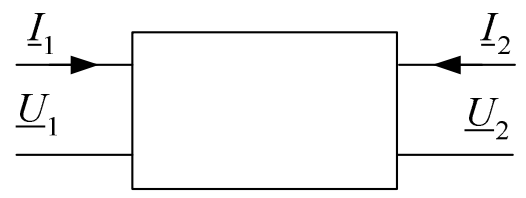

2.8 pav. Mikrobangų keturpolio schema

Fig. 2.8. The scheme of the microwave four-port 
Keturpolį, kaip perdavimo grandinę, galima apibūdinti kompleksiniu perdavimo koeficientu. Galima skaičiuoti itampos $\underline{K}_{U}(\omega)$, srovès $\underline{K}_{I}(\omega)$ arba galios $\underline{K}_{S}(\omega)$ kompleksini perdavimo koeficientą. Iš šių trijų dažniausiai naudojamas kompleksinis įtampos perdavimo koeficientas:

$$
\underline{K}_{U}(\omega)=K_{U}(\omega) \cdot \mathrm{e}^{\mathrm{j} \phi(\omega)},
$$

čia $K_{U}(\omega)$ - dažninè amplitudès charakteristika; $\phi(\omega)$ - dažninè fazès charakteristika.

Naudojant matricinį metodą gali būti taikoma viena iš šių matricų: $\boldsymbol{Z}-$ normuotų varžų; $\boldsymbol{Y}$ - normuotų laidžių; $\boldsymbol{A B C D}$ - apibendrintujjų parametrų; $\boldsymbol{B}-\beta$ parametrų; $\boldsymbol{H}-h$ parametrų; $\boldsymbol{G}-g$ parametrų.

Skaičiuojant LS perdavimo charakteristikas geriausia panaudoti $\boldsymbol{A B C D}$ matricą, kuri dažnai ịvardijama kaip perdavimo matrica (Zhou et al. 2008). Naudojant $\boldsymbol{A B C D}$ matricos metodą sunaudojama daug mažiau mašininio skaičiavimo laiko. Tai ypač pastebima skaičiuojant sudetingų periodinių sistemų parametrus.

2.8 paveiksle pavaizduoto keturpolio itampos bei srovès susiejamos lygčių sistema:

$$
\left\{\begin{array}{l}
\underline{U}_{1}=\underline{A} \cdot \underline{U}_{2}-\underline{B} \cdot \underline{I}_{2}, \\
\underline{I}_{1}=\underline{C} \cdot \underline{U}_{2}-\underline{D} \cdot \underline{I}_{2} .
\end{array}\right.
$$

Matriciniu pavidalu (2.5) formulè užrašoma:

$$
\left[\begin{array}{l}
\underline{U}_{1} \\
\underline{I}_{1}
\end{array}\right]=\left[\begin{array}{ll}
\underline{A} & \underline{B} \\
\underline{C} & \underline{D}
\end{array}\right] \cdot\left[\begin{array}{c}
\underline{U}_{2} \\
-\underline{I}_{2}
\end{array}\right] .
$$

Kai sistema sudètinga, ji skaidoma ir aprašoma paprastesniais keturpoliais, kurie vèliau pakopomis jungiami ị vieną visumą, sudauginant elementarių keturpolių $\boldsymbol{A B C D}$ matricas. Taip gaunama ekvivalentinio keturpolio $\boldsymbol{A B C D}$ matrica (2.9 pav.).

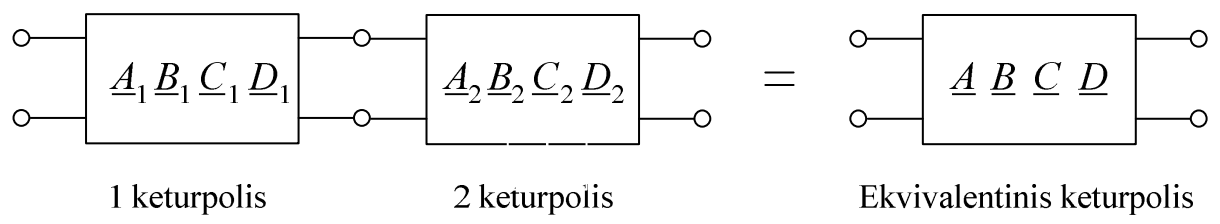

2.9 pav. Pakopinis keturpolių jungimas

Fig. 2.9. Cascaded circuit of four-ports 
Ekvivalentinès matricos koeficientai gaunami remiantis formulemis:

$$
\begin{aligned}
& \underline{A}=\underline{A}_{1} \cdot \underline{A}_{2}+\underline{B}_{1} \cdot \underline{C}_{2}, \\
& \underline{B}=\underline{A}_{1} \cdot \underline{B}_{2}+\underline{B}_{1} \cdot \underline{D}_{2}, \\
& \underline{C}=\underline{A}_{2} \cdot \underline{C}_{1}+\underline{C}_{2} \cdot \underline{D}_{1}, \\
& \underline{D}=\underline{B}_{2} \cdot \underline{B}_{1}+\underline{D}_{1} \cdot \underline{D}_{2} .
\end{aligned}
$$

Perdavimo linijos atkarpa gali būti modeliuojama ekvivalentiniu simetriniu T tipo keturpoliu, kurio $\boldsymbol{A B C D}$ matricos koeficientai išreiškiami formulemis:

$$
\begin{gathered}
\underline{A}_{i}=\underline{D}_{i}=\cosh \left(\underline{\gamma}_{i}\right), \\
\underline{C}_{i}=\frac{\sinh \left(\underline{\gamma}_{i}\right)}{Z_{\mathrm{B}}}, \\
\underline{B}_{i}=Z_{\mathrm{B}} \cdot \sinh \left(\underline{\gamma}_{i}\right),
\end{gathered}
$$

čia $\underline{\gamma}$-sklidimo konstanta; $l_{i}$ - linijos $i$-osios vienalytės srities ilgis.

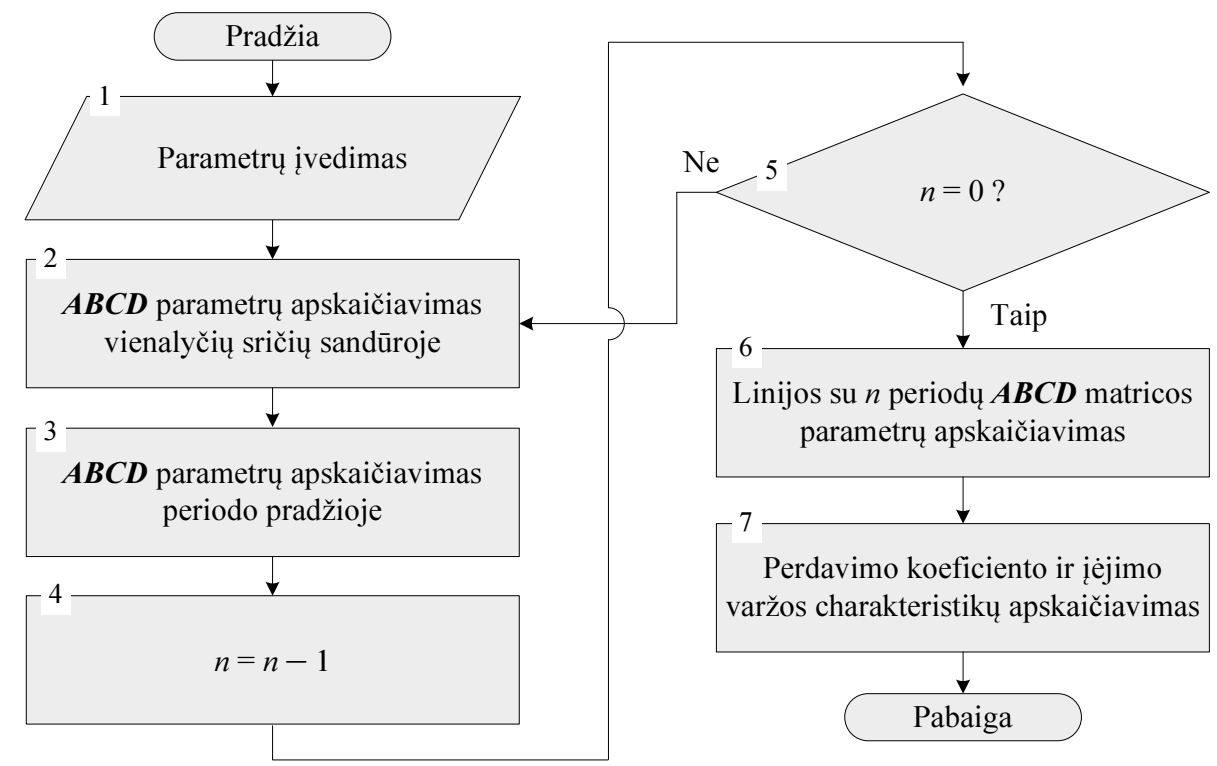

2.10 pav. $n$ periodų ilgosios linijos perdavimo koeficiento ir ịejjimo varžos charakteristikų skaičiavimo algoritmas

Fig. 2.10. The calculation algorithm of transfer coefficient and input impedance characteristics of $n$ periods transmission line 
Perdavimo linijos be nuostolių $\boldsymbol{A B C D}$ matricos koeficientuose hiperbolinès funkcijos keičiamos kampinèmis:

$$
\left[\begin{array}{ll}
\underline{A}_{i} & \underline{B}_{i} \\
\underline{C}_{i} & \underline{D}_{i}
\end{array}\right]=\left[\begin{array}{cc}
\cos \left(\beta l_{i}\right) & \mathrm{j} \cdot Z_{\mathrm{B}} \cdot \sin \left(\beta l_{i}\right) \\
\mathrm{j} \cdot \sin \left(\beta l_{i}\right) / Z_{\mathrm{B}} & \cos \left(\beta l_{i}\right)
\end{array}\right],
$$

čia $\beta$ - fazès koeficientas.

2.10 paveiksle pateiktas linijos perdavimo koeficiento ir įejjimo varžos skaičiavimo, naudojant matricini metodą, algoritmas. Skaičiavimo pradžioje įvedami linijos parametrai (1 blokas): linijos periodo ilgis, linijos vienalyčių atkarpų ilgiai, elektromagnetinès bangos sklidimo greičiai atkarpose, atkarpu banginių ir apkrovos varžų vertès bei periodų skaičius linijoje. Skaičiuojant laikoma, kad kiekviena linijos vienalyte sritis yra atskiras keturpolis, turintis savo $\boldsymbol{A B C D}$ matricos parametrus. Toliau pradedant nuo linijos galo pakopimis jungiamos keturpolius atitinkančios vienalytes sritis, t. y. dauginamos gretimų vienalyčiu sričių $\boldsymbol{A B C D}$ matricos vienalyčių sričių sandūroje (2 blokas) ir kiekvieno periodo pradžioje (3 blokas), kol pasiekiama linijos pradžia (4-5 blokas). Tuomet gauto sudetingo ekvivalentinio keturpolio $\boldsymbol{A B C D}$ matricos parametrai prilyginami linijos $\boldsymbol{A B C D}$ matricos parametrams (6 blokas) ir apskaičiuojamas linijos perdavimo koeficientas bei įejjimo varža (7 blokas).

Sekančiame skyrelyje pateikiami turinčios periodinių netolygumų ilgosios linijos perdavimo koeficiento ir iejjimo varžos charakteristikų skaičiavimo rezultatai matricų metodu.

\subsubsection{Skaičiavimų rezultatai matricų metodu}

2.11 paveiksle (a) pateiktos perdavimo koeficiento dažninès amplitudès charakteristikos, kai linijos vienalyčių sričių banginès varžos yra lygios. 2.11 paveiksle (b) atvaizduotos perdavimo koeficiento charakteristikos, kai periodo vienalyčių sričių banginių varžų santykis bei vienalyčių sričių atkarpų ilgių santykis yra pastovūs, o periodų skaičius sistemoje kinta ir yra lygus 1, 4 ir 16. Vienalyčiu sričių banginès varžos $Z_{\mathrm{B} 1}$ ir $Z_{\mathrm{B} 2}$ yra lygios $40 \Omega$ ir $60 \Omega$. 2.11 paveiksle (c) kinta periodo vienalyčių sričių banginių varžų santykis, kuris lygus $1 ; 1,2 ; 1,3 ; 1,5$. Tiriant dažninių charakteristikų priklausomybę nuo sistemos periodo banginių varžu santykio $Z_{\mathrm{B} 1}$ kito $40-50 \Omega$ intervale, o $Z_{\mathrm{B} 2}$ kito 50-60 $\Omega$ ribose. 2.11 paveiksle (d) pateiktos perdavimo koeficiento charakteristikos, kai kinta vienalyčių sričių ilgių santykis $l_{1} / l_{2}$, kuris įgyja vertes $1 ; 2 ; 4 ; 19$. Linijos vienalyčių sričių banginès varžos ir nevienalyčių periodų skaičius šiuo atveju nekito. Linijos periodo ilgis visų tyrimų metu buvo pastovus ir lygus $0,02 \mathrm{~m}$. Elektromagnetinès bangos sklidimo greičiai linijos atkarpose lygūs šviesos greičiui, o virpesių šaltinio ir apkrovos varžos $-50 \Omega$. 


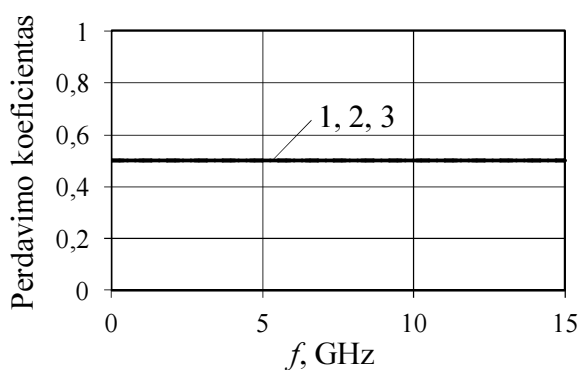

(a)

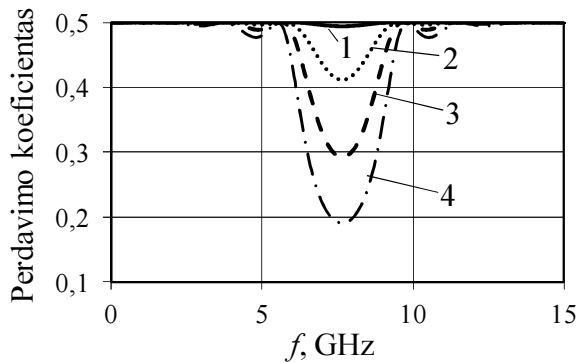

(c)

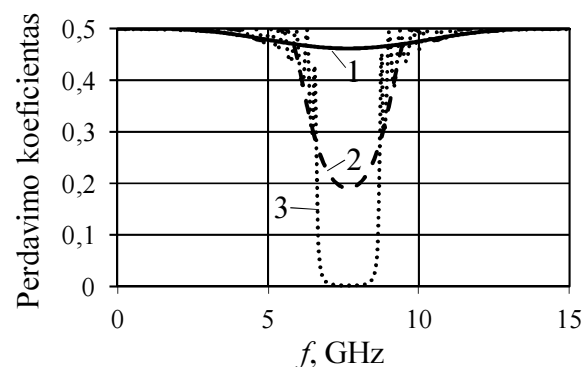

(b)

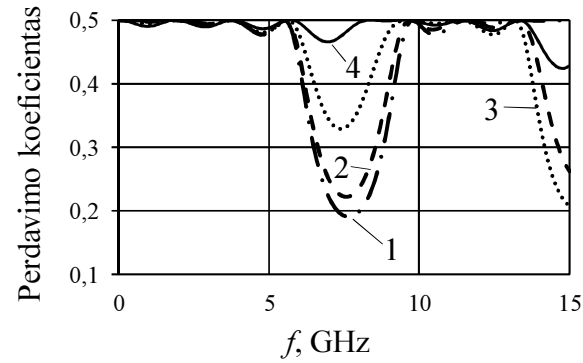

(d)

2.11 pav. Ilgosios linijos perdavimo koeficientas, kai $R_{\mathrm{a}}=R_{\mathrm{i}}=50 \Omega$ :

(a): $Z_{\mathrm{B} 1}=Z_{\mathrm{B} 2}=50 \Omega, l_{1}=l_{2}=10 \mathrm{~mm}$ ir: $1-n=1 ; 2-n=4 ; 3-n=16$;

(b): $Z_{\mathrm{B} 1}=40 \Omega, Z_{\mathrm{B} 2}=60 \Omega, l_{1}=l_{2}=10 \mathrm{~mm}$ ir: $1-n=1 ; 2-n=4 ; 3-n=16$;

(c): $n=4, l_{1} / l_{2}=1,\left(Z_{\mathrm{B} 1}+Z_{\mathrm{B} 2}\right) / 2=50 \Omega$ ir $Z_{\mathrm{B} 1} / Z_{\mathrm{B} 2}$ lygu: $1-1 ; 2-1,2 ; 3-1,3 ; 4-1,5$;

(d): $Z_{\mathrm{B} 1}=40 \Omega, Z_{\mathrm{B} 2}=60 \Omega, n=4$ ir kai $l_{1} / l_{2}$ lygu: $1-1 ; 2-2 ; 3-4 ; 4-19$

Fig. 2.11. Transfer coefficient of the transmission line at $R_{\mathrm{a}}=R_{\mathrm{i}}=50 \Omega$ and:

(a): $Z_{\mathrm{B} 1}=Z_{\mathrm{B} 2}=50 \Omega, l_{1}=l_{2}=10 \mathrm{~mm}$ and: $1-n=1 ; 2-n=4 ; 3-n=16$;

(b): $Z_{\mathrm{B} 1}=40 \Omega, Z_{\mathrm{B} 2}=60 \Omega, l_{1}=l_{2}=10 \mathrm{~mm}$ and: $1-n=1 ; 2-n=4 ; 3-n=16$;

(c): $n=4, l_{1} / l_{2}=1,\left(Z_{\mathrm{B} 1}+Z_{\mathrm{B} 2}\right) / 2=50 \Omega, Z_{\mathrm{B} 1} / Z_{\mathrm{B} 2}$ equal: $1-1 ; 2-1.2 ; 3-1.3 ; 4-1.5$;

(d): $Z_{\mathrm{B} 1}=40 \Omega, Z_{\mathrm{B} 2}=60 \Omega, n=4$ and $l_{1} / l_{2}$ equal: $1-1 ; 2-2 ; 3-4 ; 4-19$

Signalų trakto, kuriame ijungta linija su periodiniais netolygumais, dažninès amplitudinès charakteristikos vertès skaičiuotos pagal formulę:

$$
K=\left|\frac{\underline{U_{2}}}{\underline{\underline{E}}}\right| .
$$

Todèl trakto, kuriame ijungta vienalytė linija, nenormuotos dažninès amplitudès vertès yra 0,5. Dèl periodinių netolygumų atsiranda užtvarinè juosta, kurios centrinis dažnis $f_{\mathrm{c}}$ priklauso nuo linijos periodo ilgio ir išreiškiamas formule: 


$$
f_{\mathrm{c}}=\frac{v}{2 l_{\mathrm{p}}} .
$$

čia $v$ - elektromagnetinès bangos sklidimo greitis linijoje; $l_{\mathrm{p}}$ - linijos periodo ilgis.

Kaip matyti iš 2.11 paveikslų (b) ir (c), didejant periodų skaičiui arba periodo vienalyčių sričių banginių varžu santykiui, perdavimo koeficientas nuo dažnio priklauso labiau. Dèl didejjančių periodinių atspindžių plečiasi užtvarinè juosta ir didejja slopinimas užtvarinejje juostoje. Iš 2.11 paveikslo (b) matyti, kad, naudojant sistemą su vienu periodu, užtvarinès juostos nèra (neviršijama 0,707 DACh riba), o periodų skaičiui išaugus iki 16 , atsiranda $2,2 \mathrm{GHz}$ pločio užtvarine juosta. Kai linijos vienalyčių sričiu banginių varžų santykis lygus 1 , užtvarinès juostos nèra, o kai vienalyčių sričių banginių varžu santykis išauga iki 1,5, atsirado $2,7 \mathrm{GHz}$ pločio užtvariné juosta (2.11 pav. c). Iš 2.11 paveikslo (d) matyti, kad užtvarinè juosta plačiausia ir slopinimas joje didžiausias, kai vienalyčių atkarpų ilgių santykis periode artèja prie vieneto. Beje, dèl periodinių netolygumų atsiranda ne vienintelè užtvarinè juosta. Kai $l_{1} \neq l_{2}$, užtvarinès juostos gaunamos ir ties kartotiniais dažniais $m f_{\mathrm{c}}$ (kai periode telpa sveikasis pusbangių skaičius $m$ ). Kai linijos vienalyčių sričių ilgių santykis lygus vienetui, turime 2,7 $\mathrm{GHz}$ pločio užtvarinę juostą. Vienalyčių sričių ilgių santykiui didejjant, užtvarinė juosta siaurejja bei slopinimas joje mažeja.

Žinant $\boldsymbol{A B C D}$ matricos koeficientus galima apskaičiuoti ir linijos iejjimo varžą. Kadangi iejjimo varža lygi iẹjimo ịtampos ir srovès santykiui, remdamiesi banginiu keturpoliu (2.8 pav.) ir naudodami (2.5) lygčių sistemą galime gauti iejjimo varžos išraišką:

$$
\underline{Z}_{\mathrm{IN}}=\frac{\underline{U}_{1}}{\underline{I}_{1}}=\frac{\underline{A} \cdot \underline{U}_{2}-\underline{B} \cdot \underline{I}_{2}}{\underline{C} \cdot \underline{U}_{2}-\underline{D} \cdot \underline{I}_{2}}=\frac{\underline{A} \cdot \underline{Z}_{\mathrm{a}}+\underline{B}}{\underline{C} \cdot \underline{Z}_{\mathrm{a}}+\underline{D}},
$$

čia $\underline{U}_{1}$ - linijos iejjimo įtampa; $\underline{I}_{1}-$ linijos ièjimo srove; $\underline{U}_{2}-$ linijos išèjimo įtampa; $\underline{I}_{2}$ - linijos išejimo srove; $\underline{Z}_{\mathrm{a}}-\operatorname{linijos}$ apkrovos varža; $\underline{A}, \underline{B}, \underline{C}, \underline{D},-\boldsymbol{A B C D}$ matricos koeficientai.

Skaičiavimo rezultatai pateikti $2.12-2.14$ paveiksluose. 2.12 paveiksle pateiktos iejjimo varžos dažninès charakteristikos, kai kito periodų skaičius 1,2 ir 4 , o vienalyčių sričių banginès varžos $Z_{\mathrm{B} 1}$ ir $Z_{\mathrm{B} 2}$ buvo pastovios ir lygios $40 \Omega$ ir $60 \Omega$. Vienalyčių sričių ilgių santykis $l_{1} / l_{2}$ buvo pastovus ir lygus vienetui. Rezultatai analogiški gautiesiems ilgujuc linijų metodu ankstesniame poskyryje. Bendruoju atveju linijos iejjimo varža yra kompleksinè. Jos realioji, menamoji dalys ir modulis priklauso nuo dažnio. Modulis tampa maksimalus, kai elektromagnetinès bangos ilgis tampa dvigubai didesnis nei linijos periodo ilgis. Iš gautų rezultatų matyti, kad, didejjant periodų skaičiui, $\underline{Z}_{\text {IN }}$ kinta labiau: kai elektro- 
magnetinès bangos ilgis tampa dvigubai didesnis nei linijos periodo ilgis, įejjimo varžos modulis didinant periodų skaičių didejja. Padidinus periodų skaičių nuo 1 iki 4 įejjimo varžos modulio maksimumai išaugo 3 kartus nuo $112 \Omega$ iki $340 \Omega$.

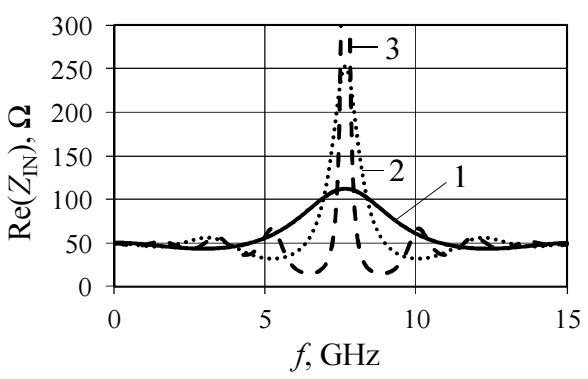

(a)

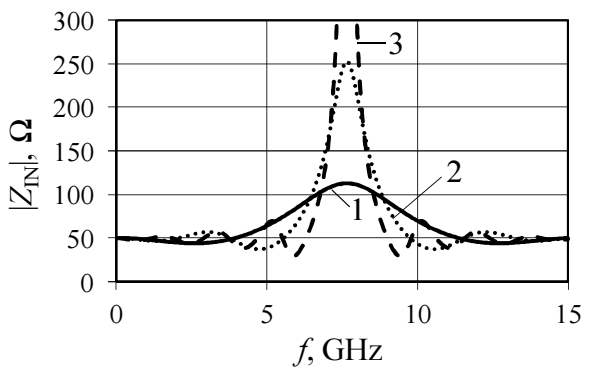

(c)

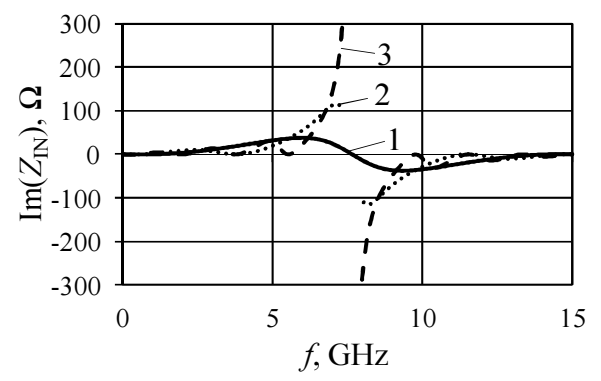

(b)

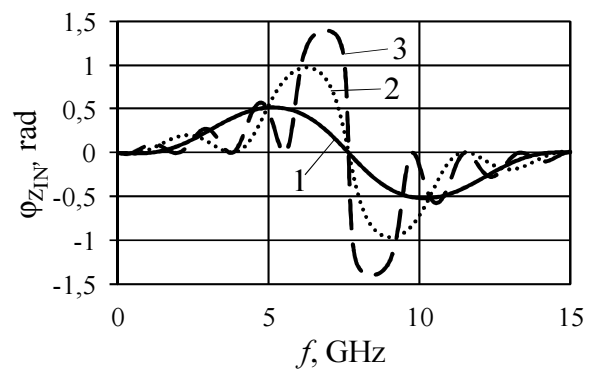

(d)

2.12 pav. Ilgosios linijos ịejimo varžos realiosios (a), menamosios (b) dedamujų, modulio (c) ir fazės (d) dažninès charakteristikos, kai $Z_{\mathrm{B} 1}=40 \Omega, Z_{\mathrm{B} 2}=60 \Omega$,

$$
l_{1}=l_{2}=10 \mathrm{~mm} \text { ir kai: } 1-n=1 ; 2-n=2 ; 3-n=4 \text { periodai }
$$

Fig. 2.12. Active (a), reactive (b), module (c) and argument (d) of input impedance versus frequency of the transmission line at $Z_{\mathrm{B} 1}=40 \Omega, Z_{\mathrm{B} 2}=60 \Omega, l_{1}=l_{2}=10 \mathrm{~mm}$ and: $1-n=1 ; 2-n=2 ; 3-n=4$ periods

2.13 paveiksle pateiktos iejjimo varžos $\underline{Z}_{\text {IN }}$ dažninès charakteristikos, kai kinta vienalyčių sričių banginių varžų santykis, kuris lygus $1 ; 1,2 ; 1,5$. Tiriant dažninių charakteristikų priklausomybę nuo sistemos periodo banginių varžų santykio banginè varža $Z_{\mathrm{B} 1}$ kito $40-50 \Omega$, o $Z_{\mathrm{B} 2}$ kito $50-60 \Omega$ ribose. Sistema buvo sudaryta iš 4 periodų, o vienalyčiu sričių $l_{1}$ ir $l_{2}$ ilgių santykis nekito ir buvo lygus vienetui.

Iš gautų rezultatų matyti, kad linijos ięjimo varža yra kompleksinè. Modulis tampa ekstremalus, kai elektromagnetinès bangos ilgis yra dvigubai didesnis nei linijos periodo ilgis $l_{\mathrm{p}}$, t. y., kai tenkinama sąlyga $l_{\mathrm{p}}=\lambda / 2$. Tada ties dažniu $f=v / 2 l_{\text {p }}$ iejjimo varža yra grynai aktyvioji. Be to didejjant vienalyčių sričių ban- 
ginių varžų santykiui užtvarinès savybès ryškèja, t. y. iejjimo varžos modulio ekstremumų vertès didejja. Didinant linijos vienalyčių sričių banginių varžų santykị nuo 1 iki 1,5 ịejjimo varžos modulio ekstremumai išaugo beveik 7 kartus nuo $55 \Omega$ iki $385 \Omega$.

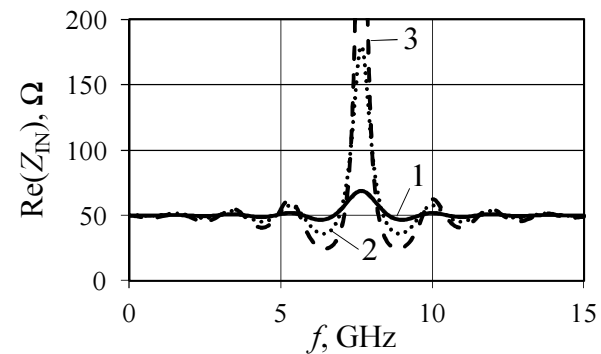

(a)

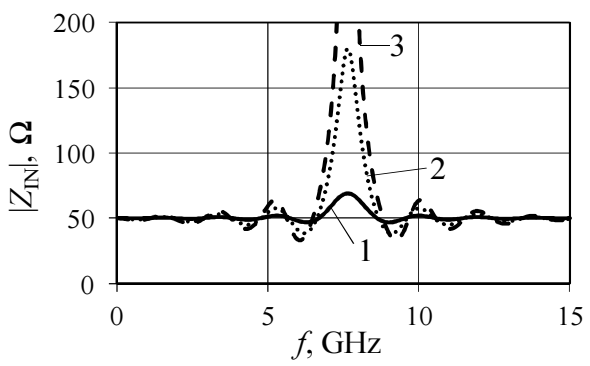

(c)

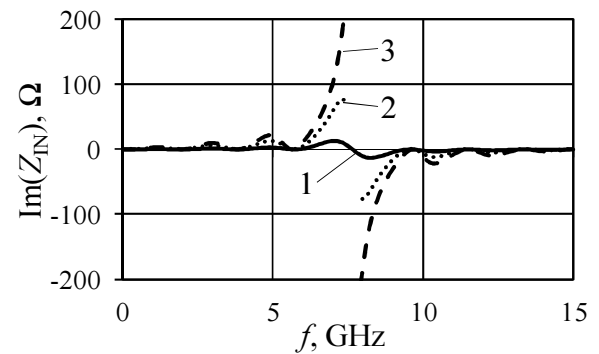

(b)

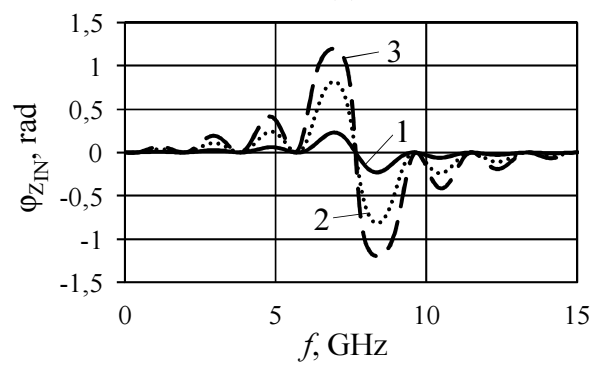

(d)

2.13 pav. Ilgosios linijos ięjimo varžos realiosios (a), menamosios (b) dedamujų, modulio (c) ir fazės (d) dažninès charakteristikos, kai $l_{1}=l_{2}=10 \mathrm{~mm}, n=4$,

$$
\left(Z_{\mathrm{B} 1}+Z_{\mathrm{B} 2}\right) / 2=50 \Omega \text { ir } Z_{\mathrm{B} 1} / Z_{\mathrm{B} 2} \text { lygu: } 1-1 ; 2-1,2 ; 3-1,5
$$

Fig. 2.13. Active (a), reactive (b), module (c) and argument (d) of input impedance versus frequency of the transmission line at $l_{1}=l_{2}, n=4,\left(Z_{\mathrm{B} 1}+Z_{\mathrm{B} 2}\right) / 2=50 \Omega$ and

$$
Z_{\mathrm{B} 1} / Z_{\mathrm{B} 2} \text { equal to: } 1-1 ; 2-1.2 ; 3-1.5
$$

2.14 paveiksle pateiktos iejjimo varžos charakteristikos, kai kinta nevienalyčių sričių ilgių santykis, kuris igauna reikšmes $1 ; 4 ; 19$. Periodų skaičius yra pastovus ir lygus 4 , o vienalyčių sričių banginès varžos nekinta ir yra lygios $Z_{\mathrm{B} 1}=40 \Omega$ ir $Z_{\mathrm{B} 2}=60 \Omega$. Dar buvo priimta, kad elektromagnetinès bangos sklidimo greičiai linijos atkarpose lygūs šviesos greičiui, o virpesių šaltinio ir apkrovos varžos $-50 \Omega$.

Iš 2.14 paveikslo matyti, $\mathrm{kad} \underline{Z}_{\mathrm{IN}}$ modulis tampa maksimalus, kai elektromagnetinès bangos ilgis yra dvigubai didesnis nei linijos periodo ilgis. $\underline{Z}_{\mathrm{IN}}$ modulio maksimumai didejja, kai vienalyčių atkarpų ilgių santykis artèja prie vieneto. Beje, kai $l_{1}=l_{2}$, dèl periodinių netolygumų $\underline{Z}_{\mathrm{IN}}$ modulio maksimumai 
atsiranda ir ties kartotiniais $m f_{\mathrm{c}}$ dažniais (kai periode telpa sveikasis pusbangiu skaičius $m$ ). Mažèjant linijos vienalyčių sričiu ilgių santykiui nuo 19 iki 1, iejjimo varžos modulio maksimumas ties centriniu dažniu išauga 8 kartus nuo $47 \Omega$ iki $391 \Omega$.

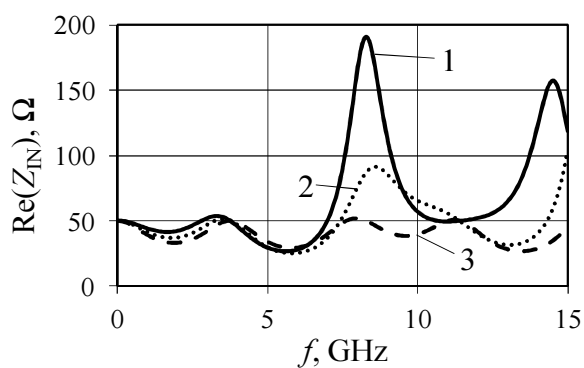

(a)

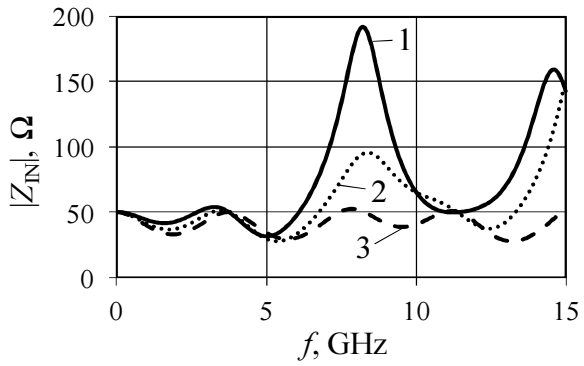

(c)

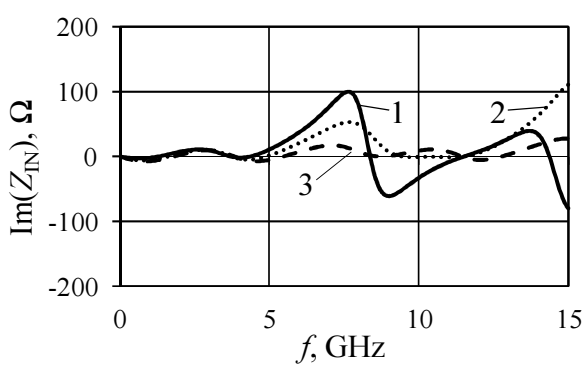

(b)

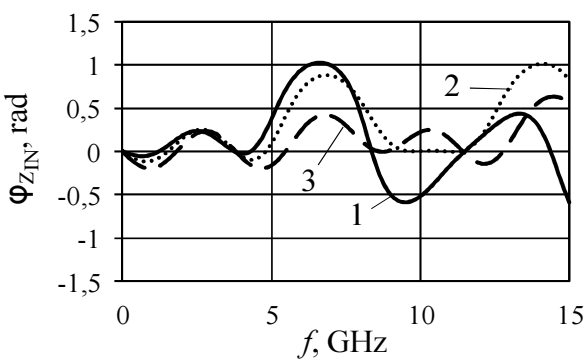

(d)

2.14 pav. Ilgosios linijos ięjimo varžos realiosios (a), menamosios (b) dedamujų, modulio (c) ir fazès (d) dažninès charakteristikos, kai $Z_{\mathrm{B} 1}=40 \Omega, Z_{\mathrm{B} 2}=60 \Omega, n=4$ ir:

$$
1-l_{1} / l_{2}=1 ; 2-l_{1} / l_{2}=4 ; 3-l_{1} / l_{2}=19
$$

Fig. 2.14. Active (a), reactive (b), module (c) and argument (d) of imput impedance versus frequency of the transmission line at $Z_{\mathrm{B} 1}=40 \Omega, Z_{\mathrm{B} 2}=60 \Omega, n=4$ and:

$$
1-l_{1} / l_{2}=1 ; 2-l_{1} / l_{2}=4 ; 3-l_{1} / l_{2}=19
$$

Taigi, taikant banginių matricų metodą galima apskaičiuoti ilgosios linijos perdavimo koeficiento ir įjimo varžos charakteristikas. Atspindžių nuo vienalyčių sričių sukelti rezonansiniai reiškiniai lemia užtvarinès juostos atsiradimą. Didejjant periodiniam nevienalytiškumui užtvarinè juosta platèja. Periodiniai netolygumai imituoti, keičiant linijos nevienalyčiu periodų skaičių, vienalyčių sričių banginių varžų ir vienalyčių sričių ilgių santykius. Iš perdavimo koeficiento charakteristikos matyti, kad ilgojoje linijoje pradeda formuotis užtvarine juosta, kai vienalyčių sričių banginių varžų santykis išauga iki 1,3 ir vienalyčių sričių ilgių santykis sumažejja iki 2 arba kai linijoje yra daugiau nei vienas nevienalytis 
periodas. Taikant banginių matricų metodą apskaičiuotos iejjimo varžų charakteristikos sutampa su gautomis, taikant ilgụjų linijų metodą.

\subsection{Periodinių netolygumų įtaka pereinamajai charakteristikai}

Dèl keturpolio dažninès amplitudès charakteristikos netolygumo ir dažninės fazès charakteristikos netiesiškumo gaunami signalų formos iškraipymai. Apie galimus impulsinių signalų iškraipymus galima spręsti iš keturpolio impulsinès arba pereinamosios charakteristikų.

Śiame poskyriuje nagrinèsime, užtvarinès juostos pločio įtaką pereinamajai charakteristikai ir impulsinių signalų iškraipymams.

\subsubsection{Pereinamosios charakteristikos ir impulsinių signalų formos tyrimai}

Impulsine charakteristika vadinama sistemos reakcija i $\delta(t)$ impulso poveikị. Pereinamaja charakteristika vadinama sistemos reakciją $i$ vienetinio šuolio formos iejjimo signalą. Remiantis pereinamaja charakteristika randami parametrai: impulso fronto trukmè $\tau_{f}$ ir vèlinimo trukmè $t_{\mathrm{v}}(2.15$ pav.). Fronto trukmè matuojama tarp pereinamosios charakteristikos lygių 0,1 ir 0,9 , vèlinimo laikas tarp 0 ir 0,1 lygių.

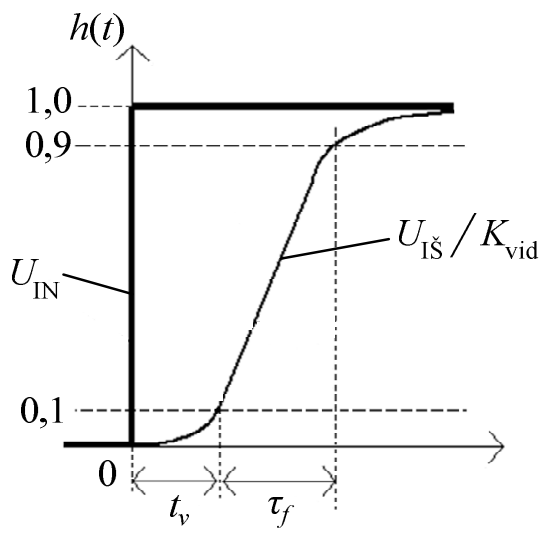

2.15 pav. Pereinamoji charakteristika

Fig. 2.15. Transient response 
Modeliuojant lètinimo sistemas svarbu atsižvelgti ị signalų iškraipymą lemiančias priežastis, todèl aptariama pereinamujų charakteristikų iškraipymą lemiantys faktoriai. Darbe (Štaras et al. 2012) išsamiai išnagrinètos bègančiosios bangos elektroninių vamzdžių dinaminių charakteristikų priklausomybės nuo slopinimo, dispersijos kreipimo sistemoje, elektronų lèkio trukmès ir kitų veiksnių. Suformuluoti reikalavimai kreipimo sistemų parametrams, kuriuos įvykdžius galima gauti reikalaujamą vamzdžio ekvivalentinès pralaidumo juostos plotị ir pereinamosios charakteristikos fronto trukmę.

Vienas iš svarbiausių veiksnių, lemiančiu bėgančiosios bangos elektroninio vamzdžio praleidžiamuju dažnių juostos plotị yra dispersija, kuri nustatoma iš sistemos vèlinimo trukmès dažninès charakteristikos $t_{\mathrm{v}}(f)$. Dél elektromagnetinès bangos ir elektronų greičių nesuderinamumo gaunami dažniniai amplitudiniai iškraipymai (Štaras et al. 2010).

Didejant dažniui, didejja fazių skirtumas $\theta$ tarp spiralinès ar meandrinès sistemos gretimų laidininku ir to pasekoje kinta ilginè talpa bei sistemos banginé varža. Tuomet nuo sistemos periodinių netolygumų susidaro atspindžiai, dèl kurių atsiranda pereinamosios charakteristikos svyravimai. Svyravimus taip pat lemia ir atspindžiai nuo sistemos iejjimų ir išejjimų.

Literatūroje išnagrinèta daugelio faktorių ịtaka pereinamajai charakteristikai ir signalų formos iškraipymams, tačiau mažai dèmesio skirta užtvarinès juostos itakai. Todèl ištirsime užtvarinès juostos pločio įtaką pereinamajai charakteristikai ir signalų formos iškraipymams.

Pereinamoji charakteristika skaičiuojama taikant formulę:

$$
T(t)=\frac{K(0)}{2}+\frac{1}{\pi} \int_{0}^{\infty} \frac{K(\omega)}{\omega} \sin (\omega t+\varphi(\omega)) d \omega,
$$

čia $K(\omega)$ - dažninė amplitudès charakteristika; $\varphi(\omega)$ - dažninè fazès charakteristika.

Siekiant išvengti pereinamujų charakteristikų osciliacijų dèl viršutinio integravimo rèžio, ị pointegralinị reiškinị ịrašomas Bernšteino ir Rogozinskio daugiklis. Tuomet (2.15) formule iggauna pavidalą:

$$
T_{0}(t)=\frac{1}{2}+\frac{1}{\pi} \int_{0}^{\omega_{\mathrm{B}}}\left(\cos \left(\frac{\pi \omega}{2 \omega_{\mathrm{B}}}\right)\right)^{2} \frac{K_{0}(\omega)}{\omega} \cos \left(\omega t+\phi_{0}(\omega)-\frac{\pi}{2}\right) d \omega,
$$

čia $\omega_{\mathrm{B}}=2 \pi f_{\mathrm{B}}$, kur $f_{\mathrm{B}}$ žymi srities aukščiausią dažnį, iki kurio integruojame.

Taikydami (2.16) formulę ištirsime, kaip kinta pereinamoji charakteristika priklausomai nuo užtvarinès juostos pločio, kai naudojamas status ir baigtinio statumo fronto impulsas. 


\subsubsection{Pereinamosios charakteristikos ir impulsinių signalụ skaičiavimo rezultatai}

2.16 paveiksle (a) pateiktos perdavimo charakteristikos su skirtingu užtvarinès juostos pločiu. Siekiant pateikti vaizdžius rezultatus, naudojome perdavimo charakteristikas, kai užtvarinès juostos nèra ir kai užtvarinès juostos plotis lygūs 5, 20 ir $30 \%$ centrinio užtvarinès juostos dažnio. Pereinamosios charakteristikos plokščiosios srities netolygumai gali atsirasti dèl baigtinio viršutinio integravimo rèžio ir užtvarinès juostos. Noredami tirti pereinamosios charakteristikos plokščiosios srities netolygumus, atsirandančius dèl užtvarinès juostos, pašalinome baigtinio viršutinio integravimo rèžio sukeliamus netolygumus, atsirandančius naudojant apribotą signalo spektro dalį. Viršutinio integravimo rèžio sukeliami netolygumai pašalinami panaudojus Beršteino ir Rogožinskio daugiklį.

2.16 paveiksle (a) pateiktos perdavimo charakteristikos, kai užtvarinès juostos plotis lygus $0,5,20$ ir 30 procentu centrinio užtvarinès juostos dažnio.

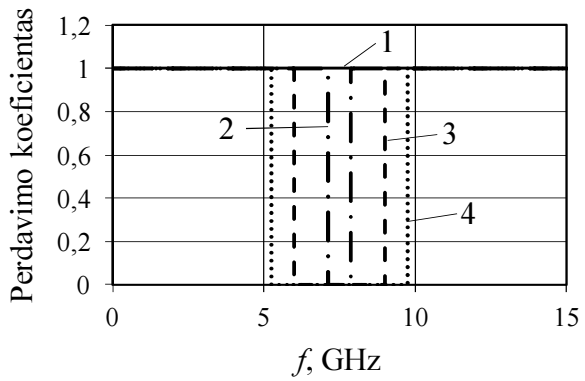

(a)

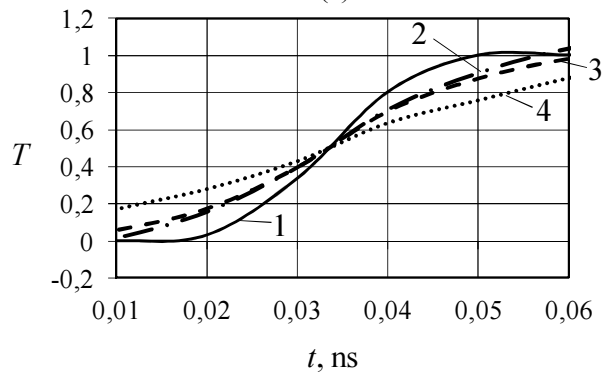

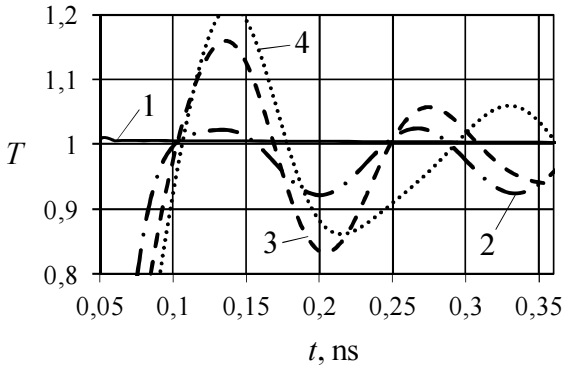

(b)

(c)

2.16 pav. Dažninè amplitudès charakteristika su skirtingo pločio užtvarine juosta (a), pereinamosios charakteristikos plokščiosios srities (b) ir užaugimo fronto (c) priklausomybès nuo užtvarinès juostos pločio, kai užtvarinės juostos plotis lygus $1-0 \% ; 2-5 \% ; 3-20 \% ; 4-30 \%$ centrinio užtvarinès juostos dažnio

Fig. 2.16. Amplitude-frequency responses (a), the flat area (b) and the growing area (c) of transient responses then stop-band is equal to: $1-0 \% ; 2-5 \% ; 3-20 \% ; 4-30 \%$ of central frequency of the stop-band 
2.16 paveiksluose (b) ir (c) pateiktos pereinamosios charakteristikos plokščiosios ir fronto sritys, atitinkančios 2.16 paveiksle (a) pateiktas perdavimo charakteristikas, su skirtingu užtvarinès juostos pločiu. Iš 2.16 paveikslo matyti, kad didejjant užtvarinès juostos pločiui, pereinamosios charakteristikos plokščiosios srities netolygumai didejja. Užtvarinès juostos pločiui padidèjus nuo 5 iki $30 \%$ centrinio užtvarinès juostos dažnio (2.16 pav. a), pereinamosios charakteristikos plokščiosios srities netolygumai padidejja 3 kartus (2.16 pav. b). Toks didelis skirtumas gaunamas tik plokščiosios srities pradžioje - laiko srityje nuo 0,1 iki 0,15 ns. Toliau nuo fronto pereinamosios charakteristikos plokščiosios srities netolygumai sumažejja iki 2 kartų.

Iš 2.16 paveikslo (c) matyti, kad didejjant užtvarinès juostos pločiui pereinamosios charakteristikos frontas darosi nuožulnesnis, t. y. fronto kilimo trukmé ilgèja. Mūsų atveju užtvarinès juostos pločiui padidèjus nuo 5 iki $30 \%$ centrinio užtvarinès juostos dažnio fronto trukmè padidèjo nuo 34 ps iki 59 ps, t. y. $73 \%$.

Praktikoje impulsų frontai nèra be galo statūs ir jų dažninių spektrų plotis yra ribotas. İtampų šuolių su baigtinio statumo frontu arba kitų faktorių įtaką (pvz., realių ịtaisų ribotas dažnines savybes) galima modeliuoti i pointegralinị reiškini ịvedant papildomus daugiklius. Šiuo atveju noredami modeliuoti kitų faktorių itaką naudojome $\sin (k f) / k f$ pavidalo daugikli, kur $k$ - konstanta. 2.17 paveiksle pateiktos dažninès amplitudès charakteristikos ir jas atitinkančios pereinamosios charakteristikos atvejais, kai vertinama tik užtvarinès juostos įtaka ir kai veikia kiti faktoriai, ribojantys praleidžiamųjų dažnių juostos plotį.

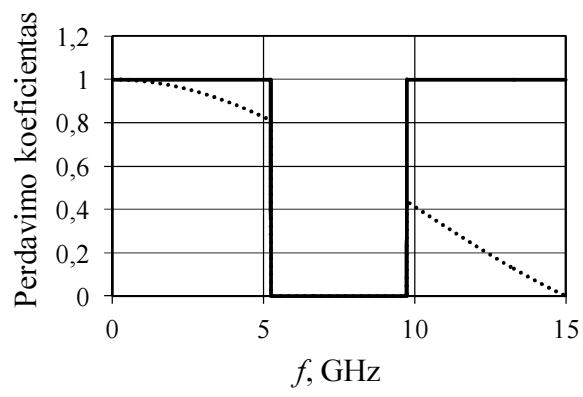

(a)

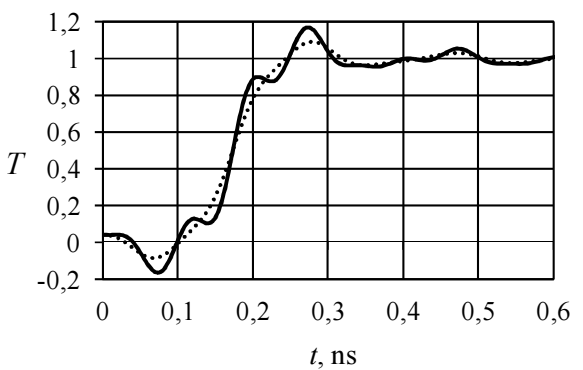

(b)

2.17 pav. Dažninès amplitudès charakteristikos (a) ir pereinamosios charakteristikos (b), kai užtvarinès juostos plotis lygus $30 \%$ centrinio užtvarinès juostos dažnio

Fig. 2.17. Amplitude-frequency responses (a) and transient responses (b) then stop-band is equal to $30 \%$ of central frequency of the stop-band

Iš 2.17 paveikslo (b) matyti, kad, didèjant ịtampos šuolio fronto trukmei, t. y. mažejjant realių impulsų spektro pločiui, iškraipymai dèl užtvarinès juostos mažèja. 


\subsection{Sistemų tyrimas taikant specializuotą programinę ịrangą}

Pastaruoju metu ịvairiems įtaisams modeliuoti vis dažniau taikomi skaitiniai metodai ir specializuotos programų sistemos (Metlevskis, Martavičius 2012). Šiame poskyryje nevienalytès periodinès sistemos tiriamos, taikant programų paketą CST Microwave Studio ${ }^{\circledR}$, taikant baigtinių skirtumų laiko srities metodą. Ilgujjų linijų ir matriciniu metodais gauti rezultatai lyginami su CST Microwave Studio ${ }^{\circledR}$ programų paketu gautais rezultatais.

\subsubsection{Nevienalyčių periodinių sistemų tyrimo modeliai}

Ilgoji linija su periodiniais netolygumais specializuoto programu paketo CST Microwave Studio ${ }^{\circledR}$ terpeje modeliuojama bendraašio kabelio atkarpomis. Periodiniai netolygumai ịvertinami, keičiant centrinio laidininko skersinius matmenis, dielektriko skersinius matmenis, nevienalyčių periodų skaičių bei vienalyčių sričių ilgius.

Taikant 2.18 paveiksle pateiktą schemą galima tiesiogiai apskaičiuoti ilgosios linijos su periodiniais netolygumais dažnines amplitudès (DACh) ir fazès (DFCh) charakteristikas. Skaičiuojant priimta, kad signalo šaltinio $\underline{E}$ vidaus varža $R_{\mathrm{i}}$ ir apkrovos varža $R_{\mathrm{a}}$ yra lygios tiriamosios spiralinès sistemos banginei varžai $Z_{\mathrm{B}}$ žemųjų dažnių srityje. Ieškant ịejjimo varžos reikšmių sistemos iejjimo varžą galima rasti keičiant signalo šaltinio ir generatoriaus varžas tol, kol gaunami mažiausi atspindžiai.

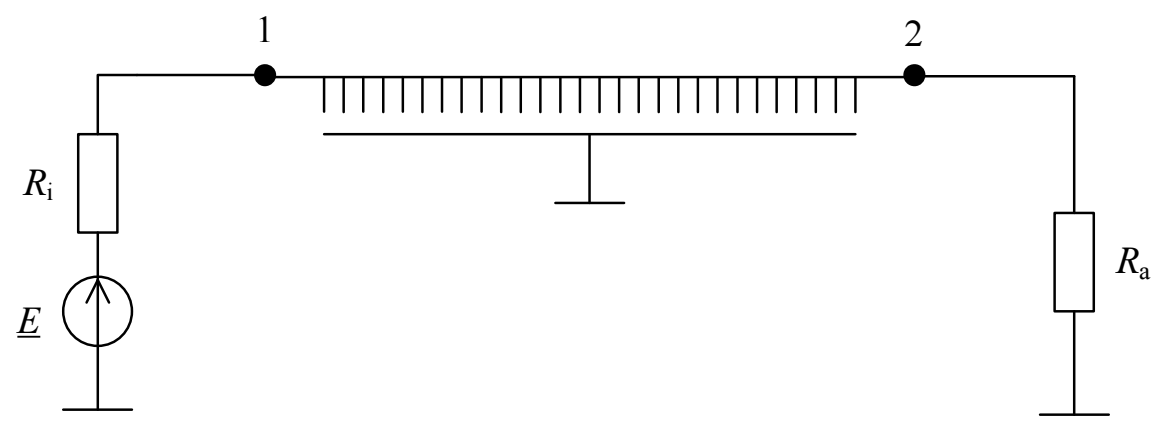

2.18 pav. Ilgosios linijos, ijungtos ị signalo kanalą ir turinčios periodinių netolygumų, principinè elektrinè schema

Fig. 2.18. The principal electric scheme of a transmission line with periodic inhomogeneities, pluged into transmission channel 
2.19 paveiksle pateiktas bendraašio kabelio modelis CST Microwave Studio $^{\circledR}$ terpèje, sudarytas iš keturių nevienalyčių periodų. Vienalytės sritys šiuo atveju sudarytos keičiant vidinio laidininko skersinius matmenis. Storejant vidiniam laidininkui kartu plonejja dielektriko sluoksnio storis, taigi mažèja banginè varža.

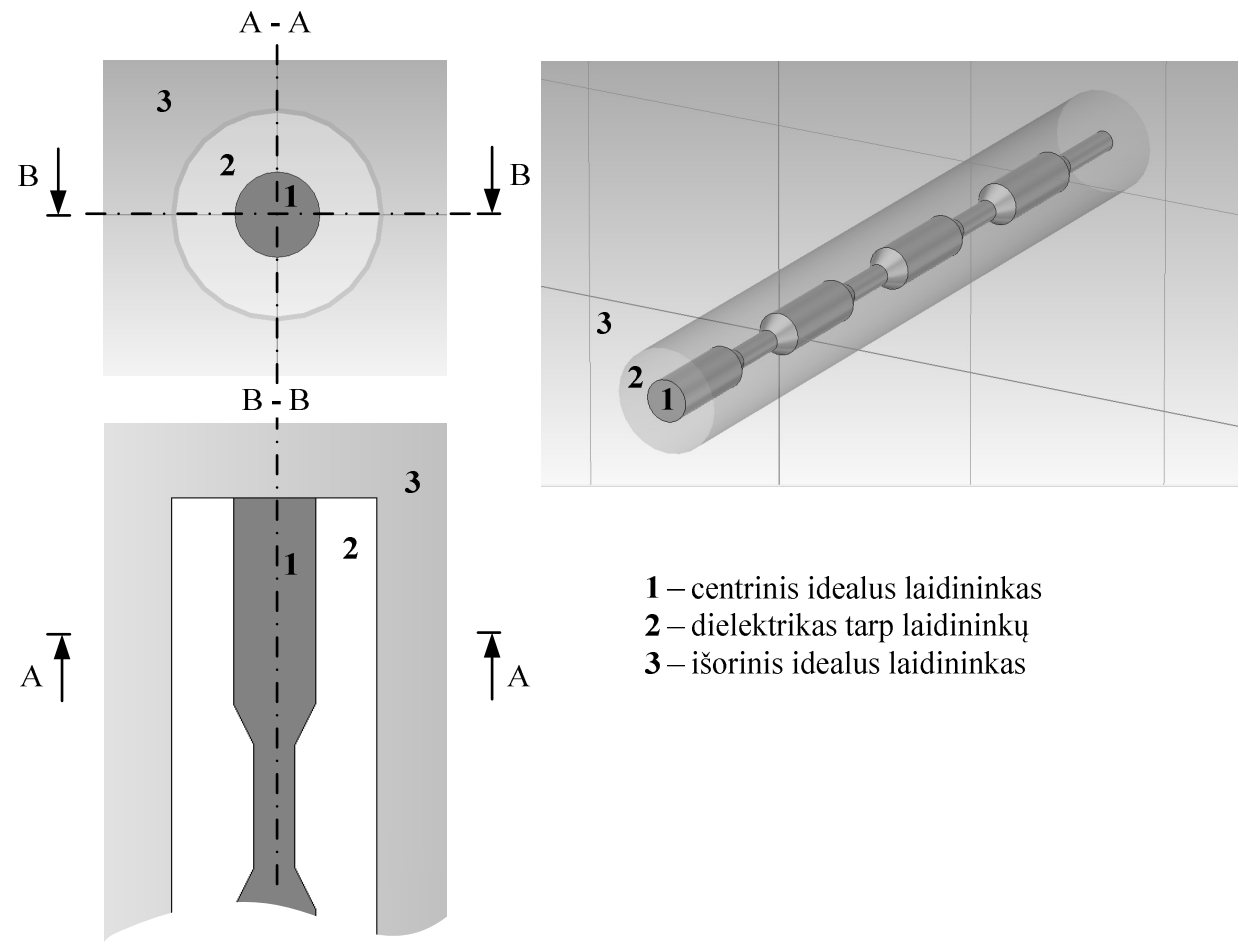

2.19 pav. Bendraašio kabelio fregmentas ir jo skersiniai pjūviai

Fig. 2.19. The fragment of coaxial cable and its cross-sections

Vidinis laidininkas yra idealus laidininkas. Ji gaubia vakuumo sluoksnis, kurio $\varepsilon_{\mathrm{r}}=1$ ir $\mu_{\mathrm{r}}=1$. Išorinis idealus laidininkas nustatomas kaip terpe aplink dielektriko sluoksni.

Periodiniai netolygumai įvertinami keičiant bendraašio kabelio nevienalyčių periodų skaičių nuo vienalytės linijos iki 16 periodų. Periodiniai nevienalytiškumai sudaromi keičiant laidininko ir dielektriko skersinius matmenis ir keičiant vienalyčių sričių ilgius.

Tyrimams taikomas CST Microwave Studio ${ }^{\circledR}$ Transient Solver paketas, dirbantis baigtinių skirtumų laiko srities metodu. 


\subsubsection{Nevienalyčiụ periodinių sistemų modeliavimo rezultatai}

2.20 paveiksle pateiktos dažninès amplitudès charakteristikos, gautos CST Microwave Studio ${ }^{\circledR}$ programu paketu, taikant baigtiniu skirtumų laiko srities metodą. 2.20 paveiksle (a) pateiktos charakteristikos, kai periodo vienalyčiu sričių banginių varžų $Z_{\mathrm{B} 1}$ ir $Z_{\mathrm{B} 2}$ santykis bei vienalyčių sričių atkarpų ilgių $l_{1}$ ir $l_{2}$ santykis yra pastovūs, o periodų skaičius sistemoje kinta ir yra lygus 1, 4 ir 16 . 2.20 paveikslo (b) charakteristikos apibūdina sistemą, kai kinta periodo vienalyčiu sričių banginių varžu santykis $Z_{\mathrm{B} 1} / Z_{\mathrm{B} 2}$, kuris lygus $1 ; 1,25 ; 1,5$. Vienalyčių sričių banginès varžos kitimas ịvertinamas, keičiant centrinio laidininko storị.

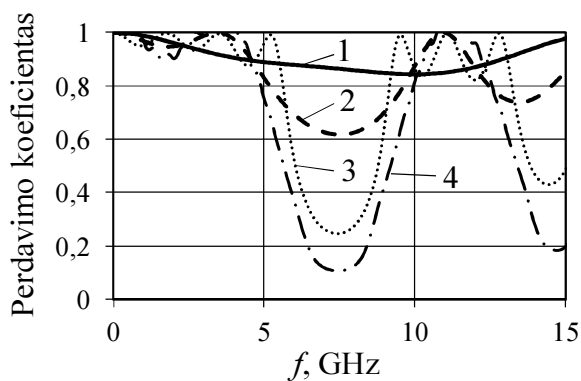

(a)

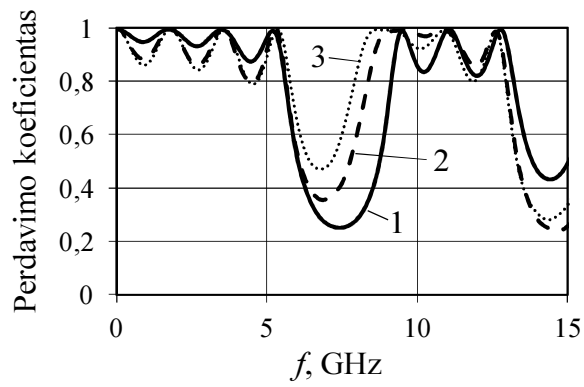

(c)

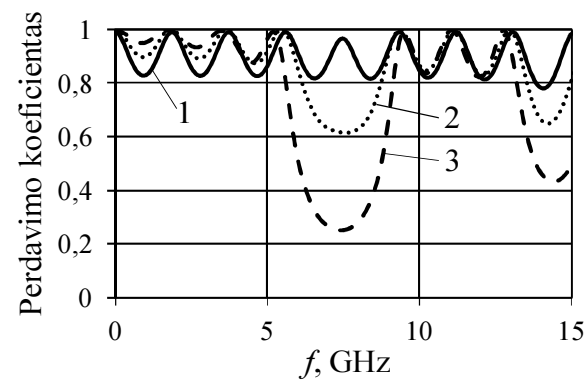

(b)

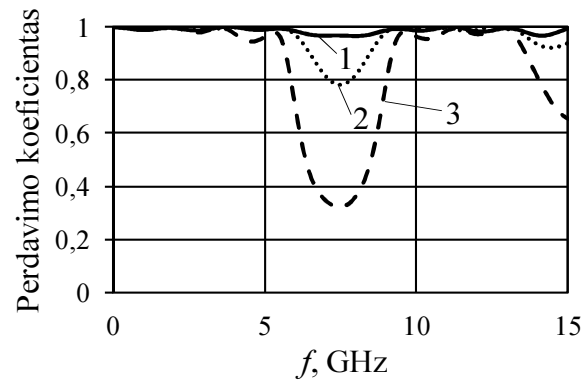

(d)

2.20 pav. Bendraašio kabelio perdavimo koeficientas, kai $R_{\mathrm{a}}=R_{\mathrm{i}}=50 \Omega$ ir:

(a): $l_{1} / l_{2}=1, Z_{\mathrm{B} 1} / Z_{\mathrm{B} 2}=1,5$ ir: $1-n=1 ; 2-n=4 ; 3-n=4 ; 4-n=16$;

(b): $l_{1} / l_{2}=1, n=4$, ir: $1-Z_{\mathrm{B} 1} / Z_{\mathrm{B} 2}=1 ; 2-Z_{\mathrm{B} 1} / Z_{\mathrm{B} 2}=1,25 ; 3-Z_{\mathrm{B} 1} / Z_{\mathrm{B} 2}=1,5$;

(c): $n=4, Z_{\mathrm{B} 1} / Z_{\mathrm{B} 2}=1,5$ ir: $1-l_{1} / l_{2}=1 ; 2-l_{1} / l_{2}=1,5 ; 3-l_{1} / l_{2}=2$;

(d): $l_{1} / l_{2}=1, n=4$ ir: $1-Z_{\mathrm{B} 1} / Z_{\mathrm{B} 2}=0,5 ; 2-Z_{\mathrm{B} 1} / Z_{\mathrm{B} 2}=1 ; 3-Z_{\mathrm{B} 1} / Z_{\mathrm{B} 2}=2$

Fig. 2.20. Transfer coefficient of the coaxial cable at $R_{\mathrm{a}}=R_{\mathrm{i}}=50 \Omega$ and:

(a): $l_{1} / l_{2}=1, Z_{\mathrm{B} 1} / Z_{\mathrm{B} 2}=1.5$ and: $1-n=1 ; 2-n=4 ; 3-n=4 ; 4-n=16$;

(b): $l_{1} / l_{2}=1, n=4$, and: $1-Z_{\mathrm{B} 1} / Z_{\mathrm{B} 2}=1 ; 2-Z_{\mathrm{B} 1} / Z_{\mathrm{B} 2}=1.25 ; 3-Z_{\mathrm{B} 1} / Z_{\mathrm{B} 2}=1.5$;

(c): $n=4, Z_{\mathrm{B} 1} / Z_{\mathrm{B} 2}=1.5$ and: $1-l_{1} / l_{2}=1 ; 2-l_{1} / l_{2}=1.5 ; 3-l_{1} / l_{2}=2$;

(d): $l_{1} / l_{2}=1, n=4$ and: $1-Z_{\mathrm{B} 1} / Z_{\mathrm{B} 2}=0.5 ; 2-Z_{\mathrm{B} 1} / Z_{\mathrm{B} 2}=1 ; 3-Z_{\mathrm{B} 1} / Z_{\mathrm{B} 2}=2$ 
2.20 paveiksle (c) pateiktos dažninès amplitudès charakteristikos, kai kinta vienalyčių sričių ilgių santykis, kuris ịgyja vertes $1 ; 1,5 ; 2.2 .20$ paveiksle (d) pateikiamos dažninès amplitudès charakteristikos, kai banginių varžų kitimą lemia dielektriko storio kitimas.

Iš 2.20 paveikslų (a), (b) ir (d) matyti, kad didejjant periodų skaičiui arba periodo vienalyčių sričių banginių varžų santykiui, kuris pasiekiamas keičiant centrinio laidininko arba dielektriko storio matmenis, dažninè amplitudès charakteristika nuo dažnio priklauso labiau. Dèl didejjančių periodinių atspindžių plečiasi užtvarine juosta ir didèja slopinimas užtvarinejje juostoje. Naudojant sistemą su vienu periodu, užtvarinès juostos nèra, o periodų skaičiui išaugus iki 16, atsiranda $4,5 \mathrm{GHz}$ pločio užtvariné juosta (2.20 pav. a). Užtvarinė juosta plačiausia ir slopinimas joje didžiausias, kai vienalyčių atkarpų ilgių santykis periode artëja prie vieneto (2.20 pav. c).

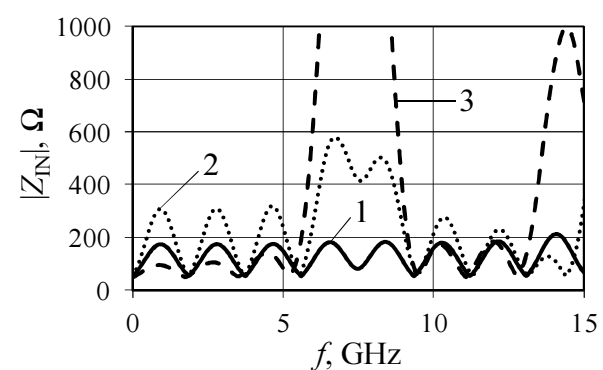

(a)

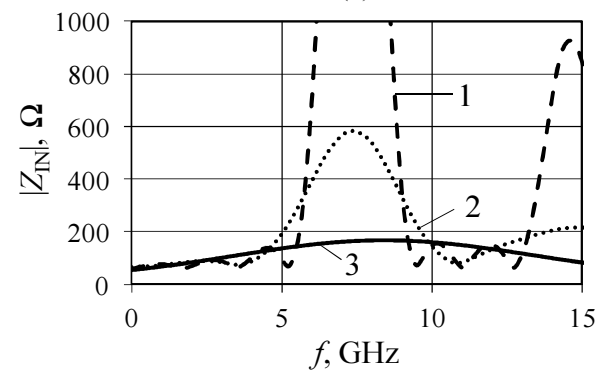

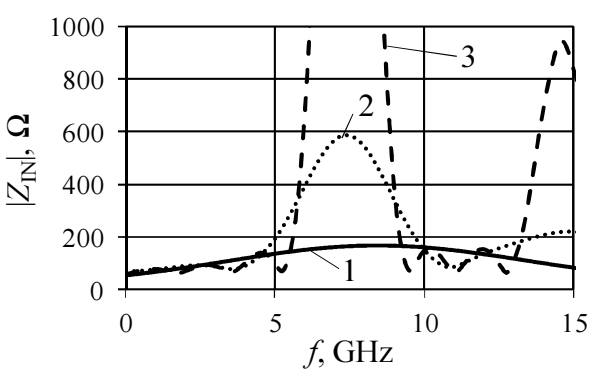

(b)

(c)

2.21 pav. İejimo varžos modulio dažninès charakteristikos, kai:

(a): $n=4, l_{1} / l_{2}=1$ ir: $1-Z_{\mathrm{B} 1} / Z_{\mathrm{B} 2}=1 ; 2-Z_{\mathrm{B} 1} / Z_{\mathrm{B} 2}=1,25 ; 3-Z_{\mathrm{B} 1} / Z_{\mathrm{B} 2}=1,5$;

(b): $Z_{\mathrm{B} 1} / Z_{\mathrm{B} 2}=1,5, l_{1} / l_{2}=1$ ir: $1-n=1 ; 2-n=2 ; 3-n=4$;

(c): $n=4, Z_{\mathrm{B} 1} / Z_{\mathrm{B} 2}=1,5$ ir: $1-l_{1} / l_{2}=1 ; 2-l_{1} / l_{2}=1,5 ; 3-l_{1} / l_{2}=2$

Fig. 2.21. Module of imput impedance versus frequency at:

(a): $n=4, l_{1} / l_{2}=1$ and: $1-Z_{\mathrm{B} 1} / Z_{\mathrm{B} 2}=1 ; 2-Z_{\mathrm{B} 1} / Z_{\mathrm{B} 2}=1.25 ; 3-Z_{\mathrm{B} 1} / Z_{\mathrm{B} 2}=1.5$;

(b): $Z_{\mathrm{B} 1} / Z_{\mathrm{B} 2}=1.5, l_{1} / l_{2}=1$ and: $1-n=1 ; 2-n=2 ; 3-n=4$;

(c): $n=4, Z_{\mathrm{B} 1} / Z_{\mathrm{B} 2}=1.5$ and: $1-l_{1} / l_{2}=1 ; 2-l_{1} / l_{2}=1.5 ; 3-l_{1} / l_{2}=2$ 
Beje, dèl periodinių netolygumų atsiranda ne vienintelè užtvarinė juosta. Kai $l_{1} \neq l_{2}$, užtvarinès juostos gaunamos ir ties kartotiniais dažniais $m f_{\mathrm{c}}$ (kai periode telpa sveikasis pusbangiu skaičius $m$ ).

Analogiški rezultatai gaunami ir su CST Microwave Studio ${ }^{\circledR}$ programų paketu skaičiuojant bendraašio kabelio iejjimo varžu charakteristikas (2.21 pav.). Didejjant periodų skaičiui ir didejjant nevienalytiškumo savybėms iejjimo varžų reikšmės ties užtvarine juosta auga.

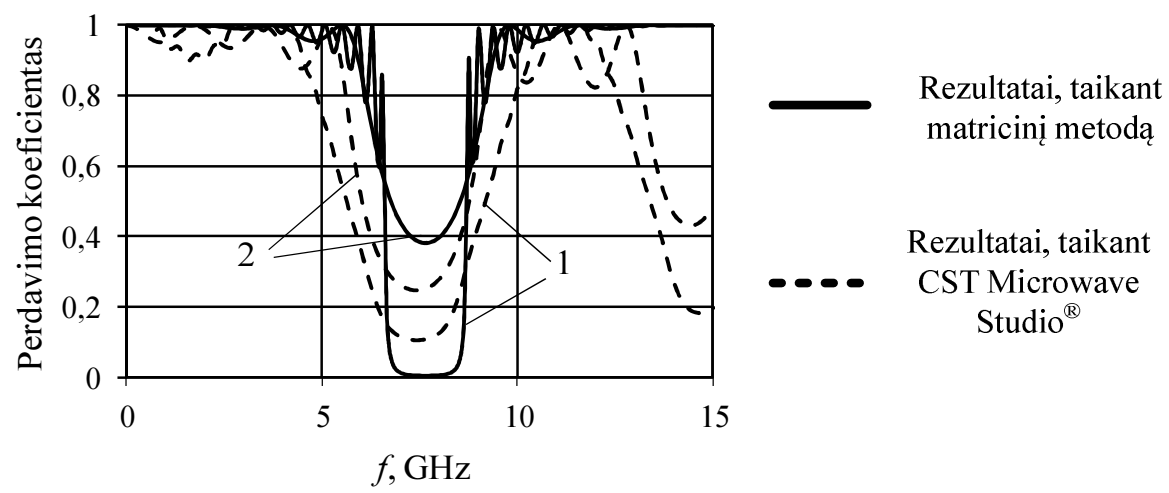

2.22pav. Ilgosios linijos perdavimo koeficientas, kai $R_{\mathrm{a}}=R_{\mathrm{i}}=50 \Omega, Z_{\mathrm{B} 1} / Z_{\mathrm{B} 2}=1,5$,

$$
l_{1} / l_{2}=1 \text {, ir: } 1-n=4 ; 2-n=16
$$

Fig. 2.22. Transfer coefficient of the transmission line at $R_{\mathrm{a}}=R_{\mathrm{i}}=50 \Omega, R_{\mathrm{a}}=R_{\mathrm{i}}=50 \Omega$,

$$
l_{1} / l_{2}=1, Z_{\mathrm{B} 1} / Z_{\mathrm{B} 2}=1.5 \text { and: } 1-n=4 ; 2-n=16
$$

Taigi, matriciniu metodu gautų nevienalytės periodinès sistemos dažninių charakteristikų priklausomybė nuo sistemos nevienalyčių periodų skaičiaus ir didejjančio sistemos periodinio nevienalytiškumo sutampa su baigtinių skirtumų laiko srities metodu CST Microwave Studio ${ }^{\circledR}$ programų paketo terpejje gautais rezultatais.

Didejjantis nevienalyčių periodų skaičius ir didèjantis periodinis nevienalytiškumas vienodai îtakoja užtvarinès juostos platejjimą abiem metodais. Visgi vykdomas metodų lyginimas yra kokybinis, nes sudėtinga CST Microwave Studio ${ }^{\circledR}$ programų pakete tiksliai nustatyti vienalyčių sričių bangines varžas. Patogiau nustatyti vienalyčių sričių banginių varžų verčių santykius. Tą patvirtina ir 2.22 paveiksle pateikti perdavimo koeficiento skaičiavimo rezultatai, gauti taikant matricini ir CST Microwave Studio ${ }^{\circledR}$ naudojamą baigtinių skirtumų laiko srities metodus. 


\subsection{Antrojo skyriaus išvados} das:

Remiantis atliktais tyrimais ir jų rezultatų analize galima daryti šias išva-

1. Parinktos ilgosios linijos iejjimo varžos bei perdavimo koeficiento dažninių charakteristiku skaičiavimo metodikos ir sudarytos skaičiavimo programos MATLAB $^{\circledR}$ terpejje tinka atskleisti nevienalytiškumo įtaką lètinimo sistemų savybèms.

2. Tyrimai parodè, kad kai elektromagnetinès bangos ilgis yra dvigubai didesnis už linijos periodo ilgi, dèl periodinių netolygumų iejjimo varžos dažninèse charakteristikose atsiranda maksimumai. Kai periode telpa sveikas pusbangių skaičius iejjimo varžos charakteristikų maksimumai gaunami ir ties kartotiniais dažniais.

3. Tyrimai parodè, kad taikant matricinị metodą galima ịvertinti dèl periodinių netolygumų dažninèje amplitudès charakteristikoje atsiradusią užtvarinę juostą, kurios centrinis dažnis priklauso nuo netolygumo periodo ilgio.

4. Tyrimai parodè, kad užtvarinès juostos plotis ir slopinimas joje didejja, jeigu: didèja linijos periodu skaičius; didèja periodo vienalyčiu atkarpu banginių varžų santykis ir vienalyčių atkarpų ilgių santykis periode artèja prie vieneto.

5. Užtvarinès juostos pločiui padidèjus nuo 5 iki $30 \%$, pereinamosios charakteristikos plokščiosios srities netolygumai išaugo 3 kartus. Toks žymus skirtumas gautas tik plokščiosios srities pradžioje ir tolstant nuo fronto sumažeja iki dviejų kartų.

6. Didejjant užtvarinès juostos pločiui nuo 5 iki $30 \%$ pereinamosios charakteristikos užaugimo frontas tapo nuožulnesnis ir jo fronto trukmè pailgèjo nuo 23,4 ps iki 29,6 ps, t. y. $26 \%$.

7. Sudarytų modelių tyrimų rezultatų adekvatumas parodytas taikant specializuotą programų paketą CST Microwave Studio ${ }^{\circledR}$, kuriame skaičiavimai vykdomi baigtinių skirtumų laiko srities metodu. 



\section{Lėtinimo sistemų savybių tyrimas}

Ankstesniame skyriuje nagrinètos linijos, kurių periodinių netolygumų skaičius buvo ribotas. Buvo pastebèta, kad linijos su periodiniais netolygumais užtvarinès juostos plotis praktiškai nebepriklauso nuo periodų skaičiaus, jeigu periodų skaičius pakankamai didelis. Atsižvelgdami i tai ir siekdami nustatyti, nuo ko priklauso užtvarinès juostos plotis be galo ilgose linijose, linijų su periodiniais netolygumais tyrimui pasitelksime daugialaidžių linijų metodą - pasinaudosime nevienalyčių spiralinių ir meandrinių sistemų modeliais.

Skyriuje tirsime turinčias periodinių netolygumų spiralines, meandrines ir hibridines lètinimo sistemas, jų užtvarines savybes ir jas lemiančius reiškinius. Daugialaidžių linijų metodais gautus rezultatus lyginsime su specializuotais programu paketais CST Microwave Studio ${ }^{\circledR}$ bei Sonnet ${ }^{\circledR}$ gautais rezultatais.

Skyriaus tema paskelbti penki autoriaus straipsniai (Katkevičius, Štaras 2009; Staras, Katkevičius 2010; Štaras, Katkevičius 2010; Daškevičius et al. 2010; Katkevičius, Štaras 2011). 


\subsection{Spiralinès konstrukcijos lètinimo sistemos modelis ir savybių analizè}

Šiame poskyryje analizuojamos spiralinės konstrukcijos turinčios periodiniu netolygumų lètinimo sistemos. Tiriama, kokios ịtakos spiralinėms lètinimo sistemoms, turinčioms periodiniu netolygumų, turi kintantis vienalyčiu sričių skaičius vijoje, kintantis vienalyčių sričių ilgių santykis arba kintantis vienalyčių sričių banginių varžų santykis. Irodoma, kad tokiose sistemose dèl periodinių netolygumų ir daugkartinių atspindžių nuo jų atsiranda dideli lètinimo koeficiento svyravimai bei susidaro užtvarinè juosta. Šiame poskyryje, siekiant atskleisti reiškinius, lemiančius spiralinès lètinimo sistemos (SLS) savybes, daugialaidžių liniju metodu sudaromas paprasčiausios sistemos modelis ir tiriama periodinių netolygumų įtaką sistemos lètinimo koeficientui, įejjimo varžai ir užtvarinès juostos pločiui.

\subsubsection{Spiralinès konstrukcijos lètinimo sistemos modelis}

3.1 paveiksle pateiktas supaprastintas stačiakampio formos spiralinès sistemos skersinio pjūvio vaizdas bei spiralinio laidininko fragmentas. Sistema ekranuota vidiniu ir išoriniu ekranais. Išilgai spiralinio laidininko esančių vienalyčiu sričių skaičius vijoje gali kisti. Tyrimuose naudojama spiraline sistema, turinti dvi arba keturias vienalytes sritis išilgai spiralinio laidininko vijos. Spiralinio laidininko matmenys, atstumai tarp greta esančių laidininkų arba tarp laidininkų ir jų vidinių bei išorinių ekranų gali kisti.

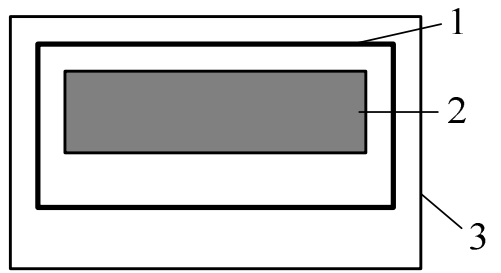

(a)

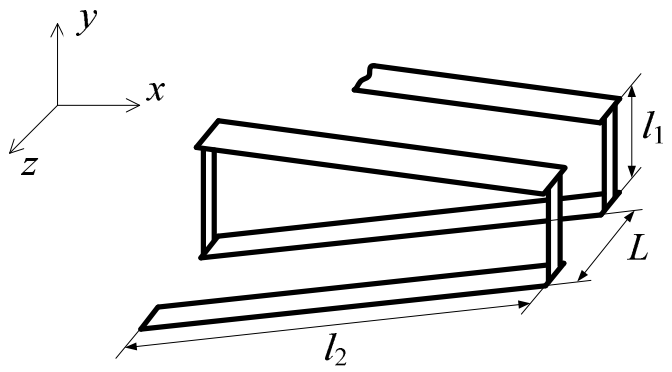

(b)

3.1 pav. Spiralinės sistemos skersinis pjūvis (a) ir spiralès fragmentas (b):

1 - spiralès laidininkas; 2 - vidinis ekranas; 3 - išorinis ekranas

Fig. 3.1. The cross-section of a helical system (a) and the view of the helix (b):

1 - helix; 2 - internal shield; 3 - external shield 
Kaip ir darbe (Štaras et al. 2012) turinčios periodinių netolygumų SLS analizei taikysime daugialaidžių linijų metodą. Paprasčiausias SLS modelis, turintis dvi vienalytes sritis išilgai laidininko vijos, pavaizduotas 3.2 paveiksle. Jị sudaro vieneilès vienpakopès daugialaidès linijos atkarpa ir ekranai.

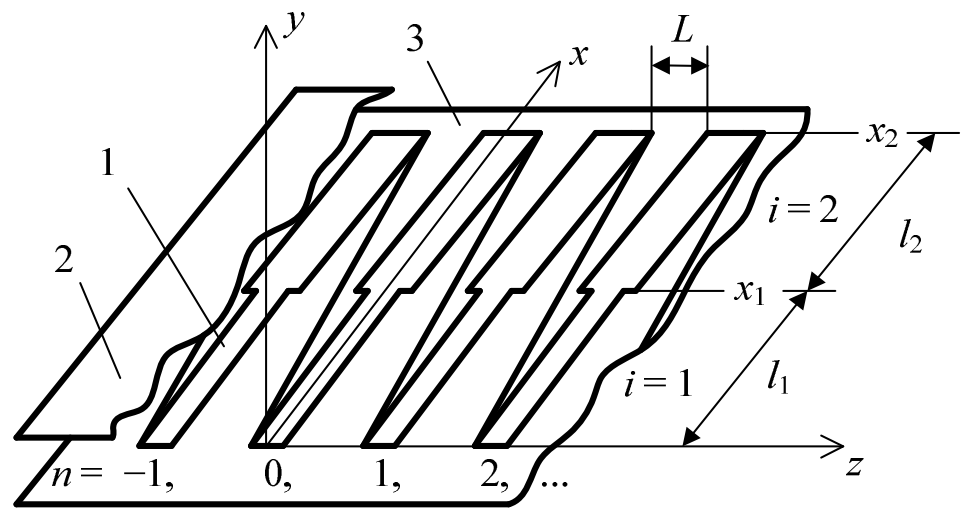

3.2 pav. Spiralinès sistemos modelis: 1 - daugialaidès linijos laidininkas; 2,3 - ekranai

Fig. 3.2. The model of the helical line: 1 - conductor of the multiconductor line;

2,3 - shields

Daugialaidès linijos laidininkų potencialai ir srovès išreiškiami lygtimis (Štaras et al. 2010):

$$
\begin{gathered}
\underline{U}_{i, n}(x)=\left(\underline{A}_{i, 1} \sin k x+\underline{A}_{i, 2} \cos k x\right) \mathrm{e}^{-\mathrm{j} n \theta}, \\
\underline{I}_{i, n}(x)=\mathrm{j} Y_{i}(\theta)\left(\underline{A}_{i, 1} \cos k x-\underline{A}_{i, 2} \sin k x\right) \mathrm{e}^{-\mathrm{j} n \theta},
\end{gathered}
$$

čia $\underline{A}_{\text {in }}$ - amplitudiniai koeficientai; $i$ - daugialaidès linijos laidininko segmento numeris $\left(i=1\right.$, kai $0<x<x_{1} ; i=2$, kai $\left.x_{1}<x<x_{2}\right) ; n$-laidininko numeris; $k$ - bangos skaičius, $\theta$ - gretimų daugialaides linijos laidininkų itampų ar srovių fazių skirtumas; $Y_{i}(\theta)$ - daugialaides linijos segmento banginis laidis.

3.2 paveiksle pateikta daugialaidès linijos atkarpa modeliuoja spiralinę sistemą, jei tenkinamos kraštinès sąlygos:

$$
\begin{gathered}
\underline{U}_{1, n}\left(x_{1}\right)=\underline{U}_{2, n}\left(x_{1}\right), \\
\underline{I}_{1, n}\left(x_{1}\right)=\underline{I}_{2, n}\left(x_{1}\right), \\
\underline{U}_{2, n}\left(x_{2}\right)=\underline{U}_{1,(n+1)}(0),
\end{gathered}
$$




$$
\underline{I}_{2, n}\left(x_{2}\right)=\underline{I}_{1,(n+1)}(0) \text {. }
$$

Irašę i kraštinių sąlygu lygtis (3.3)-(3.6) įtampų ir srovių išraiškas (3.1), (3.2), taikant matricinių ir iteracinių skaičiavimų principus gaunama lygčių sistema:

$$
\left\{\begin{array}{l}
\underline{A}_{21} \underline{D}_{11}+\underline{A}_{22} \underline{D}_{12}=0, \\
\underline{A}_{21} \underline{D}_{21}+\underline{A}_{22} \underline{D}_{22}=0,
\end{array}\right.
$$

čia

$$
\begin{aligned}
& \underline{D}_{11}=\left(\frac{Y_{2}(\theta)}{Y_{1}(\theta)} \cos k x_{2} \sin k x_{1}+\sin k x_{2} \cos k x_{1}\right) \mathrm{e}^{\mathrm{j} \theta}-\sin k x_{1}, \\
& \underline{D}_{12}=\left(-\frac{Y_{2}(\theta)}{Y_{1}(\theta)} \sin k x_{2} \sin k x_{1}+\cos k x_{2} \cos k x_{1}\right) \mathrm{e}^{\mathrm{j} \theta}-\cos k x_{1}, \\
& \underline{D}_{21}=\left(\cos k x_{2} \cos k x_{1}-\frac{Y_{1}(\theta)}{Y_{2}(\theta)} \sin k x_{2} \sin k x_{1}\right) \mathrm{e}^{\mathrm{j} \theta}-\cos k x_{1}, \\
& \underline{D}_{22}=\left(-\sin k x_{2} \cos k x_{1}-\frac{Y_{1}(\theta)}{Y_{2}(\theta)} \cos k x_{2} \sin k x_{1}\right) \mathrm{e}^{\mathrm{j} \theta}-\sin k x_{1} .
\end{aligned}
$$

Sprendžiant (3.7) lygčių sistemą gaunama sistemos dispersinè lygtis, kuriai galima suteikti pavidalą:

$$
\begin{aligned}
2 \cos \theta+\left(\frac{Y_{2}(\theta)}{Y_{1}(\theta)}+\frac{Y_{1}(\theta)}{Y_{2}(\theta)}\right) & \sin k x_{1} \sin k\left(x_{2}-x_{1}\right)- \\
& -2 \cos k x_{1} \cos k\left(x_{2}-x_{1}\right)=0 .
\end{aligned}
$$

Pareikalavus, kad lygčių sistemos (3.7) determinantas būtų lygus nuliui, arba sprendžiant dispersinę lygti (3.12), galima rasti bangos skaičių $k$, atitinkantị pasirinktą $\theta$ vertę. Tuomet galime naudoti lètinimo koeficiento ir dažnio išraiškas:

$$
\begin{gathered}
k_{L}=\mathrm{c}_{0} / v_{\mathrm{f}}=\theta / k L, \\
f=k c_{0} / 2 \pi,
\end{gathered}
$$

čia $v_{\mathrm{f}}$ - bègančiosios bangos fazinis greitis; $L$ - spiralès vijų ir daugialaidès linijos laidininkų žingsnis, $\mathrm{c}_{0}-$ šviesos greitis. 
Skaičiavimų metu banginių laidžių $Y_{i}(\theta)$ ir banginių varžų $Z_{i}(\theta)=1 / Y_{i}(\theta)$ vertès randamos remiantis formule (Štaras et al. 2012):

$$
Y_{i}(\theta)=Y_{i}(0)+\left[Y_{i}(\pi)-Y_{i}(0)\right] \sin ^{2}(\theta / 2) .
$$

Banginiai laidžiai $Y_{i}(0), Y_{i}(\pi)$ ir juos atitinkančios banginès varžos $Z_{i}(0)=1 / Y_{i}(0), Z_{i}(\pi)=1 / Y_{i}(\pi)$ gali būti nustatyti remiantis skaitiniais baigtinių skirtumų ar baigtinių elementų metodais (Štaras 2008).

Žinodami koeficientu $\underline{A}_{i 1}$ ir $\underline{A}_{i 2}$ sąryšius, galime rasti sistemos iejjimo varžos priklausomybę nuo koordinatès $x$ :

$$
\underline{Z}_{i}(x)=\underline{U}_{i 0}(x) / \underline{I}_{i 0}(x) .
$$

Kai išilgai spiralinio laidininko vijos yra keturios vienalytès sritys, sistemos modelis yra sudètingesnis. Vieneilès vienpakopès daugialaidès linijos atkarpa su vidiniu ir išoriniu ekranais, kai išilgai apvijos yra keturios vienalytės sritys, pavaizduota 3.3 paveiksle. Šiuo atveju daugialaidès linijos modelyje matomi keturi segmentai, kurių numeriai $i$ yra nuo vieno iki keturių ( $i=1$, kai $0<x<x_{1} ; i=2$, kai $x_{1}<x<x_{2} ; i=3$, kai $x_{2}<x<x_{3} ; i=4$, kai $x_{3}<x<x_{4}$ ).

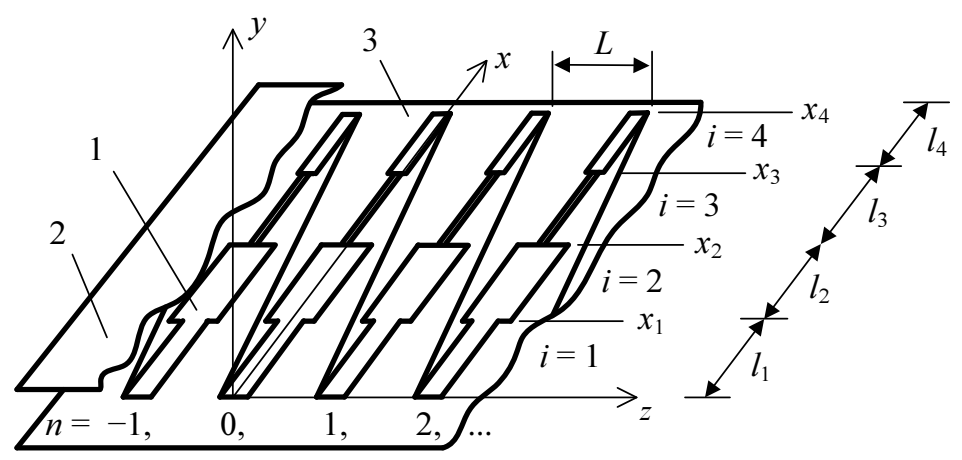

3.3 pav. Spiralinės sistemos modelis, kai laidininko vijoje yra keturios vienalytės sritys:

1 - daugialaidès linijos laidininkas; 2,3 - ekranai

Fig. 3.3. The model of the helical line with four homogenious sections: 1 - conductor of the multiconductor line; 2, 3 - shields

Didejjant vienalyčių sričių spiralès laidininko vijoje skaičiui turi būti tenkinamos papildomos kraštinès sąlygos:

$$
\begin{gathered}
\underline{U}_{1, n}\left(x_{1}\right)=\underline{U}_{2, n}\left(x_{1}\right), \\
\underline{I}_{1, n}\left(x_{1}\right)=\underline{I}_{2, n}\left(x_{1}\right),
\end{gathered}
$$




$$
\begin{gathered}
\underline{U}_{2, n}\left(x_{2}\right)=\underline{U}_{3, n}\left(x_{2}\right), \\
\underline{I}_{2, n}\left(x_{2}\right)=\underline{I}_{3, n}\left(x_{2}\right), \\
\underline{U}_{3, n}\left(x_{3}\right)=\underline{U}_{4, n}\left(x_{3}\right), \\
\underline{I}_{3, n}\left(x_{3}\right)=\underline{I}_{4, n}\left(x_{3}\right), \\
\underline{U}_{4, n}\left(x_{4}\right)=\underline{U}_{1,(n+1)}(0), \\
\underline{I}_{4, n}\left(x_{4}\right)=\underline{I}_{1,(n+1)}(0) .
\end{gathered}
$$

Toliau atliekami tie patys veiksmai, kaip ir tiriant spiralinị laidininką, kurio vijoje yra dvi vienalytès sritys. Irašius i kraštinių sąlygų lygtis (3.17) -(3.24) itampų ir srovių išraiškas (3.1), (3.2), gaunama lygčių sistema, kurią išsprendus gaunama sistemos dispersinè lygtis. Didejjant vienalyčių sričių skaičiui spiralinio laidininko vijoje sistemos dispersinès lygties išraiška tampa vis sudètingesnè.

Spiralinès sistemos charakteristikos - lètinimo koeficiento ir iejjimo varžos priklausomybès nuo dažnio - dažniausiai nagrinejjamos dažnių ruože, kai fazès kampas $\theta$ tarp gretimų laidininko viju itampų arba srovių kinta nuo 0 iki $\pi / 2$. Toks $\theta$ kitimo ruožo plotis nepakankamas informacijai apie užtvarinę juostą ir nevienalytės spiralinès struktūros užtvarines savybes gauti.

Užtvarinès savybės priklauso nuo laidininko vienalyčių sričių banginių laidžių arba varžų santykio. Šių parametrų priklausomybè nuo dažnio mažai tyrinèta. Be to, svarbu paminèti, kad esant skirtingiems fazès kampams $\theta=0$ arba $\theta=\pi$, banginių laidumų priklausomybę nuo dažnio lemia skirtingi faktoriai. Pavyzdžiui žemuose dažniuose banginè varža priklauso nuo daugialaidès linijos skersinių matmenų. Didejjant dažniui elektromagnetiniam laukui pasireiškia paviršinis efektas ir banginès varžos priklausomybè nuo sistemos ekranų mažeja. Tuo pačiu metu banginès varžos priklausomybẻ nuo žingsnio tarp gretimų spiralès vijų didèja. Atsižvelgiant ị tai, nagrinèjama, kaip nevienalytès SLS dažninès savybès priklauso nuo banginiu varžu kitimo išilgai spiralès vijos ir dažnio.

3.4 paveiksle pateiktas daugialaidžių linijų metodu modeliuojamos spiralinès lètinimo sistemos lètinimo koeficiento ir iejjimo varžos charakteristikų skaičiavimo algoritmas. Visu pirma įvedami daugialaidès linijos parametrai (1 blokas): linijos periodo ilgis, linijos vienalyčių atkarpu ilgiai, elektromagnetinès bangos sklidimo greičiai atkarpose ir atkarpų banginių bei apkrovos varžų vertès. Sudarius SLS lygčiu sistemą ir suformavus jos $\underline{A}$ koeficientų matricą (2 blokas) parenkama pradinė kampo $\theta$ tarp gretimų vijų laidininku ịtampų arba srovių vertè $\theta_{0}$ (3 blokas). Išsprendus daugialaide linija modeliuojamos SLS $\underline{A}$ koeficientų matricą (4 blokas) tikrinama, ar lygčių sistema turi sprendinių (5 blokas). 


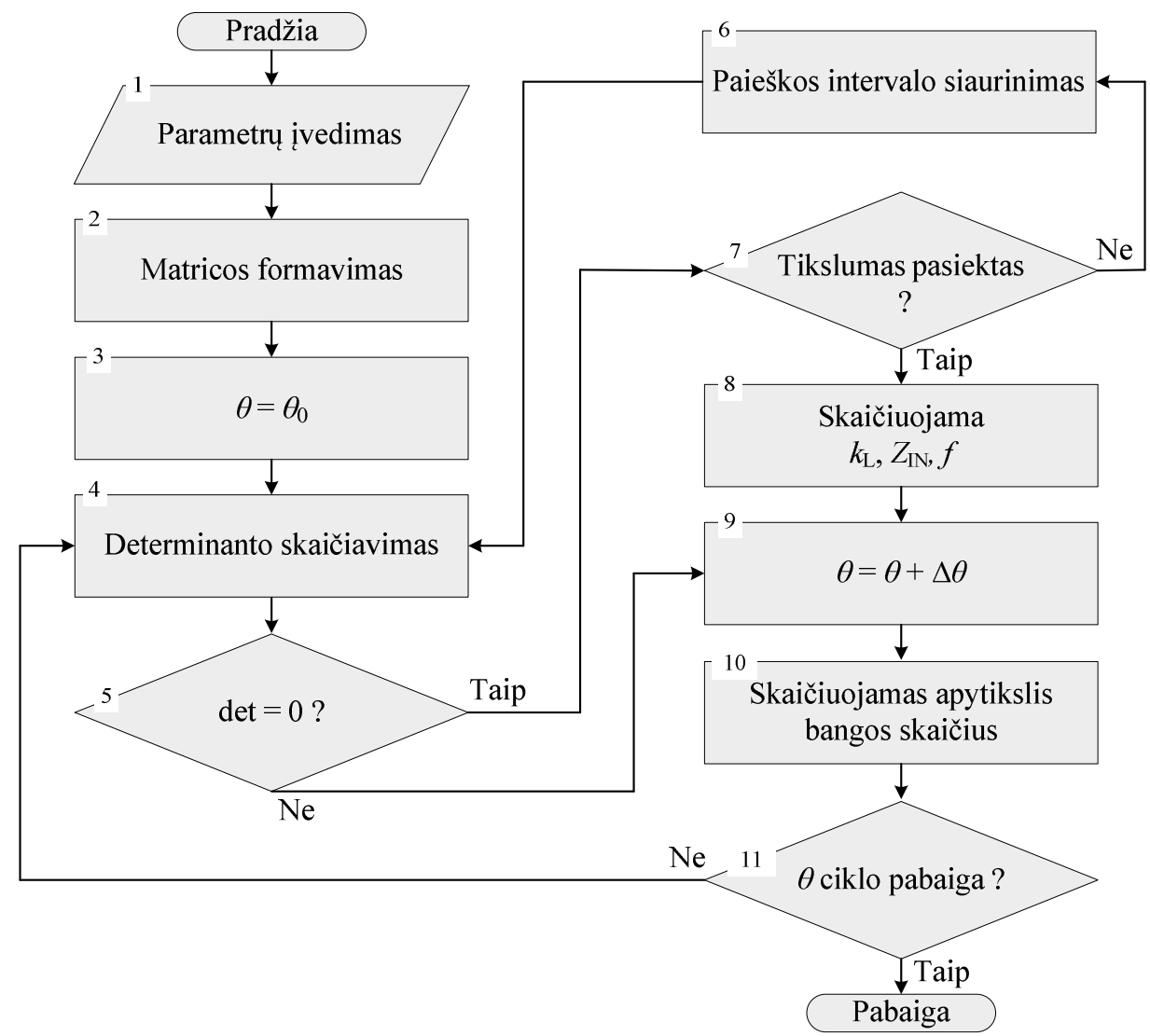

3.4 pav. Modeliuojamos daugialaide linija spiralinès lètinimo sistemos lètinimo koeficiento ir iejjimo varžos charakteristikų skaičiavimo algoritmas

Fig. 3.4. The algorithm of calculation of retardation factor and input impedance characteristics of the helical slow-wave system using multiconductor lines method

Jei sprendinys yra, tikrinama, ar jis tenkina nustatytą tikslumą ( 7 blokas). Jei tikslumas netenkinamas, siaurinamas sprendinio paieškos intervalas (6 blokas) ir priartejjimo metodu vèl ieškoma lygčiu sistemos sprendinio, kol pasiekiamas iš anksto pasirinktas tikslumas. Jei sprendinio tikslumas tenkinamas, skaičiuojama lètinimo koeficiento ir iejjimo varžos charakteristikos, atitinkančios tam tikrą konkretu dažni ( 8 blokas). Toliau $\theta$ verte didinama $\Delta \theta$ žingsniu ( 9 blokas) ir apsiskaičiuojamas šią vertę atitinkantis apytikslis bangos skaičius (10 blokas). Skaičiavimai vykdomi tol, kol baigiamas $\theta$ keitimo ciklas (11 blokas). Skaičiavimai vykdomi esant 120 skirtingų $\theta$ verčių. 


\subsubsection{Spiralinès konstrukcijos lètinimo sistemos savybių analizè}

Esant skirtingiems fazės kampams $\theta=0$ arba $\theta=\pi$, banginių laidžių priklausomybę nuo dažnio lemia skirtingi faktoriai. Atsižvelgiant ị tai nagrinèta, kaip turinčios periodinių netolygumu SLS dažninès savybès priklauso nuo banginių varžų kitimo išilgai spiralès vijos ir dažnio plačiame dažnių ruože.

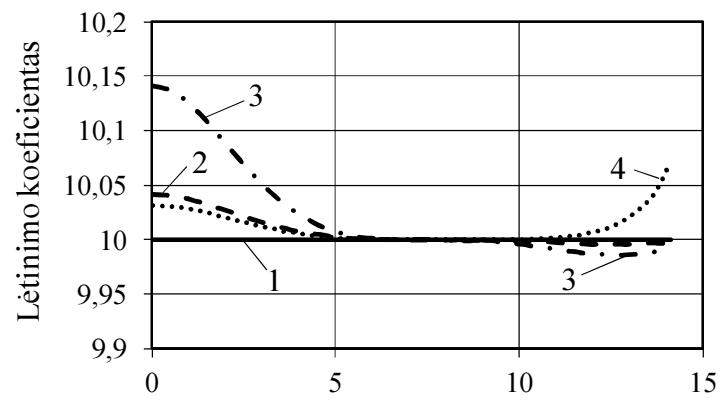

(a)

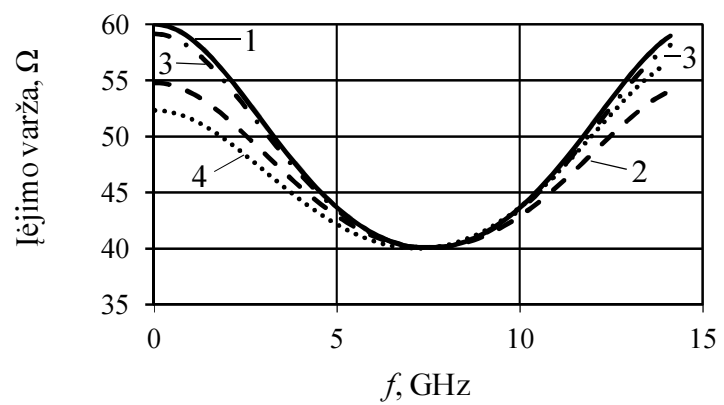

(b)

3.5 pav. Nevienalytès spiralinès lètinimo sistemos lètinimo koeficiento (a) ir ịejimo varžos (b) priklausomybė nuo dažnio, kintant lyginiam sužadinimui, kai $x_{2}=l_{1}+l_{2}=20 \mathrm{~mm}, L=2 \mathrm{~mm}$ ir:

$1-l_{1}=l_{2}=10 \mathrm{~mm}, \quad Z_{1}(0) / Z_{1}(\pi)=60 / 40 \Omega, Z_{2}(0) / Z_{2}(\pi)=60 / 40 \Omega$;

$2-l_{1}=l_{2}=10 \mathrm{~mm}, \quad Z_{1}(0) / Z_{1}(\pi)=60 / 40 \Omega, \quad Z_{2}(0) / Z_{2}(\pi)=50 / 40 \Omega$;

$3-l_{1}=l_{2}=10 \mathrm{~mm}, \quad Z_{1}(0) / Z_{1}(\pi)=70 / 40 \Omega, \quad Z_{2}(0) / Z_{2}(\pi)=50 / 40 \Omega$;

$4-l_{1} / l_{2}=5 / 15 \mathrm{~mm}, \quad Z_{1}(0) / Z_{1}(\pi)=60 / 40 \Omega, \quad Z_{2}(0) / Z_{2}(\pi)=50 / 40 \Omega$

Fig. 3.5. Retardation factor (a) and input impedance (b) versus frequency of the inhomogeneous helical slow-wave system then varies even excitation at $x_{2}=l_{1}+l_{2}=20 \mathrm{~mm}, L=2 \mathrm{~mm}$ and:

$1-l_{1}=l_{2}=10 \mathrm{~mm}, \quad Z_{1}(0) / Z_{1}(\pi)=60 / 40 \Omega, \quad Z_{2}(0) / Z_{2}(\pi)=60 / 40 \Omega$; $2-l_{1}=l_{2}=10 \mathrm{~mm}, \quad Z_{1}(0) / Z_{1}(\pi)=60 / 40 \Omega, \quad Z_{2}(0) / Z_{2}(\pi)=50 / 40 \Omega$; $3-l_{1}=l_{2}=10 \mathrm{~mm}, \quad Z_{1}(0) / Z_{1}(\pi)=70 / 40 \Omega, \quad Z_{2}(0) / Z_{2}(\pi)=50 / 40 \Omega$; $4-l_{1} / l_{2}=5 / 15 \mathrm{~mm}, \quad Z_{1}(0) / Z_{1}(\pi)=60 / 40 \Omega, \quad Z_{2}(0) / Z_{2}(\pi)=50 / 40 \Omega$ 
Remiamasi paprasčiausiais elektrodinaminès spiralinès lètinimo sistemos modeliais su kintančiu vienalyčių sričių skaičiumi išilgai spiralès vijos (3.2 pav.) ir (3.3 pav.).

3.5 paveiksle pateiktos lètinimo koeficiento ir iejjimo varžos priklausomybès nuo dažnio, kai spiralinès lètinimo sistemos laidininko viją sudaro dvi vienalytės sritys ir kinta banginių varžų santykis $Z_{i}(0)$ bei vienalyčių sričių ilgiai laidininko vijoje, o $Z_{i}(\pi)$ nekinta. Šiuo atveju, kai $Z_{i}(\pi)$ banginè varža pastovi, lètinimo koeficiento vertès plačiame dažnių ruože praktiškai nekinta. Dèl periodinio banginès varžos $Z_{i}(\theta)$ kitimo išilgai spiralès vijos lètinimo koeficiento vertès didejja. Jei $Z_{i}(\pi)$ pastovus, lètinimo koeficiento dispersiją galima sumažinti, mažinant banginès varžos $Z_{i}(0)$ kitimą ir trumpinant vienalytę sriti, kurios ilgis yra trumpesnis. Lètinimo koeficiento dispersija yra maksimali, kai $l_{2} / l_{1}=1$. Kai banginès varžos išilgai laidininko vijos nekinta, lètinimo koeficientas taip pat yra pastovus.

Spiralinès sistemos, turinčios periodinių netolygumu, ièjimo varža priklauso nuo fazès kampo $\theta$. Varža yra minimali, kai $\theta=\pi$, nes talpa tarp gretimų spiralès vijų yra maksimali.

Spiralinès sistemos dažninès charakteristikos (lètinimo koeficientas ir įejimo varža) kinta radikaliai, kai fazès kampas $\theta$ artimas $\pi$ ir išilgai spiralès vijos kinta banginè varža (3.6 pav.). Kai $\theta$ pasiekia $\pi$, elektromagnetinès bangos ilgis tampa dvigubai didesnis nei spiralès vijos ilgis ir susidaro užtvarinè juosta. Užtvarinès juostos centrinis dažnis priklauso nuo sistemos periodo vèlinimo laiko $t_{\mathrm{v}}$ ir išreiškiamas formule

$$
f_{\mathrm{c}}=\frac{1}{2 t_{\mathrm{v}}} .
$$

Užtvarinès juostos plotis priklauso nuo vienalyčių sričių banginių varžų $Z_{i}(\pi)$ santykio ir vienalyčių sričių ilgių santykio. Norint sumažinti vẻlinimo trukmès dispersiją ir užtvarinès juostos plotị, reikia sumažinti vienalyčių sričių banginių varžų verčių santykị ties $\theta=\pi$ ir sumažinti trumpesnès vienalytès srities ilgi.

Spiralinès lètinimo sistemos, turinčios periodinių netolygumų, iejjimo varža labai priklauso nuo koordinatès $x$ ir vienalyčiu sričiu ilgių santykio $l_{1}$ ir $l_{2}$ (3.6 pav. b, 4 kreivè).

3.7 paveiksle pateiktos spiralinès lètinimo sistemos dažninès charakteristikos, kai išilgai laidininko spiralès vijos yra dvi (3.2 pav) arba keturios (3.3 pav) vienalytės sritys. Lyginant pirmają ir antrają kreives 3.7 paveiksluose (a) ir (b) matyti, kad mažinant netolygumų periodą, galima išvengti užtvarinès juostos ties $\theta=\pi$, pagerinti spiralinès sistemos dispersines savybes ir sumažinti iejjimo varžos kitimą. 


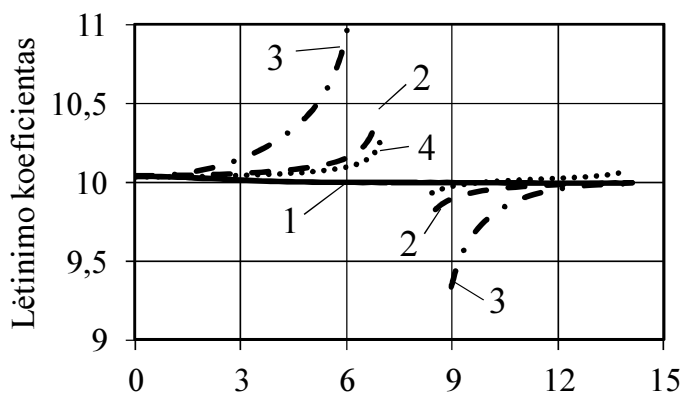

(a)

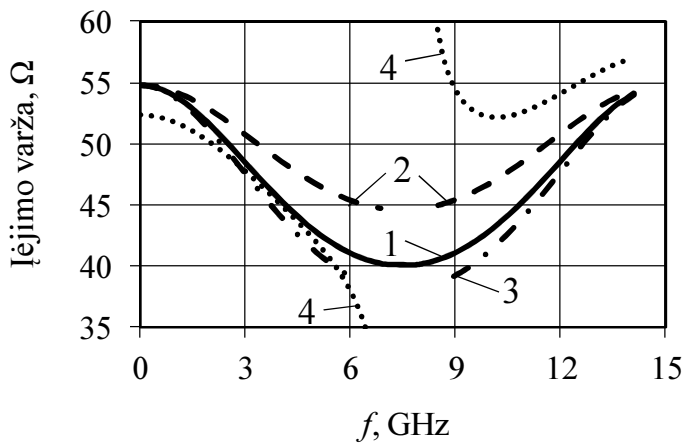

(b)

3.6 pav. Nevienalytès spiralinès lètinimo sistemos lètinimo koeficiento (a) ir ịejimo varžos (b) priklausomybė nuo dažnio, kintant lyginiam sužadinimui, kai $x_{2}=l_{1}+l_{2}=20 \mathrm{~mm}, L=2 \mathrm{~mm}$ ir:

$1-l_{1}=l_{2}=10 \mathrm{~mm}, \quad Z_{1}(0) / Z_{1}(\pi)=60 / 40 \Omega, \quad Z_{2}(0) / Z_{2}(\pi)=50 / 40 \Omega$;

$2-l_{1}=l_{2}=10 \mathrm{~mm}, \quad Z_{1}(0) / Z_{1}(\pi)=60 / 50 \Omega, \quad Z_{2}(0) / Z_{2}(\pi)=50 / 40 \Omega$;

$3-l_{1}=l_{2}=10 \mathrm{~mm}, \quad Z_{1}(0) / Z_{1}(\pi)=60 / 50 \Omega, Z_{2}(0) / Z_{2}(\pi)=50 / 30 \Omega$;

$4-l_{1} / l_{2}=5 / 15 \mathrm{~mm}, \quad Z_{1}(0) / Z_{1}(\pi)=60 / 50 \Omega, Z_{2}(0) / Z_{2}(\pi)=50 / 40 \Omega$

Fig. 3.6. Retardation factor (a) and input impedance (b) versus frequency of the inhomogeneous helical slow-wave system then varies odd excitation at $x_{2}=l_{1}+l_{2}=20 \mathrm{~mm}, L=2 \mathrm{~mm}$ and:

$1-l_{1}=l_{2}=10 \mathrm{~mm}, \quad Z_{1}(0) / Z_{1}(\pi)=60 / 40 \Omega, \quad Z_{2}(0) / Z_{2}(\pi)=50 / 40 \Omega$;

$2-l_{1}=l_{2}=10 \mathrm{~mm}, \quad Z_{1}(0) / Z_{1}(\pi)=60 / 50 \Omega, Z_{2}(0) / Z_{2}(\pi)=50 / 40 \Omega$;

$3-l_{1}=l_{2}=10 \mathrm{~mm}, \quad Z_{1}(0) / Z_{1}(\pi)=60 / 50 \Omega, \quad Z_{2}(0) / Z_{2}(\pi)=50 / 30 \Omega$;

$4-l_{1} / l_{2}=5 / 15 \mathrm{~mm}, \quad Z_{1}(0) / Z_{1}(\pi)=60 / 50 \Omega, Z_{2}(0) / Z_{2}(\pi)=50 / 40 \Omega$

Jei netolygumų periodas du kartus mažesnis, užtvarinè juosta atsiranda ties du kartus aukštesniais dažniais - ties $\theta \cong 2 \pi$.

Iš antrosios ir trečiosios kreivių palyginimo matyti, kad išilgai spiralès vijos turint du netolygumų periodus dispersija mažeja, kai mažinamas trumpesnès vienalytès srities ilgis ( 3.7 pav. a ir b). 


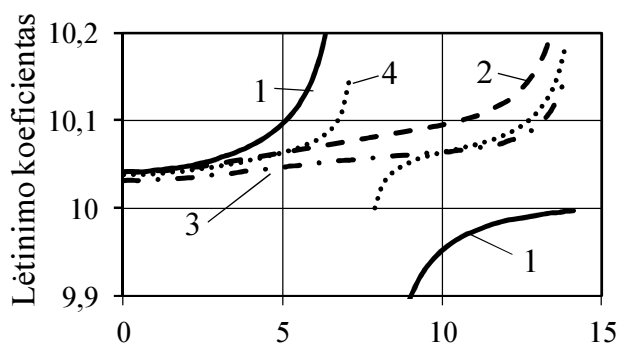

(a)

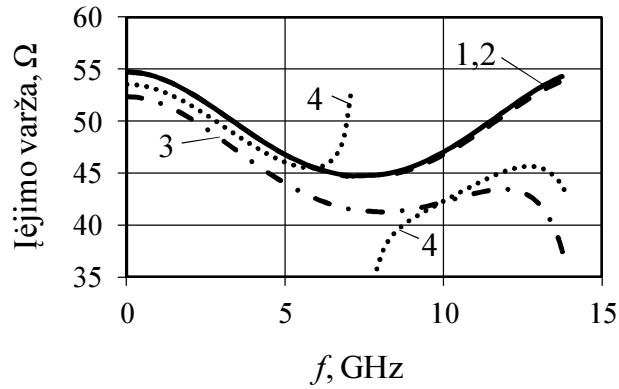

(b)

3.7 pav. Nevienalytès spiralinès lètinimo sistemos lètinimo koeficiento (a) ir ièjimo varžos (b) priklausomybe nuo dažnio, kai nevienalytiškumo periodą sudaro dvi arba keturios sritys ir kai $x_{4}=l_{1}+l_{2}+l_{3}+l_{4}=20 \mathrm{~mm}, L=2 \mathrm{~mm}$ ir:

$1-l_{1}=l_{3}=10 \mathrm{~mm}, \quad Z_{1}(0) / Z_{1}(\pi)=60 / 50 \Omega, Z_{2}(0) / Z_{2}(\pi)=60 / 50 \Omega$;

$l_{2}=l_{4}=0 \mathrm{~mm}, \quad Z_{3}(0) / Z_{3}(\pi)=50 / 40 \Omega, \quad Z_{4}(0) / Z_{4}(\pi)=50 / 40 \Omega$;

$2-l_{1}=l_{3}=5 \mathrm{~mm}, \quad Z_{1}(0) / Z_{1}(\pi)=60 / 50 \Omega, Z_{2}(0) / Z_{2}(\pi)=50 / 40 \Omega ;$

$l_{2}=l_{4}=5 \mathrm{~mm}, Z_{3}(0) / Z_{3}(\pi)=60 / 50 \Omega, Z_{4}(0) / Z_{4}(\pi)=50 / 40 \Omega ;$

$3-l_{1}=l_{3}=2,5 \mathrm{~mm}, Z_{1}(0) / Z_{1}(\pi)=60 / 50 \Omega, Z_{2}(0) / Z_{2}(\pi)=50 / 40 \Omega$;

$l_{2}=l_{4}=7,5 \mathrm{~mm}, \quad Z_{3}(0) / Z_{3}(\pi)=60 / 50 \Omega, Z_{4}(0) / Z_{4}(\pi)=50 / 40 \Omega ;$

$4-l_{1} / l_{3}=2,5 / 7,5 \mathrm{~mm}, Z_{1}(0) / Z_{1}(\pi)=60 / 50 \Omega, Z_{2}(0) / Z_{2}(\pi)=60 / 50 \Omega$;

$l_{2}=l_{4}=5 \mathrm{~mm}, Z_{3}(0) / Z_{3}(\pi)=50 / 40 \Omega, Z_{4}(0) / Z_{4}(\pi)=50 / 40 \Omega$

Fig. 3.7. Retardation factor (a) and input impedance (b) versus frequency of the inhomogeneous helical slow-wave system then inhomogeneous period consist of two or four sections at $x_{4}=l_{1}+l_{2}+l_{3}+l_{4}=20 \mathrm{~mm}, L=2 \mathrm{~mm}$ and:

$1-l_{1}=l_{3}=10 \mathrm{~mm}, \quad Z_{1}(0) / Z_{1}(\pi)=60 / 50 \Omega, Z_{2}(0) / Z_{2}(\pi)=60 / 50 \Omega$;

$l_{2}=l_{4}=0 \mathrm{~mm}, \quad Z_{3}(0) / Z_{3}(\pi)=50 / 40 \Omega, \quad Z_{4}(0) / Z_{4}(\pi)=50 / 40 \Omega ;$

$2-l_{1}=l_{3}=5 \mathrm{~mm}, \quad Z_{1}(0) / Z_{1}(\pi)=60 / 50 \Omega, \quad Z_{2}(0) / Z_{2}(\pi)=50 / 40 \Omega$;

$l_{2}=l_{4}=5 \mathrm{~mm}, \quad Z_{3}(0) / Z_{3}(\pi)=60 / 50 \Omega, Z_{4}(0) / Z_{4}(\pi)=50 / 40 \Omega ;$

$3-l_{1}=l_{3}=2.5 \mathrm{~mm}, \quad Z_{1}(0) / Z_{1}(\pi)=60 / 50 \Omega, Z_{2}(0) / Z_{2}(\pi)=50 / 40 \Omega$;

$l_{2}=l_{4}=7.5 \mathrm{~mm}, \quad Z_{3}(0) / Z_{3}(\pi)=60 / 50 \Omega, Z_{4}(0) / Z_{4}(\pi)=50 / 40 \Omega ;$

$4-l_{1} / l_{3}=2.5 / 7.5 \mathrm{~mm}, Z_{1}(0) / Z_{1}(\pi)=60 / 50 \Omega, Z_{2}(0) / Z_{2}(\pi)=60 / 50 \Omega$;

$l_{2}=l_{4}=5 \mathrm{~mm}, \quad Z_{3}(0) / Z_{3}(\pi)=50 / 40 \Omega, Z_{4}(0) / Z_{4}(\pi)=50 / 40 \Omega$ 
Svarbu paminèti, kad kai $Z_{1}(\theta) \neq Z_{3}(\theta), Z_{2}(\theta) \neq Z_{4}(\theta)$ arba $l_{1}=l_{3}$ ir $l_{2}=l_{4}$ (3.7 pav. a ir b, 4 kreivè), užtvarinè juosta yra ties $\theta=\pi$, nors spiralinè sistema ir turi keturias vienalytes sritis išilgai laidininko vijos. Šiuo atveju netolygumu periodas yra tokio ilgio kaip ir spiralès vija ir centrinis užtvarinès juostos dažnis nustatomas remiantis (3.25) formule.

Kaip jau buvo minèta, realiose sistemose nuostoliai neišvengiami. Išskiriami nuostoliai laidininkuose, dielektrikuose, išspinduliavimo nuostoliai. Darbe (Štaras et al. 2012) nustatyta, kad varžiniai nuostoliai laidininkuose dideja kvadratinès šaknies iš dažnio priklausomybe. Be to, nustatyta, kad dielektriniai nuostoliai nepriklauso nuo skerspjūvio matmenų, bet didejja tiesine priklausomybe didejjant dažniui (3.8 pav.). Spinduliavimo nuostoliai visa eile mažesni nei varžiniai ar dielektriniai nuostoliai, todèl jų nevertinsime. Nuostolius sistemoje patogu įvertinti remiantis dažninès amplitudès charakteristikos perdavimo koeficientu (3.8 pav. b).

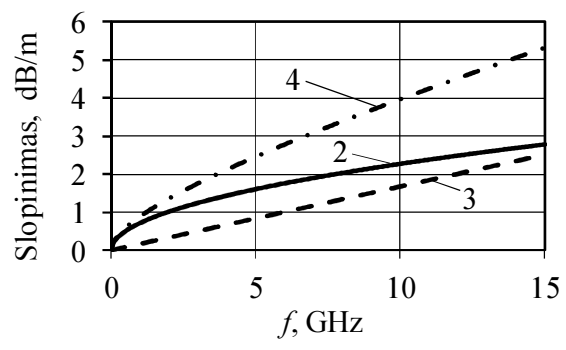

(a)

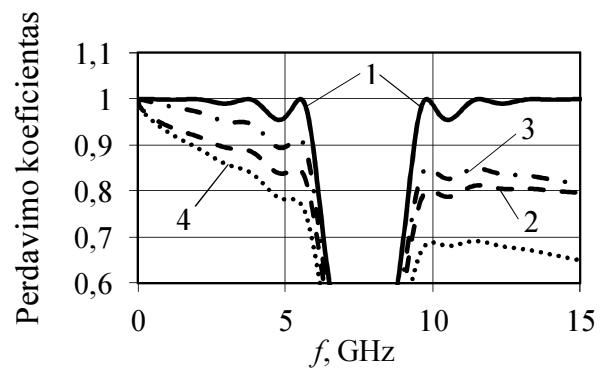

(b)

3.8 pav. Slopinimo itakos ịvertinimas (a) ir ilgosios linijos perdavimo koeficientas (b), kai $n=4, l_{1}=l_{2}=10 \mathrm{~mm}, Z_{\mathrm{B} 1}=40 \Omega, Z_{\mathrm{B} 2}=60 \Omega, R_{\mathrm{a}}=R_{\mathrm{i}}=50 \Omega$, ir vertinama:

1 - be nuostoliu; 2 - nuostoliai laidininkuose; 3 - nuostoliai dielektrikuose; 4 - suminiai nuostoliai

Fig. 3.8. Evaluating the impact of suppression (a) and transfer coefficient of the transmission line model (b) then $n=4, l_{1}=l_{2}=10 \mathrm{~mm}, Z_{\mathrm{B} 1}=40 \Omega, Z_{\mathrm{B} 2}=60 \Omega$, $R_{\mathrm{a}}=R_{\mathrm{i}}=50 \Omega$ and: 1 - without loss; 2 - loss in conductors; 3 - loss in dielectrics; 4 - total loss

3.8 paveiksle pateikti dažninių amplitudès charakteristikų rezultatai, kai ilgają perdavimo liniją sudaro 4 nevienalytiškumo periodai, vienalyčių sričiu ilgiai yra vienodi, šaltinio ir apkrovos varžos yra vienodos ir lygios $50 \Omega$. Iš rezultatų matyti, kad realiose sistemose reikia atsižvelgti i slopinimą laidininkuose ir dielektrikuose. Slopinimas laidininkuose turi didesnès įtakos žemuosiuose ir vidutiniuose dažniuose, o slopinimas dielektrikuose - aukštesniuose dažniuose (3.8 pav. b). 


\subsection{Meandrinès konstrukcijos lëtinimo sistemos modelis ir savybių analizè}

Šiame poskyryje nagrinejjama meandrinès konstrukcijos turinčios periodinių netolygumų lètinimo sistemų savybès. Dažniausiai literatūroje analizuojamos meandrinès konstrukcijos lètinimo sistemų, kai sistema yra simetriška per centrinę laidininko dali einančios statmenos plokštumos atžvilgiu, savybès. Skersinis asimetriškumas gali atsirasti dèl gamybos broko ir kitų priežasčių. Asimetrinio meandro elektrodo fragmento pavyzdys pateiktas 3.9 paveiksle. Dél gamybinio broko kraštinių sričių storiai skiriasi arba centrinè meandro dalis gali būti pastumta link vieno iš kraštų $\left(l_{1} \neq l_{3}\right)$. Dèl asimetrinių netolygumų gali susiaurèti meandrinès sistemos pralaidumo juosta. Skersinio asimetriškumo įtaka išnagrinèta nepakankamai, todèl šiame skyriuje, taikant daugialaidžių linijų metodą, pateikiami rezultatai, atskleidžiantys skersinio asimetriškumo įtaka meandrinès konstrukcijos lètinimo sistemos dažninèms savybėms.

\subsubsection{Meandrinès konstrukcijos lètinimo sistemos modelis}

Asimetriško meandrinio laidininko fragmentas pateiktas 3.9 paveiksle. Meandro elektrodą sudaro trys vienalytės sritys: platesnè centrinè dalis ir siauresnès kraštinès dalys. Tokios struktūros meandrinių lètinimo sistemų analizei taikysime daugialaidžių linijų metodą. Sudarysime meandrinès lètinimo sistemos (MLS), turinčios asimetrinių netolygumų, modelị ir ištirsime jos dažnines savybes.

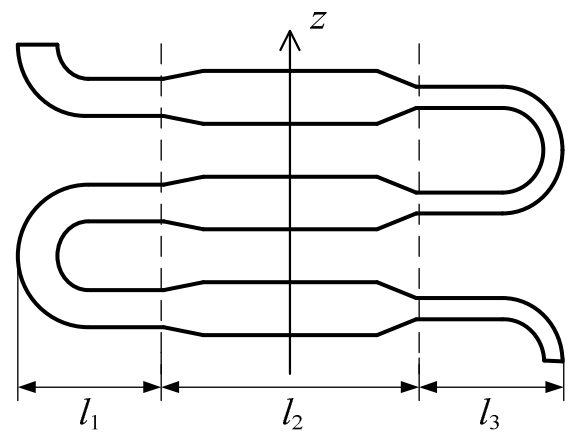

3.9 pav. Asimetriško meandrinio laidininko fragmentas

Fig. 3.9. The fragmento of the asymmetrical meander electrode

Iš daugialaidžių linijų sudarytas turinčios skersinį asimetriškumą meandrinès lètinimo sistemos modelis pateiktas 3.10 paveiksle. Jị sudaro vieneilès vienpakopès daugialaidès linijos atkarpos ir ekranai. 3.10 paveiksle $n$ yra laidininko 
eilès numeris, $L$ - žingsnis tarp gretimų spiralès laidininkų, $l_{1}, l_{2}, l_{3}$ - vienalyčių sričių ilgiai. Viename netolygumu periode yra trys vienalytès sritys. Remiantis (Štaras et al. 2012), daugialaidès linijos laidininkų potencialai ir srovès išreiškiami lygtimis:

$$
\begin{gathered}
\underline{U}_{i, n}(x)=\left(\underline{A}_{i} \sin k x+\underline{B}_{i} \cos k x\right) \mathrm{e}^{-\mathrm{j} n \theta}+ \\
\left(\underline{C}_{i} \sin k x+\underline{D}_{i} \cos k x\right) \mathrm{e}^{-\mathrm{j} n(\theta+\pi),} \\
\underline{I}_{i, n}(x)=\mathrm{j} Y_{i}(\theta)\left(\underline{A}_{i} \cos k x-\underline{B}_{i} \sin k x\right) \mathrm{e}^{-\mathrm{j} n \theta}+ \\
\mathrm{j} Y_{i}(\theta+\pi)\left(\underline{C}_{i} \cos k x-\underline{D}_{i} \sin k x\right) \mathrm{e}^{-\mathrm{j} n(\theta+\pi),}
\end{gathered}
$$

čia $\underline{A}_{i}, \underline{B}_{i}, \underline{C}_{i}, \underline{D}_{i}$ - amplitudiniai koeficientai; $i$ - daugialaidès linijos vienalytès srities numeris; $n$-laidininko numeris eilèje; $k=\omega / \mathrm{c}_{0}$-bangos skaičius; $\omega$ - kampinis dažnis; $\mathrm{c}_{0}-$ šviesos greitis vakuume; $x$ - koordinaté; $\theta$ - itampos arba srovès fazès skirtumas tarp gretimų laidininkų; $Y(\theta)$ ir $Y(\theta+\pi)$ - daugialaidès linijos banginiai laidžiai.

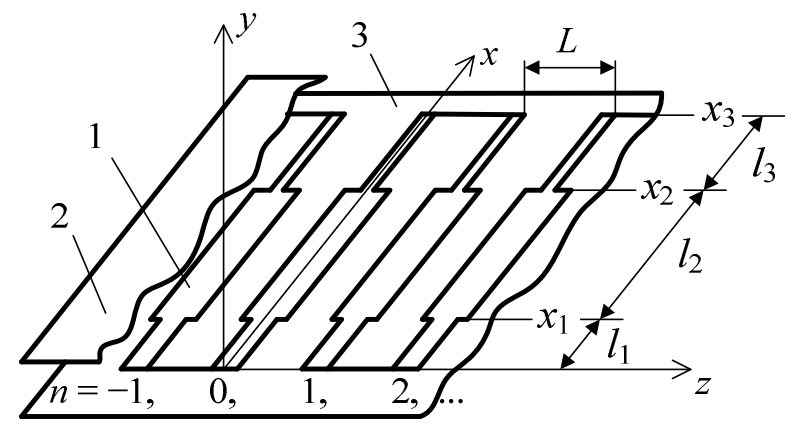

3.10 pav. Nevienalytès meandrinès linijos modelis: 1 - daugialaidès linijos laidininkas; 2, 3 - ekranai

Fig. 3.10. The model of the inhomogeneous meander slow-wave systems: 1 - conductor of the multiconductor line; 2,3 - shields

3.10 paveiksle pateikta struktūra modeliuoja meandrinę sistemą, jei tenkinamos šios kraštinès sąlygos:

$$
\begin{gathered}
\underline{U}_{1, n}(0)=\underline{U}_{1,(n-1)}(0), \underline{I}_{1, n}(0)=-\underline{I}_{1,(n-1)}(0), \\
\underline{U}_{1, n}\left(x_{1}\right)=\underline{U}_{2, n}\left(x_{1}\right), \underline{I}_{1, n}\left(x_{1}\right)=\underline{I}_{2, n}\left(x_{1}\right),
\end{gathered}
$$




$$
\begin{gathered}
\underline{U}_{2, n}\left(x_{2}\right)=\underline{U}_{3, n}\left(x_{2}\right), \underline{I}_{2, n}\left(x_{2}\right)=\underline{I}_{3, n}\left(x_{2}\right), \\
\underline{U}_{3, n}\left(x_{3}\right)=\underline{U}_{3,(n+1)}\left(x_{3}\right), \underline{I}_{3, n}\left(x_{3}\right)=-\underline{I}_{3,(n+1)}\left(x_{3}\right), \\
\underline{U}_{1,(n+1)}\left(x_{1}\right)=\underline{U}_{2,(n+1)}\left(x_{1}\right), \underline{I}_{1,(n+1)}\left(x_{1}\right)=\underline{I}_{2,(n+1)}\left(x_{1}\right), \\
\underline{U}_{2,(n+1)}\left(x_{2}\right)=\underline{U}_{3,(n+1)}\left(x_{2}\right), \underline{I}_{2,(n+1)}\left(x_{2}\right)=\underline{I}_{3,(n+1)}\left(x_{2}\right) .
\end{gathered}
$$

Irašę (3.26) ir (3.27) ịtampų ir srovių išraiškas i kraštinių sąlygų formules (3.28)-(3.33) gauname algebrinę lygčių sistemą. Eliminavę koeficientus $\underline{A}_{i 1}$ ir $\underline{A}_{i 2}$ gauname dispersinę lygtị. Sprendžiant dispersinę lygti galima rasti bangos skaičių $k$, atitinkantị pasirinktą $\theta$ vertę. Tuomet lètinimo koeficiento $k_{\mathrm{L}}$ ir dažnio $f$ išraiškos:

$$
\begin{gathered}
k_{L}=\mathrm{c}_{0} / v_{f}=\theta / k L, \\
f=k \mathrm{c}_{0} / 2 \pi,
\end{gathered}
$$

čia $v_{\mathrm{f}}$ - bėgančiosios bangos fazinis greitis; $\mathrm{c}_{0}-$ šviesos greitis; $L$ - žingsnis tarp gretimų meandro laidininkų.

Meandrinès sistemos iejjimo varža $Z_{\mathrm{IN}}$ priklauso nuo koordinatès $x$. Kai $x=0$, atsižvelgiant ị ịtampų (3.26) ir srovių (3.27) išraiškas

$$
\underline{Z}_{\mathrm{IN}}(0)=\frac{\underline{U}_{0}(0)}{\underline{I}_{0}(0)}=\frac{1}{\mathrm{j}} \cdot \frac{A_{12}+A_{14}}{Y(\theta) \cdot A_{11}+Y(\theta+\pi) \cdot A_{13}} .
$$

Skaičiavimu metu banginių laidžių $Y(\theta)$ ir $Y(\theta+\pi)$ vertès randamos remiantis formule (Štaras et al. 2012):

$$
Y_{i}(\theta)=Y_{i}(0)+\left[Y_{i}(\pi)-Y_{i}(0)\right] \sin ^{2}(\theta / 2) .
$$

Banginiai laidžiai $Y_{i}(\theta), Y_{i}(\pi)$ ir juos atitinkančios banginès varžos $Z_{i}(0)=1 / Y_{i}(0), Z_{i}(\pi)=1 / Y_{i}(\pi)$ randami remiantis skaitiniais baigtinių skirtumų ir baigtinių elementų metodais (Bhobe 2001).

\subsubsection{Meandrinès konstrukcijos lètinimo sistemos savybių analizè}

3.11 paveiksle pateiktos MLS dažninès lètinimo koeficiento ir iejjimo varžos charakteristikos, kai sistemos nevienalytiškumo periodą sudaro trys vienalytès sritys bei meandro elektrodas yra simetriškas per centrinę dali einančios statmenos plokštumos atžvilgiu. Kai meandro laidininko banginès varžos visose trijose 
srityse yra vienodos, t. y. sistema vienalytè, dažninėse MLS charakteristikose trūkių nèra (3.11 pav. a ir b, 1 kreivè). Vienalytės meandrinès sistemos pasižymi didele lètinimo koeficiento dispersija ir mažu iejjimo varžos kitimu.

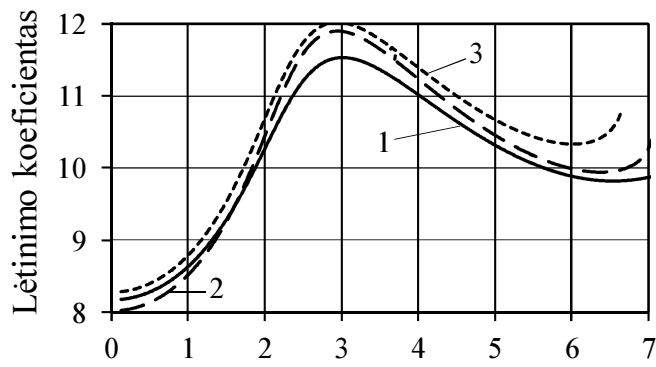

(a)

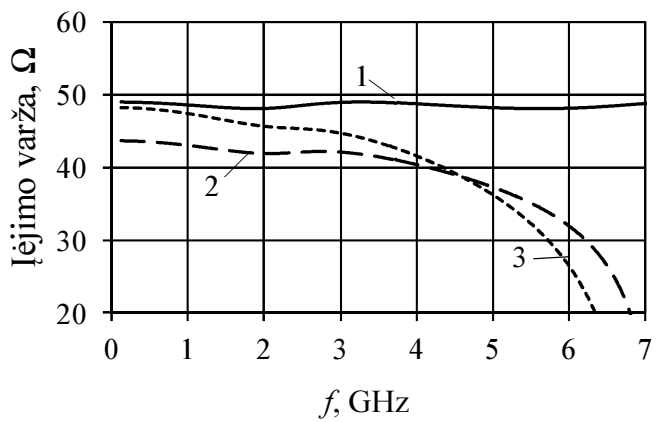

(b)

3.11 pav. Nevienalytės meandrinès lètinimo sistemos be skersinio asimetriškumo lètinimo koeficiento (a) ir ịejjimo varžos (b) priklausomybè nuo dažnio, kai $x_{3}=l_{1}+l_{2}+l_{3}=20 \mathrm{~mm}, l_{1}=l_{3}=5 \mathrm{~mm}, l_{2}=10 \mathrm{~mm}, L=2 \mathrm{~mm}$ ir:

$1-Z_{1}(0) / Z_{1}(\pi)=60 / 40 \Omega, Z_{2}(0) / Z_{2}(\pi)=60 / 40 \Omega, Z_{3}(0) / Z_{3}(\pi)=60 / 40 \Omega$;

$2-Z_{1}(0) / Z_{1}(\pi)=60 / 40 \Omega, \quad Z_{2}(0) / Z_{2}(\pi)=50 / 30 \Omega, \quad Z_{3}(0) / Z_{3}(\pi)=60 / 40 \Omega$;

$3-Z_{1}(0) / Z_{1}(\pi)=70 / 50 \Omega, \quad Z_{2}(0) / Z_{2}(\pi)=50 / 30 \Omega, \quad Z_{3}(0) / Z_{3}(\pi)=70 / 50 \Omega$

Fig. 3.11. Retardation factor (a) and input impedance (b) versus frequency of the inhomogeneous meander slow-wave system without transverse asymmetry at $x_{3}=l_{1}+l_{2}+l_{3}=20 \mathrm{~mm}, l_{1}=l_{3}=5 \mathrm{~mm}, l_{2}=10 \mathrm{~mm}, L=2 \mathrm{~mm}$ and:

$1-Z_{1}(0) / Z_{1}(\pi)=60 / 40 \Omega, \quad Z_{2}(0) / Z_{2}(\pi)=60 / 40 \Omega, \quad Z_{3}(0) / Z_{3}(\pi)=60 / 40 \Omega$;

$2-Z_{1}(0) / Z_{1}(\pi)=60 / 40 \Omega, \quad Z_{2}(0) / Z_{2}(\pi)=50 / 30 \Omega, \quad Z_{3}(0) / Z_{3}(\pi)=60 / 40 \Omega$;

$3-Z_{1}(0) / Z_{1}(\pi)=70 / 50 \Omega, \quad Z_{2}(0) / Z_{2}(\pi)=50 / 30 \Omega, Z_{3}(0) / Z_{3}(\pi)=70 / 50 \Omega$

Siekiant pagerinti bėgančiosios bangos vabzdžiu jautrumą bei padidinti signalų trakto varžą bègančiosios bangos kreipimo sistemose praplatinama meandrinio elektrodo centrinè dalis bei siaurinamos periferinès dalys. Tokios MLS dažnines charakteristikas iliustruoja 3.11 paveikslų (a) ir (b) 2-osios kreivès. Sistemos iejjimo varža radikaliai kinta ir susiformuoja užtvarinè juosta, kai fazès kampas $\theta \operatorname{tarp}$ gretimų laidininkų įtampų ir srovių pasiekia $\pi$, o dažnis pasiekia 


$$
f_{\mathrm{c}}(\pi)=\frac{1}{2 t_{\mathrm{v}}}
$$

čia $t_{\mathrm{v}} \cong L_{\mathrm{S}} k_{\mathrm{L}} / \mathrm{c}_{0}-$ vèlinimo trukmè; $L_{\mathrm{S}}-$ lètinimo sistemos ilgis.

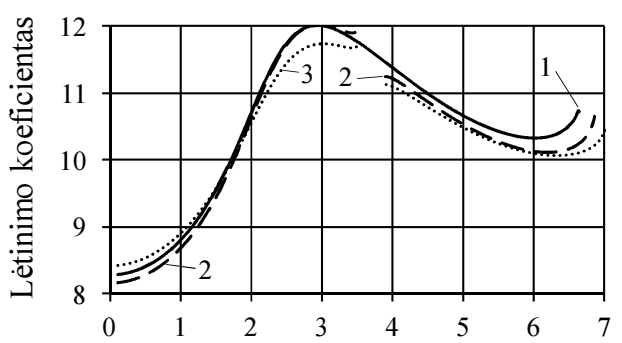

(a)

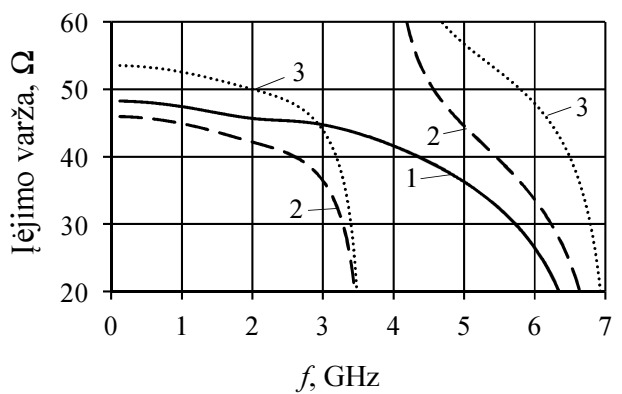

(b)

3.12 pav. Nevienalytès meandrinès lètinimo sistemos su skersiniu asimetriškumu lètinimo koeficiento (a) ir įejimo varžos (b) priklausomybè nuo dažnio, kai

$$
x_{3}=l_{1}+l_{2}+l_{3}=20 \mathrm{~mm}, L=2 \mathrm{~mm} \text { ir: }
$$

1 - simetriškas meandras: $l_{1}=5 \mathrm{~mm}, l_{2}=10 \mathrm{~mm}, l_{3}=5 \mathrm{~mm}$;

$Z_{1}(0) / Z_{1}(\pi)=70 / 50 \Omega, Z_{2}(0) / Z_{2}(\pi)=50 / 30 \Omega, Z_{3}(0) / Z_{3}(\pi)=70 / 50 \Omega$;

2 - kinta kraštinių sričių banginès varžos: $l_{1}=5 \mathrm{~mm}, l_{2}=10 \mathrm{~mm}, l_{3}=5 \mathrm{~mm}$;

$Z_{1}(0) / Z_{1}(\pi)=70 / 50 \Omega, Z_{2}(0) / Z_{2}(\pi)=50 / 30 \Omega, Z_{3}(0) / Z_{3}(\pi)=60 / 40 \Omega$;

3 - centriné dalis pastumta ị vieną iš kraštu, $l_{1}=5 \mathrm{~mm}, l_{2}=5 \mathrm{~mm}, l_{3}=10 \mathrm{~mm}$;

$Z_{1}(0) / Z_{1}(\pi)=70 / 50 \Omega, Z_{2}(0) / Z_{2}(\pi)=50 / 30 \Omega, Z_{3}(0) / Z_{3}(\pi)=70 / 50 \Omega$

Fig. 3.12. Retardation factor (a) and input impedance (b) versus frequency of the inhomogeneous meander slow-wave system with transverse asymmetry at $x_{3}=l_{1}+l_{2}+l_{3}=20 \mathrm{~mm}, L=2 \mathrm{~mm}$ and:

1 - without transverse asymmetry: $l_{1}=5 \mathrm{~mm}, l_{2}=10 \mathrm{~mm}, l_{3}=5 \mathrm{~mm}$; $Z_{1}(0) / Z_{1}(\pi)=70 / 50 \Omega, Z_{2}(0) / Z_{2}(\pi)=50 / 30 \Omega, Z_{3}(0) / Z_{3}(\pi)=70 / 50 \Omega$;

2 - varies characteristic impedances of edge areas: $l_{1}=5 \mathrm{~mm}, l_{2}=10 \mathrm{~mm}, l_{3}=5 \mathrm{~mm}$; $Z_{1}(0) / Z_{1}(\pi)=70 / 50 \Omega, Z_{2}(0) / Z_{2}(\pi)=50 / 30 \Omega, Z_{3}(0) / Z_{3}(\pi)=60 / 40 \Omega$;

3 - central part shifted to one of the edges: $l_{1}=5 \mathrm{~mm}, l_{2}=5 \mathrm{~mm}, l_{3}=10 \mathrm{~mm}$; $Z_{1}(0) / Z_{1}(\pi)=70 / 50 \Omega, Z_{2}(0) / Z_{2}(\pi)=50 / 30 \Omega, Z_{3}(0) / Z_{3}(\pi)=70 / 50 \Omega$ 
Didejjant banginių varžų $Z(0)$ ir $Z(\pi)$ kitimui, užtvarinès juostos plotis ties $\theta=\pi$ taip pat didèja (3.11 pav. a ir $b, 3$ kreivès).

3.12 paveiksle (a) ir (b) pateiktos charakteristikos iliustruoja asimetrinių netolygumų įtaką meandrinès lètinimo sistemos savybèms. 2-osios kreivès gautos, kai skiriasi meandrinès sistemos periferinių sričių banginès varžos. 3-osios kreivès gautos, kai centrinè meandro elektrodo dalis pasislinkusi i vieną iš kraštų, t. y. periferinès sritys yra skirtingų ilgių. Lyginant 2-ujų ir 3-ujų kreivių charakteristikas su 1-uјų kreivių charakteristikomis, kai sistema neturi skersinio asimetriškumo, matyti, kad skersinis asimetriškumas stipriai pakeičia meandrinès lètinimo sistemos dažnines savybes.

Esant skersiniam asimetriškumui, iejjimo varža labai greitai kinta kai fazès kampas $\theta$ pasiekia $\pi / 2$. Tuomet užtvarinè juosta atsiranda ties dvigubai žemesniais dažniais

$$
f_{\mathrm{c}}(\pi / 2)=\frac{1}{4 t_{\mathrm{v}}} .
$$

Remiantis (Štaras et al. 2010) galima teigti, kad ịvyko toks didelis meandrinès sistemos dažninių savybių kitimas, nes esant skersiniam asimetriškumui netolygumų periodas išilgai meandro laidininko tapo du kartus didesnis lyginant su netolygumų periodu, kai skersinio asimetriškumo nèra.

Meandrinès lètinimo sistemos dažninès charakteristikos, esant skersiniam asimetriškumui, yra panašios ị gautas, kai skiriasi meandrinès sistemos gretimų laidininkų pločiai. Esant skirtingiems meandrinio elektrodo gretimų laidininkų pločiams netolygumų periodas išilgai meandro laidininko taip pat du kartus ilgesnis nei meandro juostelès ilgis. Tokiu atveju dažninių charakteristikų netolygumai ir užtvarinè juosta atsiranda ties $\theta=\pi / 2$.

3.13 paveiksluose (a) ir (b) pateiktos dažninès lètinimo koeficiento ir įejjimo varžos charakteristikos, kai meandrinès lètinimo sistemos netolygumų periodą sudaro dvi vienalytès sritys. Jos iliustruoja banginių varžų $Z_{i}(0)$ ir $Z_{i}(\pi)$ asimetrijos įtaką meandrinès lètinimo sistemos savybèms.

Kai banginès varžos išilgai meandro elektrodo nekinta, meandrinès sistemos dažninès charakteristikos yra tolygios (3.13 pav. a ir b). Kai $Z(0)$ ir $Z(\pi)$ kinta išilgai meandro elektrodo, užtvarinè juosta atsiranda, kai fazès kampas $\theta$ artejja prie $\pi / 2$ (3.13 pav. a ir b, 2-4 kreivès). Didejjant banginių varžų $Z(0)$ ir $Z(\pi)$ svyravimams, užtvarinès juostos plotis taipogi dideja (3.13 pav. a ir b, 2-4 kreivès). Pavyzdžiui, vienos iš vienalyčių sričių banginiai varžai esant nelyginiam sužadinimui sumažejus $10 \Omega$, pakitus bendram vienalyčių sričių banginių varžų santykiui, užtvarinè juosta išaugo tris kartus nuo $0,5 \mathrm{GHz}$ iki $1,5 \mathrm{GHz}$.

Taigi, esant skersiniam asimetriškumui, iejjimo varža labai greitai kinta, kai fazès kampas $\theta$ pasiekia nebe $\pi$ o $\pi / 2$, ir užtvarinè juosta atsiranda ties dvigubai mažesniais dažniais. 


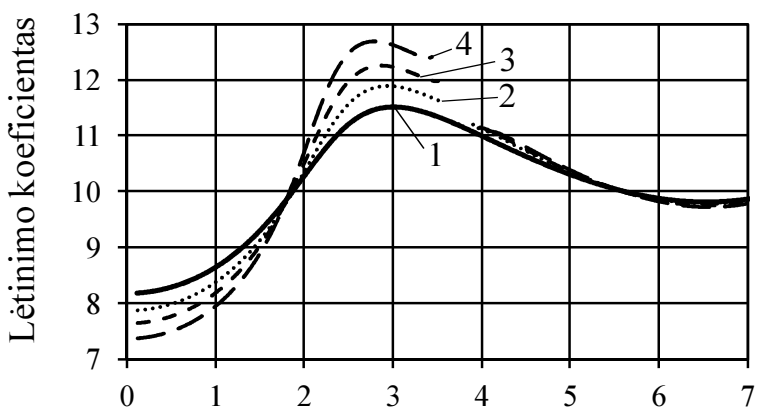

(a)

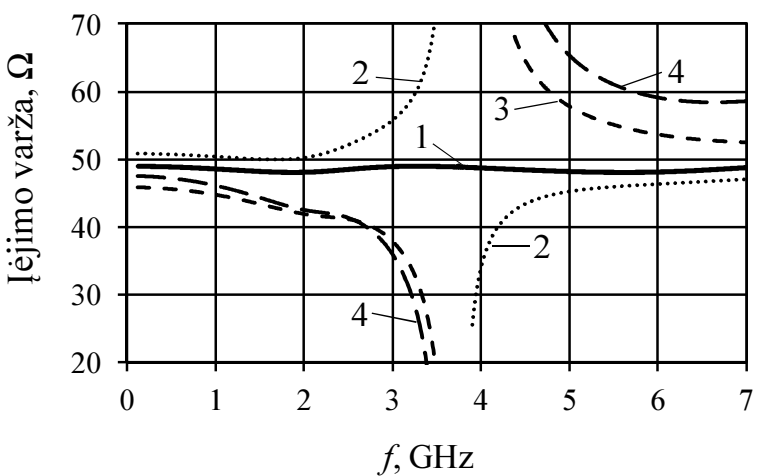

(b)

3.13 pav. Nevienalytès meandrinès lètinimo sistemos lètinimo koeficiento (a) ir ịjimo varžos (b) priklausomybé nuo dažnio, kai netolygumų periodą sudaro dvi vienalytės sritys, kai $x_{2}=l_{1}+l_{2}=20 \mathrm{~mm}, l_{1}=l_{2}=10 \mathrm{~mm}, L=2 \mathrm{~mm}$ ir:

$$
\begin{array}{ll}
1-Z_{1}(0) / Z_{1}(\pi)=60 / 40 \Omega, & Z_{2}(0) / Z_{2}(\pi)=60 / 40 \Omega ; \\
2-Z_{1}(0) / Z_{1}(\pi)=60 / 40 \Omega, & Z_{2}(0) / Z_{2}(\pi)=70 / 40 \Omega ; \\
3-Z_{1}(0) / Z_{1}(\pi)=60 / 30 \Omega, & Z_{2}(0) / Z_{2}(\pi)=60 / 40 \Omega ; \\
4-Z_{1}(0) / Z_{1}(\pi)=60 / 30 \Omega, & Z_{2}(0) / Z_{2}(\pi)=70 / 40 \Omega
\end{array}
$$

Fig. 3.13. Retardation factor (a) and input impedance (b) versus frequency of the inhomogeneous meander slow-wave system then inhomogeneous period consist of to homogeneous sections and at $x_{2}=l_{1}+l_{2}=20 \mathrm{~mm}, l_{1}=l_{2}=10 \mathrm{~mm}, L=2 \mathrm{~mm}$ and:

$$
\begin{array}{ll}
1-Z_{1}(0) / Z_{1}(\pi)=60 / 40 \Omega, & Z_{2}(0) / Z_{2}(\pi)=60 / 40 \Omega ; \\
2-Z_{1}(0) / Z_{1}(\pi)=60 / 40 \Omega, & Z_{2}(0) / Z_{2}(\pi)=70 / 40 \Omega ; \\
3-Z_{1}(0) / Z_{1}(\pi)=60 / 30 \Omega, & Z_{2}(0) / Z_{2}(\pi)=60 / 40 \Omega ; \\
4-Z_{1}(0) / Z_{1}(\pi)=60 / 30 \Omega, & Z_{2}(0) / Z_{2}(\pi)=70 / 40 \Omega
\end{array}
$$

Taip yra todèl, kad esant skersiniam asimetriškumui netolygumų periodas išilgai meandro laidininko tampa du kartus didesnis lyginant su netolygumų periodu, kai skersinio asimetriškumo nèra. Skersinis lètinimo sistemos meandrinio laidininko asimetriškumas yra vengtinas bruožas. 


\subsection{Hibridinès konstrukcijos lètinimo sistemos modelis ir savybių analizè}

Siekiant pagerinti MLS savybes, keičiamos jos meandrinio laidininko periferinės sritys. Šiame poskyryje sudaromas hibridinès letinimo sistemos (HLS) modelis su meandro formos centrine dalimi ir spiralès formos periferinèmis sritimis.

\subsubsection{Hibridinès konstrukcijos lëtinimo sistemos modelis}

Siekiant pagerinti MLS savybes, modifikuojamos periferinès meandrinio laidininko sritys. Kilpu pavidalo meandro periferinès dalys pakeičiamos spiralès formos periferinemis sritimis. Tokiu atveju gaunama HLS su meandro formos centrine dalimi ir spiralès formos periferinèmis sritimis (3.14 pav.).

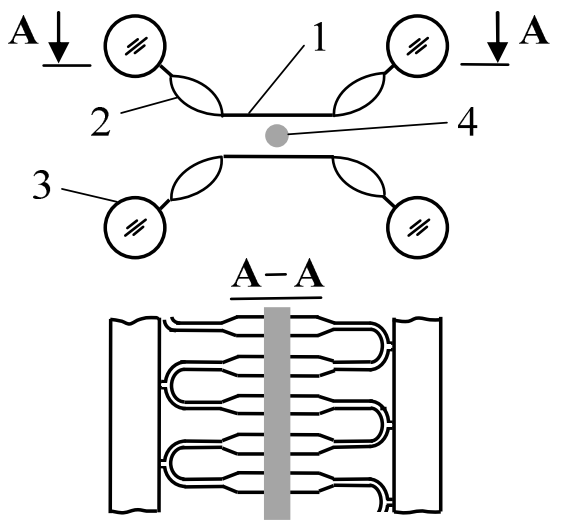

3.14 pav. Hibridinès sistemos skersinis pjūvis (a) ir vaizdas iš viršaus (b):

1 - centrinis daugialaidès linijos elektrodas; 2 - spiralès formos periferinès elektrodo sritys; 3 - dielektriniai laikikliai; 4 - elektronų spindulys

Fig. 3.14. The cross-section (a) and the top view (b) of the hybrid Helixl-Meander-Helix line: 1 - central part; 2 - formed peripheral parts; 3 -dielectric holder; 4 - electron beam

HLS analizei naudosime daugialaidžių linijų metodą. Tokios sistemos modelis pavaizduotas 3.15 paveiksle. Daugialaides linijos atkarpa sudaryta iš vienos eilès laidininkų. Meandrinị laidininką sudaro lygiagrečiai esančių centrinių laidininkų rinkinys ir indukciniai elementai, modeliuojantys spiralès formos sujungimus tarp centrinių dalių.

Atsižvelgiant, kad laidininkai yra vakuume, naudojant kvazi-TEM bangu aproksimacijas ir teigiant, kad meandras turi turèti dvi vienalytes sritis viename periode, galime išvesti daugialaidès linijos laidininko įtampos ir srovès išraiškas. 


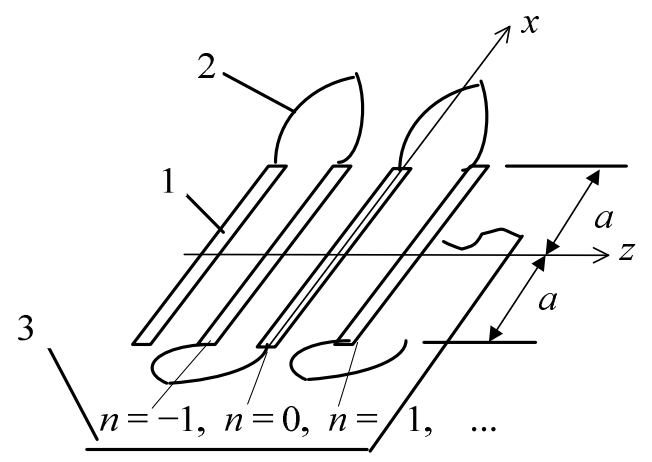

3.15 pav. Hibridinès sistemos modelis: 1 - daugialaidès linijos centriniai laidininkai, modeliuojantys centrinę sistemos dalị; 2 - kraštinių laidininkų kilpos; 3 - ekranas

Fig. 3.15. The model of the asymmetrical hybrid system: 1 - central conductor of the multiconductor line; 2 - turn of conductor in the peripheral part; 3 - shield

$$
\begin{gathered}
\underline{U}_{n}(x)=\left(\underline{A}_{1} \sin k x+\underline{A}_{2} \cos k x\right) \mathrm{e}^{-\mathrm{j} n \theta}+ \\
\left(\underline{A}_{3} \sin k x+\underline{A}_{4} \cos k x\right) \mathrm{e}^{-\mathrm{j} n(\theta+\pi),} \\
\underline{I}_{n}(x)=\mathrm{j} Y(\theta)\left(\underline{A}_{1} \cos k x-\underline{A}_{2} \sin k x\right) \mathrm{e}^{-\mathrm{j} n \theta}+ \\
\mathrm{j} Y(\theta+\pi)\left(\underline{A}_{3} \cos k x-\underline{A}_{4} \sin k x\right) \mathrm{e}^{-\mathrm{j} n(\theta+\pi),}
\end{gathered}
$$

čia $\underline{A}_{i}$ - amplitudiniai koeficientai, $n$ - laidininko numeris; $k=\omega / \mathrm{c}_{0}-$ bangos skaičius; $\omega$ - kampinis greitis; $\theta$ - fazès kampas tarp gretimų laidininkų itampų ar srovių; $Y(\theta)$ ir $Y(\theta+\pi)$ - banginiai daugialaidès linijos laidžiai.

Bangai sklindant $z$ kryptimi, įtampos ir srovès turi atitikti kraštines sąlygas:

$$
\begin{gathered}
\underline{U}_{1}(0)=\underline{U}_{0}(0), \\
\underline{I}_{1}(0)=-\underline{I}_{0}(0), \\
\underline{U}_{0}(a)=\underline{U}_{1}(a)+\mathrm{j} \omega L_{\mathrm{H}} \underline{I}_{0}(a), \\
\underline{I}_{0}(a)=-\underline{I}_{1}(a) .
\end{gathered}
$$

čia $L_{\mathrm{H}}$ - periferinių sričių induktyvumas.

Irašę (3.40) ir (3.41) įtampų ir srovių išraiškas ị kraštinių sąlygų formules (3.42)-(3.45) gauname algebrinių lygčių sistemą. Prilyginę $\underline{A}_{i}$ koeficientų matricos determinantą nuliui arba spręsdami dispersinę lygti gauname lètinimo koeficiento $k_{L}$ ir dažnio $f$ išraiškas 


$$
\begin{gathered}
k_{\mathrm{L}}=\mathrm{c}_{0} / v_{f}=\theta / k L, \\
f=k \mathrm{c}_{0} / 2 \pi,
\end{gathered}
$$

čia $v_{\mathrm{f}}$ - bègančiosios bangos fazinis greitis.

Meandrinès sistemos $\underline{Z}_{\text {IN }}$ priklauso nuo koordinatès $x$. Kai $x=0$ :

$$
\underline{Z}_{\mathrm{IN}}(0)=\frac{\underline{U}_{0}(0)}{\underline{I}_{0}(0)}=\frac{1}{\mathrm{j} Y(\theta)} \cdot \frac{\left(1-\mathrm{e}^{-\mathrm{j} \theta}\right) \cos k a}{\left(1-\mathrm{e}^{-\mathrm{j} \theta}\right) \sin k a} .
$$

\subsubsection{Hibridinès konstrukcijos lètinimo sistemos savybių analizè}

HLS dažninès lètinimo koeficiento ir ịejimo varžos charakteristikos, apskaičiuotos remiantis daugialaidžių linijų metodu, pateiktos 3.16 paveiksle.

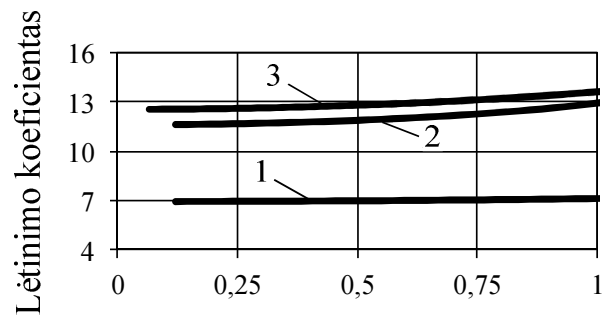

(a)

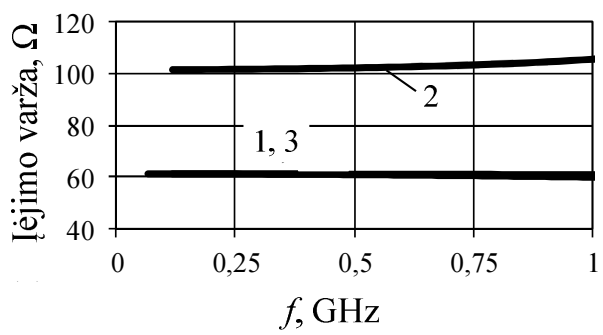

(b)

3.16 pav. Hibridinès sistemos lètinimo koeficiento (a) ir ịejimo varžos (b) priklausomybè nuo dažnio, kai $L=2 \mathrm{~mm}$, laidininkų storis $0,2 \mathrm{~mm}$, tarpai tarp laidininkų centrinëje dalyje $0,5 \mathrm{~mm}$, atstumai iki ekranų 0,5 ir $10 \mathrm{~mm}$, banginės varžos $\mathrm{Z}(0)=87,7 \Omega, \mathrm{Z}(\pi)=42,6 \Omega$, bei: $1-\mathrm{a}=10 \mathrm{~mm}, \mathrm{~L}_{\mathrm{H}}=0 \mathrm{nH} ; 2-\mathrm{a}=10 \mathrm{~mm}$, $\mathrm{L}_{\text {ind }}=5 \mathrm{nH} ; 3-\mathrm{a}=18 \mathrm{~mm}, \mathrm{~L}_{\mathrm{H}}=0 \mathrm{nH}$

Fig. 3.16. Retardation factor (a) and input impedance (b) of the hybrid system versus frequency at $L=2 \mathrm{~mm}$, thickness of conductors $0.2 \mathrm{~mm}$, gaps between them in the central part $0.5 \mathrm{~mm}$, shield distances 0.5 and $10 \mathrm{~mm}$, characteristic impedances $\mathrm{Z}(0)=87.7 \Omega, \mathrm{Z}(\pi)=42.6 \Omega$ and: $1-\mathrm{a}=10 \mathrm{~mm}, \mathrm{~L}_{\mathrm{H}}=0 \mathrm{nH} ; 2-\mathrm{a}=10 \mathrm{~mm}$, $\mathrm{L}_{\text {ind }}=5 \mathrm{nH} ; 3-\mathrm{a}=18 \mathrm{~mm}, \mathrm{~L}_{\mathrm{H}}=0 \mathrm{nH}$ 
Iš rezultatų matyti, kad taikant HLS galima ženkliai padidinti lètinimo koeficiento ir iejjimo varžos vertes. Be to lètinimo koeficientas ir iejjimo varža mažai kinta plačiame dažnių ruože. Taip pat svarbu paminèti, kad paprastos meandrinès ar spiralinès sistemos banginè varža mažèja didejant dažniui (Štaras et al. 2010). Hibridinès sistemos banginè varža didejjant dažniui lètai didejja (3.16 pav. b, 2 kreivè). Ši savybè gali būti panaudota bėgančiosios bangos kreipimo sistemose kompensuoti dažninius amplitudès iškraipymus (Štaras et al. 2012).

\subsection{Lètinimo sistemų tyrimas taikant specializuotą programinę įrangą}

Šiame poskyryje nevienalytės LS tiriamos, taikant specializuotą programinę ịrangą. Spiralinès ir hibridinès konstrukcijos LS tiriamos taikant programų paketą CST Microwave Studio ${ }^{\circledR}$, kuriame skaičiavimai vykdomi skaitiniu baigtinių skirtumų laiko srities metodu. Meandrinès konstrukcijos LS tiriamos, taikant programų paketą Sonnet ${ }^{\circledR}$, kuriame skaičiavimai vykdomi skaitiniu momentų metodu.

\subsubsection{Nevienalyčių lètinimo sistemų tyrimo modeliai}

Skaičiuojant spiralinių, meandrinių ir hibridinių LS dažnines amplitudès $(\mathrm{DACh})$ ir fazès $(\mathrm{DFCh})$ charakteristikas CST Microwave Studio ${ }^{\circledR}$ ir Sonnet ${ }^{\circledR}$ programu paketų terpeje, taikoma 3.17 paveiksle pateikta LS jungimo ị signalų kanalą schema.

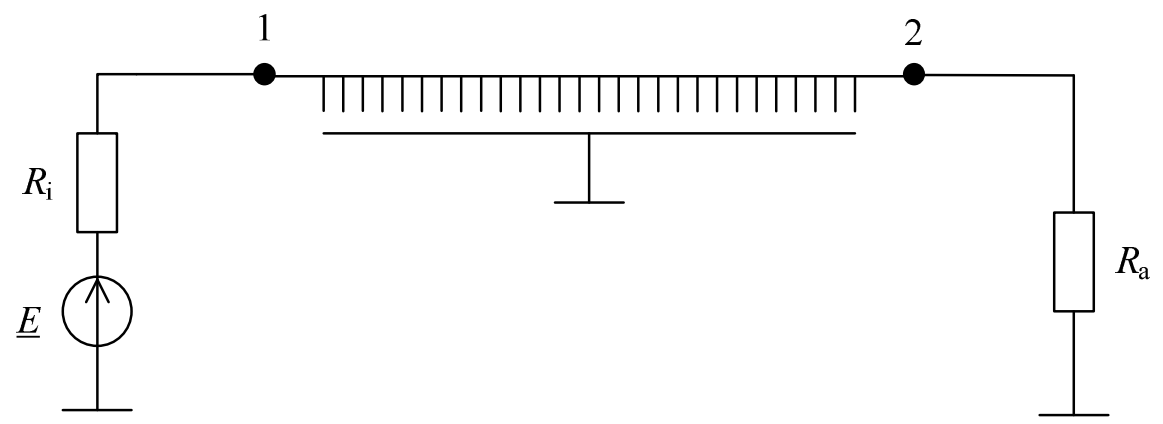

3.17 pav. Lètinimo sistemų, turinčiu periodinių netolygumų, ijungtụ ị signalų kanalą, principinè elektrinè schema

Fig. 3.17. The principal electric scheme of a slow-wave system with periodic inhomogeneities, plugged into signal channel 
Skaičiuojant priimta, kad signalo šaltinio $\underline{E}$ vidaus varža $R_{\mathrm{i}}$ ir apkrovos varža $R_{\mathrm{a}}$ yra lygios tiriamosios spiralinès sistemos banginei varžai $Z_{B}$ žemujjų dažnių srityje. Ieškant lètinimo sistemos iejjimo varžos verčių keičiamos signalų šaltinio ir generatoriaus varžos tol, kol gaunami minimalūs atspindžiai nuo lètinimo sistemos iejjimo.

Modeliuojant spiralinès konstrukcijos lètinimo sistemą (3.18 pav.) spiralinis laidininkas talpinamas ị išorinį ekraną, kuris nuo spiralès kraštų visomis krytimis nutolęs vienodais atstumais $c_{1}=c_{2}=1 \mathrm{~mm}$. Sritis tarp spiralès ir išorinio ekrano užpildoma dielektriku, kurio santykinè dielektrinè skvarba $\varepsilon_{\mathrm{r}}=1$. Spiralès ilgis $L_{\mathrm{S}}=15 \mathrm{~mm}$, spiralinio laidininko matmenys $h=8 \mathrm{~mm}$ ir $b=3 \mathrm{~mm}$, spiralès Žingsnis $L=1 \mathrm{~mm}$.

Žinoma, kad lètinimo sistemų prievaduose dèl elektrinio lauko sklaidos susidaro dažniausiai talpinio pobūdžio reaktyvumai. Atsižvelgiant i (Štaras et al. 2010) spiralès galų reaktyvumo įtaką sumažinta siaurinant kraštinių vijų laidininkus.

Tyrimu metu buvo tikrinta, kaip išilgai spiralès vijos kintantis periodinis nevienalytiškumas, kintant vienalyčių sričių banginėms varžoms arba vienalyčių sričių ilgių santykiams, itakoja spiralinès lètinimo sistemos užtvarines savybes.

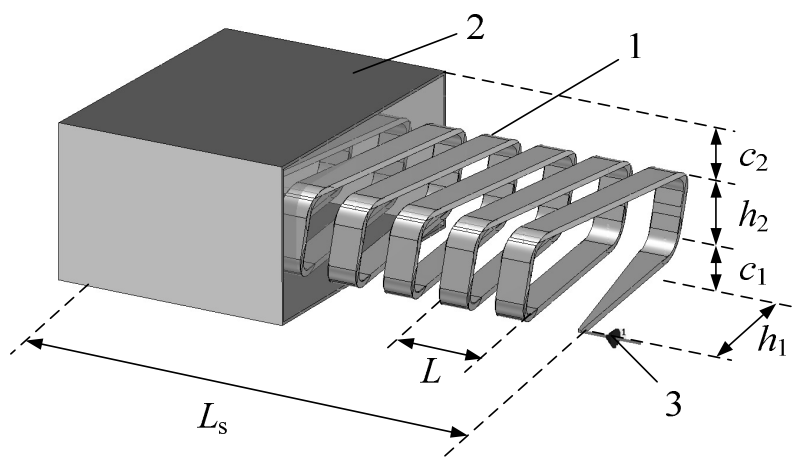

3.18 pav. Spiralinès lètinimo sistemos modelis CST Microwave Studio ${ }^{\circledR}$ terpèje:

1 -spiralè; 2 -išorinis ekranas; 3 - ịvesties prievadas

Fig. 3.18. The model of helical slow-wave system in CST Microwave Studio ${ }^{\circledR}$ : 1 - helix; 2 - external shield; 3 - input port

Spiralinès lètinimo sistemos banginę varžą lemia spiralès vijos laidininko plotis ir storis, atstumas tarp gretimų laidininkų ir atstumas nuo spiralès iki išorinio ekrano (3.19 pav.).

Žinoma, kad vèlinimo trukmès dažninę charakteristiką galima apskaičiuoti iš fazès skirtumą tarp sistemos įèjimo ir išèjimo nurodančio $S_{21}$ parametro: 


$$
t_{\mathrm{v}}=\frac{S_{21}}{360 \cdot f},
$$

čia $f$ - dažnis Hz; $S_{21}$ - fazès skirtumo kampas laipsniais tarp sistemos įejjimo ir išèjimo signalo.

Sistemos lètinimo koeficientas apskaičiuojamas pagal išraišką:

$$
k_{\mathrm{L}}=\frac{\mathrm{c}_{0} \cdot t_{\mathrm{v}}}{L_{\mathrm{s}}},
$$

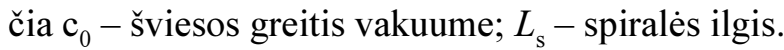

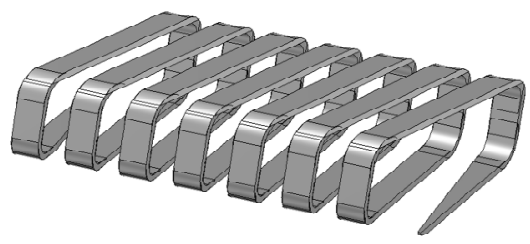

(a)

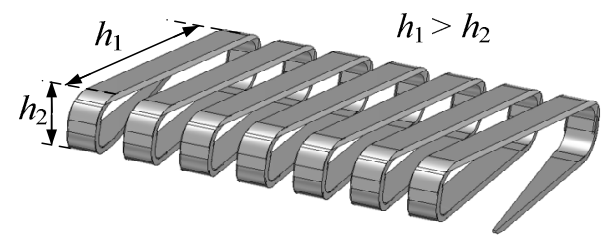

(c)

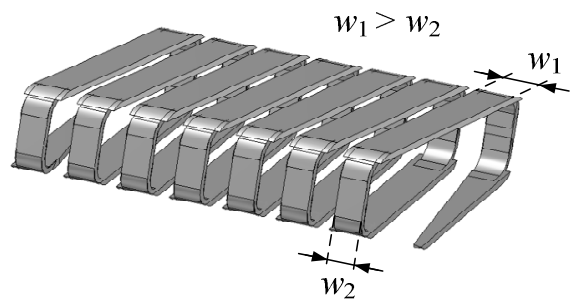

(b)

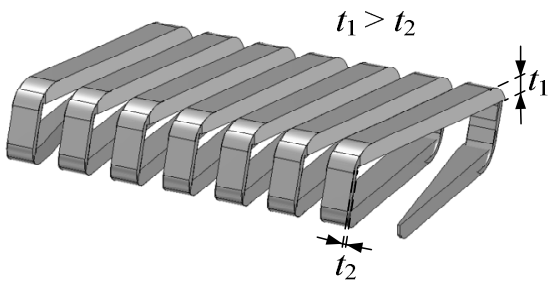

(d)

3.19 pav. Pradinis (a), platesnès vienos iš vienalyčių sričių (b), vienos iš vienalyčių sričių sumažinto ilgio (c) ir storesnès vienos iš vienalyčių sričių (d) lètinimo sistemos spiralinis laidininkas CST Microwave Studio ${ }^{\circledR}$ terpeje

Fig. 3.19. Default (a), with wider homogeneous sections (b), with shorter homogeneous sections (c) and with thicker homogeneous sections (d) conductor of helical slow-wave system in CST Microwave Studio ${ }^{\circledR}$

Sistemos įejjimo varžą galima rasti keičiant signalo šaltinio ir generatoriaus varžas $\left(R_{\mathrm{i}}=R_{\mathrm{a}}\right)$ tol, kol gaunami mažiausi atspindžiai. Sistemos iejjimo varžą taip pat galima rasti iš $S_{11}$ parametrų išraiškų:

$$
Z_{\mathrm{IN}}=Z_{\mathrm{a}}\left(\frac{1+\underline{S}_{11}}{1-\underline{S}_{11}}\right) \text {. }
$$




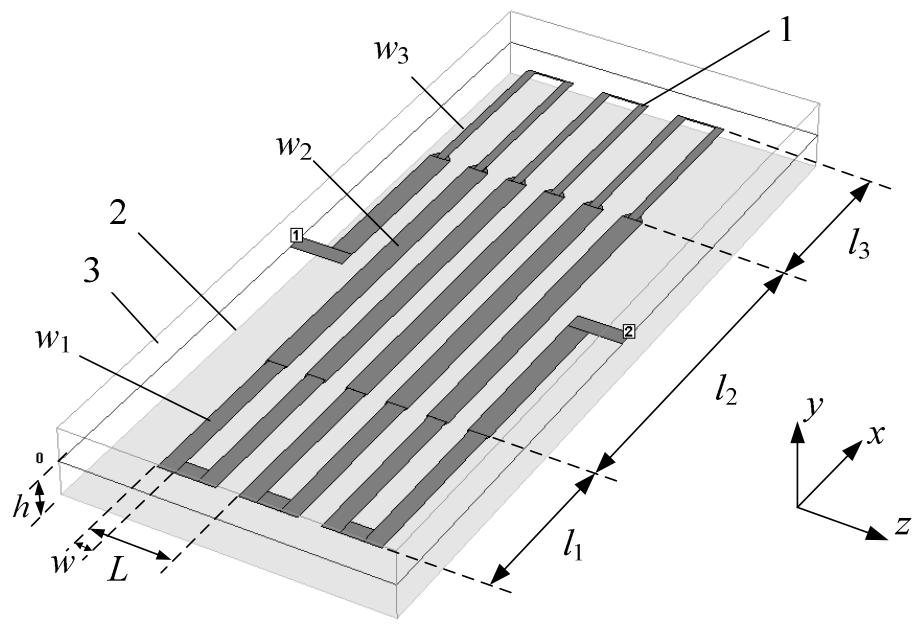

3.20 pav. Meandrinès lètinimo sistemos trimatis modelis Sonnet ${ }^{\circledR}$ terpejje, pasižymintis skersiniu asimetriškumu: 1 - meandro formos laidininkas; $2-h$ storio dielektrinis pagrindas; 3 - oro sluoksnis

Fig. 3.20. 3D model of meander slow-wave system with asymmetrical meander electrode in Sonnet ${ }^{\circledR}: 1$ - meander shape conductor; 2 - dielectric substrate of thickness $h ; 3$ - layer of air

Meandrinès lètinimo sistemos, turinčios periodinių netolygimų, tiriamos momentų metodu, taikant Sonnet ${ }^{\mathbb{B}}$ programų paketą. Nagrinejjamos meandrinès lètinimo sistemos, pasižyminčios skersiniu asimetriškumu. Skersinis asimetriškumas atsiranda tuomet, kai sistema yra nesimetriška per centrinę laidininko dalị einančios statmenos plokštumos $y 0 z$ atžvilgiu. Skersinis asimetriškumas modeliuojamas, parenkant skirtingus kraštinių sričių storius bei stumdant centrinę meandro sritị link vieno iš kraštų.

Meandrinès lètinimo sistemos vienas iš modeliu pateiktas 3.20 paveiksle. Lètinimo sistemą sudaro 7 lygiagrečiai išdèstyti laidininkai, sujungti meandro forma. Šiuo atveju modeliuojamas lètinimo sistemos meandrinio laidininko skersinis asimetriškumas, parenkant skirtingus kraštinių sričių, kurių ilgiai $l_{1}$ ir $l_{3}$, laidininkų pločius $w_{1}$ ir $w_{3}$. Meandrinis laidininkas patalpintas ant dielektrinio pagrindo, kurio storis $h$ ir santykiné dielektrinè svarba $\varepsilon_{\mathrm{r}}=7,3$. Viršutinị sluoksnị sudaro oras $\left(\varepsilon_{\mathrm{r}}=1\right)$. Tyrimų metu naudotas idealus laidininkas be nuostolių.

Siekiant patikrinti hibridinès lètinimo sistemos skaičiavimo rezultatus, gautus daugialaidžių linijų metodu, naudota CST Microwave Studio ${ }^{\circledR}$ programų paketas. Hibridinès lètinimo sistemos modelis pateiktas 3.21 paveiksle (Daškevičius et al. 2010). 


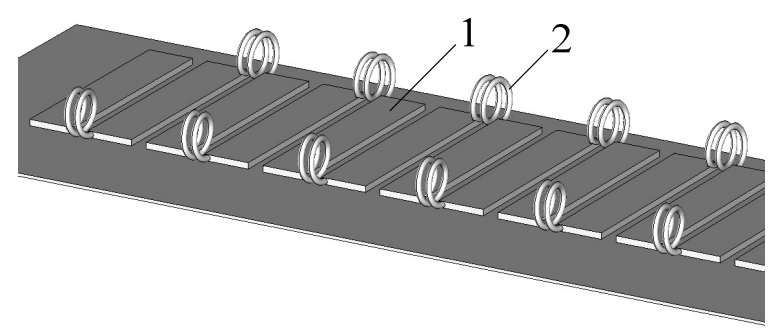

3.21 pav. Hibridinès sistemos modelis, su spiralès formos kraštinėmis sritimis (Daškevičius et al. 2010): 1 - meandro laidininkas; 2 - spiralès formos kraštinès sritys Fig. 3.21. The model of the system with coils connecting conductors to form the hybrid HMH system (Daškevičius et al. 2010): 1 - meander electrode; 2 - turn of connecting conductors

Meandrinį laidininką sudaro lygiagrečių centrinių laidininkų rinkinys ir indukciniai elementai, modeliuojantys spiralès formos sujungimus tarp centrinių dalių.

\subsubsection{Nevienalyčių lètinimo sistemų tyrimo rezultatai}

Spiralinių lètinimo sistemų periodiniai netolygumai tirti dviem atvejais: kintant vienalyčių sričių banginių varžų santykiui ir kintant vienalyčiu sričių ilgių santykiui. 3.22 paveiksle pateiktos SLS (3.18 pav.) dažninès amplitudès ir lètinimo koeficiento charakteristikos, kai kinta sistemos vienalyčių sričių banginių varžu santykis. Vienalyčių sričių banginių varžų santykiai buvo parinkti $Z_{\mathrm{B} 1} / Z_{\mathrm{B} 2}=1,2$; 1,$5 ; 2$. Skirtingos vienalyčių sričių banginès varžos parinktos, keičiant laidininkų storius ir pločius (3.19 pav. b ir d).

Iš rezultatų matyti, kad didejjant SLS vienalyčių sričių banginių varžų santykiui atsiranda užtvariné juosta (3.22 pav. a). Platėjant sistemos užtvarinei juostai, siaurejja praleidžiamụjų dažnių juosta. Kai vienalyčių sričių banginių varžų santykis neviršija 1,2 karto, pralaidumo juostos riba yra ties $f_{\mathrm{r} 1} \approx 7 \mathrm{GHz}$. Vienalyčių sričių banginių varžų santykiui padidejjus iki 2 kartu pralaidumo juosta susiaurèja iki $f_{\mathrm{r} 3} \approx 6 \mathrm{GHz}$, t. y. beveik $15 \%$.

Didèjantis spiralinès lètinimo sistemos periodinis nevienalytiškumas įtakojo lètinimo koeficiento dispersijos didejjimą (3.22 pav. b). Iki $1 \mathrm{GHz}$ dažnio lètinimo koeficiento charakteristikas labai įtakoja išorinis ekranas, dẻl kurio lètinimo koeficientas yra didesnis. Taip pat iš dažninès amplitudès ir lètinimo koeficiento charakteristikų matyti, kad aukštesniujų dažnių ruože virš $1 \mathrm{GHz}$ signalų kanale su spiraline lètinimo sistema (3.18 pav.) pasireiškia atspindžiai, sukeliantys rezonansinius reiškinius. Atspindžių priežastis yra aukštuose dažniuose sumažejusi spiralinès lètinimo sistemos banginè varža. 


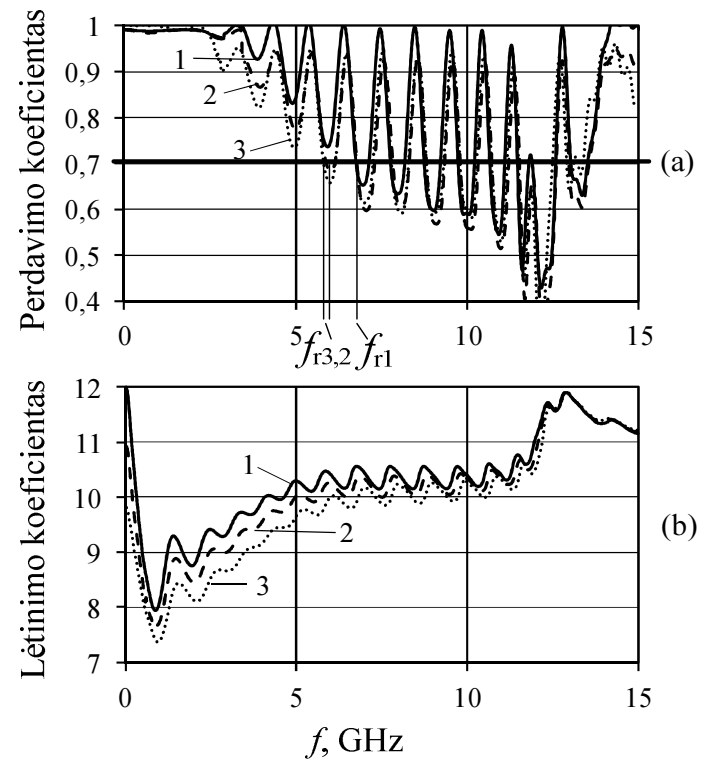

3.22 pav. Spiralinès lètinimo sistemos dažninès amplitudès (a) ir lètinimo koeficiento (b) charakteristikos, kai $R_{\mathrm{a}}=R_{\mathrm{i}}=130 \Omega, n=7$ ir: $1-Z_{\mathrm{B} 1} / Z_{\mathrm{B} 2}=1,2 ; 2-Z_{\mathrm{B} 1} / Z_{\mathrm{B} 2}=1,5$;

$$
3-Z_{\mathrm{B} 1} / Z_{\mathrm{B} 2}=2
$$

Fig. 3.22. Amplitude-frequency responses (a) and retardation factor (b) characteristics of the helical slow-wave systems at $R_{\mathrm{a}}=R_{\mathrm{i}}=130 \Omega, n=7$ and: $1-Z_{\mathrm{B} 1} / Z_{\mathrm{B} 2}=1.2$;

$$
2-Z_{\mathrm{B} 1} / Z_{\mathrm{B} 2}=1.5 ; 3-Z_{\mathrm{B} 1} / Z_{\mathrm{B} 2}=2
$$

Tolesni SLS tyrimai parodè, kad dažniai, ties kuriais atsiranda užtvarinè juosta, priklauso ir nuo spiralių vijų vienalyčių dalių ilgio. Praplèsti pralaidumo juostą galima trumpinant trumpesnę vienalytę sriti (3.19 pav. c).

MLS skersinio asimetriškumo tyrimai atlikti, keičiant kraštinių sričių banginių varžų santykị arba stumdant centrinę meandrinio laidininko dalị link vieno iš kraštų (3.20 pav.). 3.23 paveiksle pateikti rezultatai meandrinès lètinimo sistemos, pasižyminčios skersiniu asimetriškumu. Kraštinių sričių banginės varžos derinamos, keičiant kraštinių sričių meandrinio laidininko pločius.

Kai kraštinių sričių banginių varžų santykis neviršija 1,5 karto, užtvarinè juosta prasideda ties 2,6 GHz dažniu (3.23 pav. a, 1 kreivè). Didèjant meandro kraštinių sričių banginių varžų santykiui pralaidumo juosta siaureja. Kai banginių varžų santykis pasiekia 2,5 karto užtvarine juosta prasideda ties $1,2 \mathrm{GHz}$ (3.23 pav. a, 3 kreivè). MLS iejjimo varža labai kinta ir susiformuoja užtvarinè juosta, kai fazès kampas $\theta$ tarp gretimų laidininkų įtampų ir srovių pasiekia $\pi$, o 
dažnis pasiekia $f_{\mathrm{c}}(\pi)=1 / 2 t_{\mathrm{v}}(3.23$ pav. c). Taip pat ties užtvarine juosta padideja lètinimo koeficiento kitimas (3.23 pav. b).

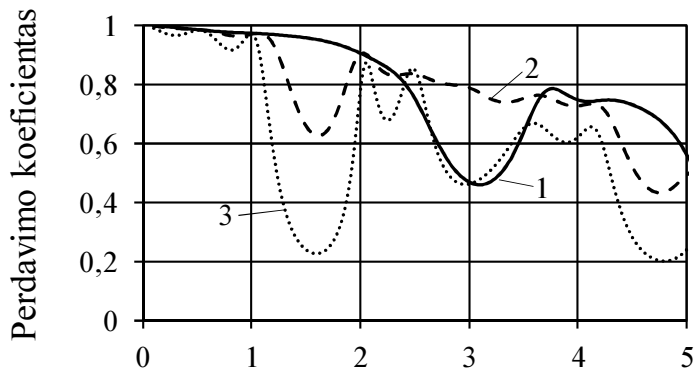

(a)

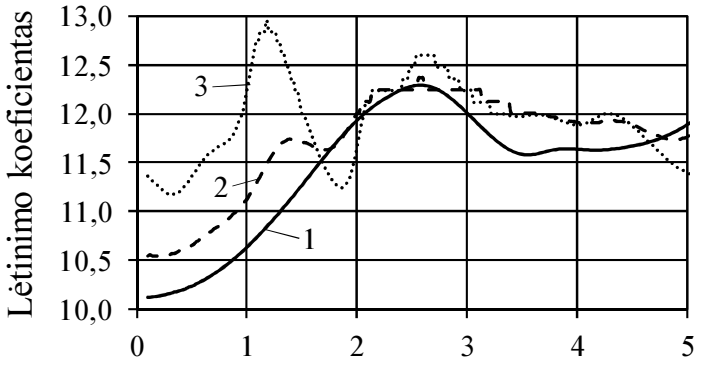

(b)

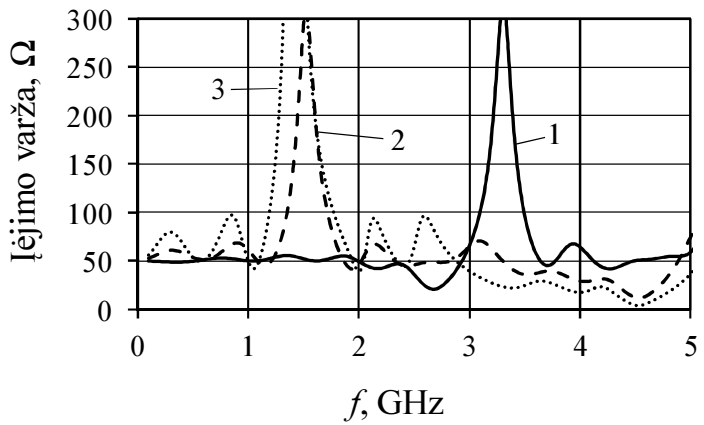

(c)

3.23 pav. Meandrinès lètinimo sistemos dažninès amplitudès (a), lètinimo koeficiento (b) ir ịejjimo varžos (c) charakteristikos, kai $R_{\mathrm{a}}=R_{\mathrm{i}}=55 \Omega, n=7$ ir: $1-Z_{\mathrm{B} 1} / Z_{\mathrm{B} 2}=1,5$;

$$
2-Z_{\mathrm{B} 1} / Z_{\mathrm{B} 2}=2 ; 3-Z_{\mathrm{B} 1} / Z_{\mathrm{B} 2}=2,5
$$

Fig. 3.23. Amplitude-frequency responses (a), retardation factor (b) and input impedance (c) characteristics of the meander slow-wave system at $R_{\mathrm{a}}=R_{\mathrm{i}}=55 \Omega$,

$$
n=7 \text { and: } 1-Z_{\mathrm{B} 1} / Z_{\mathrm{B} 2}=1.5 ; 2-Z_{\mathrm{B} 1} / Z_{\mathrm{B} 2}=2 ; 3-Z_{\mathrm{B} 1} / Z_{\mathrm{B} 2}=2.5
$$

Didinant meandrinès lètinimo sistemos nevienalyčių periodų skaičių užtvarinès sistemos savybès ryškèja. Padidinus nevienalyčių periodų skaičių nuo 3 
(3.24 pav. a, 1 kreivè) iki 6 (3.24 pav. a, 2 kreivè) pralaidumo juosta susiaurejo nuo 2,6 GHz iki 2,3 GHz.

Meandrinès lètinimo sistemos modelis buvo tikrintas eksperimentiškai. Tyrimų schema pateikta A priede. Tyrimo rezultatai pateikti B priede. Sistema buvo tirta dažnių ruože iki $1,2 \mathrm{GHz}$. Gautos dažninès amplitudès charakteristikos šiame dažnių ruože kokybiškai atkartojo modeliavimo metu gautus rezultatus.

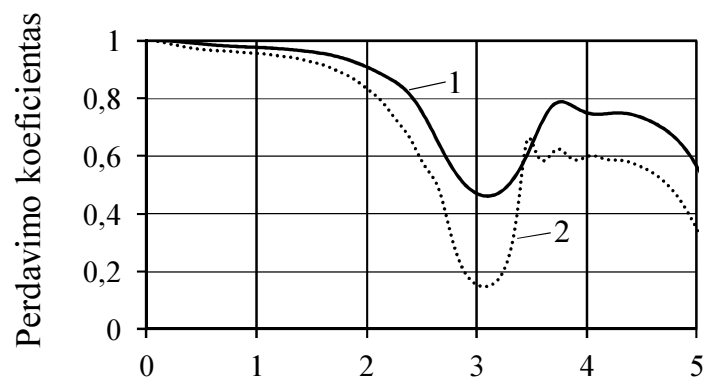

(a)

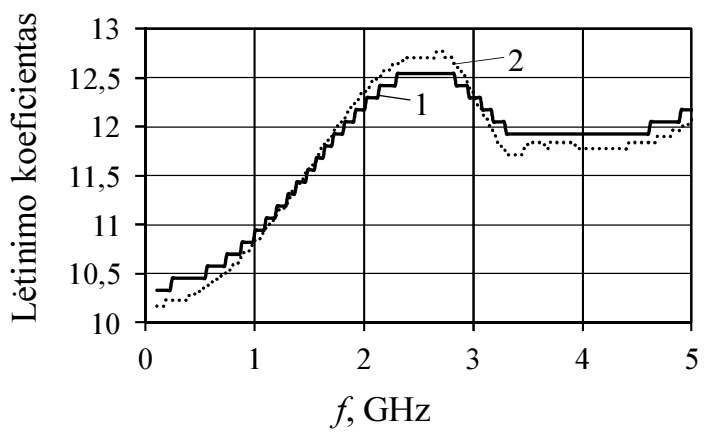

(b)

3.24 pav. Meandrinès lètinimo sistemos perdavimo (a) ir lètinimo (b) koeficientu charakteristikos, kai $R_{\mathrm{a}}=R_{\mathrm{i}}=55 \Omega, Z_{\mathrm{B} 1} / Z_{\mathrm{B} 2}=1,5$ ir: $1-n=3 ; 2-n=6$

Fig. 3.24. Transfer coefficient (a) and retardation factor (b) of the meander slow-wave systems at $R_{\mathrm{a}}=R_{\mathrm{i}}=55 \Omega, Z_{\mathrm{B} 1} / Z_{\mathrm{B} 2}=1.5$ and: $1-n=3 ; 2-n=6$

Daugialaidžių linijų metodu trečiame poskyryje buvo nustatyta, kad taikant hibridinę sistemą (3.21 pav.) galima padidinti sistemos banginę varžą, lyginant su meandrinès sistemos varža. Daugialaidžių linijų metodu kraštinès MLS sritys buvo nagrinejjamos tarsi induktyviniai elementai - ritès. Nebuvo atsižvelgta i sujungimus tarp kraštinių meandro sričių ir centrinès srities.

HLS rezultatai lyginami su MLS rezultatais (3.25 pav.). Pagrindiniai MLS parametrai: meandrinio laidininko plotis $2 a=15 \mathrm{~mm}$, žingsnis tarp gretimų laidininku $L=2 \mathrm{~mm}$, laidininko storis $t=0,2 \mathrm{~mm}$, atstumas nuo meandrinio laidininko iki ekrano $w_{2}=0,5 \mathrm{~mm}$, sistemos ilgis $L_{\mathrm{s}}=29,5 \mathrm{~mm}$. Hibridinės ir meandrinès lètinimo sistemų centrinès srities laidininkų matmenys sutampa, išskyrus 
sumažintą iki $7 \mathrm{~mm}$ centrinio laidininko ilgị HLS, siekiant gauti norimą sistemos lètinimo koeficientą. HLS kraštinès meandrinio laidininko sritys pakeistos erdvinėmis ritėmis, kurių skersmuo 2,5 $\mathrm{mm}$.

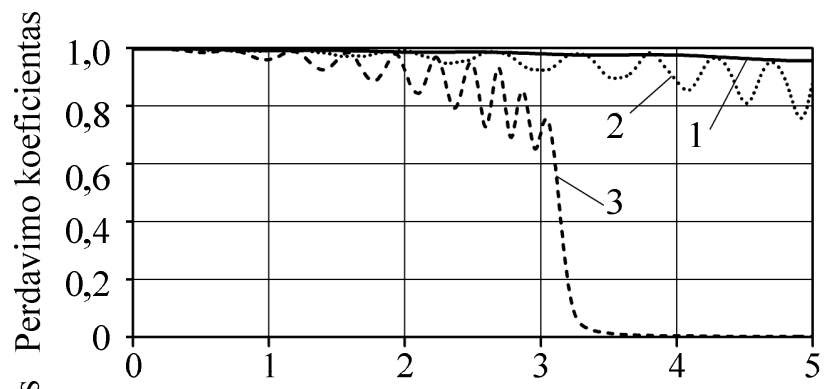

(a)

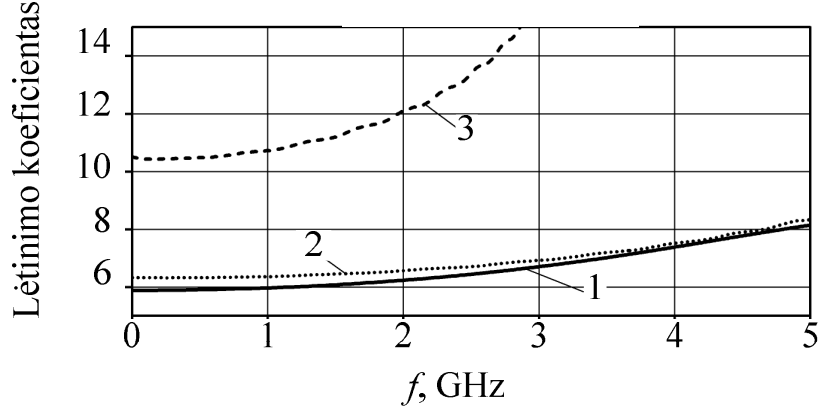

(b)

3.25 pav. Meandrinès ir hibridinès lètinimo sistemų dažninè amplitudès (a) ir lètinimo koeficiento (b) charakteristikos (Daškevičius et al. 2010): 1 - meandrinè sistema; 2 - hibridinė sistema (kraštinèse srityse viena kilpa); 3 - hibridinė sistema (kraštinèse srityse dviguba kilpa

Fig. 3.25. Retardation factor of meander and hybrid slow-wave systems (a) and transfer characteristics of the signal paths (b) (Daškevičius et al. 2010): 1 - meander system; 2 - hybrid meander system (one turn in peripheral parts); 3 - hybrid meander system (dual turn in peripheral parts)

3.25 paveiksle 1 kreivès apibūdina meandrinès lètinimo sistemos dispersines savybes. Sistemos lètinimo koeficientas yra mažesnis nei konstrukcinis lètinimo koeficientas $k_{\mathrm{L}}=2 a / L=7,5.3 .25$ paveiksle 2 kreivès apibūdina hibridinès lètinimo sistemos, kurios kraštines sritis sudaro vienos kilpos induktyvūs elementai. Naudojant tokią sistemą galima ženkliai padidinti sistemos iejjimo varžą ir užtikrinti plačią pralaidumo juostą. Hibridinès lètinimo sistemos apskaičiuota iejjimo varža yra lygi $Z_{\mathrm{IN}}=110 \Omega$, kai aptartos meandrinès sistemos buvo $65 \Omega$. Dar ženkliau padidinti iejjimo varžą galima kraštinèse meandrinio laidininko srityse naudojant dvigubas kilpas (3.25 pav. 3 kreivès). Tokios hibridinès lètinimo sistemos iejjimo varža $Z_{\mathrm{IN}}=185 \Omega$. Taikant dvigubas kilpas kraštinèse meandri- 
nio laidininko dalyse taip pat didejja ir lètinimo koeficiento vertès. Deja kartu didèja lètinimo koeficiento dispersija ir mažèja hibridinès lètinimo sistemos pralaidumo juostos ribos.

\subsection{Trečiojo skyriaus išvados}

Remiantis atliktais tyrimais ir jų rezultatų analize galima padaryti šias išvadas:

1. Sudaryti spiralinès, meandrinès ir hibridinès lètinimo sistemų matematiniai modeliai bei tyrimo algoritmai leidžia įvertinti lètinimo sistemų periodinius netolygus lemiančius veiksnius ir jų įtaką lètinimo sistemų savybèms.

2. Tyrimais parodyta, kad dèl periodinių netolygumų ir nuo jų atsiradusių daugkartinių atspindžių, kai fazių skirtumo kampas tarp gretimų lètinimo sistemos laidininkų ịtampų arba srovių artèja prie $\pi / 2$ arba $\pi$, lètinimo sistemos ịgauna užtvarinių filtrų savybių.

3. Tyrimais parodyta, kad turinčių periodinių netolygumų lètinimo sistemų dispersinès savybės gali būti pagerintos, mažinant laidininkų vienalyčių sričių banginių varžų kitimą, mažinant trumpesnès vienalytès srities ilgị išilgai laidininko vijos bei trumpinant netolygumų periodą, t. y. didinant netolygumų periodų skaičių išilgai laidininko vijos.

4. Tyrimais parodyta, kad didinant elektroninio įtaiso, turinčio kreipimolètinimo sistemą, jautrumą ir naudojant meandro formos elektrodus su plačiu centriniu laidininku bei siaurais laidininkais kraštuose, svarbu išvengti meandrinio laidininko skersinio asimetriškumo, kuris siaurina itaiso pralaidumo juostą.

5. Naudojant hibridinę lètinimo sistemą, t. y. kraštines meandrinio laidininko sritis keičiant spiralès formos vijomis, pavyksta padidinti sistemos iejjimo varžą ir lètinimo koeficientą.

6. Sudarytų lètinimo sistemų matematinių modulių ir jų tyrimo algoritmų adekvatumas patikrintas skaitiniais metodais, naudojant specializuotą programinę ịrangą. 


\section{4}

\section{Lètinimo sistemų tyrimas taikant dirbtinių neuronų tinklus}

Šiame skyriuje nagrinèjamos dirbtinių neuronų tinklų taikymo mikrobangų įtaisų tyrimuose galimybès. Pateikiama apibendrinta informacija, kokie uždaviniai gali būti sprendžiami taikant neuronų tinklus, kokios problemos kyla pritaikant dirbtinių neuronų tinklus mikrobangų srities uždaviniams spręsti ir kokie kylančių problemų sprendimo būdai. Sudaromi algoritmai, leidžiantys pereiti nuo iteracinių analitinių ir skaitinių metodų prie neuronų tinklų metodų. Pateikiami algoritmai lètinimo sistemų analizès ir sintezès uždaviniams spręsti.

Skyriaus tema paskelbti trys autoriaus straipsniai (Katkevičius et al. 2012; Katkevičius, Martavičius 2012; Katkevičius 2012).

\subsection{Prognozès algoritmai taikant dirbtinių neuronų tinklus}

Vystantis mikrobangų įtaisams, plečiantis lètinimo sistemų taikymo sritims, atsiranda poreikis kurti sudètingesnès konstrukcijos lètinimo sistemas. Kartu sudètingèja ir lètinimo sistemų projektavimo procesas, todèl vis aktualesniu uždavi- 
niu tampa sudètingesnių modeliavimo ir kompiuterinio projektavimo technologijų kūrimas.

\subsubsection{Dirbtinių neuronų tinklų taikymo galimybių analizè}

Analizuojant mikrobangu įtaisus reikalingas tikslus elektromagnetinis imitatorius, galintis tiesiogiai išspręsti ịtaisą apibūdinančias Maksvelo lygtis. Ieškant naujų mikrobangu įtaisu kompiuterinio projektavimo algoritmų, svarbiausiais kriterijais įvardijama: tikslumas, kompiuteriniai resursai, laiko sąnaudos.

Siuo metu mikrobangų įtaisai, tarp jų ir lètinimo sistemos, analizuojami remiantis ivvairiais metodais (Kabir et al. 2010). Plačiąa prasme jie skirstomi i analitinius ir skaitinius (Štaras et al. 2012). Taikant analitinius metodus susiduriama su problemomis sudarant sudètingų lètinimo sistemų matematinius modelius bei vertinant sistemos galų efektus. Skaitiniai metodai yra lankstesni ir tikslesni, bet reikalauja didelių kompiuterinių resursų ir laiko sąnaudų. Ypač tai aktualu pakartotinai vykdant modelio analizę, parenkant vis kitus sistemos parametrus. Be to, taikant tradicinius metodus sunku spręsti atvirkščią analizei sintezès uždavinị. Šios problemos lètina analizès procesą ir apriboja visą modeliavimo technologiją.

Aukščiau išvardinti trūkumai išryškejja, taikant automatizuotus lètinimo sistemų tyrimo metodus - kompiuterizuotas sistemas, kurias valdo specializuoti programu paketai (Štaras et al. 2010). 4.1 paveiksle pateikta apibendrintoji lètinimo sistemu automatizuoto projektavimo schema. Kaip teigia monografijos autoriai, mikrobangu irenginys projektuojamas daugeliu etapų. Dirbtinius neuronų tinklus verta taikyti konstrukcijos pradinio varianto sintezei, pradinio varianto analizei, pradinio varianto koregavimui, jei reikia, ir naujo varianto analizei. Nagrinejant automatizuoto lètinimo sistemų projektavimo sistemas, išryškejjo dar vienas spręstinas klausimas - galimybė išsaugoti tyrèjo patirtị.

Pirmuoju automatizuoto projektavimo etapu (4.1 pav. 1-4 blokai) projektuotojas, panaudodamas savo patirtị ir sintezès metodus, sintezuoja pradinị lètinimo sistemos variantą. Antruoju projektavimo etapu (4.1 pav. 5 ir 7 blokai) analizuojamas pradinis lètinimo sistemos konstrukcijos variantas. Analizès metu apskaičiuotos charakteristikos palyginamos su techniniais reikalavimais. Jeigu palyginimo rezultatai yra netinkami, modelio parametrai keičiami ir vèl kartojama analizès procedūra. Taip prasideda lètinimo sistemos optimizavimo procesas (4.1 pav. 10 ir 11 blokai). Optimizavimo procesui palengvinti, prieš įvedant pakeitimus, gali būti analizuojamas lètinimo sistemos parametru jautrumas pakeitimams. Projektuojamos lètinimo sistemos charakteristikų analizès, jų palyginimo su techniniais reikalavimais ir modelio parametru pakeitimų operacijos kartojamos tol, kol bus pasiekti visi techniniai reikalavimai. Po to gaminamas 
projektuojamos lètinimo sistemos bandomasis maketas ir matuojamos jo charakteristikos (4.1 pav. 8 blokas).

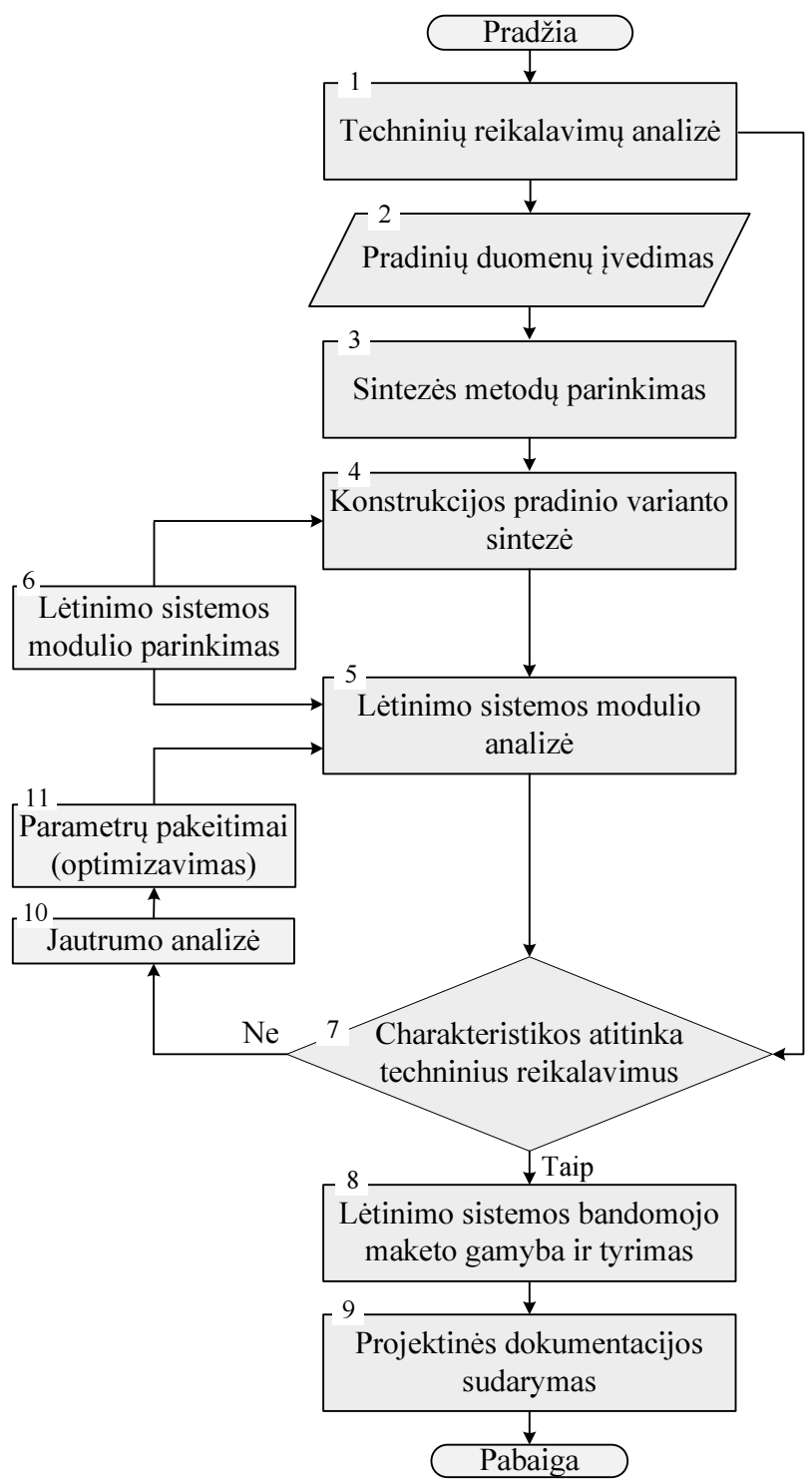

4.1 pav. Apibendrintoji lètinimo sistemų automatizuoto projektavimo proceso schema (Štaras et al. 2012)

Fig. 4.1. The block diagram illustrating the process of computer-aided design of electrodynamical slow-wave systems (Štaras et al. 2012) 
Ištyrus bandomaji sistemos maketą rengiama konstrukcijos technologinè dokumentacija (4.1 pav. 9 blokas) ir gaminama suprojektuota lètinimo sistema.

Lètinimo sistemos projektavimo procese yra svarbu tinkamai parinkti projektuojamos lètinimo sistemos matematinị modelị, sintezès ir optimizavimo metodus. Tada galima iki minimumo sumažinti eksperimentinius tyrimus ir projektavimo išlaidas.

Sintezès, analizès ir optimizavimo algoritmai automatizuoto projektavimo sistemose ịgyvendinami panašiais metodais. Visiems trims etapams taikomi iteraciniai skaičiavimai, reikalaujantys didelių laiko resursų. Pavyzdžiui dažniausiai sintezès algoritmas igyvendinamas keičiant tik vieną konstrukcijos parametrą, labiausiai įtakojantį vieną iš elektrinių parametrų tol, kol gaunama reikiama šio elektrinio parametro verte žemuosiuose dažniuose. Šio proceso metu kitų parametrų vertès fiksuotos. Toliau keičiamas kitas konstrukcinis parametras, labiausiai įtakojantis kitą elektrinị parametrą ir t. t.

Šių problemų galima išvengti taikant dirbtinių neuronų tinklus (DNT). Teisingai apmokius neuronų tinklą, vèliau sintezès, analizès ir optimizavimo metu galima iš karto prognozuoti visų lètinimo sistemos konstrukcijos parametrų rinkinius, atsisakant didelių kompiuterinių resursų ir laiko reikalaujančių analitinių ir skaitinių iteracinių priartejjimo skaičiavimo metodų. Taip pat kiekvieną kartą atliekant skaičiavimus ir papildant mokymo duomenų pavyzdžių rinkinius gali būti išsaugoma atskirų tyrèjų patirtis.

Neuronų tinklus sudaro atskirų neuronų visuma. 4.2 paveiksle pavaizduotas bendras neurono modelis, kuriame galima išskirti tris pagrindinius elementus: ryšių svorių vektorius, sumatorių ir aktyvavimo funkciją (Kabir et al. 2010). Sumatorius sumuoja iẹjimo signalus, padaugintus iš atitinkamų ryšių svorių, ivertinant slenksčio signalo įtaką. Aktyvavimo funkcija apriboja neurono išejimo signalo amplitudę.

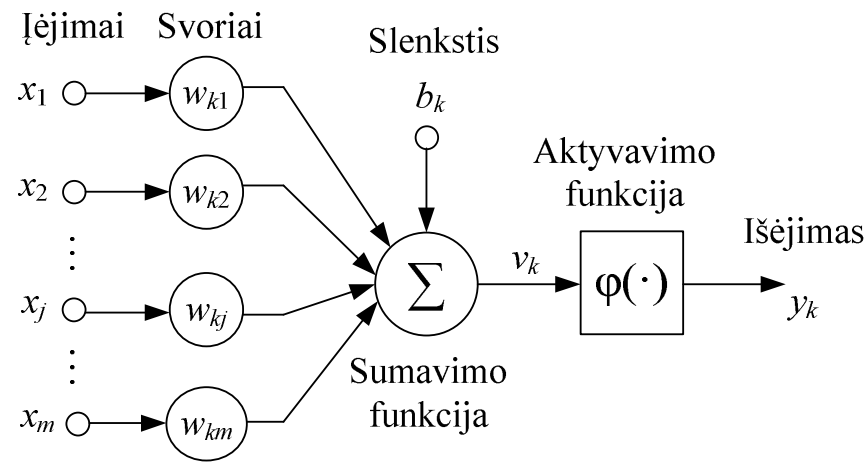

4.2 pav. Neurono modelis

Fig. 4.2. The model of the neuron 
Neurono modelio slenkstis $b_{k}$ priklausomai nuo ženklo didina arba mažina aktyvavimo funkcijos įejimo signalų lygị. Neuronų tinklo veikimą nusako lygčių pora (Kabir et al. 2010):

$$
\begin{gathered}
u_{k}=\sum_{j=1}^{m} w_{k j} x_{j}, \\
y_{k}=\varphi\left(u_{k}+b_{k}\right),
\end{gathered}
$$

čia $x_{1}, x_{2}, \ldots x_{m}$ - iejjimo signalai; $w_{k 1}, w_{k 2}, \ldots w_{k m}$ - neurono ryšių svoriai; $b_{k}-$ slenkstis; $\varphi(\bullet)$ - aktyvavimo funkcija; $y_{k}$ - neurono išejimo signalas; $k$ - neurono numeris sluoksnyje.

Aktyvavimo funkcija gali būti įvairių tipų. Pagrindiniai iš jų yra slenksčio, rampos, sigmoidine, hiperbolinio tangento. Dirbtinių neuronų tinklai skirstomi i vieno sluoksnio ir daugiasluoksnius. Vieno sluoksnio tinklas turi įejjimo ir išèjimo sluoksnius. Daugiasluoksnis neuronų tinklas papildomai turi tam tikrą nuo sprendžiamo uždavinio ir tinklo struktūros priklausanti paslèptuju sluoksnių skaičių.

Neuronų tinklais prognozuojami daugiamačiai netiesiniai ryšiai tarp įvesties ir išvesties parametrų, naudojant paprastas formules, aprašytas (4.1), (4.2) išraiškomis. Kuo didesnis neuronų skaičius iejjimo sluoksnyje, tuo lengviau neuronų tinklas susidoroja su daugiamačiais įvesties duomenimis. Didinant neuronų skaičiu paslèptajame sluoksnyje efektyviau susidorojama su netiesiškumais tarp įèjimo signalų $x$ ir išejjimo signalų $y$ vektorių duomenų, nei taikant aproksimavimą polinomu ar kitus aproksimavimo metodus.

\subsubsection{Analizès ir projektavimo algoritmai taikant dirbtinių neuronų tinklus}

Dirbtinių neuronų tinklai gali būti taikomi daugeliui skirtingų mikrobangų ịtaisų modeliavimo uždaviniams spręsti. Mikrobangų įtaisų modeliavimo procesas gali būti suskirstytas ị tris etapus: pirminių sistemos parametrų nustatymas; tiesinių dispersinių lygčių sistemos sprendimas; elektrodinaminių mikrobangų įtaisų parametru įvertinimas.

Šiame skyriuje pateikiame lètinimo sistemų analizès algoritmą, taikant dirbtinių neuronų tinklus, kuris leidžia išvengti didelių laiko sąnaudų reikalaujančių iteracinių skaičiavimų, ieškant sistemos dispersinès lygties sprendinių. Dirbtinių neuronų tinklų vieta bendrame mikrobangų itaisų modeliavimo procese matyti iš 1 algoritmo. Tyrimuose taikome spindulio tipo bazinių funkcijų tinklą (SBF) ir daugiasluoksnị perceptronų tinklą (DPT). 
1 algoritmas. Mikrobangų ịtaisų modeliavimo algoritmas

Algorithm 1. Modeling algorithm of microwave devices

A. Itaiso modelio pasirinkimas

- Itaiso modeli apibūdinančių įvesties/išvesties parametrų parinkimas.

- Pavyzdžių rinkimas, naudojant iteracinius arba skaitinius metodus.

B. Neuronų tinklo mokymas.

- Interpoliavimas.

- Iejjimų susiejimas su išèjimais.

- Dirbtinių neuronų tinklo mokymas.

- Dirbtinių neuronų tinklo apmokymo patikra.

C. Modeliavimas, taikant daugiasluoksni perceptronų tinklą.

D. Rezultatų koregavimas.

Lètinimo sistemu tyrimams naudojamo daugiasluoksnio perceptronų tinklo taikymo procedūrą sudaro keturi žingsniai (2 algoritmas). Pirmame žingsnyje taikant iprastus analitinius iteracinius skaičiavimo metodus surenkamos mokymo duomenų pavyzdžių sekos. Pavyzdžių sekas sudaro lètinimo sistemos dažninių lètinimo koeficiento ir iejjimo varžos charakteristikų priklausomybès nuo dažnio duomenų rinkiniai.

Siekiant teisingai apmokyti daugiasluoksni perceptronų tinklą, būtinas minimalus mokymo duomenų pavyzdžių rinkinys, kuriame duomenys surinkti reikiamą tikslumą užtikrinančiu žingsniu. Antrame etape siekiant padidinti mokymo duomenų pavyzdžių rinkinius, mažinant žingsni tarp greta esančių mokymo duomenų taškų, tarpiniai taškai generuojami, taikant SBF ir atliekant interpoliavimo procedūrą.

2 algoritmas. Mikrobangų ịtaisų analizès algoritmas

Algorithm 2. Sequence of analysis actions of slow-wave systems

A. Mokymo duomenų pavyzdžių rinkimas SBF tinklo mokymui.

- Lètinimo koeficiento $k_{\mathrm{L}}$ ir ịejimo varžos $Z_{\mathrm{IN}}$ priklausomybès nuo dažnio duomenu rinkimas.

B. Tarpinių duomenų interpoliavimas taikant SBF.

C. Daugiasluoksnio perceptronų tinklo mokymas.

- Nuo dažnio priklausančių lètinimo koeficiento, iejjimo varžos ir ribinių dažnių, nurodančių pralaidumo juostų ribas, parametrų ryšių ịsiminimas su vienalyčių sričių ilgių ir banginių varžų parametrais.

D. Modeliavimas, taikant DPT.

- Lètinimo koeficiento, ièjimo varžos ir ribinių dažnių, nurodančių pralaidumo juostų ribas, prognozė, žinant vienalyčių sričių ilgių ir banginių varžų parametrus. 


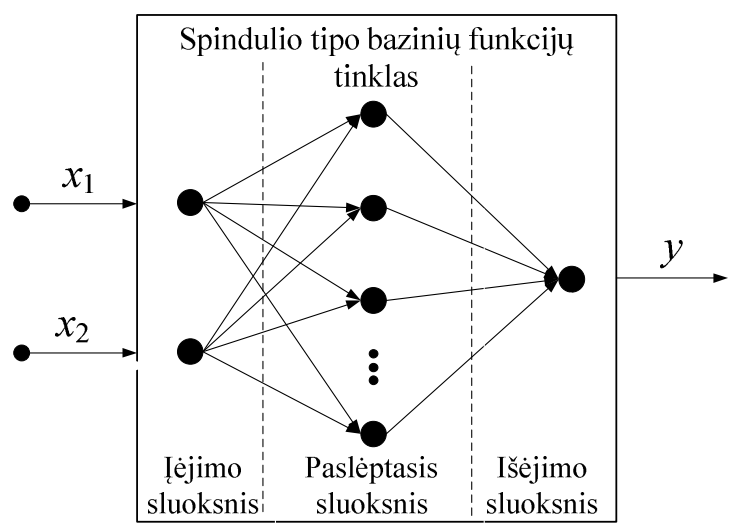

4.3 pav. Spindulio tipo bazinių funkcijų tinklo struktūra, naudojama papildomų mokymo duomenų taškų interpoliavimui

Fig. 4.3. Structure diagram of the radial basis function network, used for interpolation of the additional intermediate points

SBF struktūra pateikta 4.3 paveiksle. SBF tinklas turi įejjimo, išèjimo ir paslèptajj sluoksnius. Paslèptasis sluoksnis yra spindulio tipo bazinių funkcijų sluoksnis. Gauso funkciju parametrai yra atnaujinami SBF mokymo metu minimizuojant Euklido atstumą tarp esančio ir laukiamo rezultato. SBF mokymo metu taip pat pridedami nauji neuronai ị paslèptaji sluoksnį, kol pasiekiama nustatyta vidutinè kvadratinè paklaida tarp laukiamo ir esamo rezultatų.

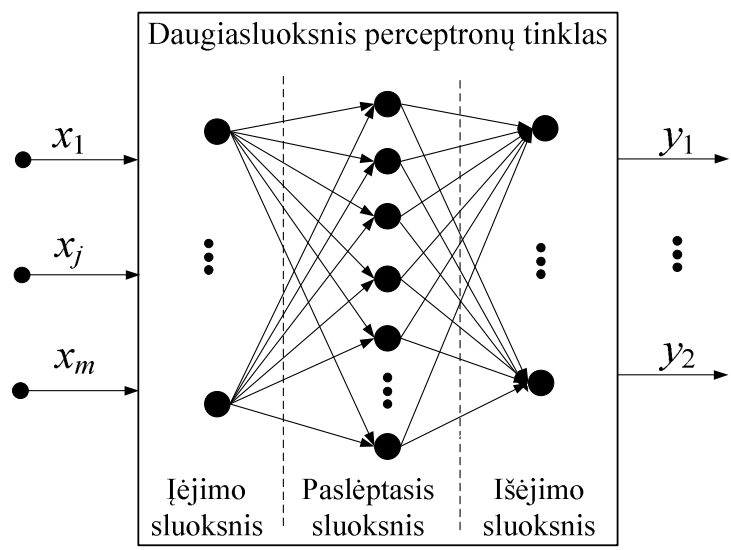

4.4 pav. Daugiasluoksnio perceptronų tinklo struktūra, naudojama mikrobangų ịtaisų modeliavimui

Fig. 4.4. Structure diagram of the multilayer perceptron network, used for microwave device simulation 
Trečiame etape pasirenkama DPT struktūra. DPT struktūra priklauso nuo vykdomos užduoties ir taipogi nuo DPT mokymui gautų mokymo duomenų rinkinių. Ketvirtame etape DPT mokomas ir priklausomai nuo mokymo rezultatu DPT struktūra gali būti koreguojama, keičiant neuronų skaičių paslèptajame sluoksnyje. Bendra DPT struktūra pateikta 4.4 paveiksle.

DPT sudaro ièjimo, išèjimo ir paslèptasis sluoksniai. İèjimo sluoksnis lygus iejjimo kintamujų skaičiui. Išejimo sluoksnis lygus sistemos atsako kintamujų skaičiui. Paslèptojo sluoksnio neuronai apdoroja iš įèjimo sluoksnio gautus požymius, nustatant ryšių svorius ir naudojant specifines perdavimo funkcijas. Išèjimo sluoksnyje paslèptojo sluoksnio išejimai apdorojami taikant tiesinio aktyvavimo funkcijas.

2 algoritmas yra skirtas spręsti lètinimo sistemų analizès uždavinį, kai žinant sistemos geometrinių ir fizinių parametrų rinkinius, ieškoma elektrinių parametrų rinkinių. Sprendžiant sintezès uždavinị duomenų susiejimas vykdomas priešinga kryptimi - ieškoma fizinių ir geometrinių parametrų rinkinių, žinant elektrinių parametrų rinkinį. Sprendžiant sintezès uždavinį, veiksmų seka yra panaši ị analizès uždavinio veiksmų seką (2 algoritmas).

Sprendžiant LS sintezès uždavinị visų pirma surenkami mokymo duomenų pavyzdžių rinkiniai, taikant analitinius iteracinius metodus (3 algoritmas). Randami sistemos elektriniai parametrai, pasirinkus tam tikrą geometrinių ir fizikinių parametrų rinkinį. Sprendžiant sintezès uždavinị neuronų tinklo mokymo proceso metu dažnai susiduriama su problema, kai nepavyksta rasti vieno unikalaus sprendimo, nes tos pačios įejjimo vertès susiejamos su daug skirtingų sprendinių išejime.

3 algoritmas. Lètinimo sistemų sintezės algoritmas

Algorithm 3. Sequence of synthesis actions of slow-wave systems

A. Mokymo duomenų pavyzdžių rinkimas.

- Lètinimo sistemos vienalyčiu sričių ilgiụ ir banginių varžų parametrų priklausomybès nuo sistemos lètinimo koeficiento, iejjimo varžos ir užtvarinės juostos pločio parametrų rinkimas.

B. Duomenų grupavimas ị unikalias grupes.

C. Daugiasluoksnio perceptronų tinklo mokymas.

- Lètinimo sistemos vienalyčiu sričiu ilgiụ ir banginių varžų pavyzdžiu rinkinių ryšių ịsiminimas su lètinimo koeficiento, ịejjimo varžos ir užtvarinès juostos pločio parametrų rinkiniais.

D. Modeliavimas, taikant DPT.

- Lètinimo sistemos vienalyčiu sričiu ilgiu ir banginių varžų rinkinių prognozè, žinant lètinimo koeficiento, iejjimo varžos ir užtvarinès juostos pločio parametrų rinkinius. 
Dèl šios priežasties neuronų tinklo mokymo procesas sudètingèja, nes neuronų tinklas negali būti tiksliai apmokytas. Antrame žingsnyje mokymo duomenu pavyzdžių rinkiniai sugrupuojami remiantis vedinio informacija taip, kad suformuotos atskiros duomenų grupès nebeturètų bendru sprendinių problemos. Tuomet daugiasluoksnis perceptronu tinklas apmokomas ir vèliau naudojamas lètinimo sistemų parametrų susiejimui.

Aptarus bendrą perejjimo nuo analitinių ir skaitinių iteracinių metodų prie dirbtinių neuronų tinklais paremtų metodų algoritmą, išanalizavus bendrus dirbtinių neuronų tinklais paremtus automatizuoto lètinimo sistemų projektavimo algoritmus, sekančiame poskyryje aptariami konkretūs lètinimo sistemų analizès ir sintezès pavyzdžiai, taikant dirbtinių neuronų tinklus. Rezultatai, gauti taikant dirbtinių neuronų tinklus palyginami su rezultatais, gautais, taikant tradicinius analitinius iteracinius metodus.

\subsection{Prognozès rezultatai taikant dirbtinių neuronų tinklus}

Šiame poskyryje prognozuojamos meandrinès ir spiralinès konstrukcijos lètinimo sistemų charakteristikos, taikant dirbtinių neuronų tinklų metodus. Pateikti analizès ir sintezès uždavinių rezultatai. Dirbtinių neuronų tinklais prognozuoti rezultatai lyginami su daugialaidžių linijų iteraciniu metodu gautais rezultatais. Daugialaidžių linijų metodu gauti rezultatai laikomi etalonu.

\subsubsection{Analizès rezultatai taikant dirbtinių neuronų tinklus}

3.9 paveiksle pateikta skersiniu asimetriškumu pasižyminti meandrinè lètinimo sistema. Skersinis asimetriškumas gali atsirasti dèl gamybos broko ir kitų priežasčių. Dèl gamybinio broko kraštinių sričių storiai skiriasi arba centrinè meandro dalis yra pastumta link vieno iš kraštų. Tokios sistemos tyrimas yra aktualus - dèl asimetrinių netolygumų gali susiaurèti meandrinès sistemos pralaidumo juosta.

4.5 paveiksle pateiktos meandrinès lètinimo sistemos dažninès lètinimo koeficiento ir įejimo varžos charakteristikos, kai sistemos nevienalytiškumo periodą sudaro trys vienalytès sritys bei meandrinis elektrodas yra ne simetriškas per centrinę dalį einančios statmenos plokštumos atžvilgiu.

Kai meandro laidininko banginès varžos visose trijose srityse yra vienodos, t. y. sistema vienalyte, dažninèse meandrinès lètinimo sistemos charakteristikose trūkių nèra (4.5 pav. a ir b, 1 kreivè). Vienalytés meandrinès sistemos pasižymi didele lètinimo koeficiento dispersija ir mažu įèjimo varžos kitimu. 
Siekiant pagerinti bėgančiosios bangos vamzdžių jautrumą bei padidinti signalų trakto varžą bėgančiosios bangos kreipimo sistemose praplatinta meandrinio elektrodo centrinè dalis bei susiaurintos periferinès dalys. Tokios meandrinès sistemos dažninès charakteristikos iliustruotos 4.5 paveiksluose (a) ir (b) 2 kreivès. Sistemos iejjimo varža radikaliai kinta ir susiformuoja užtvarinè juosta, kai fazès kampas $\theta$ tarp gretimų laidininkų ịtampų arba srovių pasiekia $\pi$, o dažnis pasiekia (3.38). Didejjant banginių varžų $Z(0)$ ir $Z(\pi)$ kitimui, užtvarinès juostos plotis ties $\theta=\pi$ taip pat dideja (3.11 pav. a ir b, 3 kreivè).
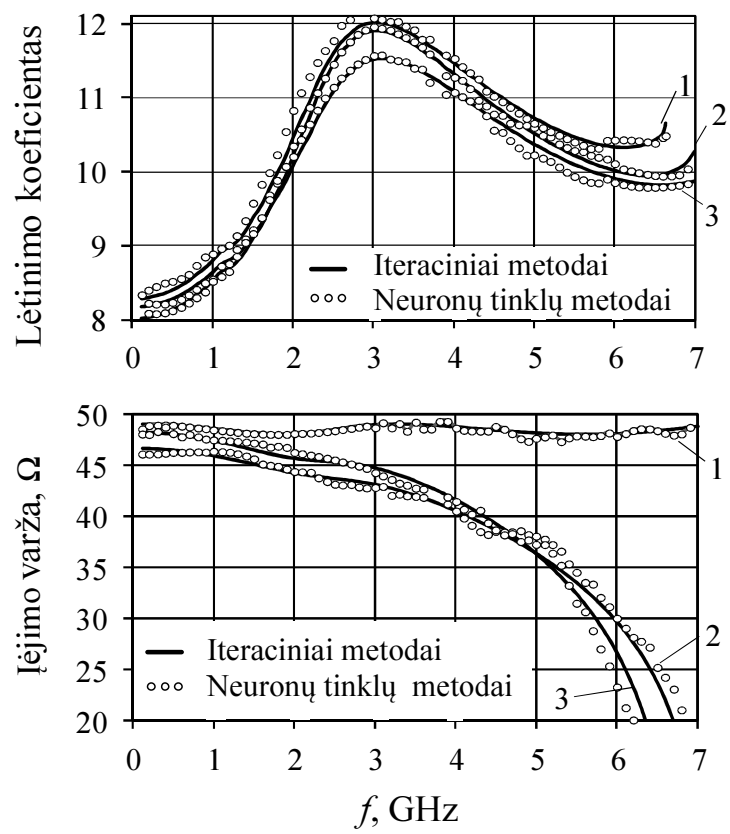

(b)

4.5 pav. Meandrinès lètinimo sistemos lètinimo koeficiento (a) ir ịjimo varžos (b) priklausomybė nuo dažnio, taikant iteracinị ir neuronų tinklų metodus, kai $l_{1}+l_{2}+l_{3}=20 \mathrm{~mm}, l_{1}=l_{3}=5 \mathrm{~mm}, l_{2}=10 \mathrm{~mm}$ ir $L=2 \mathrm{~mm}$ bei:

$1-Z_{1}(0)=60 \Omega, Z_{1}(\pi)=40 \Omega, Z_{2}(0)=60 \Omega, Z_{2}(\pi)=40 \Omega, Z_{3}(0)=60 \Omega, Z_{3}(\pi)=40 \Omega$;

$2-Z_{1}(0)=60 \Omega, Z_{1}(\pi)=40 \Omega, Z_{2}(0)=50 \Omega, Z_{2}(\pi)=30 \Omega, Z_{3}(0)=60 \Omega, Z_{3}(\pi)=40 \Omega$;

$3-Z_{1}(0)=70 \Omega, Z_{1}(\pi)=50 \Omega, Z_{2}(0)=50 \Omega, Z_{2}(\pi)=30 \Omega, Z_{3}(0)=70 \Omega, Z_{3}(\pi)=50 \Omega$

Fig. 4.5. Retardation factor (a) and input impedance (b) versus frequency of the meander slow-wave system using iterative and artificial neural network methods at $l_{1}+l_{2}+l_{3}=20 \mathrm{~mm}, l_{1}=l_{3}=5 \mathrm{~mm}, l_{2}=10 \mathrm{~mm}$ ir $L=2 \mathrm{~mm}$ and:

$1-Z_{1}(0)=60 \Omega, Z_{1}(\pi)=40 \Omega, Z_{2}(0)=60 \Omega, Z_{2}(\pi)=40 \Omega, Z_{3}(0)=60 \Omega, Z_{3}(\pi)=40 \Omega$;

$2-Z_{1}(0)=60 \Omega, Z_{1}(\pi)=40 \Omega, Z_{2}(0)=50 \Omega, Z_{2}(\pi)=30 \Omega, Z_{3}(0)=60 \Omega, Z_{3}(\pi)=40 \Omega$; $3-Z_{1}(0)=70 \Omega, Z_{1}(\pi)=50 \Omega, Z_{2}(0)=50 \Omega, Z_{2}(\pi)=30 \Omega, Z_{3}(0)=70 \Omega, Z_{3}(\pi)=50 \Omega$ 
Atliekant tyrimą visų pirma daugialaidžių linijų metodu surinkta 45 pavyzdžių rinkiniai, ịvertinant kintančius dažnio, vienalyčių sričių banginių varžų ir vienalyčių sričiu ilgių parametrus. Kiekvieną pavyzdžių rinkinį sudare $1 \times 60$ ịèjimo ir $2 \times 60$ dydžio tikslo matricos. Mokymo duomenu pavyzdžių rinkiniai padidinti atliekant interpoliavimą su SBF. I SBF iejjimą paduotas vienas dažnio $f$ parametras. Tikslo matricą išèjime sudare lètinimo koeficiento ir iejjimo varžos parametrai. Po interpoliacijos su SBF iejjimo matrica $[f]$ padidinta iki $1 \times 600$, o tikslo matrica $\left[k_{\mathrm{L}} ; Z_{\mathrm{IN}}\right]$ iki $2 \times 600$.

Didesnès mokymo duomenų pavyzdžių sekos padidino DPT apsimokymo ir prognozavimo tikslumą. DPT ịvesties sluoksnị sudare 7 neuronai: dažnis $f$ ir vienalyčių sričių banginès varžos $Z_{1}(0), Z_{1}(\pi), Z_{2}(0), Z_{2}(\pi), Z_{3}(0)$ ir $Z_{3}(\pi)$. Kadangi tiriamas kraštinių sričių nevienalytiškumas, vienalyčių sričių ilgiai $l_{1}=l_{3}=5 \mathrm{~mm}$ ir $l_{2}=10 \mathrm{~mm}$ nekito. Išèjime prognozuotos lètinimo koeficiento $k_{\mathrm{L}}$ ir iejjimo varžos $Z_{\mathrm{IN}}$ charakteristikų priklausomybè nuo dažnio, todèl išejjimo sluoksnị sudare 3 neuronai. Bendras ịvesties matricos dydis $7 \times 21000$, bendras tikslo matricos dydis $3 \times 21000$. Paslèptaji sluoksnį sudare 28 neuronai.

Taikyta tangento sigmoidiné paslèptojo sluoksnio neuronu aktyvacijos funkcija ir tiesinè išejimo sluoksnio neuronų aktyvacijos funkcija. Taikytas atgalinio sklidimo mokymo algoritmas, optimizuotas igyvendinimui įterptinèse sistemose, sandaugą iš klaidos gradiento pakeičiant ženklo keitimo operacija. Atliekant mokymą daugiasluoksnis perceptronų tinklas apmokytas su kiekvienu atskiru lètinimo sistemos pavyzdžiu po 10 kartų. Viso mokymo metu naudoti 45 pavyzdžių rinkiniai.

DNT prognozuoti rezultatai panašūs ị daugialaidžių linijų metodais gautus rezultatus. Visgi rezultatų svyravimai nuo etaloninių daugialaidžių linijų metodais gautų rezultatų svyruoja nuo $5 \%$ iki $15 \%$. Svyravimai atsiranda, nes DNT sunkiau prognozuoja rezultatus nagrinejjamų sričių kraštinèse srityse. DNT rezultatų svyravimai nuo etaloninių priklauso ir nuo etaloninių charakteristikų kitimo greičio. Prognozès tikslumas gali būti didinamas, mažinant žingsni tarp greta esančių mokymo duomenų taškų. Mažinant žingsnị didès DNT mokymo laikas, todèl tikslinga mažinti žingsnį tarp mokymo duomenų greta esančių taškų tik kraštinèse srityse ir srityse, kuriose yra staigus etaloninių charakteristikų kitimas.

Taikant dirbtinių neuronų tinklus dažniausiai ieškoma netrūkių charakteristikų. Kai ieškomos charakteristikos yra trūkios susiduriama su papildomomis problemomis, nes standartinès slenksčio, rampos, sigmoidine, hiperbolinio tangento aktyvacijos funkcijos nesugeba aproksimuoti trūkio taškų ir neuronų tinklas neapsimoko ties trūkio sritimis.

4.6 paveiksle pateikti SLS lètinimo koeficiento skaičiavimo rezultatai, turintys trūkio taškus. Esant trūkio taškams DPT papildomai turi būti apmokomas 
prognozuoti pralaidumo juostų ribinius dažnius. Radus pralaidumo juostų ribinius dažnius uždavinys skaidomas ir prognozavimas atliekamas kiekvienai pralaidumo juostai atskirai, išvengiant trūkio taškų, naudojant kelių neuronų tinklų derini. Kiekvienas neuronų tinklas apmokomas dirbti tam tikroje dažninès charakteristikos dažnių juostoje, taip eliminuojant atsirandančius trūkio taškus.

SLS skersinis pjūvis ir spiralès fragmentas yra pateikti 3.1 paveiksle. Spiralinis laidininkas sudarytas iš dviejų vienalyčių sričių, besiskiriančių savo ilgiais $l_{1}$ ir $l_{2}$ ir banginių varžų $Z_{1}(0), Z_{1}(\pi), Z_{2}(0)$ ir $Z_{2}(\pi)$ vertèmis. Analitiniais iteraciniais metodais ir DNT metodais gauti rezultatai lyginami 4.6 paveiksle.

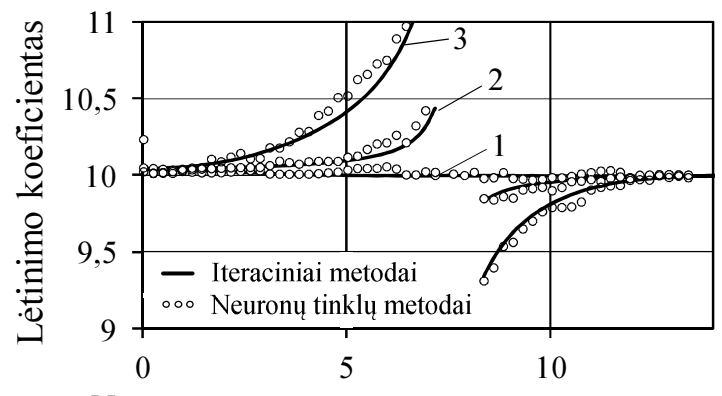

(a)

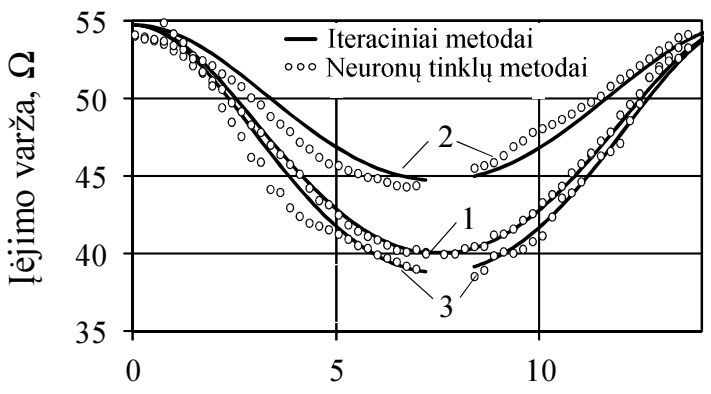

(b)

4.6 pav. Spiralinès lètinimo sistemos lètinimo koeficiento (a) ir ịjimo varžos (b) priklausomybè nuo dažnio, taikant iteracinị ir neuronų tinklų metodus, kai $l_{1}+l_{2}=20 \mathrm{~mm}, l_{1}=l_{2}=10 \mathrm{~mm}$ ir $L=2 \mathrm{~mm}$ ir:

$$
\begin{aligned}
& 1-Z_{1}(0)=60 \Omega, Z_{1}(\pi)=40, \Omega, Z_{2}(0)=50 \Omega, Z_{2}(\pi)=40 \Omega ; \\
& 2-Z_{1}(0)=60 \Omega, Z_{1}(\pi)=50, \Omega, Z_{2}(0)=50 \Omega, Z_{2}(\pi)=40 \Omega ; \\
& 3-Z_{1}(0)=60 \Omega, Z_{1}(\pi)=50, \Omega, Z_{2}(0)=50 \Omega, Z_{2}(\pi)=30 \Omega
\end{aligned}
$$

Fig. 4.6. Retardation factor (a) and input impedance (b) versus frequency of the helical slow-wave system using iterative and artificial neural network methods at

$l_{1}+l_{2}=20 \mathrm{~mm}, l_{1}=l_{2}=10 \mathrm{~mm}$ ir $L=2 \mathrm{~mm}$ and:

$$
\begin{aligned}
& 1-Z_{1}(0)=60 \Omega, Z_{1}(\pi)=40 \Omega, Z_{2}(0)=50 \Omega, Z_{2}(\pi)=40 \Omega ; \\
& 2-Z_{1}(0)=60 \Omega, Z_{1}(\pi)=50 \Omega, Z_{2}(0)=50 \Omega, Z_{2}(\pi)=40 \Omega ; \\
& 3-Z_{1}(0)=60 \Omega, Z_{1}(\pi)=50 \Omega, Z_{2}(0)=50 \Omega, Z_{2}(\pi)=30 \Omega
\end{aligned}
$$


Tokios struktūros lètinimo sistema tirta norint išsiaiškinti, kokią įtaką lètinimo sistemos dažninėms charakteristikoms turi kintantis sistemos periodinis nevienalytiškumas. Dèl periodinio nevienalytiškumo spiralinè lètinimo sistema igauna užtvarinio filtro savybes. Užtvarinès juostos centrinis dažnis priklauso nuo sistemos periodo vèlinimo trukmès $t_{\mathrm{v}}$ ir išreiškiamas formule (3.25). Taip pat buvo nustatyta, kad spiralinès sistemos dažninès charakteristikos (lètinimo koeficientas ir iejjimo varža) kinta radikaliai, kai fazès kampas $\theta$ artimas $\pi$. Tuomet elektromagnetinès bangos ilgis tampa dvigubai didesnis nei spiralès apvijos ilgis ir susidaro užtvarine juosta.

Užtvarinès juostos plotis priklauso nuo vienalyčių sričių banginių varžų $Z_{i}(\pi)$ santykio ir vienalyčių sričiu ilgių santykio. Norint sumažinti vẻlinimo dispersiją ir užtvarinès juostos plotị, reikia sumažinti vienalyčių sričių banginių varžų verčių santykị ties $\theta=\pi$ ir sumažinti trumpesnès vienalytès srities ilgi.

Spiralinès sistemos, turinčios periodinių netolygumų, iejjimo varža labai priklauso nuo koordinatės $x$ ir vienalyčių sričių ilgių santykio (4.6 pav. b, 4 kreivè).

Atliekant spiralinès konstrukcijos lètinimo sistemos duomenu prognozavimą DPT ịvesties sluoksnį sudare dažnis $f$; vienalyčių sričių ilgiai $l_{1}$ ir $l_{2}$ ir vienalyčių sričių banginès varžos $Z_{1}(0), Z_{1}(\pi), Z_{2}(0)$ ir $Z_{2}(\pi)$. Išèjime prognozuotos lètinimo koeficiento $k_{\mathrm{L}}$, ièjimo varžos $Z_{\mathrm{IN}}$ ir pralaidumo juostų ribinių dažnių charakteristikos. Atliekant tyrimą visų pirma daugialaidžių linijų metodu buvo surinkta 45 pavyzdžių rinkiniai, kai kinta dažnis, vienalyčių sričių banginès varžos ir vienalyčių sričiu ilgiai. Kiekvieną pavyzdžių rinkinį sudare $3 \times 60$ dydžio matricos. Bendras iqvesties matricos dydis $7 \times 21000$, bendras tikslo matricos dydis $7 \times 21000$.

Tiriant spiralines lètinimo sistemas įejimo sluoksnį sudare 7 neuronai, paslèptaji sluoksni sudare 28 neuronai ir išejimo sluoksnį sudare 6 neuronai. Taikyta paslëptojo sluoksnio neuronų aktyvacijos funkcija yra hiperbolinio tangento sigmoidinė ir tiesinè išèjimo sluoksnio neuronų aktyvavimo funkcija. Taikyta mokymo funkcija, kuri atnaujina ryšių svorių ir slenksčio vertes remiantis atspariu atgalinio sklidimo algoritmu. Atliekant mokymą DPT apmokytas su kiekvienu atskiru LS pavyzdžiu po 10 kartų. Viso mokymo metu naudoti 45 pavyzdžių rinkiniai.

Svarbu pabrèžti kad tarpinių taškų interpoliacija taikant SBF truko apytiksliai 0,16 s kiekvienam pavyzdžių rinkiniui, kai pavyzdžių rinkinio dydis $7 \times 60$. Bendras interpoliavimo procedūros laikas 1,34 s. DPT mokymo procesas užèmè 14 min. Prognozavimas, taikant daugiasluoksni perceptronų tinklą, truko apie $0,01 \mathrm{~s}$, kai analogiškų sistemų skaičiavimas, taikant analitinius iteracinius metodus, truko 4,65 s. Skaičiavimai atlikti vidutinio pajègumo kompiuteriu, taikant $\mathrm{MATLAB}^{\odot}$ programų paketą. 


\subsubsection{Projektavimo rezultatai taikant dirbtinių neuronų tinklus}

Sprendžiant atvirkštinius analizei sintezès uždavinius siekiama rasti sistemos geometrinius ir fizinius parametrus, žinant elektrinius mikrobangu itaisų parametrus. Sintezès uždavinio taikymo procedūra pateikta 3 algoritme.

Sprendžiant sintezès uždavinį svarbu atsižvelgti ị susidarančią unikalių sprendinių radimo problemą. Dažnai susiduriama su problema, kai nepavyksta rasti vieno unikalaus geometrinių ir fizikinių parametrų rinkinio, nes tos pačios elektrinių parametrų vertés galimos prie skirtingų geometrinių ir fizikinių parametrų rinkinių. Tuomet būtina atlikti mokymo duomenų grupavimą.

Lètinimo sistemų sintezès uždaviniui spręsti naudosime daugiasluoksni perceptronų tinklą, kurio bendroji struktūra pateikta 4.4 paveiksle. DPT struktūra priklauso nuo sprendžiamo uždavinio sudètingumo. Tinklo ieejjimo ir išèjimo sluoksniuose neuronų skaičius priklauso nuo tiriamų parametrų skaičiaus.

Šiuo konkrečiu atveju taikysime spiralinę lètinimo sistemą, sudarytą iš dviejų periodiškai kintančių vienalyčių sričių, besiskiriančių vienalyčių sričių lyginio ir nelyginio sužadinimo banginèmis varžomis $Z_{1}(0), Z_{1}(\pi), Z_{2}(0), Z_{2}(\pi)$ ir sričių ilgiais $l_{1}$ ir $l_{2}$ (3.1 pav.).

Iš 4.6 paveiksle pateiktų dažninių charakteristikų matyti, kad projektuojant spiralinę lètinimo sistemą vieni svarbiausių parametrų tampa lètinimo koeficiento $k_{\mathrm{L}}$, nepageidaujamos užtvarinès juostos pločio $\Delta F_{\mathrm{u}}$ ir sistemos ièjimo varžos $Z_{\text {IN }}$ vertès.

3.6 paveiksle pateiktas dalinis atvejis, parodantis, kaip priklauso spiralinès sistemos lètinimo koeficientas ir įejjimo varža, kintant vienalyčių sričių banginėms varžoms ir esant nelyginiam sužadinimui $\pi$, kai vienalyčių sričių ilgiai yra pastovūs (1-3 kreivès). Arba esant pastovioms banginèms varžoms $Z_{1}(0)=Z_{2}(\pi)$, kai kinta vienalyčių sričių ilgiai $l_{1}$ ir $l_{2}$ (2 ir 4 kreivès).

4.1 lentelè. Spiralinès lètinimo sistemos elektriniai parametrai

Table 4.1. Electrical parameters of helical slow-wave system

\begin{tabular}{|c|c|c|c|}
\hline Variantas & $\Delta \mathrm{F}_{\mathrm{u}}, \mathrm{GHz}$ & $k_{\mathrm{L}}$ & $Z_{\mathrm{IN}}, \Omega$ \\
\hline 1 & 0 & 10 & 40 \\
\hline 2 & 1,64 & 10,44 & 45 \\
\hline 3 & 2,72 & 11,8 & 38,8 \\
\hline
\end{tabular}

Tokį uždavinị spręsti yra sudètinga dèl pasikartojančios unikalių sprendinių problemos - nurodytus lètinimo koeficiento, iejjimo varžos ir spiralinès sistemos draudžiamosios juostos pločio elektrinių parametrų rinkinius galejo atitikti skirtingi geometrinių (vienalyčių sričių ilgiai $l_{1}$ ir $l_{2}$ ) ir fizikinių (vienalyčių sričių 
banginès varžos $\left.Z_{1}(0), Z_{1}(\pi), Z_{2}(0), Z_{2}(\pi)\right)$ parametrų rinkiniai. Siekiant sumažinti unikalių sprendinių pasikartojimo problemos įtaką buvo priimta, kad visais atvejais vienalyčių sričių ilgiai lygūs $l_{1}=l_{2}=10 \mathrm{~mm}$ (4.1 lentelè).

Tinklo mokymui buvo naudoti lètinimo sistemos užtvarinès juostos pločio $\Delta \mathrm{F}_{\mathrm{u}}$, lètinimo koeficiento $k_{\mathrm{L}}$ ties pralaidumo juostos riba ir įèjimo varžos $Z_{\mathrm{IN}}$ ties pralaidumo juostos riba vertès.

4.2 lentelèje pateikti parametrinès sintezès rezultatai, kai naudojamas daugiasluoksnis perceptronų tinklas, kurio iejjimo sluoksni sudaro trys neuronai (draudžiamosios juostos plotis $\Delta \mathrm{F}_{\mathrm{u}}$, lètinimo koeficientas $k_{\mathrm{L}}$ ir iejejimo varža $Z_{\mathrm{IN}}$ ). Išèjimo sluoksnị sudaro šeši neuronai (vienalyčių sričių ilgiai $l_{1}$ ir $l_{2}$ bei vienalyčių sričių banginès varžos $\left.Z_{1}(0), Z_{1}(\pi), Z_{2}(0), Z_{2}(\pi)\right)$. Mokymo duomenų matricos dydis $3 \times 30$, tikslo matricos dydis $6 \times 30$.

4.2 lentelè. Spiralinès lètinimo sistemos parametrinès sintezès rezultatai

Table 4.2. Results of parametric synthesis of the helical slow-wave system

\begin{tabular}{|c|c|c|c|c|c|}
\hline Variantas & $l_{1}=h_{2}, \mathrm{~mm}$ & $Z_{1}(0), \Omega$ & $Z_{1}(\pi), \Omega$ & $Z_{2}(0), \Omega$ & $Z_{2}(\pi), \Omega$ \\
\hline Etalonas & 10 & 60 & 40 & 60 & 40 \\
\hline 1 & 10 & 62,1 & 41,2 & 61,7 & 40,8 \\
\hline Etalonas & 10 & 60 & 50 & 50 & 40 \\
\hline 2 & 10 & 63,5 & 54 & 55,2 & 38,3 \\
\hline Etalonas & 10 & 60 & 50 & 50 & 30 \\
\hline 3 & 10 & 60,8 & 52,6 & 49,4 & 33,4 \\
\hline
\end{tabular}

Lyginant 4.1 lenteleje pateiktus spiralinès lètinimo sistemos pradinių elektrinių parametrų rinkinius ir parametrinès sintezès rezultatus (4.2 lentelè), pateiktus kartu su atitinkamais etaloniniais daugialaidžių linijų metodu gautais spiralinès lètinimo sistemos rezultatais, matyti, kad rezultatu svyravimas nuo etaloninių neviršija $8 \%$ paklaidos. Etalonu laikomi rezultatai, gauti sprendžiant analizės uždavinį taikant iteracinius analitinius skaičiavimo metodus, pasirinkus konkrečius geometrinių ir fizikinių parametrų rinkinius ir ieškant elektrinių spiralinès lètinimo sistemos parametrų.

\subsection{Ketvirtojo skyriaus išvados}

Remiantis atliktais tyrimais ir jų rezultatų analize galima daryti šias išvadas: 
1. Tyrimais parodyta, kad dirbtinių neuronų tinklai tinka lètinimo sistemų analizès ir sintezès uždaviniams spręsti. Taikant dirbtinių neuronų tinklus pagreitintas lètinimo sistemų analizès ir sintezès procesas bei išvengta sudètingų lètinimo sistemų matematinių modelių sudarymo.

2. Sudaryti dirbtinių neuronų tinklais paremti turintys periodinių netolygumų lètinimo sistemų automatizuoto projektavimo algoritmai leidžia paspartinti tirtų spiralinès, meandrinès ir hibridinès lètinimo sistemų sintezès ir analizès uždavinių sprendimą 465 kartus, išvengiant sistemų dispersinių lygčių išvedimo.

3. Taikant dirbtinių neuronų tinklais paremtus metodus analizės uždavinio rezultatų skirtumas nuo etaloninių daugialaidžių linijų metodu gautų rezultatų neviršija $15 \%$, o parametrinès sintezès uždavinio rezultatų skirtumas nuo etaloninių neviršija $8 \%$.

4. Esant trūkio taškams daugiasluoksnis perceptronų tinklas apmokomas prognozuoti pralaidumo juostu ribas, tuomet prognozavimas atliekamas kiekvienai pralaidumo juostai atskirai, išvengiant trūkių sričių. 


\section{Bendrosios išvados}

1. Parodyta, kad ištirti spiralinių ir meandrinių lètinimo sistemų užtvarines savybes įtakojančius rezonansinius reiškinius ir juos lemiančius veiksnius bei jų įtaką lètinimo sistemų dažninèms savybėms galima sudarytais ilgosios ir daugialaidès linijos matematiniais modeliais, taikant analitinius matricų, ilgujų ir daugialaidžių linijų metodus. Sudarytų modelių tyrimų rezultatų adekvatumas parodytas taikant specializuotų programų paketus CST Microwave Studio ${ }^{\circledR}$ ir Sonnet ${ }^{\circledR}$, kuriuose skaičiavimai vykdomi baigtinių skirtumų laiko srities ir momentų metodais.

2. Tyrimais parodyta, kad dèl periodinių netolygumų ir nuo jų atsiradusių daugkartinių atspindžių, kai fazių skirtumo kampas tarp gretimų lètinimo sistemos laidininkų itampų arba srovių arteja prie $\pi / 2$ arba $\pi$, lètinimo sistemos ịgauna užtvarinių filtrų savybių. Išvengti užtvarinių savybių pavyksta, mažinant banginių varžų kitimo išilgai laidininko santykị iki 1,3 ir didinant vienalyčių sričių ilgių santyki iki 1,5 bei mažinant nevienalytiškumo periodą, t. y. didinant nevienalyčių periodų skaičių išilgai laidininko vijos.

3. Tyrimais parodyta, kad didinant elektroninio įtaiso, turinčio kreipimolètinimo sistemą, jautrumą ir naudojant meandro formos elektrodus su plačiu centriniu laidininku bei siaurais laidininkais kraštuose, svarbu iš- 
vengti meandrinio laidininko skersinio asimetriškumo, kuris perpus susiaurina įtaiso pralaidumo juostą.

4. Naudojant hibridinę lètinimo sistemą, t. y. kraštines meandrinio laidininko sritis keičiant spiralès formos vijomis, pavyksta 1,7 karto padidinti sistemos iejjimo varžą ir lètinimo koeficientą.

5. Sudaryti dirbtinių neuronų tinklais paremti turintys periodinių netolygumų lètinimo sistemų automatizuoto projektavimo algoritmai leidžia paspartinti tirtų spiralinès, meandrinès ir hibridinès lètinimo sistemų sintezès ir analizès uždavinių sprendimą 465 kartus, išvengiant sistemų dispersinių lygčių išvedimo. Taikant dirbtinių neuronų tinklais paremtus metodus analizès uždavinio rezultatų skirtumas nuo etaloninių daugialaidžių linijų metodu gautų rezultatų neviršija $15 \%$, o parametrinès sintezès uždavinio rezultatų skirtumas nuo etaloninių neviršija $8 \%$. 


\section{Literatūra ir šaltiniai}

Alaria, M. K.; Bera, A.; Sharma, R. K.; Srivastava, V. 2010. Design and Characterization of Helix Slow Wave Structure for Ku-BAND Space TWT, Progress In Electromagnetics Research 16: 171-182.

Aziz, M. Z. A; Zainuddin, N. A.; Salleh, A.; Othman, M. A. 2012. Investigation of Dual Meander Slot to Microstrip Patch Antenna, IOSR Journal of Electronics and Communication Engineering 3: 1-6.

Bellil, W.; Amar, C. B.; Alimi, A. M. 2006. Synthesis of Wavelet Filters Using Wavelet Neural Networks, World Academy of Science, Engineering and Technology 13: $108-111$.

Bhobe, A. U. 2001. Meander Delay Line Challenge Problem: a Comparison Using FDTD, FEM and MoM, in IEEE International Symposium on Electromagnetic Compatibility 2: 805-810.

Boyle, M.; Barsanti, M.; True, R. 2012. Magnetic Interaction Between Traveling Wave Tubes and Its Effect on Performance and Reliability, in IEEE Vacuum Electronics Conference (IVEC): 155-156.

Booske, J. H.; Dobbs, R. J.; Kory, C. L.; Neil, G. R.; Park, G. S.; Park, J.; Temkin, R. J. 2011. Vacuum Electronic High Power Terahertz Sources, IEEE Transactions on Terahertz Science and Technology 1: 54-75. 
Bui, D.; Nguyen, D. K.; Ngo, T. D. 2009. Supervising an Unsupervised Neural Network, in Asian Conference on Intelligent Information and Database Systems: 307-312.

Bulja, S.; Mirshekar-Syahkal, D. 2010. Meander Line Millimetrewave Liquid Crystal Based Phase Shifter, Electronics Letters 46(11): 769-771.

Burokas, T.; Staras, S. 2008. Properties of the Retard System Models Based on the Complex Cross Section Multiconductor Lines, Electronics and Electrical Engineering 4(84): 3-8.

Burokas, T.; Štaras, S. 2004. Laikiklių ịtaka spiralinių ir meandrinių sistemų savybėms, Elektronika ir elektrotechnika 4(53): 22-27.

Burokas, T.; Štaras, S. 2005. Nevienalyčių lovelinių sistemų savybės, Elektronika ir elektrotechnika 6(62): 26-31.

Chang, W. S.; Chang, C. Y. 2012. A High Slow-Wave Factor Microstrip Structure With Simple Design Formulas and Its Application to Microwave Circuit Design, IEEE Transactions on Microwave Theory and Techniques 60(11): 3376-3383.

Chiang, M. J.; Wu, H. S.; Tzuang, C. K. C. 2008. A CMOS 3-dB Directional Coupler Using Edge-Coupled Meandered Synthetic Transmission Lines, in Microwave Symposium Digest, Conference Publication: 771-774.

CST Microwave Studio ${ }^{\circledR}$ [interaktyvus] 2013 [žiūrèta 20130107 ]. Interneto prieiga: $<$ http://www.cst.com/Content/Products/MWS/Overview.aspx $>$.

Clayton, R. P. 2008. Analysis of Multiconductor Transmission Lines: Second Edition. Hoboken, New Jersey: John Wiley \& Sons, Inc. 815 p.

Coaker, B.; Challis, T. 2008. Travell Wave Tubes: Modern Devices and Contemporary Applications, Microwave Journal 51: 32-46.

Cormack, G. D. 1993. Picosecond Pulse Generator Using Delay Lines, IEEE Transactions, Instrumentation and Measurement 42: 947-948.

$\mathrm{CPI}^{\circledR} \quad$ [interaktyvus] 2013 [žiūrèta $2013 \quad 01$ 04]. Interneto prieiga: $<$ http://www.cpii.com/product.cfm/1/19 $>$.

Cui, D.; Liu, Y.; Wu, Y.; Li, S.; Yu, C. 2011. A Compact Bandstop Filter Based On Two Meandered Parallel-Coupled Lines, Progress In Electromagnetics Research 121: 271-279.

Besoli, A. G.; Lee, G. A.; De Flaviis, F. 2005. Helical Meander Line Antenna and Its Spatial Power Combining for Circular Polarization, in Antennas and Propagation Society International Symposium 2a: 262-265.

Darwish, A.; Ezzeddine, A. 2009. Three Dimensional Transmission Lines and Power Divider Circuits, in Design \& Technology of Integrated Systems in Nanoscal Era: 184-190.

Daškevičius V.; Skudutis J.; Štaras S. 2007. Simulation and Properties of the H-Profile Meander System, Electronics and Electrical Engineering 3: 65-68. 
Daškevičius, V.; Skudutis, J. 2007. Simulation of the Inhomogeneous Meander Line, Electronics and Electrical Engineering 2(74): 37-40.

Daškevičius, V.; Skudutis, J.; Štaras, S. 2008. Simulation of Symmetrical and Asymmetrically Shielded Helical Lines, Electronics and Electrical Engineering 3(83): 3-6.

Daškevičius, V.; Skudutis, J.; Štaras, S. 2009. Simulation of the Axially Symmetrical Helical Line, Electronics and Electrical Engineering 1(89): 101-104.

Duan, Z. Y.; Gong, Y. B.; Wei, Y. Y.; Wang, W. X.; Wu, I.; Kong, J. A. 2008. Efficiency Improvement of Broadband Helix Traveling Wave Tubes Using Hybrid Phase Velocity Tapering Model, Journal of Electromagnetic Waves and Applications 22: $1013-1023$.

e2 ${ }^{\circledR}$ [interaktyvus] 2013 [žiūrèta $2013 \quad 01 \quad 04$. Interneto prieiga: $<$ http://www.e2v.com/products-and-services/rf-power-solutions/helix-twts/>.

e2v. 2008. New Generation Travelling Wave Tubes, Microwave Journal 51: 272-275.

Ergul, O.; Malas, T.; Gurek, L. 2011. Analysis of Dielectric Photonic-Crystal Problems with MLFMA and Schur-Complement Preconditioners, Journal Lightwave technology 29: 888-897.

Fakharzadeh, M.; Ramahi, O. M.; Safavi-Naeini, S.; Chaudhuri, S. K. 2008. Design and Analysis of Ultra-Miniaturized Meandering Photonic Crystals Delay Lines, IEEE Transactions on Advanced Packaging 31: 311-319.

Garg, R. 2008. Analytical and Computational Methods in Electromagnetics. Norwood. Artech House. 551 p.

Ge, L.; Wang, J. P.; Guo, Y. X. 2010. Compact Microstrip Lowpass Filtre With UltraWide Stopband, Electronics Letters 40(10): 689-691.

Glover, I. A.; Pennock, S. R.; Shepherd, P. R. 2005. Microwave Devices, Circuits and Subsystems for Communications Engineering. England, Chichester: John Wiley \& Sons. 551.

Gong, S. P.; Qu, J. R.; Hu, Y. X.; Fu, Q. Y.; Zhou, D. X. 2010. Design of Triple-Band LTCC Antenna Using Meander Line Structure for Mobile Handsets, in Microwave and Millimeter Wave Technology (ICMMT) Conference Publications: 370-372.

Gorbunova, A.; Kuznetsov, Y. 2011. Equivalent Circuit Synthesis for Microstrip Structures Design and Optimisation, in General Assembly and Scientific Symposium: 1-4.

Gorur, A.; Karpuz, C. 2007. Miniature Dual-Mode Microstrip Filters, IEEE Microwave and Wireless Components Letters 17(1): 37-39.

Gurskas, A. 1995. Baigtinių elementų metodo taikymas mikrojuostelinių daugialaidžių linijų paskirstytosioms talpoms skaičiuoti, Elektronika ir elektrotechnika 3(3): 56-60.

Gurskas, A.; Urbanavičius, V.; Martavičius, R. 2010. Evaluation of The Microstrip Lines Connectors in The Meander Delay Line Model, Electronics and Electrical Engineering 3(99): 39-42. 
Hoefer, D. G; Swanson, Jr.; Wolfgang, J. R. 2003. Microwave Circuit Modeling Using Electromagnetic Field Simulation. Artech House Publishers. 47 p.

Hsu, K. W.; Tu, W. H. 2012. Sharp-Rejection Quad-Band Bandpass Filter Using Meandering Structure, Electronics Letters 48(15): 935-937.

Imeci, T. S.; Sisman, I.; Hazar. S. T.; Demircioglu, E. 2011. 3 dB Meander Line Coupler, in Progress in Applied Computational Electromagnetics 27: 231-236.

Yahia, M.; Tao, J. W.; Benzina, H.; Abdelkrim, M. N. 2010. Ridged Waveguide Filter Optimization Using The Neural Networks and A Modified Simplex Method, International Journal of Innovation, Management and Technology 1(3): 259-263.

Ye, C. S.; Su, Y. K.; Weng, M. H.; Hung, C. Y.; Yang, R. Y. 2010. Design of the Compact Parallel-Coupled Lines Wideband Bandpass Filters Using Image Parameter Method, Progress In Electromagnetics Research PIER 100: 153-173.

Ymeci, S. T.; Sisman, I.; Hazar, S. T. Demircioglu, E. 2011. 3 dB Meander Line Coupler, in 27th Annual Review of Progress in Applied Computational Electromagnetics, Virginia: 231-236.

Yoon, S.; Besoli, A. G.; Lee, G. A.; De Flaviis, F. 2005. Helical Meander Line Antenna and Its Spatial Power Combining for Circular Polarization, IEEE Antennas and Propagation Society 2a: 262-265.

Yu, M.; Dokas, D. 2004. High Performance Helical Resonator Filters, in Microwave Conference 2: 989-992.

Kabir, H.; Wang, Y.; Yu, M.; Zhang, Q. J. 2008. Neural Network Inverse Modeling and Applications to Microwave Filter Design, IEEE Microwave Theory Tech. 56: 867-879.

Kabir, H.; Zhang, L.; Yu, M.; Aaen, P.; Wood, K.; Zhang, Q. J. 2010. Smart Modeling of Microwave Devices, IEEE Microwave magazine 11: 105-118.

Kabiri, A.; Qing, H.; Kermani, M. H.; Ramahi, O. M. 2010. Design of A Controllable Delay Line, in Advanced Packaging, IEEE Transactions 33: 1080-1087.

Kallmann, H. E. 1946. Equalized Delay lines, in Proceedings of the IRE 34: 646-657.

Kirvaitis, R. 1994. Elektrodinaminès vèlinimo linijos. Vilnius: Technika. 216 p.

Kory, C. L.; Mearini, G. T.; Malta, D.; Lueck, M.; Gilchrist, K. 2009. Applying Microfabrication to Helical Vacuum Electron Devices for THz Applications, in Vacuum Electronics Conference IVEC09: 41-44.

Krozer, V.; Zhurbenko, V. 2010. Square Helix TWT for THz Frequencies, in Infrared Millimeter and Terahertz Waves 35th International Conference Proceedings: 1-2.

Krukonis, A. 2010. Baigtinių skirtumų metodo skaičiavimo būdų tyrimas, Mokslas Lietuvos ateitis 2(1): 103-107.

Krukonis, A.; Urbanavičius, V. 2011. Investigation of Microstrip Lines Dispersion by The FDTD Method, Electronics and Electrical engineering 9(115): 51-54. 
Krukonis, A.; Urbanavičius, V. 2012. Multiconductor Microstrip Line Modelling Using FDTD Method, in EMD'2012 International Conference Proceedings 22: 60-63.

L3 communications $^{\circledR}$ [interaktyvus] 2013 [žiūrèta 201301 04]. Interneto prieiga: $<$ http://www2.1-3com.com/edd/products traveling_wave tube.htm $>$.

Liu, L.; Weng, Y. F.; Cheung, S. W.; Yuk, T. I.; Peter, T. 2012. Deep Band-Notched Characteristic Using Meander Lines for UWB Monopole Antennas, in PIERS Proceedings: 27-30.

Longbrake, M. 2012. True Time-Delay Beamsteering for Radar, in National Aerospace \& Electronics Conference of USA Proceedings: 25-29.

Malathi, P.; Kumar, R.; Patil, D. Y. 2009. Design of Multilayer Rectangular Microstrip Antenna Using Artificial Neural Networks, International Journal of Recent Trends in Engineering 2(5): 53-57.

Maloratsky, L. G. 2009. Microstrips Circuits with a Modified Ground Plane, High Frequency Electronics 1: 38-47.

Maloratsky, L. G. 2011. Using Modified Microstrip Lines to Improve Circuit Performance, High Frequency Electronics 1: 36-52.

Marchewka, C.; Donald, A.; True, R.; Hargreaves, T. 2010. A 125 Watt Ka-Band Mini Traveling Wave Tube, in IEEE Vacuum Electronics Conference (IVEC): 301-303.

Martavičius, R. 1996. Elektrodinaminès planarinès lètinimo sistemos plačiajuosčiams elektroniniams prietaisams. Vilnius: Technika. 264 p.

Meerschaert, M.; Scheffler, H. P.; Tadjeran, C. 2006. Finite Difference Methods for Two-Dimensional Fractional Dispersion Equation, Journal of Computational Physics 211: 249-261.

Meng-Ju Chiang; Hsien-Shun Wu; Tzuang, C. K. C. 2008. A CMOS 3-dB Directional Coupler Using Edge-Coupled Meandered Synthetic Transmission Lines, in IEEE MTT-S International Microwave Symposium Digest: 771-774.

Metlevskis, E.; Urbanavičius, V. 2010. Analysis of Rectangular Microstrip Structures by The Method of Moments, in 18th International Conference on Microwave, Radar and Wireless Communications MIKON-2010: 228-231.

Metlevskis, E.; Urbanavičius, V. 2011. Analysis of Charge Distribution on Rectangular Microstrip Structures, Acta Physica Polonica A Warszawa: Polish Academy of Sciences 119(4): 503-508.

Metlevskis, E.; Martavičius, R. 2012. Computer Models of Meander Slow-Wave System with Additional Shields, Electronics and Electrical Engineering 3(119): 61-64.

Michalski, J. J. 2010. Artificial Neural Networks Approach in Microwave Filter Tuning, in Progress in Electromagnetics Research 13: 173-188. 
Mikučionis, Š.; Urbanavičius, V. 2010. Investigation of Normal Modes in Microstrip Multiconductor Line Using The MoM, Electronics and Electrical Engineering 4(100): 91-94.

Mikučionis, Š.; Urbanavičius, V. 2011. Synthesis of Six-Conductors Symmetrically Coupled Microstrip Line, Operating in A Normal Mode, Electronics and Electrical Engineering 4(110): 47-52.

Ninomiya, H., Wan, S.; Kabir, H.; Zhang, X.; Zhang, Q. J. 2008. Robust Training of Microwave Neural Network Models Using Combined Global/Local Optimization Techniquesm, in IEEE MTT-S International Microwave Symposium: 995-998.

Nassar, I. T.; Weller, M. 2011. An Electrically Small Meandered Line Antenna with Truncated Ground Plane, in IEEE Radio and Wireless Symposium: 94-97.

Navakauskas, D. 2000. Skaitmeninio signalu apdorojimo priemonès. Dirbtiniu neuronu tinklai. Vilnius: Technika, $51 \mathrm{p}$.

$\mathrm{NEC}^{\circledR}$. [interaktyvus] 2013 [žiūrèta $2013 \quad 01$ 04]. Interneto prieiga: $<\underline{\text { http://www.nec.co.jp/press/en/9906/0701.html }>\text {. }}$

Niklas, W. F.; Wimpffel, J. 1958. Oscilloscope Tube with Traveling Wave Deflection System and Large Field of View, The Journal of The British IRE 18: 653-660.

Nvidia $^{\circledR}$ [interaktyvus] 2012 [žiūrèta $2012 \quad 11$ 30]. Interneto prieiga: <http://www.nvidia.com/object/cuda_home_new.html $>$.

Pomarnacki, R., Gurskas, A., Urbanavičius, V. 2012. Topology Synthesis of the MultiTapped Meander Delay Line Using Monte Carlo Method, Electronics and Electrical Engineering 18(8): 41-44.

Pomarnacki, R.; Urbanavičius, V. 2009. Parallel System for The Analysis of Meander Delay Line, in the International Conference "IC-SPETO 2009": 53-54.

Powers, S. D.; Cruz, J. M. 2000. Measurements and Modelling of Delay Lines on Printed Circuit Boards. Sun Microsystems: $21 \mathrm{p}$.

Radway, M. J.; Filipovic, D. S. 2012. Four-Armed Spiral-Helix Antenna, IEEE Antennas and Wireless Propagation Letters 11: 338-341.

Rizzoli, V.; Costanzo, A.; Masotti, D.; Lipparini, A.; Mastri, F. 2004. Computer-Aided Optimization of Nonlinear Microwave Circuits with The Aid of Electromagnetic Simulation, IEEE Trans. Microwave Theory Tech. 52(1): 362-377.

Schreurs, P.; Verspecht, J.; Vandenberghe, S.; Vandamme, E. 2002. Straightforward and Accurate Nonlinear Device Model Parameter-Estimation Method Based on Vectorial Large-Signal Measurements, in IEEE Trans. Microwave Theory Tech. 50(10): 2315-2319.

Sensiper S. 1951. Electromagnetic Wave Propagation on Helical Conductors. Massachusetts Institute of Technology technical report $114.126 \mathrm{p}$. 
Shugurov, V.; Nickelson, L. 2005. Singular Integral Equation's Methods For The Analysis Of Microwave Structures. V.S.P.: Intl Science. 330 p.

Singh, J.; Singh, A. P.; Kamal, T. S. 2011. Design of Circular Microstrip Antenna Using Artificial Neural Networks, in Proceedings of the World Congress on Engineering 2(1): 9-12.

Sonnet $^{\circledR} \quad$ [interaktyvus] 2013 [žiūrèta $2013 \quad 01$ 07]. Interneto prieiga: $<$ http://www.sonnetsoftware.com/products/sonnet-suites/how-em-works.html $>$.

Srivastava, V. 2008. THz Vacuum Microelectronic Devices, in Journal of Physics: Conference Series 114: 1-10.

Sun, C. X.; Feng, L. Y.; Liu, X. Y.; Zheng, H. X. 2012. Compact Dual-Mode Filter Using Meander Shorted Stub Loaded Resonators, Progress In Electromagnetics Research Letters 30: 195-203.

Wang, J.; Xu, L. J.; Zhao, S.; Guo, Y. X.; Wu, W. 2010. Compact Quasi-Elliptic Microstrip Lowpass Filter with Wide Stopband, Electronics Letters 46: 1384-1385.

Watanabe, K.; Sekine, T.; Takahashi, Y. 2009. A FDTD Method for Nonuniform Transmission Line Analysis Using Yee's-Lattice and Wavelet Expansion, in IEEE MTTS International Signal Integrity and High-Speed Interconnects Workshop: 83-86.

Wei, D.; Zeng, H.; Yu, Z. 2012. Compact Branch-Line Coupler Using Composite Right/Left-Handed Transmission Lines With Novel CSSRR, in Consumer Electronics, Communications and Networks CECNet2012 Conference Publications: 218-221.

Sadiku, N. O. 2009. Numerical techniques in electromagnetics with MATLAB. CRC press. $648 \mathrm{p}$.

Singh, A.; Singh, K.; Kumar, S.; Kumar, T. 2008. Empirical Relation for Designing the Meander Line Antenna, in Recent Advances in Microwave Theory and Application: 695-697.

Sharma, RK.; Bera, A.; Srivastava, V. 2009. Thermal and Structural Analysis of Electron Gun Assembly for A C-band 60W Space TWT, International Journal of Microwave and Optical Technology 4: 309-314.

Soluch, W. 2012. Scattering Matrix Approach to SHAPM Delay Line with Long Interdigital Transducers on BT-Cut Quartz, IEEE Ultrasonics, Ferroelectrics and Frequency Control 59: 2576-2579.

Štaras, S, Burokas, T. 2003. Nevienalyčių spiralinių sistemų savybės, Elektronika ir elektrotechnika 1(43): 17-20.

Staras, S. 2005. Simulation and Properties of the Shielded Twined Helical Deflecting System, in IEEE Transactions on Electron Devices 52: 1222-1225.

Štaras, S.; Daškevičius, V.; Skudutis, J. 2006. Simulation and Properties of The QuasiSymmetrical Helical Structure, in IEEE Transactions on Electron Devices, New York 53(10): 2649-2654. 
Štaras, S. 2008. Ivadas i skaitmeninius elektrodinamikos metodus ir ju taikyma. Vilnius: Technika. $186 \mathrm{p}$.

Štaras, S.; Burokas, T. 2006. Frequency-Dependent Distortions of Pulses in The Traveling-Wave Cathode-Ray Tubes, in 16th International Conference on Microwaves, Radar and Wireless MIKON-2006 Kraków: 812-815.

Štaras, S. Martavičius, R.; Skudutis, J.; Urbanavičius, V.; Daškevičius, V. 2010. Plačiajuosčiu lètinimo ịtaisu modeliavimas ir taikymas: monografija. Vilnius: Technika. 442 p.

Štaras, S.; Martavičius, R.; Skudutis, J.; Urbanavičius, V.; Daškevičius, V. 2012. WideBand Slow-Wave Systems: Simulation and Applications. CRC Press. 460 p.

Штарас, С.; Вайнорис 3.; Мартавичюс Р.; Скудутис, Ю.; Станкунас, Й. 1993. Широкополосные тракты электронно-лучевых трубок бегущей волны: Монография. Вильнюс: Техника. 359 с.

Тараненко, 3. И.; Трохименко, Я. К. 1965. Замедляющие системы. Киев. 307 с.

Teledyne Mec ${ }^{\circledR}$. [interaktyvus] 2013 [žiūrèta 2013 01 04]. Interneto prieiga: $<$ http://www.teledyne-mec.com/products/Technical description.aspx $>$.

Thales $^{\circledR} \quad$ [interaktyvus] 2013 [žiūrèta 2013 01 04]. Interneto prieiga: $<$ http://www.thalesgroup.com/Portfolio/Security/CS TWTs_for_Space_K and Ka ba nds $/>$.

Toccafondi, A.; Braconi, P. 2006. Compact Load-Bars Meander Line Antenna for UHF RFID Transponder, in IEEE Antennas and Propagation Proceedings: 1-4.

Tomar, G. S.; Kushwah, V. S.; Saxena, S. 2010. Design of Microstrip Filters Using Neural Network, in Second International Conference on Communication Software and Networks: 568-572.

$\mathrm{TMD}^{\circledR} \quad$ [interaktyvus] 2013 [žiūrèta 2013 01 04]. Interneto prieiga: $<$ http://www.tmd.co.uk/products/microwave tubes/index.asp $>$.

Urbanavičius, V. 1995. Meandriniu vélinimo liniju analize ir projektavimas, Daktaro disertacija. VTU, Vilnius. $166 \mathrm{p}$.

Urbanavičius, V.; Gurskas, A.; Martavicius, R. 2009. Simulation of the Meander Delay Line Using The Hybrid Method, Electronics and Electrical Engineering 2(90): 3-6.

Urbanavičius, V.; Mikučionis, Š.; Martavicius, R. 2007. Model of the Coupled Transmission Lines with a Non-Uniform Dielectric, Electronics and Electrical Engineering 5(77): 23-28.

Vainoris, Z. 2004. Bangu elektronikos pagrindai: vadovèlis. Vilnius: Technika. 513 p.

Вайнорис, 3. А.; Кирвайтис, Р. И.; Штарас, С. С. 1986. Электродинамические задерживающие и отклоняющие системы. Вильнюс: Мокслас. 266 с.

Xavier, C. C.; Motta, C. C. 2009. Modeling of A Gridded Electron Gun for Traveling Wave Tubes, in Pulsed Power Conference Publications: 537-541. 
Zhou, G.; Su, L.; Jin, D.; Zeng, L. 2008. A Delay Model for Interconnect Trees Based on ABCD matrix, in Design Automation Conference ASPDAC Proceedings: 510-513.

Zhu, Y.; Zuegel, J. D.; Marciante, J. R.; Wu, H. 2007. Radio Frequency Integrated Circuits RFIC, in IEEE Symposium: 35-38. 



\section{Autoriaus publikacijų disertacijos tema sąrašas}

\section{Straipsniai recenzuojamuose mokslo žurnaluose}

Katkevičius, A. 2012. Mikrobangų ittaisų modeliavimas, taikant dirbtinių neuronų tinklus, Mokslas - Lietuvos ateitis 4(1): 81-84. ISSN 2029-2341. (ICONDA, Gale®, ProQuest, EBSCOhost, IndexCopernicus).

Katkevičius, A.; Mališauskas, V.; Plonis, D.; Serackis, A. 2012. Calculations of Characteristics of Microwave Devices Using Artificial Neural Networks, Przeglad elektrotechniczny 88(1a): 281-285. ISSN 0033-2097. (ISI Web of Science).

Katkevičius, A. Štaras, S. 2011. Analysis of Rejection Properties of Meander Systems, Electronics and Electrical Engineering 2(108): 19-22. ISSN 1392-1215. (ISI Web of Science).

Štaras, S.; Katkevičius, A. 2010. Properties of Helical Structures Containing Periodical Inhomogeneities, Electronics and Electrical Engineering 3(99): 49-52. ISSN 13921215. (ISI Web of Science).

Daškevičius, V.; Skudutis, J.; Katkevičius, A.; Štaras, S. 2010. Simulation and Properties of The Wide-Band Hybrid Slow-Wave System, Electronics and Electrical Engineering 8(104): 43-46. ISSN 1392-1215. (ISI Web of Science). 
Katkevičius, A. 2010. Linijų su periodiniais netolygumais savybių tyrimas, Mokslas Lietuvos ateitis 2(1): 108-111. ISSN 2029-2341. (Inspec).

\section{Straipsniai kituose leidiniuose}

Katkevičius, A.; Martavičius, R. 2012. Automated Synthesis Method for Inhomogeneous Delay Systems Using Artificial Neural Networks, in EMD'2012 International Conference on Electromagnetic Disturbances Proceedings: 43-46. ISSN 1822-3249. ISBN 9786094572609.

Štaras, S.; Katkevičius, A. 2010. Analysis of Helical Systems Containing Periodical Inhomogeneities, in 18th International Conference on Microwave, Radar and Wireless Communications (MIKON-2010) Proceedings: 391-394. ISBN 9789955690207.

Katkevičius, A.; Štaras, S. 2009. Simulation of Structures Containing Periodical Inhomogeneities, in EMD'2009 International Conference on Electromagnetic Disturbances Proceedings: 83-86. ISBN 9788360200728. 


\section{Priedai}

\section{A priedas. Eksperimentinès sistemos struktūrinè schema}

Eksperimentiniai tyrimai atlikti remiantis žemiau pateikta struktūrine schema (A1 pav.).

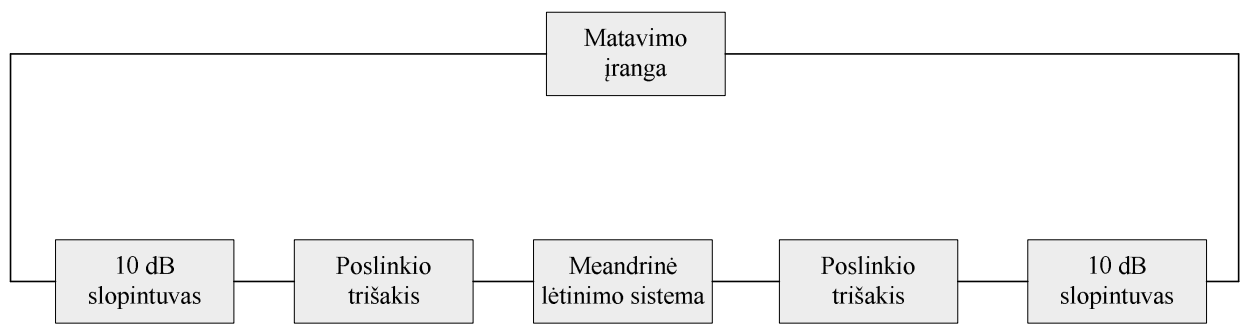

A1 pav. Lètinimo sistemų eksperimentinių tyrimų struktūrinè schema

Fig. A1. Structural scheme of experimental investigation of slow-wave systems

Tirta meandrine lètinimo sistema (1.7 pav.), kurios matmenys: $h=1,5 \mathrm{~mm}$; $t=35 \mu \mathrm{m} ; w=0,4 \mathrm{~mm} ; s=0,6 \mathrm{~mm} ; 2 A=10 \mathrm{~mm}$. Taikyta pagrindo medžiaga stiklo tekstolitas FR4 $\varepsilon_{\mathrm{r}}=4,4$. 


\section{B priedas. Meandrinès lètinimo sistemos eksperimento rezultatai}

Meandrinès lètinimo sistemos signalo atspindžio nuo iejjimo $S_{11}$ ir signalo perdavimo koeficiento $S_{21}$ matavimų rezultatai (B1 pav.).

Data: $2013 \quad 322$

FREQUENCY RANGE: $0.979-1230.000 \mathrm{MHz}$

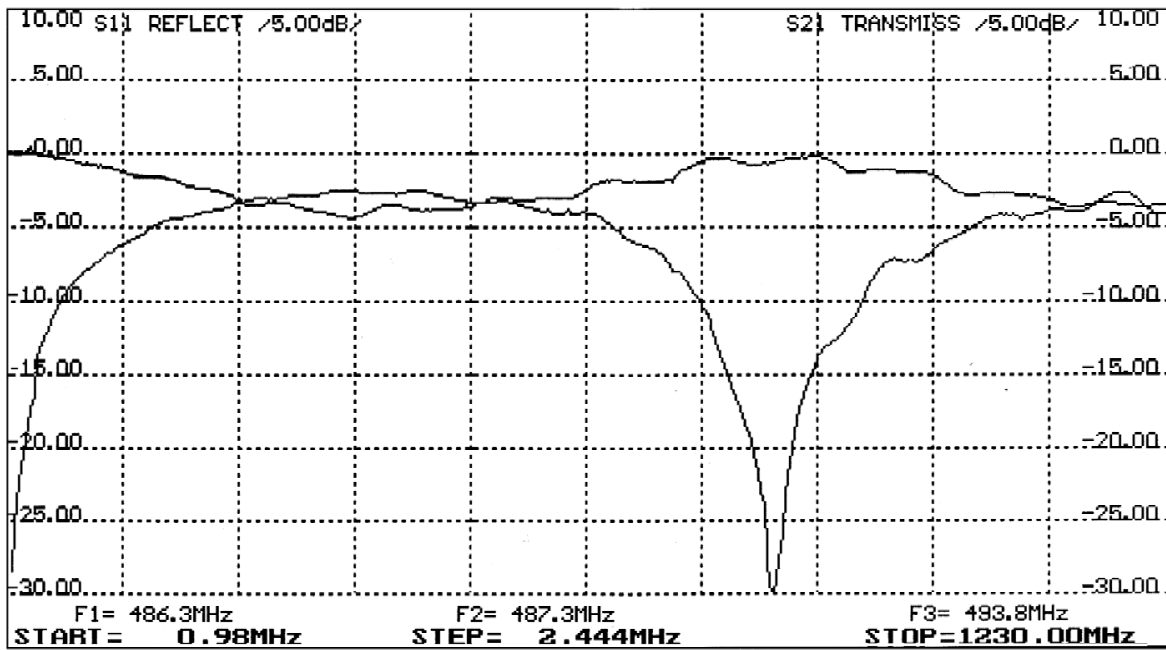

$\begin{array}{ccccc}\text { FREQUENCY } & \text { s21 }[\mathrm{dB}] & \mathrm{s} 11[\mathrm{~dB}] & \mathrm{s} 11[\mathrm{VSWR}] & \text { DEG }(\mathrm{s} 21) \\ \mathrm{f} 1=494.250 & -3.78 & -3.31 & 5.31 & -118.4 \\ \mathrm{f} 2=494.250 & -3.78 & -3.31 & 5.31 & -118.4 \\ \mathrm{f} 3=501.250 & -3.65 & -3.38 & 5.20 & -120.8\end{array}$

B1 pav. Meandrinès lètinimo sistemos $\mathrm{S}$ parametrų eksperimentiniai rezultatai

Fig. B1. Experimental results of S parameters of meander slow-wave system 
Andrius KATKEVIČIUS

\section{SPIRALINIỤ IR MEANDRINIỤ LĖTINIMO SISTEMŲ \\ DAŽNINIŲ SAVYBIŲ TYRIMAS}

Daktaro disertacija

Technologijos mokslai,

elektros ir elektronikos inžinerija (01T)

INVESTIGATION OF FREQUENCY PROPERTIES OF HELICAL AND MEANDER SLOW-WAVE SYSTEMS

Doctoral Dissertation

Technological Sciences,

Electrical and Electronic Engineering (01T) 